\title{
EGOLOGY OF THE
}

C O Y O T E

I N THE YELLOW TONE

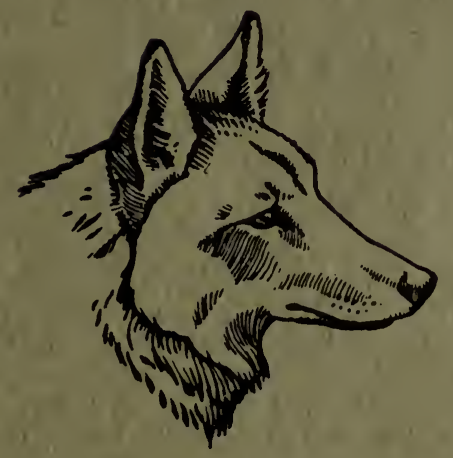

FAUNA OF THE NATIONAL PARKS OF THE UNITEDSTATES - - - BULLETIN NO. 4

UNITED STATES DEPARTMENT OF THE INTERIOR NATIONAL PARK SERVICE 
A. Dean and Jean M. Larsen

Yellowstone Park Collection

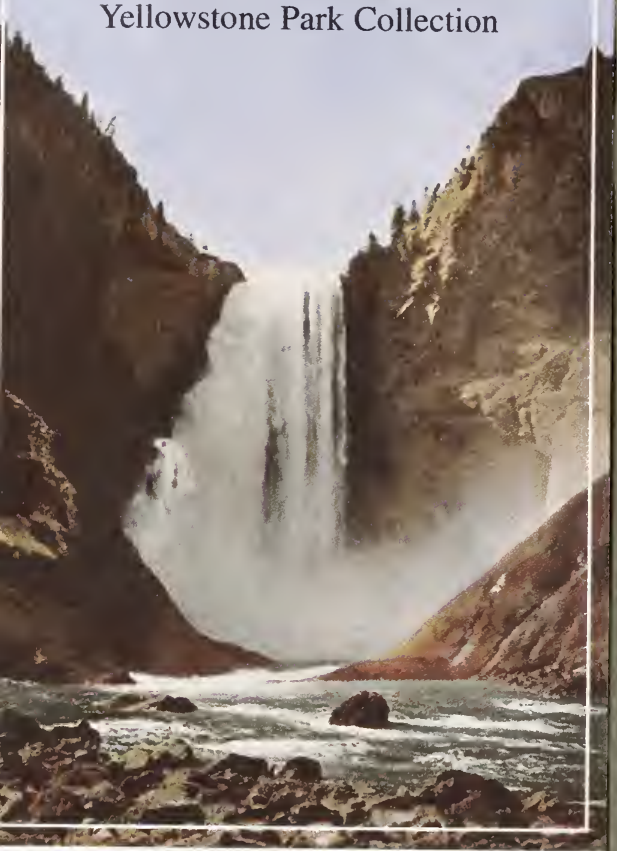

QL $737 . C 22 \quad$ M76 1940

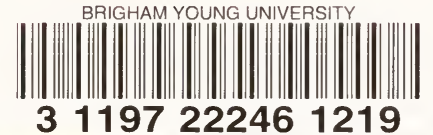




\title{
Ecology of the Coyote
}

IN THE YELLOWSTONE

\author{
By \\ ADOLPH MURIE
}

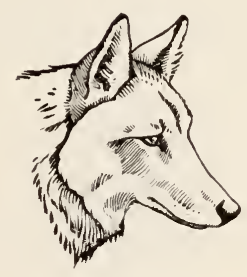

FAUNA SERIES NO. 4, 1940

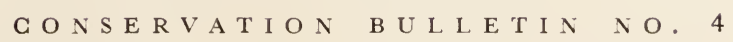

UNITED STATES GOVERNMENT PRINTING OFFICE WASHINGTON, D. C. 


\section{UNITED STATES}

\section{DEPARTMENT OF THE INTERIOR}

Harold L. Ickes, Secretary

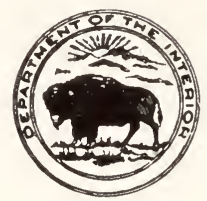

NATIONAL PARK SERVICE

Arno B. Cammerer, Director

For sale by the Superintendent of Documents Washington, D. C., Price 30 cents 


\section{Contents}

FOREWORD

CHAPTER I. INTRODUCTION

Location and general character of area . . . . . . . . . 1

Early wildlife conditions in Yellowstone . . . . . . . . . 1

Comparison of the primitive and present wildlife status . . . 8

Predator control . . . . . . . . . . . . . . . . . . 11

CHAPTER II. POPULATION AND MORTALITY

Numbers of coyotes . . . . . . . . . . . . . . 17

Movements of coyotes out of park . . . . . . . . . 18

Coyote mortality and natural controls . . . . . . . 20

CHAPTER III. HABITS

Behavior at carrion . . . . . . . . . . . . 30

Caching . . . . . . . . . . . . . . . 32

Coyote-raven relationships . . . . . . . . . . . . 33

Coyote-magpie relationships . . . . . . . . . . 36

Family hunting ground . . . . . . . . . . 36

Sociability . . . . . . . . . . . . . . . . 36

Play . . . . . . . . . . . . . . . . . . . . 38

Swimming . . . . . . . . . . . . . . 38

Limitations on travel . . . . . . . . . . . . . 38

Tolerance of humans . . . . . . . . . . . . . . 38

CHAPTER IV FOOD

Study technique . . . . . . . . . . . . . . 40

Items in the coyote diet . . . . . . . . . . . . 42

CHAPTER V. ELK IN RELATION TO COYOTES

Elk as coyote food . . . . . . . . . . . . . . . . 46

Maternal protection . . . . . . . . . . . . 51

Calf survival, 1937 . . . . . . . . . . . . . . 55

Status of elk . . . . . . . . . . . . . 57 


\section{Contents}

CHAPTER VI. MULE DEER IN RELATION TO COYOTES

Winter range

Deer as coyote food . . . . . . . . . . . . . . 58

General condition of deer, winter of 1937-38 . . . . . 59

Deer mortality, winter of $1937-38$. . . . . . . . . 61

Fawn survival . . . . . . . . . . . . . . . 66

Loss of fawns . . . . . . . . . . . . . . . . . 71

Coyote method of hunting fawns . . . . . . . . . . . 78

Coyote predation correlated with range conditions . . . . . 80

Deer-coyote behavior . . . . . . . . . . . . . . . . . 82

Status of deer . . . . . . . . . . . . . . . . . . 84

CHAPTER VII. ANTELOPE IN RELATION TO COYOTES

Winter range . . . . . . . . . . . . . . . . . 87

Spring activities . . . . . . . . . . . . . . . . . . . 89

Maternal protection . . . . . . . . . . . . . . . 90

Relationships of bucks to does and fawns . . . . . . . . 94

Fawn survival . . . . . . . . . . . . . . . . . 94

General condition of antelope . . . . . . . . . . . . 98

Antelope deaths . . . . . . . . . . . . . . . . . 99

Antelope-coyote relationships . . . . . . . . . . . 100

Status of antelope . . . . . . . . . . . . . . 101

CHAPTER VIII. BIGHORN IN RELATION TO COYOTES

Distribution and numbers . . . . . . . . . . . . 103

General condition of bighorn . . . . . . . . . . . . 104

Bighorn deaths . . . . . . . . . . . . . . . . 106

Lamb survival . . . . . . . . . . . . . . 107

Lamb-ewe relationships . . . . . . . . . . . . . 112

Bighorn-magpie relationships . . . . . . . . . . . . 112

Bighorn-coyote relationships . . . . . . . . . . . 113

Status of bighorn . . . . . . . . . . . . . . 114

CHAPTER IX. OTHER LARGE MAMMALS IN RELATION TO COYOTES

Bison . . . . . . . . . . . . . . . . . . 117

Moose . . . . . . . . . . . . . . . . 117

Domestic cow . . . . . . . . . . . . . . . . 118

Black bear . . . . . . . . . . . . . . . . . 118

Coyote . . . . . . . . . . . . . . . . . 118

Carcass fragments in coyote diet . . . . . . . . . . . . . 118 


\section{Contents}

CHAPTER X. SMALL MAMMALS IN RELATION TO COYOTES

Field mouse

Pocket gopher

Snowshoe hare

Marmot

Muskrat

Ground squirrel

White-tailed jackrabbit

Porcupine

Deer mouse

Pine squirrel . . . . . . . . . . . . . 126

Beaver . . . . . . . . . . . . . . . 126

Cottontail rabbit . . . . . . . . . . . . . . . . 127

Miscellaneous small mammals . . . . . . . . . 127

CHAPTER XI. BIRDS IN RELATION TO COYOTES

Ducks

Canada goose

Trumpeter swan

Richardson grouse . . . . . . . . . . . . . 140

Ruffed grouse . . . . . . . . . . . . . . . 141

Other bird remains . . . . . . . . . . . . 141

CHAPTER XII. MISCELLANEOUS ITEMS OF DIET

\section{Insects}

Snakes, fish, and snails

Vegetable matter

Other items 
Digitized by the Internet Archive in 2014 


\section{Illustrations}

A TYPIGAL YellowSTONE COYOTE . . . . . . . . Frontispiece

Figure

Page

$\begin{array}{lll}1 & \text { WEAKENED COYOTES EASILY CAPTURED AT TOWER FALLS · · } & 150 \\ 2 & \text { DEAD COYOTE FOUND NEAR YELLOWSTONE LAKE RANGER STATION . } & 150\end{array}$

3 A COYOTE WHICH RECOVERED FROM SICKNESS WHILE IN CAPTIVITY

4 A COYOTE AT AN ELK CARGass CHALlenges THE APPROAGH OF ANOTHER

152

5 MAGPIE RETURNING TO AN ELK GARGASS AFTER GAGHING A MORSEL OF MEAT . . . . . . . . . . . . . 152

6 COYOTES AND MAGPIES FEEDING TOGETHER ON ELK CARCASS • 153

7 SKETCH OF COYOTE AND RAVENS AT PLAY . . . . . . . . . 154

8 WEAKENED GOW ELK GROSSING MADISON RIVER . . . . . 155

9 COW ELK OFTEN BECOME VERY THIN IN THE SPRING . . . . 156

10 A WEAK CALF ELK, FALLEN ON ITS SIDE . . . . . . . . . 157

11 ELK CARGASS UPON WHICH COYOTES REGENTLY HAD FED . • 157

12 IN 1938 THERE WAS MORE ELK GARRION THAN THE COYOTE COULD EAT . . . . . . 158

13 ELK GALVES, DEAD AT BIRTH, FURNISH CARRION FOR COYOTES • 159

14 A VERY YOUNG ELK CALF ALLOWS ITSELF TO BE PETTED • • 160

15 A COW ELK TEACHES HER GALF TO FOLLOW . . . . . . . . 161

16 BROWSE LINE ON DOUGlaS FIR . . . . . . . . . . . . . 161

17 DEER RANGE- ON GARDINER RIVER BELOW LAVA GREEK . . . 162

18 A THIN FAWN . . . . . . . . . . . . . . . 163

19 FAWN BROWSING ON SAGEBRUSH . . . . . . . . . . . . . 164

20 DEAD FAWN, SHOWING INFESTATION OF NOSE FLY LARVAE • • 165

21 A SICK OLD DOE, AFTER A HARD WINTER . . . . . . . . . 166

22 MULE DEER BUCKS Fighting . . . . . . . . . . . . . . 167

23 BUCK KILlED IN A FIGHT WITH ANOTHER . . . . . . . . 168

24 BAND OF DEER NEAR NORRIS . . . . . . . . . . . . 169

25 FAWNS FEEDING ON GREASEWOOD . . . . . . . . . . . . 170

26 CEDAR HEAVILY BROWSED BY DEER . . . . . . . . . . . . 171

27 A FAWN SO WEAK THAT IT COLLAPSED AFTER A SHORT CHASE - 172

28 ROCKY TERRAIN IN WHICH DEER MAY BECOME GRIPPLED • . 173

29 AN OLD DOE, ALMOST TOO WEAK TO RISE . . . . . . . . . 174 


\section{Illustrations}

Figure

30 THE SAME DOE STAGgered INTO THE GARDINER RIVER, FROM WHICH SHE COULD NOT RISE . . . . . . . . . . . . . . 175

31 NEWLY BORN ANTELOPE BLEND WELL WITH THEIR SURROUNDINGS • 175

32 an antelope doe With her two fawns . . . . . . . . 176

33 A CRippled bUCK ANtelope . . . . . . . . . . . . . . 176

34 ANTELOPE RANGE SHOWING SAGEBRUSH KILLED BY OVERBROW'ING . . . . . . . . . . . . . . . . . 177

35 FENCED PLOT, SHOWING CONTRAST BETWEEN GRAZED AND UNGRAZED RANGE, GAME RANCH . . . . . . . . . . . . 178

36 HEAVILY BROWSED AND LIGHTLY BROWSED SAGEBRUSH ON OPPOSITE SIDES OF AN OLD FENCE LINE . . . . . . . . . . . 179

37 BIGHORN RAM HEAVILY INFESTED WITH SCAB . . . . . . 180

38 A SICK OLD RAM WHICH DIED SOON AFTER BEING PHOTOGRAPHED . 181

39 MAGPIE PERChed ON A BIGHORN EWE . . . . . . . . . . 181

40 BIGHORN AND ANTElOPE ON MOUNT EVERTS . . . . . . . . 182

41 BIGHORN FEEDING ON CLOSELY GRAZED ELK RANGE . . . . 183

42 FENCED PLOT, SHOWING GRAZED AND UNGRAZED RANGE, MOUNT EVERTS . . . . . . . . . . . . . . . . 184

43 A BIGHORN LAMB PAWING throvgh SNOW TO OBTAIN FOOD . 185

44 WATER hOLE IN WHICH A BUFFALO WAS BOGGED AND DROWNED . 186

45 BLACK BEAR, TOWER FAlls . . . . . . . . . . . . . 187

46 TRACKS IN THE SNOW SHOWING WHERE COYOTES HUNTED MICE . 188

47 SKetch of COYOte CAtChing mouse . . . . . . . . . . . . 189

48 SAgebrush Killed by MOUSE Girdling, lamar VAlley . . . 190

49 SAgebrush heAVILy PRUNed by pocket GOPHers . . . . . 191

50 GROUND SQUIRREL EMERGING THROUGH THE SNOW IN EARLY SPRING . . . . . . . . . . . . . . . . . . . . . . . 192

51 THE JACKRABBIT IS SOMETIMES COYOTE FOOD . . . . . . . 193

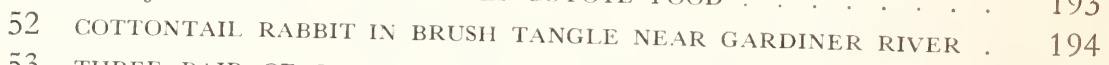

53 THREE PAIR OF CANADA GEESE AT ELK PARK . . . . . . . 195

54 Blue grouse, teton NAtionai fOREST . . . . . . . . . . 196

55 MORMON CRICKET, A FOOD ITEM RELISHED BY COYOTES . . . 197

56 COYOTE SONG . . . . . . . . . . . . . . . . . . . . . . 198

MAP OF YELLOWSTONE NATIONAL PARK . . . . . . . . . . . . 199 


\section{FOREWORD}

$\mathrm{T}$

HE SUBJECT of predator-prey relationships is one of the more complex and difficult problems in the relatively new art of wildlife conservation, and is of paramount importance in any natural area, such as national parks, from which human influence is largely excluded. During the past decade special attention has been given to the role of predators, particularly coyotes, in all of the national parks of the United States. In Yellowstone National Park it was believed for many years that control of coyotes was necessary in order to preserve the antelope, bighorn, mule deer, and other ungulates. This opinion persisted even after control had been discontinued in the spring of 1935 , in conformity with the Service policy that ". . . no native predator shall be destroyed on account of its normal utilization of any other park animal, excepting if that animal is in immediate danger of extermination... ." (Wright, Dixon, Thompson, 1933, p. 47). Sentiment favoring coyote control became so strong that in March 1937, a thorough scientific study of the coyote in Yellowstone and its relation to all species upon which it feeds was authorized, in accord with the following statement of National Park Service wildlife policy, quoted from the previous reference: ". . . no management measure or other interference with biotic relationships shall be undertaken prior to a properly conducted investigation."

Field studies were begun on May 1, 1937, and continued with minor interruptions until March 7, 1939. Approximately 14 months were spent in field and laboratory study exclusive of time devoted to writing the account here published. The study represents a survey of conditions over a period of about 2 years.

$I$ wish to express my appreciation to Arno B. Cammerer, Director of the National Park Service, for making it possible to carry on the study, and to Regional Director Thos. 7. Allen, Fr., and Associate Regional Director Paul $V$. Brown for arranging administrative routine so as to allow me time to complete the field work and write up the results. H. C. Bryant, now Public Works Administration Consultant, Region IV, and Carl P. Russell, Victor H. Cahalane, and C. C. Presnall, all of the Branch of Research and Information, have supported the study in many ways and have been a source of constant encouragement. In the field I received cooperation and many courtesies from various members of the Yellowstone National Park staff. Superintendent Edmund B. Rogers, who is interested in furthering research, supplied various facilities for the work, including access to the numerous annual and monthly 


\section{Foreword}

reports, Nature. Notes, and other official documents referred to throughout this bulletin. The brief mention of rangers and naturalists made in the text does not begin to measure the extent of their help and cooperation. I feel specially grateful to Ranger David D. Condon for the use of valuable observations made by him the winter before I began my study as well as during the progress of the study; to Assistant Park Naturalist Frank Oberhansley with whom I spent much time in the field and who worked with me on certain phases of the study; and to Rangers Rudolf Grimm and Walter Gammill who contributed many interesting observations and assistance. Arthur Olson, district ranger of the Absaroka National Forest, Gardiner, Mont., supplied me with helpful information on game conditions in the area under his jurisdiction. I also wish to express my appreciation to John Sieker, formerly supervisor of Shoshone National Forest, for opportunity to join his party on a week's field trip in the forest, where I was able to compare conditions with those in Yellowstone National Park. O. 7. Murie of the Bureau of Biological Survey helped in many ways, and Martin Murie assisted in the field work during one summer.

Jackson, Wyo.

Adolph Murie.

April 2, 1939. 



\section{Chapter I}

\section{INTRODUCTION}

\section{LOCATION AND GENERAL CHARACTER OF AREA}

Y

ELLOWSTONE National Park lies in northwestern Wyoming and takes in narrow strips of Montana and Idaho. It embraces about 3,500 square miles of mountainous and plateau country, volcanic in origin. Yellowstone Lake, near the center of the park, is surrounded by broken and rolling country sometimes called the central plateau, having an average altitude of 8,000 feet above sea level. This central plateau is bordered by mountain ranges reaching an altitude of about 10,000 feet. The north side of the park is lower, varying from about 5,300 feet near Gardiner to 6,500 feet at the Buffalo Ranch on the Lamar River. This area, along the Yellowstone and Lamar Rivers, receives less snowfall than the more elevated interior and constitutes the main winter big game range in the park.

A large part of the park is covered with lodgepole pine, but Douglas fir and spruce are common species, and whitebark pine is found at high altitudes. Open grassland is common on the high slopes and throughout the low northern area, interspersed with sagebrush in the latter locality. Small meadows occur abundantly all over the park. The Upper Sonoran Zone reaches into the park at Gardiner. Most of the park is in the Canadian Zone and the Hudsonian and Arctic-Alpine Zones are also represented. The general character of the flora and fauna of Yellowstone National Park can be secured from Bailey (1930) and Skinner (1927).

North of Yellowstone National Park lies the Absaroka National Forest and the long open valley of the Yellowstone River; to the east is the rough wilderness of the Shoshone National Forest; to the south is the Teton National Forest and the Grand Teton National Park embracing the beautiful wild Jackson Hole country; to the west lies the Gallatin and Targhee National Forests. Yellowstone National Park is surrounded by a number of wilderness areas, a fact which is important in the preservation of rare carnivores within its boundaries.

\section{EARLY WILDLIFE CONDITIONS IN YELLOWSTONE}

Plans, policies, attitudes, scientific interpretations, and hopes in regard to the wildlife in an area are contingent on the relationships between its present 


\section{Fauna of the National Parks of the United States}

and its primitive status. If present conditions differ widely from the primitive, then we may have an unnatural association of animals; the animals may be existing by recently acquired habits, they may be subjected to new predators, or to the old predators in areas of strange physiographic and floral features to which they are not adjusted. If present conditions are in the main similar to the primitive then the relationships are perhaps deeper, more stable, more significant, and represent the results of a long process of adjustment. To arrive at the primitive picture I have perused some of the early literature and compared the experiences of the early travelers with my own experiences in the mountains. Since my conclusions are contrary to those generally accepted it has seemed desirable to give briefly some support for them.

It is frequently said (Rush (1932), Skinner (1927), and others) that in the early days game was scarce in the mountains; that it is much more abundant there now than it was originally; that game migrated to the mountains about 1880; and that game was more abundant on the plains than in the mountains. The last statement seems true; the preceding ones lack evidence for their support, because it is probable that the mountain animals were the only ones to escape destruction; and the first two conclusions appear untenable in the light of evidence found in early reports and journals.

In analyzing the statements made by early explorers some points must be kept in mind. First, negative evidence must yield to positive evidence because failure to report game does not disprove its abundance. Difficulty in finding game where it is known to be abundant is a common experience. Acting Superintendent F. A. Boutelle in a supplement to the 1889 Yellowstone Annual Report makes the statement: "Visitors are sometimes a little incredulous as to the great number of large game animals in the park and complain that they have seen nothing." In more recent years I heard a superintendent make a similar remark in regard to the abundance of elk in Yellowstone. While studying elk in Teton National Forest south of Yellowstone in 1928 where hundreds of elk were summering, there were periods, especially in late summer, when the elk were more in the woods and we had difficulty finding the animals. In 1938 I heard an old-timer, familiar with all details of the Jackson Hole elk country, say that he had been out on the elk summer range for more than a week to photograph them and had hardly found an elk. It is not at all surprising to me to read of early hunting parties failing to shoot game in good mountain game country. Some other factors operating in varying degrees to give the impression that game was originally scarce in the mountains are: (1) game in summer was largely at high elevations away from traveled routes; (2) game was often much 


\section{Ecology of the Coyote in the Tellowstone}

hunted along the routes and may have been locally scarce; (3) large parties were noisy, resulting in game being scared away; (4) large parties needed a big supply of game and at regular intervals, so it was not unexpected that they should run out of food; (5) although game was no doubt more plentiful in the plains country than in the mountains the contrast was accentuated by wider visibility and easier hunting on the plains; (6) as in present-day journals, game was often referred to only casually, so all game was not necessarily listed; and (7) some habitats in the mountains, such as the dense lodgepole pine, are poor in game today, and the naturalist of the 1872 Hayden party traveled through Yellowstone largely in this habitat and not through the best summer game country. So much for explaining the impression sometimes obtained that game was scarce in the mountains.

One of the most fascinating books on early western travel is the Journal of a Trapper by Osborne Russell. It covers several trips made by the author into Yellowstone between 1834 and 1843. The diary is exceptionally well written and the author was apparently a careful and truthful observer. In the following, the localities given in parentheses are mine, but quotations and comments are taken from Russell.

July 2, 1835 (Jackson Hole). "This valley, like all other parts of the country, abounded with game."

July 28, 1836 (Jackson Hole). "Game is plentiful and the river and lake abound with fish."

August 19, 1836 (Outlet to Yellowstone Lake). "This valley was interspersed with scattered groves of tall pines, forming shady retreats for the numerous elk and deer during the heat of the day." Seven trappers killed a cow, probably in Hayden Valley, and a wolf was heard howling.

August 7, 1837. On the divide between Stinking Water and Yellowstone Russell's party fell in with a large band of bighorn.

August 12, 1837. The party crossed the divide (Jones Pass?) to the waters of the Yellowstone Lake "where we found the whole country swarming with elk."

July 10, 1839 (Old Faithful Area). "Vast numbers of black-tailed deer are found in the vicinity of these springs ..."

July 28, 1839 (Yellowstone Lake). Russell speaks of the Indians shooting at

a large band of elk. In late August (near Heart Lake) they fell in with a large band of elk and killed two cows.

In The Discovery of Yellowstone Park-1870, by N. P. Langford, the following observations were noted: September 6, 1870 (southeast corner of Yellowstone Lake): "We have today seen an abundance of the tracks of elk and bears, and occasionally the track of a mountain lion." On September 


\section{Fauna of the National Parks of the United States}

7, 1870, near the mouth of the Upper Yellowstone River, the party followed by mistake a fresh trail made by a band of elk.

F. V. Hayden (1872) gives some interesting light on abundance of game in Yellowstone and the difficulty of finding it even when abundant. $\mathrm{He}$ writes of Yellowstone: "The finest of mountain water, fish in the greatest abundance, with a good supply of game of all kinds . . . On the evening of August 9 we camped at the head of the main bay (Yellowstone Lake) west of Flat Mountain. Our hunters returned after diligent search for two and a half days with only a black-tail deer which, though poor, was the most important addition to our larder. It seems that during the months of August and September the elk and deer resort to the summits of the mountains to escape the swarms of flies in the lowlands about the lake. Tracks of game could be seen everywhere, but none of the animals themselves was to be found."

In the Sixth Annual Report of the United States Geological Survey of the Territories, by F. V. Hayden (1873), the following reference is made to game early in September 1872, south of Heart Lake in the Yellowstone Region: "This is mostly fine grazing ground and the numerous game trails give evidence that it is frequented by deer and elk; indeed, we found two herds of elk of about 20 each among the groves on the top of the ridge."

The following references to game occur in the Report Upon the Reconnaissance of Northwestern Wyoming, Including Yellowstone National Park, Made in Summer of 1873, by William A. Jones: August 2. On the divide between North Fork of Shoshone and the Yellowstone basin fresh tracks of mountain sheep were reported as exceedingly numerous. September 2, 1873 (10 miles up Upper Yellowstone River): "All through this basin game tracks have been very abundant, but our party from its size makes a good deal of noise, which will account for the fact that we did not see a great deal. A magnificent elk crossed the valley in advance of us, and in plain sight today.' On September 3, 1873, three elk were seen and shot at Two Ocean Pass.

The following notes are taken from the geological report made by Theo. B. Comstock, included in the Jones report: On August 6, near Pelican Meadows, the "doleful howl of a large wolf which was slowly approaching along the trail" was heard. The camp was on a "well-worn game trail. . . This locality seems to be a favorite resort of many animals. Our train approached it by following a prominent game trail, at least a dozen of which, extending for miles into the forest, meet at this point. Upon my first visit to this place, the day before the passage of the train, fresh tracks and other unmistakable signs of their presence were visible. Today I started 


\section{Ecology of the Coyote in the Tellowstone}

numbers of elk while passing through the fallen timber." On August 12, 1873, a badger was seen at Canyon and a porcupine was killed in Hayden Valley. The following is written about a trip from Pelican Creek to Mirror Plateau on August 13, 1873: "Plentiful tracks of game were noticed, but we saw very little until near the summit, when we met a large drove of elk and some deer." Item for August 19, between Junction Butte and Hellroaring: "On the way we met with several large droves of antelopes feeding upon fine pasturage here afforded with much security, owing to the irregular topography which enables them to seek immediate shelter upon the approach of danger. At the time of our visit the great antelope country along the left bank of the East Fork (Lamar River) was remarkably free from their presence, which may doubtless be explained by the recent passage of several parties of miners."

In "Report of a Reconnaissance From' Carrol, Montana Territory, on the Upper Missouri to the Yellowstone National Park and Return Made in the Summer of 1875," by William Ludlow (1876), the following statement indicates that many elk wintered in Yellowstone: "Hunters have for years devoted themselves to the slaughter of the game, until within the limits of the park it is hardly to be found. I was credibly informed by people on the spot, and personnally cognizant of the facts, that during the winter of 1874 and 1875, at which season the heavy snows render the elk an easy prey, no less than from 1,500 to 2,000 of these, the largest and finest game animals in the country, were thus destroyed within a radius of fifteen miles of the Mammoth Springs." This slaughter is mentioned in Norris's report of 1880 .

The following notes are taken from the zoological report prepared by George Bird Grinnell, published in the Ludlow report. Of mountain lions he states: "Although not a common species, a few of these animals are killed in the mountains every winter." One was seen near Alum Creek. Lynx were reported abundant in the mountains and sometimes killed in the park. Apparently, coyotes were present in some numbers in the mountains, for the following statement on their abundance is made in writing of the coyote: "This species is abundant between Carroll and Fort Ellis, being, I think, much more common on the prairie than in the mountains." The coyote was apparently very plentiful on the prairie where it was possible to see it much more easily than in the mountains. The above comparison suggests that the coyotes were present in some numbers in Yellowstone. Many wolverine tracks were reported in the park. The grizzly was reported as numerous in the park and black bears were scarce. Concerning elk, the following statement is made: "They were seen in considerable numbers

$193098^{\circ}-40-$ 


\section{Fauna of the National Parks of the United States}

along the Missouri River, among the Bridger Mountains, and in the Yellowstone Park." The bighorn and "the so-called mountain buffalo," were reported abundant in the park.

The following statements concerning early game conditions are taken from a typewritten copy of "A report made by Lt. G. C. Doane on an Exploration Trip from Fort Ellis Through Yellowstone Park and Jackson Hole to Fort Hall, Between October 11, 1876, to January 4, 1877."' Observations made in the summer of 1874 up Tower Creek are mentioned, which show that many elk had wintered in Yellowstone. He writes about a side trip made in 1874 as follows: "Late in the afternoon we reached the summit of the mountain toward Mammoth Springs, coming out in an open space where there were thousands of elk horns. There are many such places in the park where these animals have gone for centuries to drop their horns in early winter." On October 22, 1876, they were camped at Crystal Spring Creek near Canyon. He writes: "Hunted in vicinity of camp but found nothing." Later in Hayden Valley he reports ". . . saw that I had ridden close up to a herd of at least 2,000 elk. They had been lying in the snow and had all sprung up together, frightening my horse. In a minute the great herd was out of sight, crashing through the forest." A deer was killed 6 miles from Mud Volcano Springs near the mouth of the Yellowstone River. October 24, 1876, Yellowstone Lake: "In the morning I shot and wounded a large wolverine but did not stop him. . . ." October 26, 1876, Yellowstone Lake: "Killed a deer and two geese. . . . Mountain lions in chorus beyond the river, and a pack of wolves howling far down the lake shore." October 29, 1876, 1 mile from Heart Lake: "Driving a large herd of elk resting there we went into camp." November 18, 1876, on Snake River south of Heart Lake: "We have had but little depth of snow and this while favorable in one sense has been detrimental in another, as it has allowed the game to run high on the mountains where we had not time to go." South of Heart Lake a mountain lion had visited camp during the night.

In his annual report on Yellowstone Park for 1877, Supt. P. W. Norris gives a discussion of wildlife conditions in Yellowstone which corroborates the foregoing statements. He says: "Hence in no other portion of the west or of the world was there such an abundance of elk, moose, deer, mountain sheep, and other beautiful animals, fish and fowl, nor as ignorant, or as fearless of and easily slaughtered by man as in this secluded and unknown park but seven years ago . . . From the unquestioned fact that over 2,000 hides of the huge Rocky Mountain elk, nearly as many each of the bighorn. deer, and antelope, and scores if not hundreds of moose and bison were taken out of the park in spring of 1875 , probably 7,000 , or an annual aver- 


\section{Ecology of the Coyote in the Yellowstone}

age of 1,000 of them, and hundreds if not thousands of each of these other animals have been thus killed since its discovery in 1870. . . . As comparatively few of them were slain for food, but mostly for their pelts and tongues, often run down on snowshoes and tomahawked when their carcasses were least valuable, and merely strychnine-poisoned for wolf or wolverine bait, the amount of most wholesome, nutritious, and delicious food thus wantonly destroyed is simply incalculable." The fact that these animals were taken out of the park in the spring and that some were run down on snowshoes indicates that the animals must have been wintering in the park.

The following quotations are taken from Superintendent Norris' Yellowstone report made for the year 1880. Referring to Soda Butte Creek he writes: "A branch of the East Fork (Lamar) of the Yellowstone and a favorite winter haunt of elk and bison ... Elk, deer, and other game being driven by storms into the sheltered glens and valley, we were enabled to secure an abundant winter's supply of fresh meat, and also fine hides of the bear, wolf, and wolverine . . . I would add that there are now in the park abundance of bison, moose, elk, deer, antelope, and bighorn sheep besides fine summer pasturage there are winter haunts for these animals where with little care or expense other than protection from wanton slaughter, they would rapidly multiply." $\mathrm{He}$ mentions the presence of countless brush and stick fences of various ages created by the Indians for driveways in hunting game. Of elk he writes that in no place were they more abundant than in Yellowstone in 1870, and that a big slaughter of them occurred between 1870 and 1877. They were found at high elevations in summer and in sheltered valleys of the park during winter. Bighorns were recorded abundant throughout the park, remaining there the year round. The cougar was said to be exceedingly numerous in 1870 when Norris first explored the park, but already rare in 1880. Wolves and coyotes are reported to have once been exceedingly numerous in all portions of the park, but that the value of their hides and their easy slaughter with strychnine-poisoned carcasses of animals had nearly exterminated them by 1880 . Foxes, shunks, and badgers, are said to have been numerous in 1881 .

Edward Pierrepont in "Fifth Avenue to Alaska" wrote that bighorn were abundant in the Hoodoo Mountain area in 1883. Game Keeper Harry Yount in 1881 reported sheep wintering in large numbers at Norris Mountain.

The paleontologist E. D. Cope (1885) made the following statement concerning early conditions in Yellowstone: "Bison, elk, moose, deer, etc., are far less abundant than when the park was first created. The bison have been, I am informed, reduced to a herd of about 60 individuals, and the elk 


\section{Fauna of the National Parks of the United States}

have been decimated . . . Some persons state . . that the game leaves the park in winter. This I ascertained is not true, for there are numerous well-protected localities where the game winters safely."

M. S. Garretson, secretary of the American Bison Society, in a letter to Fred Packard, written February 2, 1939, gives a good historical description of early game conditions in Yellowstone Park and the plains country to the east. Mr. Garretson writes as follows: "My first acquaintance with the park was in the early eighties and I have been interested in it ever since. The knowledge gained then and since that time confirms my belief that prior to the advent of the white man the Yellowstone region was well stocked with game as were also the foothills and the open plains country. On the east and from the railroad on the south the game was being rapidly slaughtered by the advancing settlers and ranchers; at the same time on the western edge of the open country and in the foothills there were numerous hide hunters, market hunters, miners, and so-called sportsmen who worked eastward. After the game had been destroyed in the open country the hide hunters and market hunters continued their activities in the more difficult mountainous regions.

"The slaughter was prodigious even after the boundaries of the Yellowstone Park had been established. Thousands of elk and many bighorn sheep were slaughtered annually within the park for their hides and meat until a Federal law had been enacted for their protection, so it is quite apparent that instead of being driven into the park the original inhabitants were given the same treatment as was accorded to those in the open country and were slaughtered to near extinction, so there is good reason to believe that all the elk in the Yellowstone Park today have descended from the original inhabitants."

\section{COMPARISON OF THE PRIMITIVE AND PRESENT WILDLIFE STATUS}

IT IS DIFFICULT to reconstruct the primitive wildlife picture in Yellowstone even though a considerable number of early reports on wildlife have come down to us. There has not been opportunity to examine all the literature, but I feel that enough has been covered to make a general comparison of the primitive and present status of some species.

Elk.- It appears that formerly elk were accustomed to summer in Yellowstone Park in as large numbers as today or even larger; the early writings show that many elk wintered in Yellowstone. However, it is likely that more elk moved out of the park than at present, especially during 


\section{Ecology of the Coyote in the Yellowstone}

severe winters, thus resulting in a better adjustment between numbers of animals and the condition of the winter range. Yellowstone furnished a good winter range for a number of elk and the ranges outside the park were sometimes grazed bare by buffalo, a circumstance which may have affected elk distribution in this region during early times.

Mule deer.-It is probable that mule deer were formerly more abundant in the park in summer than today. I have seen no reliable information on early winter distribution in the park but since deer are now wintering on typical mule deer broken foothill range where winter conditions are favorable it seems probable that the early winter distribution in the park was much as at present.

Whitetail deer.-This species probably summered in the park in fair numbers in early days, coming into the park from the winter ranges along the Yellowstone River to the north, from Jackson Hole to the south, and perhaps from other surrounding valleys. As late as 1914 a hundred of these deer wintered along a short stretch of the Gardiner River near the north boundary. In the park the whitetail deer winter range was of small extent and was heavily browsed; the winter range of willow bottoms outside the park was usurped by ranchers. The vanishing of a suitable winter habitat for this brush-loving, secretive species was probably the basic cause for its disappearance. Vernon Bailey (1930, p. 69) writes as follows about the disappearance of the whitetail: "To a limited degree they were migratory in habits. Usually a part of those in the park drifted down the river valley in winter below the boundary where they had little protection and were an easy prey to pot hunters. A protected area below the park line could have saved them but this was not provided." In early times the whitetail was common in Jackson Hole, but there, too, they have largely disappeared. The few now remaining are reported from the Snake River Bottoms.

Buffalo.- In the early days buffalo were apparently found the year round in Yellowstone. Most of those living in the park when it was established were killed off by poachers. The propagation of a so-called "tame" herd on the Lamar River, together with the survival of a few of the original population in the Pelican Creek area, has resulted in a population of about 850 animals. The present distribution, because of transplants in Hayden Valley and the Old Faithful areas, is probably similar to the early distribution.

Antelope.-At one time antelope summered in Hayden Valley and the upper reaches of the Gardiner River as well as in the present summer range between Gardiner and Cache Creek. It appears that the summer antelope population is smaller now than formerly. Since the antelope winter range in the park is suitable, it is likely that a few of these animal always have 


\section{Fauna of the National Parks of the Lnited States}

wintered within the present boundaries. Formerly most of the antelope probably wintered in the Yellowstone Valley below Gardiner.

Bighorn. - In early days the bighorn summered in the park more widely and in greater numbers than at present and more of them spent the winter within its boundaries. Bighorns occurred in places where they are now absent.

Moose.-The abundance and distribution of moose have always varied. Their present status is probably similar to that of primitive times.

Cougar.-Formerly common in Yellowstone, cougars are now very rarely reported. They were hunted until they became scarce in the nineties. In 1914, 19 were killed by the use of dogs.

Wolf.-Although once present in good numbers, it is probable that none now remains. In 1912 wolves were reported, but none taken. In the 1914 annual report grey wolves were said to exist in the park, and at later dates some were destroyed. Poisoning was the principal method used to kill hem.

Other mammals.-The coyote has probably always been abundant in the park. Formerly the red fox was very common in the area: now it is relatively rare. Poisoning and trapping operations were undoubtedly the factors in its decimation. Wolverines and bobcats, once common, are now apparently gone; and lynx, which were formerly equally common, are extremely scarce at present.

Probably the present grizzly bear population does not differ widely from the primitive numbers. Black bears are apparently more plentiful now, although the data are rather fragmentary. George Bird Grinnell in 1875 found black bears scarce.

In all likelihood badgers today occupy much the same status as formerly. Fishers, once present, are now absent.

Birds.- Sage hens, at one time present in limited numbers, are now gone. They were probably killed off by hunters. Little brown cranes are not as abundant today as in primitive times, undoubtedly due to a general country-wide reduction in their numbers. Willett and greater yellow-legs, which George Bird Grinnell reported abundant in 1875, are now scarce or absent. This may also be due to a country-wide reduction in their numbers.

Conclusion.-The general pattern of wildlife today is similar to that existing when Yellowstone was first explored. There has been a reduction in some of the ungulates. but the big difference lies in the scarcity or absence of many of the predators. The relationships of the coyote to the rest of the fauna is today similar to what it was formerly. 


\section{Ecology of the Coyote in the Yellowstone}

\section{PREDATOR CONTROL}

IN EXAMINING the annual reports of the superintendents of Yellowstone it has been exceedingly interesting to observe the attitudes concerning predators which have been held in years past. Almost from the beginning a feeling against predators existed. Only occasionally is a voice raised in their defense, and then it speaks apologetically and with deference. This attitude toward predatory animals is easily understood, for one kill or an apparent kill makes a striking impression on the mind. The attention is held by an individual instance rather than by the effect of predation on the entire population. Because in the early days hunting was so wanton as to imperil the existence of game animals, much conservation thought was directed toward their preservation. Efforts were made to overcome every factor which might be considered in any way inimical to the well-being of the game. Hence predator control activities have persisted throughout the country and are constantly broadening in scope so that more and more species fall within this complex. The history of predator control in Yellowstone National Park is typical of that existing in many parts of the country. I have recorded here some of the early attitudes on predation and some of the data on control of predatory mammals in Yellowstone in order that we may better understand the human element that enters into the picture, and particularly in order that we may learn why certain forms have become rare or have disappeared from Yellowstone.

At the time Yellowstone National Park was established in 1872 there was considerable mining activity on the north and east at Cooke City. Miners passing between Gardiner and Cooke City hunted both carnivores and big game animals. There probably were also some market hunters in the area at this time.

Supt. P. W. Norris in his 1877 report on Yellowstone National Park described an orgy of big-game hunting which took place in the park during the late winter of 1874-75, and stated that many of the carcasses were strychnine-poisoned for wolf (timber wolf and coyote) and wolverine. There seems to have been much poisoning of flesh eaters in the park in this early period. In his 1880 annual report Norris stated that he and his party gathered fine hides of bear, wolf, and wolverine at the mouth of Soda Butte Creek. At this time moderate hunting for camp use was permitted in the park. In the report of 1880 the cougar was stated to be exceedingly numerous in 1870 and scarce in 1880 , so it is likely that many of them had been killed during this period. Wolves and coyotes were reported abundant in 1870 , but scarce in 1880 because of poisoning activities. Hundreds of 


\section{Fauna of the National Parks of the United States}

skunks were killed around Mammoth. Beavers were reported plentiful, but trappers had removed many of them.

Supt. D. W. Wear in his annual report for 1885 wrote of the unfortunate hunting activities which in the past had prevailed, and recommended that there should be no shooting or hunting of any kind allowed within the limits of the park. Moderate hunting by travelers for camp purposes was still being permitted at this time.

By 1887 it appears that practically all forms of wildlife were receiving protection. Supt. Moses Harris in his annual report of 1887 was not greatly concerned over the depredations of predators, as can be seen from the following quotation: "I have heard considerable anxiety expressed by those who profess interest in the park lest the rule which protects equally all animals in the park should work to the detriment of the game proper by causing an undue increase in carnivora. But while it is true that there are some noxious animals that are not worthy of protection, chief among which is the skunk, or polecat, yet I am convinced that at the present time more injury would result to the game from the use of firearms or traps in the park than from the ravages which may be feared from carnivorous animals."

That there was pressure for predator control from some source is also evident from Superintendent Harris's report of 1888. He had sent a scouting party into the park to observe game. They had traveled to Yancey, Specimen Ridge. Hayden Valley, Pelican Valley, and Norris, and had reported many elk, deer, and mountain sheep. Since tracks of only two mountain lions had been noted and few other carnivorous animals were seen, Harris wrote that the fear of those who believed that the game animals might be exterminated by the carnivora might be considered as without present foundation.

In the supplemental report to the annual report of 1889 the new Superintendent, Capt. F. A. Boutelle, recommended control of predators although with no reason except that they were becoming plentiful along with other animals. He wrote: "The carnivora of the park have, in common with other animals, increased until, I believe, something should be done for their extermination. This will be made the subject of a special letter. If the proposition is favorably considered the work should be done by persons under my control." Control of predators had at this time apparently not been resumed. In the 1890 annual report Boutelle again suggests control of carnivores although he reports the game animals increasing. He may have been inaccurate concerning abundance of the game but his reasoning is interesting: "The number of elk in the park is something wonderful . . . In the neighborhood of Soda Butte herds were seen last winter estimated at 


\section{Ecology of the Coyote in the Yellowstone}

from 2,000 to 3,000. The whole open country of the park seems stocked to its capacity for feeding. Other varieties of game animals are thought to be increasing rapidly." In the next paragraph he goes on to say that calf crops are too small: "As reported last year the herds of buffalo and elk do not seem to have enough calves. I am more than ever convinced that the bear and puma do a great deal of mischief and ought to be reduced in numbers. While they may be something of a curiosity to visitors to the park, I hardly think them an agreeable surprise. Very few who come here 'have lost any bear'.'

In his annual report for 1893 Supt. George S. Anderson reported that beaver were being taken by poachers in all parts of the park, so other fur bearers were no doubt being poached to some extent. In his 1895 report Superintendent Anderson stated that ". . . the park can well spare whatever of other game they (bears) may consume for their sustenance," thus showing a tendency toward a broad point of view on the subject of predation. In Superintendent Anderson's annual report for 1896 coyote control is recommended because the animals were numerous - not because they were injurious. The wording in the following passage from the report indicates that there may have been considerable pressure for control: "The game continues to increase and all varieties, excepting the bison, are found in great numbers. During the spring months the elk are found in their several winter ranges in herds of thousands. Deer wander through the Post, going within a few feet of the buildings and often as near to the men, who are about their work. The usual herds of mountain sheep and antelope have wintered on Mount Evarts and show great increase of numbers. The carnivora have also increased and have proved objects of interest to tourists. In the winter coyotes hereabouts became so numerous that I at last felt obliged to order the destruction of some of them, but I confined this duty to the authorized scout. I find the young of all the ruminants especially numerous and in good condition, so that I expect a large increase for the year."

Supt. S. B. M. Young in his report for 1897 requested that coyotes be controlled. His remarks indicate that there was a faction at that time friendly to the coyote. "The coyotes are numerous and bold. It is estimated that of a herd of 500 antelope that wintered in the valley of the Gardiner and on the slopes of Mount Evarts 75 (15 percent of the herd) were killed by coyotes during the past winter, and many antelope fawns, elk calves, and broods of grouse have been destroyed by them this season. The opinion has been advanced by a few of the friends of the park that if the coyote is exterminated the gopher in time would eradicate the grass 


\section{Fauna of the National Parks of the United States}

from the winter valley ranges. I do not concur in this opinion, and request authority to reduce the number so that they will not hunt in packs."

Supt. James B. Erwin in the annual report for 1898 writes as follows concerning control of coyotes: "Very numerous in certain sections. They do some damage to the young elk, but the young deer and antelope are their particular prey. Efforts are made in winter to keep their number down by poisoning carcasses of dead animals, and to a certain extent it has been successful." Concerning antelope and deer he wrote in the same report: "These (antelope) are yet numerous. The snow drives them from the mountains and high plateaus, their feeding and breeding ground in spring and summer, to the lower altitudes outside of the park, where many are killed (by poachers)." Deer were "numerous, on the increase." Poisoning of coyotes must have been quite successful, for in the diary of one of the scouts, published with the report, eight dead coyotes were found near the target range in 1 day (December 5).

In the annual report for 1899 the statement is made that the coyotes "undoubtedly kill many antelope, as well as young elk and deer. The only means of getting rid of them is by poison. This method will be tried during the winter." Deer and antelope were reported to be increasing. The statement was made that mountain lions ". . . are numerous and destroy much game. Several were killed last winter where the mountain sheep range." This is the first mention of official mountain lion control that has come to my attention although it was doubtless practiced earlier.

Supt. George W. Goode in the annual report for 1900 said that antelope were increasing even though many were wandering out of the park, where he felt they were almost sure to be shot. He appeared to be little concerned about coyote predation.

In the annual report of 1904 it is stated that the game animals were in good shape. The deer and bighorn were fed hay because of the shortage of range, and probably some antelope were fed hay but a definite statement on this was not found. In spite of the fact that the game animals appeared to be doing well and it was thought that the cougar preyed chiefly on the ubiquitous elk, the cougar were hunted with dogs, and 15 of them were killed, chiefly in the Mount Everts region. Concerning coyotes the following sentiment is expressed: "It is the general impression that coyotes are protected in the park, but this is far from true, for it is a well known fact that they are very destructive to the young game of all kinds, and we therefore use every means to get rid of them . . . They are also destroyed by the use of traps and poison, and during the past winter between 75 and 100 of these animals were killed." 


\section{Ecology of the Coyote in the Yellowstone}

The superintendent in his 1905 annual report was apparently somewhat tolerant of coyotes and cougar although control was practiced. He writes: "As the lions and coyotes are somewhat destructive to other game, such as elk, deer, and sheep, and also a pest to stockmen of the surrounding country, they are destroyed whenever the opportunity affords. The killing of these animals is, however, made a matter of business and not of sport, and only a few persons are permitted to do this killing, and they are scouts, and certain good shots among the soldiers."

The 1908 annual report shows that coyotes were still being killed, and that the cougar was again a rare animal. Following quotations are taken from this report: "It is a difficult matter to keep the coyotes down. Since my last annual report, which showed 99 coyotes killed in that year, 97 more have been killed. The growing scarcity of antelope, deer, and sheep in the States bordering on the park and the increase of these animals in the park causes the coyotes to gather here for their meat. One lynx was killed during the year. Also one red fox was shot by Scout Graham in the night time in mistake for a coyote . . Mountain lions are scarce. One was killed during the year. It was no longer necessary to keep the pack of hounds purchased in 1893 for the extermination of mountain lions, and under authority from the department the pack was sold, after advertisement, to the highest bidder."

Official record of certain predatory mammals destroyed in Yellowstone National Park ${ }^{1}$

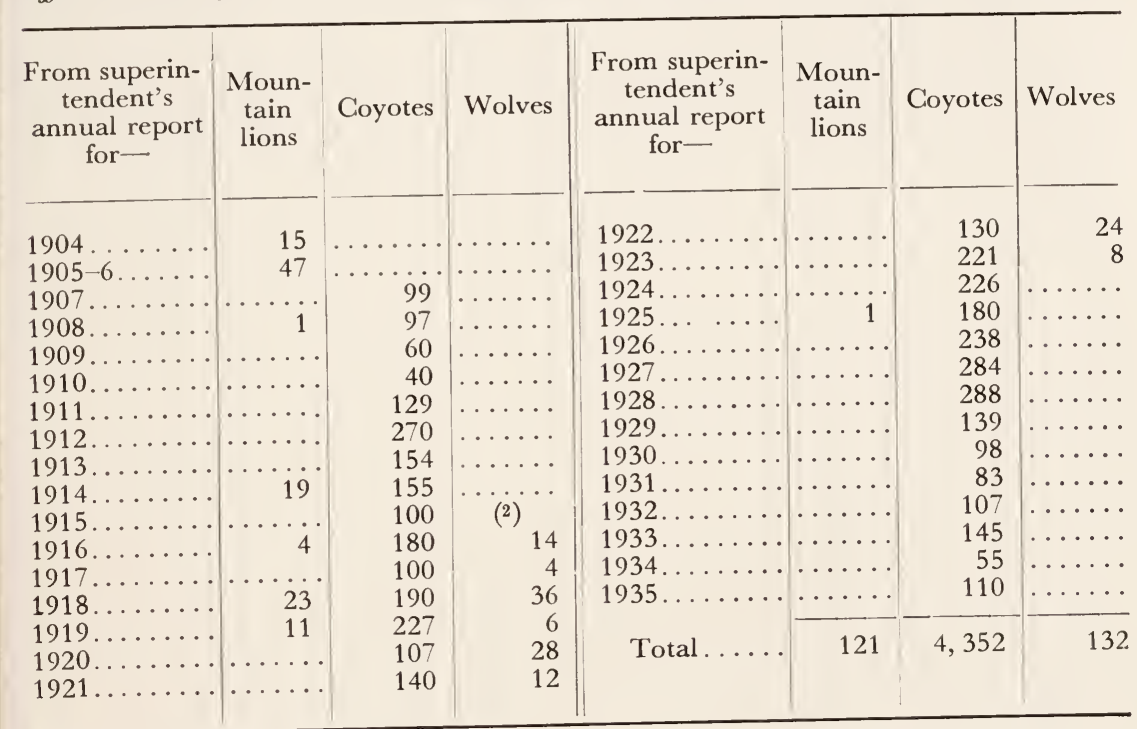

1 Taken from Skinner 1927, p. 239, and later official correspondence.

2 Several. 


\section{Fauna of the National Parks of the United States}

In 1909 the attitude of the superintendent in charge had changed. He wrote in his annual report: "Quite a number of coyotes were killed last year-about 60 in all-but still they seem to increase. It is doubtful, however, if they kill much game, as the deer seem to be able to protect themselves. On several occasions last winter, I saw deer chasing coyotes instead of being chased by them."

In 1912, by means of poison, traps, and shooting, 270 coyotes were killed and it is stated that many more still existed. The game animals had apparently been in good condition. A decrease in deer was noted in the fall of 1911 but this was probably correlated with the heavy mortality during the previous winter. More than 200 bighorn had been counted in the spring, many of which had been foraging outside the park.

The 1913 annual report states that 154 coyotes were poisoned, trapped, or shot. The 1914 report states that 155 coyotes were killed. Wolves were reported to have returned, and although none was killed, efforts were made to eliminate them. The cougar was again controlled by the use of dogs and 19 of them were destroyed. The big game animals were reported to be in good condition and thriving.

Predator control continued through the winter 1934-35. The last cougar was killed in 1925. Since that time definite authentic park records of cougar have not come to my attention. The last wolves were eliminated in the twenties although a few have been reported in recent years. Control was continued until the cougar and wolf and probably the wolverine, incidentally, were eliminated.

In line with the thought prevalent in the country today, there has evolved in the national parks the wildlife policy of basing any control of animals on thorough research. 


\section{Chapter II}

\section{POPULATION AND MORTALITY}

\section{NUMBERS OF COYOTES}

I

IS DIfFICULT to determine the size of a coyote population, because seeing the animals is a matter of chance and estimating their numbers from tracks is uncertain due to their wide travels. It would be interesting to see what results could be obtained by judiciously distributing a number of elk carcasses over the range during a period of food shortage and then making a simultaneous count of coyotes visiting each carcass.

Skinner (1927, p. 186) placed the fall population of covotes in the park at 400. He thought that the artificial control activities removed the yearly increase. It is my impression that 400 would represent the minimum number of coyotes in the park; how many more there might be is hard to estimate.

Since 1935, when control ceased, it is doubtful whether there has been any increase in the coyote population. Two park rangers interviewed felt that since coyote control was stopped the number of coyotes wintering in Pelican Meadows has remained about the same as when control was practiced. Three rangers and two park naturalists with whom the subject was discussed thought that there had been no increase of coyotes up to the spring of 1938. A man who ran a road grader almost daily between the Buffalo Ranch and Tower Falls in the summers of 1937 and 1938 said there seemed to be fewer coyotes in 1938 than in 1937. Others think that coyotes have increased since control was stopped.

In the winter of 1938-39 coyotes were generally reported scarcer at Mammoth. Some persons said that their howling had been seldom heard that winter. The apparent decrease of coyotes at Mammoth is balanced by an apparent increase in the Game Ranch area and in places adjacent to the park near Gardiner.

It was my impression that the coyote population in the spring of 1938 was no greater than in the spring of 1937 . This was based on the number of coyotes seen in the field and the relative abundance of droppings along the trail. During a period of less than 2 weeks in February and March 1939 coyotes appeared to be fully as numerous as in 1938 . The abundance 


\section{Fauna of the National Parks of the United States}

of carrion in the winter of 1938 would lead one to expect a good increase in the coyote population that spring. Since artificial control in the park was stopped, the coyotes have become tamer and therefore more often seen. This fact must be kept in mind in estimating abundance of coyotes before and after artificial control.

In the absence of artificial control some fluctuations of coyote populations are to be expected, depending on food supply, condition of snow, and disease. It will be highly interesting to observe the effect of these natural factors. As pointed out elsewhere, natural controls are continuously operative and it is possible that at times they may operate more drastically than would artificial control.

\section{MOVEMENTS OF COYOTES OUT OF PARK}

Since artificial control of coyotes has been discontinued in the park some complaints have been made that coyotes were moving into adjacent areas and that the park was thus serving as a breeding ground from which surrounding territory would be populated. Detailed data on this subject are hard to obtain, especially since all the surrounding territory is already populated with varying numbers of coyotes.

From general observations it appears that some of the territory adjacent to the park supports populations as large per unit area as Yellowstone. Coyotes are plentiful in Jackson Hole, where they are not officially controlled but are shot and trapped for sport and fur by the residents. The population there is so large that any influx from Yellowstone would make but little difference in total numbers. In early September 1937, I spent a week in the Shoshone National Forest, adjoining Yellowstone on the East. There I found coyote droppings rather commonly over all the trails, even those farther to the East, and plentiful on the North Fork. Along certain stretches of the trail the droppings were as abundant as found on any trails within the park. Apparently a large summer population of coyotes lived adjacent to the park in the Shoshone National Forest. West of the park the snow is deep in winter so that it is doubtful that many coyotes move out of the park in that direction.

In the Gardiner area on the north edge of the park I was anxious to learn what I could about the drift of coyotes since here there is a winter concentration of them. I interviewed a few persons who had been trapping along the north boundary and was able to make some observations of my own. On January 20, 1938, a trapper whom I met between Gardiner and Jardine said there were not as yet many coyotes around but thought 


\section{Ecology of the Coyote in the Yellowstone}

there would be more as soon as the Yellowstone River froze over. Thus far he had shot 14. Most of them were taken during the elk hunting season by waiting below Deckers Flat early in the morning and shooting the coyotes scared away from the offal by hunters. In the winter of 1936-37 he took 16, and the year before about 30 . He had made his biggest catch during the first winter that control in the park had ceased. When I saw this trapper in April he estimated that the total number of coyotes taken in the area adjacent to the north boundary of the park was about 45. On January 25, 1938, I met another trapper near Gardiner, who said he had caught only 5 coyotes, while the previous year he had caught 14 . A Jardine resident stated that there were not many coyotes outside the park. A trapper at Jardine stated on April 11, 1938, that about 40 coyotes had been trapped on the north side of the park the past winter. He had secured about 24 himself. Coyotes, he said, had been reported scarce between Gardiner and Yankee Jim Canyon. The previous year (1936-37) he trapped 15. He felt that the coyote population had remained nearly stationary during the period $1935-8$ and that the numbers were about the same during this period as they were before control in the park ceased.

In the winter of 1937-38 I frequently followed the Yellowstone River between Gardiner and Deckers Flat and found very few coyote tracks outside the park. Some coyotes were coming out to feed at Deckers Flat but these were not numerous. Although there was a large food supply on the flats outside the park consisting of elk offal left by hunters, there were also many elk carcasses available to the coyotes inside the park, so there was no special incentive for any movement across the boundaries.

Ranger Olson of the Forest Service, stationed at Gardiner, said that there is always a large coyote population in the Absaroka National Forest. This population has been estimated as follows: 1932 (920); 1933 (990); 1935 (900); 1936 (781). Ranger Olson believed that in the fall of 1935 there was probably a slight increase of coyotes in the Gardiner area; a decrease in the winter of 1936-37; and a further decrease in the winter of $1937-38$.

In the winter of 1938-39 there was doubtless an increase of coyotes in the Gardiner area outside the park. Their movements to this area may have been due to a shortage of carrion within the park, which in turn was caused by a heavy winter kill of elk in 1937-38 and a favorable winter in 1938-39. Furthermore, an unusual number of elk moved out of the park, followed by some of the coyotes. One trapper stated that his coyote catch went up each time a large band of elk crossed the boundary. On one occasion, when a band came across from Mammoth, he caught three 


\section{Fauna of the National Parks of the United States}

coyotes with poor coats. I saw the fur left on the legs of two of them after they had been skinned out and it was filthy. The offal and carrion resulting from the killing of nearly 3,000 elk during the 1938-39 hunting season was doubtless an added inducement for coyotes to leave the park. Trappers on the boundaries get the coyotes as fast as possible, which greatly minimizes any possibility of extensive movement to distant points in the surrounding States.

According to one trapper who had taken 69 coyotes near Gardiner, a total of about 150 coyotes had been trapped between Gardiner and Jardine and between Gardiner and Yankee Jim Canyon. The trappers were jubilant over the additional income which the good trapping yielded them. One expressed the hope that the park would not control coyotes again. However, the supply of coyotes in this trapping area comes not only from within the park but also from the adjoining Absaroka National Forest, where there is a large resident population.

The fact that many of the coyotes stay in the park until they die indicates the absence of any large movement beyond the boundaries. While a few individual coyotes probably travel a long way, there can be no doubt that the majority of the population remain in the park, or if they wander out they follow the elk herds. In view of the fact that carrion is generally concentrated in the park the incentive for leaving is usually not great.

\section{COYOTE MORTALITY AND NATURAL CONTROLS}

Natural control of populations is a subject on which we do not have much information, especially in the case of carnivores, and it is a question which is at present receiving much attention. Before the white man interfered we know that controls existed, and although there were cycles of abundance and scarcity among many forms, there appeared to be large numbers of predators and prey species coexistent over extended periods. According to mathematics, any species could flood the world in a short time if unchecked. What are the checks?

In Yellowstone, after 4 years of absence of artificial control, it is apparent that coyotes have not multiplied according to mathematical expectation. The evidence shows that the population spread has been very limited and has been only into areas adjacent to the park boundaries. As I mentioned before, several rangers and naturalists in Yellowstone have been interviewed and most of them believe that the coyote population has not greatly changed during the last 4 years. Some felt that there may have been even fewer coyotes in 1938 than in immediately previous years. They were 


\section{Ecology of the Coyote in the Yellorestone}

more plentiful in some areas, such as the Game Ranch area, in the winter of 1938-39, but were reported scarcer around Mammoth, suggesting a compensatory local shift in population.

My own impression, based on coyotes seen and frequency of droppings in the trails, is that the 1938 coyote population was quite similar to that of 1937 . There is no good way of measuring coyote abundance and we can make only rough estimates of the comparative sizes of populations from year to year. At any rate, coyote numbers seem to be remaining rather stable and not pyramiding.

To determine mortality statistics and causes for an elusive animal such as the coyote is a difficult task. Dead animals are not easily found in a wide expanse of country, so that even though quite a number of coyotes may be dying on the range each year one would not expect to find many, or even any, of them. Discovery of a carcass or what is left of it is largely a matter of chance. It was, therefore, not expected that records of many dead coyotes would come to my attention. The number that did come to light suggests that quite a number of coyotes are dying each year.

Fourteen dead coyotes were recorded in the winter of 1936-37, 10 in the winter of 1937-38, and 3 in 1938-39. Data for the last year are probably incomplete since I had spent only about 10 days in the field. These observations were made during the latter part of February and early March, and were discontinued at that time because of other duties. In addition to actual deaths, a number of sick animals were observed. The percentage of dead coyotes found was naturally small.

The causes of death could not be determined with absolute certainty, but in the following discussion the incidents are grouped in accordance with apparent symptoms. These suggested two general causes-starvation and disease. It should be kept in mind that this grouping is entirely tentative, that successful diagnosis has not been accomplished, and that much remains to be done.

Starvation.-In February 1937 Ranger Dave Condon found four coyotes at Tower Falls which were apparently starving. Condon states in his report for that month: "On the eighth a coyote was found at Yancey's ranch practically starved. On the ninth another was caught near the Yellowstone River Bridge, and on the tenth one was found near the station at Tower Falls. Two of the animals died before they were taken to Mammoth, the other was killed in Mammoth, and all were found to have been starving."

Dr. Howard Welch of the Montana Veterinary Research Laboratory of Bozeman, Mont., examined one of these coyotes and found no evidence

$193098^{\circ}-40-3$ 


\section{Fauna of the National Parks of the United States}

of disease or parasites. A fourth coyote was collected and examined by Raymond West but no cause other than starvation could be found to account for the poor condition of the animal. These coyotes were so weak that they were run down on foot within 60 yards. Condon reported that coyotes in general were in very poor condition in January. It was thought that the starving animals were young.

Conditions during the winter of 1936-37 were unfavorable to the coyote, for the snow was so loose that these animals had difficulty in traveling through it. On the other hand, the loose snow was only a slight hindrance to the mobility of the game animals in their search for food and they came through the winter in good condition. It is of significance that of 28 bighorn lambs wintering on Junction Butte only a single loss was reported by Condon. There were several deer at Tower Falls that apparently were not molested by the coyotes. Condon stated to me that the coyotes had great respect for the deer. When coyotes approached the deer, the hair on the backs of the latter raised as they assumed a threatening attitude and the coyotes retreated. The coyotes appeared to be actually starving in the midst of deer and bighorn.

The caretaker at Canyon stated that two coyotes had starved there during that winter.

Coyotes were reported to have been starving at Slough Creek and at the Buffalo Ranch. Coyote remains were found in eight scats at one of the haystacks at the Buffalo Ranch. The animal eaten may have been one of those that died of starvation. It seems probable that coyotes were starving in every part of the park during the winter. Trappers at the edge of the park in the Jardine-Gardiner area told me that the coyotes taken in the winter of 1936-37 were all extremely thin.

Remains of seven other coyotes which had died of unknown causes during the winter of 1936-37 were found. Some of these may have perished from starvation. Near the mouth of Elk Creek the remains of a large coyote which had probably died in April was examined on May 7. As the tips of all four canines were worn flat, the animal was undoubtedly an old one.

On May 11 at Yellowstone Lake I examined a coyote which had been found dead under one of the buildings. It was a female with well worn canines. There were no embryos. The animal was exceedingly emaciated, weighed only $133 / 4$ pounds, and had an empty stomach. Near the hip bone was a suppurated lesion about 1 inch in diameter, which may have been a contributory cause of death.

On May 13 at the base of Specimen Ridge opposite Trumpeter Lake I found fur remains and the tip of the tail of a coyote that had died during 


\section{Ecology of the Coyote in the Yellowstone}

the winter. This location is not far from Junction Butte where the bighorns were wintering.

On June 15 near Madison Junction remains of a coyote were seen in a coyote dropping, indicating that one had died in the vicinity.

On July 4 a coyote skeleton with some flesh and hide still attached was observed near Yancey's.

A coyote dropping was noted at Swan Lake and another above Oxbow Creek containing coyote hair.

Snow conditions during the winter of 1937-38, in contrast to those of the previous winter. were favorable to the coyotes in that heavy crusts made travel for them easy. Nevertheless, the remains of 10 coyote carcasses were found. Four of them were located where food was plentiful, but the remains of the other six were found in areas where food was scarce, so that these animals might have become weak and died from food shortage. On the north side of the park, deer, and especially elk carrion, was abundant because of the heavy winter kill among these species. As food in this area was readily available to the coyotes, starvation was not a mortality factor on the elk winter range.

Mrs. Margaret Gary (Yellowstone Nature Notes, March-April 1938, p. 18) reported finding two dead coyotes near the South Entrance and Ranger Tom Gary told me that later a third was found there. One of these was found January 27, 1938, one on February 26, 1938, and the third later. All were very thin and their stomachs were empty. Numerous porcupine quills were found in the throat and over the body of one of them. Very little big game winters in this area, hence there would be little available carrion. As the deep snows make mousing difficult and the snowshoe hare is not abundant, starvation in this case was likely.

Rangers Lee Coleman and Robert Beal found a dead coyote at the Thorofare Station on the Upper Yellowstone which may also have starved.

On April 13 Rangers Lee Coleman and Walter Gammill brought me a coyote carcass which they had found on upper Slough Creek. It was very thin, weighing only $13 \frac{1}{2}$ pounds, and the stomach was empty. Since not many elk wintered on upper Slough Creek the latter part of the winter, there would be but little carrion available. This coyote also may have starved.

In June a dropping in Pelican Meadows contained a mass of coyote hair. This is not a clear case and the condition of the dead animal that had served as food is of course unknown, but starvation during the winter in this particular locality is a possibility. 


\section{Fauna of the National Parks of the United States}

On February 26, 1939, Ranger Condon captured a thin, weak coyote at Yellowstone Lake. This animal might have been starving. In addition to these more recent records, Ranger John Jay said that about 1932 he and Ranger Al Elliott had captured a weak coyote at Yellowstone Lake.

Starvation as a population control.-All the foregoing cases are characterized by extreme emaciation and the absence of any bodily evidence of specific disease or parasites (facilities for bacteriological examinations were lacking). Furthermore, they appeared to be associated with food scarcity. In view of these facts, starvation may have been the cause of death.

Food scarcity may operate in two ways to control coyotes: through death of individuals and through reduced reproduction. It has been thought that in the classic case of the lynx-rabbit cycles in the far north not only do many lynx starve during times of rabbit "lows," but many of the survivors fail to breed. It is generally recognized that reproduction is affected in varying degrees by food shortage or by an unbalanced diet. Hamlett (1938) states that female coyotes come into heat for only a short period and that the occurrence of two heat periods in the same year is doubtful. This would make it possible for a short period of starvation to sharply affect reproduction if this period should coincide with the breeding time. Thus winters unfavorable to coyotes may be followed by a decrease in number and size of litters.

Starvation among other carnivores is not unknown. The lynx has already been mentioned. In the Arctic regions the white fox is known to starve during certain winters and in some sections native trappers scrutinize the apparent crop of mice and lemmings in the fall, attempting to anticipate the probable harvest of fox furs for the coming season.

O. J. Murie has informed me that in the winter of 1914-15, during an expedition in Hudson Bay, there was a decided die-off of white foxes. Frequently little piles of white fur and the tail were found in the spring which, according to the Eskimos, were the remains of starved foxes that had been consumed by survivors. Two dead foxes, both greatly emaciated and one of them partly eaten by a raven, were found. Incidentally, field mice and lemmings were so scarce that it was with difficulty that a few were obtained for specimens.

Such conditions are, after all, comparable with those observed among the coyotes in Yellowstone.

Disease.-It is, of course, possible that some of the coyotes which seemed to have been starving may have died primarily from disease. At any rate, in addition to the cases of apparent starvation there were others clearly involving disease. 


\section{Ecology of the Coyote in the Yellowstone}

On August 26, 1937, a sick coyote was captured near Tower Falls and kept in the barn for more than a week. It appeared dazed, lay down most of the time, but occasionally stood up and turned in a circle. When I saw it on September 2 it was much better, although it had not recovered sufficiently to be wild and was still readily handled. It ate a large quantity of meat, there seeming to be no limit to its capacity. At this time the animal limped on a front foot and acted as though it had received a severe blow on the head. It may have been hit by an automobile.

Ranger Condon informed me that one of the tame coyotes at Tower Falls during the winter of 1936-37 was frequently seen jerking its head downward, and that in the winter of 1938-39 he had seen a coyote at the Mammoth dump and one near Gardiner with the same jerky movements of the head. Such nervous movements are characteristic in a number of diseases.

On September 28, 1937, at Gibbon Meadows I watched a coyote, apparently a pup, which acted abnormally. During the 10-minute period that I watched it hunting mice and grasshoppers it frequently shook its head and sometimes also its body. The shaking was done repeatedly as though it were trying to rid itself of some discomfort. It happened to trot into the woods where I was standing and ran off rapidly upon seeing me. Assistant Park Naturalist Oberhansley, in Yellowstone Nature Notes (November-December 1937), reports finding a sick coyote in Gibbon Meadows on October 11. This was about 2 weeks after I had noted at the same place the distressed coyote previously described; possibly it was the same animal in a later stage of some disease. Oberhansley stated that the coyote would alternately lift one hind leg and then the other, jerking them rythmically forward and upward.

It was suggested that the action resembled the early throes of distemper. When the coyote ran, Oberhansley was easily able to keep up with it, and when pursuit was stopped the coyote walked about 10 feet and lay down on its side, panting. When approached, it fled again in an awkward manner, its hind legs failing to "track." Finally, when cornered on the bank of the Gibbon River, it laboriously swam the stream and stood on the opposite bank, the hind legs alternately jerking spasmodically. Oberhansley suggests that since dogs are kept at campgrounds the coyotes that visit those areas could easily pick up a distemper infection from them.

On September 9, 1938, a bus driver picked up a coyote pup near Sheepeater Cliff and brought it to Canyon where Temporary Ranger Jean Young took charge of it. Young stated that the animal was extremely thin and too weak to stand. It made convulsive jerks, especially in the rear quarters. 


\section{Fauna of the National Parks of the Lnited States}

For 2 days it would not eat, but on the third day it was induced to take some milk, with apparent relish; later it was fed gravy with a little cod liver oil. Its appetite became ravenous and it improved rapidly in every respect, finally becoming too strong to handle readily. It was released on September 17 , still retaining a slight twitch in the hind legs.

If the coyote had not been nursed it would doubtless have died, having been too weak to seek food. The incident suggests that starvation is an important secondary cause of death in animals which must spend some effort in gaining a livelihood. A slight ailment may cause disinclination to hunt and a consequent period of fasting, which, if continued for several days, may have a cumulative weakening effect. Eventually the animal, primarily due to lack of food, becomes physically unable to hunt and dies. Such an animal on the other hand, if fed, might readily recover. Since the coyote nursed at Canyon apparently had not fully recovered as indicated by the persistence of the twitch in the hind leg, it is possible that, when it returned to the woods, it again became weak.

Three of the dead coyotes reported during the winter of 1937-38 may have died from disease. At the Daisy Geyser in the Old Faithful area, where food is usually available, remains of a coyote were found in June by a temporary naturalist.

On February 9, in a patch of willows along the Gardiner River near Mammoth, I came upon six coyotes which had been feeding on another one and had cleaned it up except for one hind quarter. Most of the ribs had been consumed and the skin had largely been removed from the skull. This coyote had died during the day, for rigor mortis had not yet set in. On February 13 the skull of a coyote which had died rather recently was found along the Gardiner River. The teeth were much worn. These two coyotes could not have been starving, for food in this area was readily available at the Mammoth and Gardiner dumps in the form of carrion.

In the spring of 1938 Ranger Rudolf Grimm found the remains of a coyote near the Game Ranch, where food was plentiful. This one, too, may have died of disease.

Below Deckers Flat, a few hundred yards from the park boundary, a trapper during the winter of 1937-38 found two thin coyotes which showed no evidence of any wounds. These animals may have died from disease for a number of elk carcasses strewn over the area excludes the possibility that there was a food shortage.

During the winter of 1938-39 Assistant Naturalist Oberhansley followed the tracks of a coyote in the Mammoth area to the place where the animal had curled up in the snow and died. When he found the carcass it had 


\section{Ecology of the Coyote in the Tellowstone}

been partially consumed by another coyote. In the same area he found the fur remains of another coyote, and saw a weak, thin one that had been lying at the edge of one of the hot pools. Since food was not scarce these animals, too, were probably diseased.

In the fall of 1938 coyotes were noted dying of disease in Jackson Hole. On October 5, O. J. Murie examined a dead coyote on the Elk Refuge. Workmen had found it very thin and weak on October 2, and had killed it with a stone. The cause of its weakness could not be determined, but at this time of year food was abundant. Early in September a guide found a small emaciated coyote up the Gros Ventre River. He fed it, and, feeling sorry for it, put a coat around it that night. Next morning it was dead. On October 7, O. J. Murie examined a dead coyote which had evidently been sick. A local resident had killed it the previous day with a rock. The lips and mouth of the weakened animal were encrusted with numerous wartlike growths. This same man had seen three other coyotes during October that appeared sick. He had not killed them, although his dog had been able to catch up with them easily and "stop them." It may be of some significance that in parts of Jackson Hole coyotes were scarce in the winter of 1938-39. South of the park, in the Pacific Creek drainage, no coyote tracks were noted by Rangers Condon and Gilbert on a trip made in February. Possibly the diseased animals noted in the fall were only a portion of a larger number of affected animals in Jackson Hole. One of the animals trapped there in the winter by one of the residents also had the wartlike growths about the mouth, but the general condition of the animal was not learned.

An abnormal coyote was also noted in the winter of 1935-36 in the Jackson Hole region. Two local wardens were going up the Gros Ventre River when they came upon it feeding at an elk carcass. Their dog had run up quite near the animal but was called back. One of them shot at the coyote but missed, and it did not even flinch. After a moment the coyote happened to turn and saw the two men. Then it became apparent that one side of the animal was almost bare of fur and that it had a nervous movement, repeatedly "bowing," as one of the wardens expressed it. As it departed, one front leg seemed useless and a hind leg partially so as if paralyzed. Since the fur was not good the men did not shoot it. They concluded that the coyote was diseased and stone deaf.

Diseased coyotes and wolves are occasionally mentioned in the literature pertaining to them. Bailey (1926, p. 151) quotes the following observations taken from the journals of Alexander Henry: "A large wolf came into my tent three times, and always escaped a shot. Next day, while hunting, 


\section{Fauna of the National Parks of the United States}

I found him dead about a mile from the fort; he was very lean and covered with scab."

Warburton Pike in Barren Ground of Northern Canada, p. 52-53, writes about wolves: "I saw only wolves of two colors, white and black, during my stay in the North, although I heard much talk of grey wolves. There was some sort of disease, resembling mange, among them in the winter of 1889-90, which had the effect of taking off all their hair, and, judging from the number of dead that were lying about, must have considerably thinned their numbers."

Probably disease has always affected coyote populations periodically, just as in the case of game species, hares, lynx, foxes, and other animal forms. Disease, and possibly also starvation at times, operate most effectively when the population is large.

Mortality due to porcupine quills.-When opportunity offers, coyotes prey regularly on porcupines. It is reported by rangers that during the period when control of coyotes was practiced in Yellowstone a large number of them carried porcupine quills. Generally the presence of the quills had no deleterious effect. Often they were lodged no deeper than immediately under the skin. It is conceivable, however, that occasionally a coyote may become so impregnated with spines as to eventually cause death, and there is some evidence to that effect. Under "Brevities" (Yellowstone Nature Notes, October 1929) the following incident is given which shows that a coyote had been rather seriously "stuck up" by a porcupine. A Mr. Fisher of the park transportation company had found a coyote "with more quills in his mouth than the ordinary porcupine has in his body." He approached within 5 feet of the animal, and could have easily killed it with a club, for the coyote was more interested in extracting the tiny barbs than he was in the presence of the man.

O. J. Murie (1935, p. 12) gives the following incident: "That the coyote does not always fare so well is indicated by an experience related by Forest Ranger Jack Tevebaugh, who was stationed in the Upper Yellowstone in the winter of 1930-31. In the latter part of March he shot a coyote that was extremely emaciated. It was found to be full of porcupine quills, in the skin, in the tissues under the skin, on the head, and even inside the mouth. On the head were two festering sores."

When food is scarce the coyotes probably are less circumspect in their attacks on porcupines, and suffer more severely from the quills.

Attacks by elk and other ungulates.-Coyotes as a rule are too quick to be caught under the stabbing hoofs of an elk or a deer, but fatalities of this kind have occurred. E. J. Sawyer (Yellowstone Nature Notes, February 


\section{Ecology of the Coyote in the Tellowstone}

1927) reports an observation made by Ranger Bruce between Mammoth and Blacktail in which an elk had apparently killed a coyote. The dead coyote, badly mutilated and with a broken back, was found in the midst of a much trampled area in the snow, over which blood and hair were scattered. Tracks showed that it was an elk that had killed the animal.

Ranger Clifford Anderson at the Game Ranch on April 27, 1931, found a dead deer and dead coyote lying side by side. There was no mention in his report concerning the conditions of the animals or the cause of death.

On February 9, 1938, I watched a doe deer nearly strike a coyote. She kept reaching out for it with striking front feet and the coyote dodged the sharp hoofs only by great effort.

The trapper.-In modern times it is necessary to add the trapper to the list of controls of coyote populations, even in the case of a national park. While it is true that the Yellowstone coyote population is essentially a self-contained unit, subject to the ecological influences felt by such animal units, nevertheless it is not entirely contained within the political boundaries. Observations mentioned previously show that some coyotes go outside the park, probably for limited distances, but nevertheless far enough to become available to trappers in the vicinity who gladly take advantage of this occasional surplus of fur supply. As stated previously, many trappers who were interviewed expressed the hope that the National Park Service would not control coyotes so that they might have the opportunity to capitalize on the occasional surplus. Trapping is a small but persistent drain on the Yellowstone coyote population. 


\section{Chapter III}

\section{HABITS}

\section{BEHAVIOR AT CARRION}

O November 13, 1937, on upper Oxbow Creek, a number of soaring slope. From a prominence I could see some coyotes as well as several magpies, at the carcass. Lying contentedly on a knoll 150 yards away was a coyote which had apparently had its fill, for it was relaxed on its side and showed no interest in its surroundings. One coyote was at the elk and chased away another which approached to feed. Soon a fourth came to the place on the run. As it approached it put its head down and arched its back. The coyote at the carcass fled; it seemed to recognize the newcomer as its superior. Two coyotes trotted over a rise out of sight.

Although it was a dull, grey day I moved up nearer in order to try for some pictures. As I was approaching the carrion a coyote appeared on the skyline about one-third of a mile behind me. It trotted briskly toward the carcass, passing about 60 yards to one side of where I was crouched. I circled the dead elk and came up to within 75 yards of it, shielded from the coyotes by a few fir trees. There were now five coyotes, standing shoulder to shoulder, tugging at the meat. The ravens had seen me from afar and had left, but eight or nine magpies were there. Magpies on the carcass were sometimes thrown off balance by the tugging of the coyotes. One by one, four of the coyotes left the carrion and trotted away. Each of the four, upon leaving the carcass, vigorously rubbed its throat and muzzle, and sometimes its chest, on the grass to clean the fur. In this way, the blood and dirt were thoroughly wiped off. The fifth coyote remained several minutes after the others had left. When finishing, it also wiped its muzzle and then howled half-heartedly.

When all the coyotes had gone, I hunched up against a niche in some bare rocks 50 yards from the carcass. There was no cover near at hand. In a few minutes a coyote came over the slope behind, and, upon sighting me from a distance of 15 yards, galloped out in the flat. It made a large half circle around the carcass, moved back to a knoll 100 yards away, and lay down. The magpies in the meantime were busy gorging themselves 


\section{Ecology of the Coyote in the Tellowstone}

and carrying away quantities of scraps to cache in the scattered neighboring groves.

In a few minutes another coyote appeared and approached the carcass, weaving back and forth several times before coming to it. This coyote seemed hungry, feeding rapidly and jerking at the carcass vigorously. The magpies were perched all about it, only 2 or 3 feet away. Once the coyote made a dash at the magpies, apparently to chase them away. Sometimes it received a start when a magpie alighted only a couple of feet from its head. It was finally attracted by the noise of my camera shutter and trotted up to within 10 yards of me before it recognized what I was and galloped away.

I walked nearer the carcass to photograph the magpies and crouched about 20 yards from it to wait for the magpies to reassemble. I had barely taken a position when another coyote came into the area and trotted directly to the carrion without noticing me. However, it apparently got my scent for it dashed away. I had been at the carcass for 3 hours and estimated that during this time it had been visited by 10 different coyotes.

On November 13, 1938, at 8 a. m., I found a dead bull elk in the sage about 75 yards from the road near Blacktail Creek. I later learned that the elk had been killed by a truck on the evening of November 11. At the carcass were 5 coyotes, 12 ravens, and 10 magpies. At 4 p. m. there were 6 coyotes, who, with one exception, left shortly after. This one tugged at the flesh in the usual manner, sometimes bracing all four legs, but more often only the front legs. It occurred to me that the hyena, which feeds chiefly on carrion, may have developed its fore legs and shoulders at the expense of the hind quarters by a feeding habit at carrion in which it used mainly the front legs.

On the morning of November 14, there were 3 coyotes at the dead elk, 3 others within 50 yards of it, and 6 more scattered out over the sagebrush either going or coming. No doubt the presence of a carcass becomes widely known, causing more and more coyotes to assemble. One of the three at the carcass seemed especially pugnacious, at intervals driving off the other two animals, and dashing after the magpies, of which there were a dozen hopping and flitting over the body. After being driven away several times one of the coyotes moved off, but the other was finally tolerated and wedged itself between the hip bones in its efforts to get at some uncleaned portion of the skeleton, which was fast becoming bare of flesh. Later another coyote approached in the characteristic challenging attitude with back arched and jaws wide open. It galloped and trotted in this attitude for about one-quarter of a mile. Without hesitation it 


\section{Fauna of the National Parks of the United States}

attacked the first coyote it encountered, which was the pugnacious one. There was a momentary sparring with jaws as both humped up, but the newcomer bumped his shoulder against the other and forced it to retreat, then dashed after some magpies, and, after strutting once around the elk remains, began to feed. Soon a light-colored coyote boldly approached and attacked. There was resistance, but after some snarling and scuffling the one at the carcass moved off a few feet. His back remained arched and he returned to feed undisturbed. The third coyote was still feeding between the hip bones. Some ribs and leg bones had been carried off 50 or 60 yards to a spot where several minor quarrels and some bluffing took place, similar to that occurring at the carcass. Ravens sat in the snow at varying distances from the carrion, which they had left on my approach. Once a raven tried to fly off with a rib in its bill. Three or four times a coyote approached a raven that was feeding and, when the raven flew, examined the spot where it had been.

Four coyotes ran off together across the sage and over the ice of a small pond. The large one in the lead was attacked several times by the one behind it so that it had to stop and face about to protect itself. This nipping seemed to be done in play.

Some of the coyotes rested in the sagebrush between 50 and 400 yards from the carrion. Once eight coyotes trotted off, three of them bunched in the lead, the others straggling behind at various intervals. Some of them spent a little time hunting mice. During the morning there were several brief fights, one in which a coyote rolled over on its back and was bitten somewhat around the throat.

In the afternoon I approached within 35 yards of three coyotes at the carcass in order to take pictures. They were so occupied that I was able to move gradually into full view and take a number of pictures. They paid little attention to the noisy camera shutter. One of the coyotes saw me, but after running off a short distance and seeing the others remaining, it returned and lay down 60 yards away. The coyotes were active throughthe day, coming and going to the carcass continually.

Where the coyotes are depending mainly on carrion for food and there is not sufficient to go around, it is very probable that there is an elimination of the weak and a survival of the fittest. The weak can only eat after the strong have feasted, and if the strong devour what there is, the weak would of course go hungry and become weaker.

\section{CACHING}

THE coyote often caches surplus food. This may vary in amount from a whole deer quarter to a piece of deer meat an inch or two in diameter 


\section{Ecology of the Coyote in the Tellowstone}

such as was found cached one-third of a mile from a carcass on lower Blacktail Deer Creek on November 20, 1937. On February 15, 1937, coyotes were observed hiding large pieces of a deer, and once a coyote was observed moving away from an elk carcass with a leg bone. Often it has been observed that deer have been "cleaned up" in a single night. Although much of a deer may be eaten on the spot, it is likely that a large part has usually been carried away. In northern Minnesota I have frequently found snowshoe hares stored under the snow by coyotes.

\section{COYOTE-RAVEN RELATIONSHIPS}

IN WINTER, when a considerable part of the diet both of the raven and the coyote consists of carrion, their similar interests draw these two species together. They are interested in each other's actions; the raven watches the coyote and the coyote watches the raven. If one has found a source of food he is sure to be joined sooner or later by the other. The coyote-raven relationship is an example of a loose symbiosis.

At a carcass, the raven, because of its wider view when in the air or on top of a tree, frequently warns the coyote of approaching danger or other intrusions. The coyote is usually occupied tugging at the carcass while the ravens are scattered about, some at the carcass, others soaring or sitting in nearby trees, so it is difficult for anything to escape their notice. The coyote takes their warning and becomes alert, but it may only look around briefly, and, seeing no danger, continue to feed. Some incidents may serve to show how closely ravens and coyotes observe one another when food is involved.

On May 12, 1937, in Pelican Meadows I watched a coyote hunting on a snowdrift. After a short period of intent watching it pounced. This was followed by a little digging in the snow and some more quick pounces. A raven flying overhead turned its course and lit on the snow 10 yards from the coyote. Here it remained patiently waiting for about 5 minutes while the coyote dug some more. The latter then took a few alert steps, only to return again to the same spot. When the coyote wandered off, the raven walked to where the coyote had been digging and gave the spot a thorough investigation.

On the morning of January 15, 1938, I saw a coyote trotting along the base of Mount Everts on the margin of a wide flat. Near the opposite side of the flat a raven was standing on a snowdrift. When the coyote had trotted to a point opposite the raven and about 200 yards away it turned its course directly toward the raven on the snowdrift. The bird by that time had been joined by a second one which had alighted to feed on a tiny food morsel it had been carrying. When the coyote was somewhat less than 10 


\section{Fauna of the National Parks of the Lnited States}

yards from the feeding raven it made a quick dash for the bird. The raven easily escaped and lit again a few yards to one side. The coyote sniffed the spot where the raven had been feeding and then made another dash for it. These tactics were continued for some time. It appeared that the coyote chased the raven in order to pick up some fragment of food that might be left behind because of the sudden departure. The coyote made six or seven dashes at the bird before it flew off about 250 yards. After peering at the departed bird, and seeming to hesitate whether or not to follow, the coyote trotted after it. When the coyote had covered half the distance the raven circled back over the coyote, which looked up at it as it wheeled 15 or 20 feet overhead.

The raven lit on the snow again to feed on its food morsel and the coyote trotted along as if to pass it, but suddenly turned to make another quick charge. These rushes, as before, were repeated five or six times. Once the coyote leaped high in the air toward the raven and rolled over twice when it hit the snow. The raven finally flew away along the river and coyote disappeared in a draw. It appeared that both animals were enjoying the fun, for the raven could easily have flown away to escape if it were annoyed, and it would seem that the coyote, which was probably well fed by the abundant carrion, would not have been so persistent unless he were enjoying the play.

In the winter of 1937-38 on the Federal Elk Refuge in Jackson Hole one of the men reported a coyote playing with a mouse. A raven was attending the coyote and would try to get the little creature when the coyote left it out of reach. Before the raven could get the mouse the coyote would retrieve it. This game continued for some time.

At the Mammoth dump on March 29, 1938, a raven and a magpie were perched a few yards from a coyote which was chewing vigorously on some food. The moment the coyote left, both birds and a second magpie flew at once to the spot and quickly picked up the crumbs. The crumbs left by the coyote were no doubt easier to eat than was most of the garbage. The alertness and watchfulness of the birds indicated that feeding on the small morsels left by them was a common practice.

On February 15, 1938, I witnessed an incident which showed that the ravens could be quite vexatious. A short distance above the mouth of Bear Creek several ravens were circling low and lighting on the ground, across the Yellowstone River from me. Through my binoculars I made out two coyotes tugging at a carcass lying on a bench sloping away from the river. About 15 ravens, the number varying because of continuous arrivals and departures, were near the carcass. Some were in the air, 


\section{Ecology of the Coyote in the Yellowstone}

some perched in the nearby trees, and some on the ground by the carrion. Magpies, as usual, were also assembled and hopping about barely out of reach of the coyotes. Frequently during the hour that I watched, the coyotes made rushes at the magpies and ravens, not, it seemed, in any attempt to catch the birds, for they never followed through with their attack, but rather to drive them away. For about 20 minutes the coyotes continued feeding. I was on the bank of the river opposite the carrion and from this point it was just out of my view, and so, at times, were the coyotes feeding on it. One of the coyotes seemed small, with a scraggly lighty-colored coat. He had a lame left front foot which was used lightly and sometimes not at all. This lame member of the group presently started up the slope carrying the front leg and shoulder bone of a fawn deer with most of the hide attached. When he had gone up the slope about 10 yards a large dark coyote followed with a rush, causing him to drop his burden and retreat for a few yards. The dark animal, with back sharply arched, head held low, and lips drawn back from his teeth, returned to the carcass. The lame one cautiously retrieved the deer quarter and moved up into a small grove of Douglas firs. Six or seven ravens followed him as he went, circling a few feet above. In a few minutes the lame coyote emerged from the grove where he had cached the carrion. He looked back up the hill toward the grove where some ravens were lighting in the trees, apparently having some misgivings about the security of his cache. He then carried a second large piece of the meat into the grove and was followed by the dark coyote which was carrying a quarter with most of the meat removed but with much of the hide still clinging loosely. The dark coyote disappeared in the grove, but later crossed an opening higher up the slope, still carrying what remained of the deer quarter. He dropped his load on the snow and stood looking alternately at his burden and at the circling ravens which had been following closely. He was not so naive about making his cache as was the lame one, who did not seem to realize that potentially all the ravens in the region knew the location of his store. The dark one seemed much dismayed. He probed his nose into the snow, picked up the bones, looked up at the ravens, and walked into another grove. The ravens followed, perching on the trees along his route. The coyote moved a long way up the slope to still another grove where he again stood watching the ravens, seeming completely perplexed. When he moved into the woods I left the scene for I had been watching for more than an hour with the temperature about $30^{\circ}$ below zero. As I left I caught a glimpse of a third coyote at the carcass. The caching of the remains shows why carcasses at times so quickly disappear. 


\section{Fauna of the National Parks of the United States}

\section{COYOTE-MAGPIE RELATIONSHIPS}

AlONG with the raven, the magpie is closely associated with the coyote during the winter months. In the same manner, the magpies were observed to warn coyotes of danger.

At times it seems that there must exist a compact between magpies and coyotes, for often these birds at a carcass hop about only a few feet from the coyotes. Magpies are very alert and cannot be readily captured by coyotes, who no doubt learn that their efforts along that line are rather futile and after a time stop trving. I have seen a coyote chase magpies away from a carcass, apparently with no effort to harm them. However, occasionally a magpie is eaten, for feathers were once found at a dead buffalo and magpie remains have been found in at least one stomach of a coyote that appeared to have been feeding on carrion.

\section{FAMILY HUNTING GROUND}

IN 1937 Gibbon Meadows was apparently the hunting ground of a coyote family. These animals were frequently seen hunting in the meadow and had spent much time resting and playing among the small scattered groves of trees along the edge of the meadow. There were many freshly worn trails in the grass, numerous beds, and several places where coyotes had been digging around the roots of trees. Many droppings occurred in the open as well as among the trees. A total of 162 droppings were found in the place on September 3 and 4. The pups had climbed logs and upturned roots of fallen trees in their play. One of the pups was seen on September 4 at the rendezvous. Grasshoppers occurred here in varying amounts up to 100 percent in 95 of the droppings, which suggests that the pups eat more grasshoppers than the adults.

\section{SOCIABILITY}

Coyotes move alone or in small groups. If two or three are together, any one of them is likely to go off on a lone excursion. Often several coyotes are assembled at a carcass, or in the same meadow hunting mice, but any one of these may have wandered to the area alone and is likely to depart alone. On meeting, two coyotes may trot toward each other, may even touch noses, and, after hunting about near each other, move apart. In winter small groups of coyotes often travel together; as many as six have been seen in a group. Usually these bands seemed to consist of family parties. On March 25, 1938, I watched six coyotes which were resting 


\section{Ecology of the Coyote in the Yellowstone}

together and apparently on friendly terms. Two seemed to be adults, but of course identification was not certain. As will be related under coyote-deer relationships, four of these coyotes had passed close to some deer and after stopping near them for a short time had wandered off out of sight. They reappeared on the slope near the top of the ridge at 11:30 A. M. The group, apparently an adult and three pups, after howling together, lay down on the snow, the pups flat on their sides with necks arched far back, the old one occasionally looking casually to either side. After a while all four looked up the slope on which a large coyote and a pup appeared. The latter came down the slope and stopped on a bench about 60 yards above the others. The big one, an adult, took a position on a flat rock and lay on his stomach, his legs stretched forward and paws hanging over the edge of the rock. He seemed to be watching over the four below him sleeping in the bright sunshine. The pup stretched out on its side in the snow a few yards away. The old one with the three pups walked over to one of them and nosed it. The pup lay quiet except that it pushed its nose toward the old one, who then walked up the slope, passing within 3 or 4 feet of the big coyote on the rock. It approached the single pup, which rolled over on its back with both front legs doubled up. The old one smelled of the pup's stomach, then it too stretched out flat on the snow. Presently the animal on the rock faced the old one and the pup, and lay on its side. All six coyotes were now lying flat; none were watching. After 45 minutes had elapsed all but one of the pups trotted away; this one slept 15 minutes longer. It was aroused by some deer a short distance from it, which jumped away when they saw me approaching the coyote in my stalk for a picture. The coyote looked toward me, where I crouched in plain sight on the open snow slope, but did not rise until it heard the click of the camera. Then it jumped up and trotted toward me, veering to one side so that it passed me at a distance of 35 yards. It circled behind me at this distance until it got my scent, then, cautious and not very much alarmed, trotted off in the direction the others had taken.

An observation, related by Almer Nelson, in charge of the Federal Elk Refuge on the outskirts of Jackson, Wyo., illustrates well, it seems to me, the spirit of comradeship in the coyote. At daybreak, in the middle of the winter, Nelson looked out of his window and saw six coyotes scattered over the fields hunting for mice. While he watched, the coyotes in their hunting gradually moved toward a center until they were all assembled. Here they sat in an irregular circle and howled in chorus. The clamor soon came to an end and the coyotes dispersed over the fields, each going on its way, to return again in the evening.

$193098^{\circ}-40-4$ 


\section{Fauna of the National Parks of the United States}

\section{PLAAY}

Coyotes are playful like dogs. Along the Yellowstone River below Crevice Creek, tracks showed that coyotes were wont to play on an open bench. Several times I passed the area after a fresh snow, and each time it appeared that coyotes had been dashing about on it. In the trails I occasionally saw sticks which the coyotes had been chewing. Once I saw a coyote coming toward me along the trail carrying a sprig of sagebrush. At intervals he tossed the branch into the air and caught it.

\section{SWIMMING}

Coyotes were occasionally seen crossing small streams, such as the Lamar and Gardiner Rivers. In midwinter Ranger Gammill saw an undisturbed coyote swim the Yellowstone River above the mouth of Blacktail Deer Creek. Upon emerging from the water a coyote will generally shake itself and frisk around to remove the water from its coat and get warm. Apparently on occasion coyotes do not hesitate to enter water and even cross deep, swift-flowing rivers.

\section{LIMITATIONS ON TRAVEL}

In the North, sled dogs frequently get sore feet, so that it is often necessary to equip them with moccasins. A crust through which dogs break, or coarsely crystallized snow, may wear raw spots on the sides of the toes, so as to cause them great discomfort. If conditions are bad a dog team may be considerably crippled. Some dogs are more subject to injury from unfavorable snow conditions than others, but all are susceptible.

It is probable that the coyote is less subject to sore feet than most domestic dogs, but many signs were observed that coyotes are also subject to this affliction. Two or three coyotes were seen which had a slight, almost imperceptible, limp characteristic of snow-injured feet. On a number of occasions little specks of blood were found in coyote tracks. These were especially prevalent during one period when a light crust, which had formed on the snow, was too weak to bear the weight of the coyote, and the animal broke through the surface from $1 \frac{1}{2}$ to 4 inches. At this time the snow had taken a coarse crystalline form which aggravated the effects of the weak crust. Such snow conditions probably handicap the coyote sufficiently to reduce its movements.

\section{TOLERANCE OF HUMANS}

Coyotes often become quite tame when protected, just as they become exceedingly wary and wild when hunted. Occasionally an exceedingly tame 


\section{Ecology of the Coyote in the Yellowestone}

and friendly coyote is found in a litter of pups. During the winter of 1936-37 a coyote became so tame at Mammoth that it was frequently fed and as a result of close association with it at least one person was bitten. This animal was finally shot because of its undue familiarity-another example of the unfortunate consequences sometimes resulting from feeding and taming wild animals that are large enough to injure a person.

During the winter of 1936-37, when the coyotes were hard pressed for food, two or three frequently came to the ranger's residence at Tower Falls to feed on garbage and to get food morsels tossed to them. One of these coyotes became so tame that it would come to the cabin when the ranger whistled. The following summer a tame coyote, apparently the one which had been fed during the winter, was seen several times at Tower Falls. By throwing pieces of cheese to it we were once able to bring it within 6 or 7 yards of us.

Dr. Frank Oastler told me that he found a coyote in Hayden Valley which was so tame that it would almost feed from his hand. I met a coyote in Hayden Valley the following summer that came trotting up within 15 yards of me. After I had returned to the car for a camera he became more wary.

Sawyer, in Yellowstone Nature Notes (November 1924, p. 3), reports a coyote pup coming up within 40 or 50 yards of him while he was tying a horse at the Canyon barn. The pup apparently returned several times, for Sawyer writes: "A few days later this companionable coyote called at the Canyon Ranger Station, whereupon his intercourse with man came to an end."

Since the cessation of control in the park, coyotes in general have become less wary and are therefore probably more in evidence along the roads. This is a factor that must be taken into consideration in comparing the present size of the coyote population with what it was when control was practiced. 


\section{Chapter IV}

\section{FOOD}

\section{STUDY TECHNIQUE}

I

$\mathrm{N}$ STUDYing the role the coyote plays in the Yellowstone faunal complex I tried first to learn the food habits of the animal. But his food habits do not tell the whole story, for after we learn what the coyote eats it must be determined what effect it has on the prey species.

The food habits were studied largely by means of dropping examinations. Droppings were gathered at every opportunity from all localities visited, special efforts being made in critical areas to get numbers large enough to be significant. Localities selected for special study included water bird nesting and wintering habitats, and elk, bighorn, and antelope fawning grounds. Rather large collections of droppings were secured from the following areas: Old Faithful, Gibbon Meadows and Elk Park, Virginia Meadows, Swan Lake, Tower Falls, Specimen Ridge, the Horseshoe, Buffalo Ranch, Hayden Valley, Pelican Creek, and a stretch along Willow Park. Smaller collections were secured from other localities. The quantitative data on food habits secured from the examination of droppings were supplemented by observations of the animals in the field.

In winter, information concerning the food habits of coyotes on the winter game ranges could best be secured from general field observations, for it so happened that the coyotes were living largely on elk and deer, mainly in the form of carrion. At this season it was more difficult to secure a large collection of droppings, for frequent snows and trampling prevented an accumulation of them on the surface of the trails. Enough winter droppings were examined, however, to substantiate the field observations.

In studying food habits by means of droppings it is essential that they be properly identified. Since coyote droppings vary considerably in size and conformation according to the quantity and kind of food eaten, there would be considerable question as to proper identification in localities where other predators are also present in large numbers. In Yellowstone where foxes, lynx, and wolves are very scarce, or absent, and badgers relatively scarce, there was little chance of many misidentifications. 


\section{Ecology of the Coyote in the Yellowstone}

Some droppings were examined in the field or at camp. Where difficulty was encountered in making identification in the field, the contents were wrapped in paper or cheesecloth and examined with care later. Most of the material was examined at Jackson, Wyo., where comparative specimens for identification were available. At Jackson each dropping was washed in a sieve or in its cheesecloth wrapper beforc being examined.

In analysis, the number of droppings in which an item occurred and the number of individuals present were tabulated. Volume was not measured. To determine the number of individuals of a species present in a dropping the part of the anatomy was used which gave the highest count. For instance if two left mandibles, three right mandibles, and two right femurs of a pocket gopher were sorted out, the right mandibles would show that at least three pocket gophers were represented in the droppings. The bones of the skull, particularly the rostrum and the mandibles, the long bones, and sometimes the tails were most useful as an index of the number of individuals represented in a dropping. Although sometimes the quantity of fur present indicated that more than one animal was represented, if such could not definitely be proven only one individual was tabulated. By following this conservative policy some individuals of the smaller mammals were no doubt missed, but the number missed is probably not significant and is at least partially compensated by possible duplications elsewhere.

The different species of field mice and of some of the other genera represented by closely related species were lumped since, for the purposes of this study, it was felt that it was not worth the considerable effort involved in making specific identifications.

Special effort was made in the field to get information on the amount of carrion taken since it is highly important to know the cause of death of animals utilized. This information is very difficult to obtain, but in some cases sufficient data were secured to greatly change the conclusions which one would ordinarily reach. Considerable data were secured on the condition and age of animals that were killed by coyotes and of those available as carrion.

It is more difficult to determine the effect of the coyote on prey species than to learn the food habits of the animal. In cases where the food-habits study shows that a species is eaten to only a limited extent it usually can be concluded that the effect of the coyote on the species is negligible. If the status of the prey species is favorable it can be concluded that any coyote depredation taking place is not harmful to the species. Conversely, when the status of a prey species is unsatisfactory it becomes important to 


\section{Fauna of the National Parks of the United States}

determine the part the coyote is playing. In some circumstances all factors bearing on the species must be studied.

Considerable space in the report has been given to the food habits and inter-relationships of the ungulates. Emphasis has been given to this phase of the study because much big game predation in the light of data at hand is closely bound up with condition of the animals, which in turn is dependent upon range conditions. Effort was made to investigate the survival of the young at various times of the year and to correlate winter survival with forage supply. Sample counts of the ungulates were made to learn the percentage of young present in the population at various times of the year. In effect, the problem demanded considerable information on each species and much attention was given to this phase of the subject.

\section{ITEMS IN THE COYOTE DIET}

DURING the course of the study 5,086 coyote droppings, containing 8,969 food items, were collected. With the exception of less than 200 of them, containing 185 items, all droppings were gathered from the first of April to about the middle of November. Of the 185 items present in those collected in winter, 119 were deer and elk remains and more than 50 of the remainder were in droppings which had undoubtedly been deposited in the summer and fall. The following table, therefore, except for about 119 items of deer and elk, pictures the food habits during the April-to-Noven ber period.

In addition to the foregoing, more than 200 winter droppings not included in the table on page 43, were examined in the northern part of the park. These contained deer and elk remains. In this area where deer and elk winter, these animals, mainly as carrion, make up practically the entire food supply. In the interior of the park snowshoe hares and mice enter more extensively into the winter diet.

About 3,500 droppings were obtained during 1937, a few in 1936, and the remainder in 1938. The material was not tabulated separately for each year since there was no significant difference in the incidence of the items.

Below are listed the number of individuals of each item found in the droppings. Except in the case of the field mouse and pocket gopher, and in a few instances the ground squirrel and deer mouse, the number of individuals present coincides with the number of droppings in which they occurred. Such items as insects, vegetation, and carrion were arbitrarily listed as number of times occurring, rather than number of individuals, since such material is not otherwise readily comparable with the other food items. For instance, the number of individual grasshoppers, crickets, june beetles, 


\section{Fauna of the National Parks of the United States}

Classification of 8,969 individual food items found in 5,086 coyote droppings gathered in Yellowstone National Park-Continued

Food items

\section{Small Mammals-Continued}

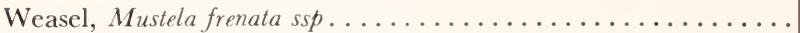

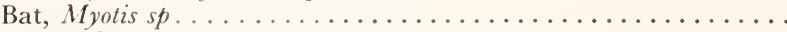

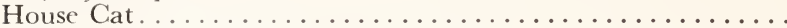

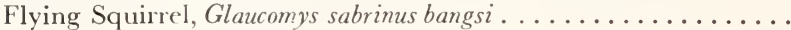

Marten (immature), Martes caurina origenes.

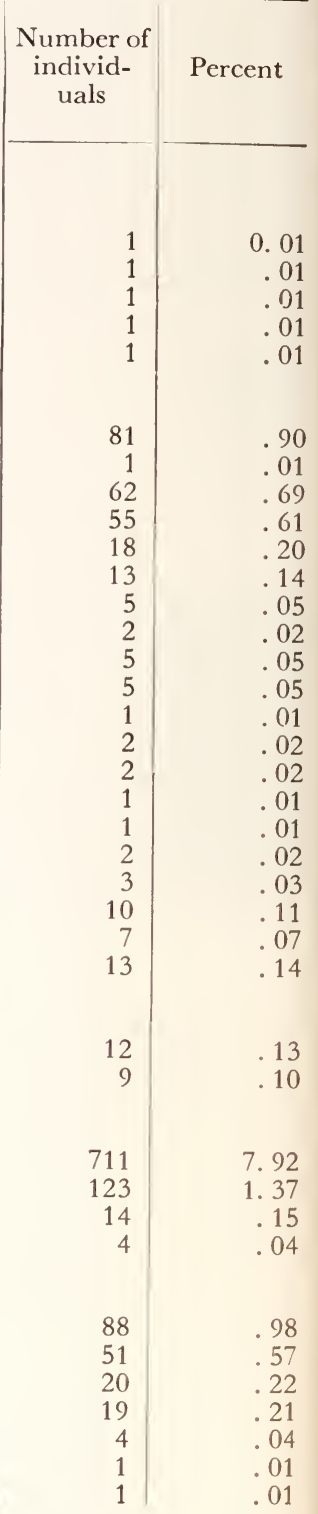

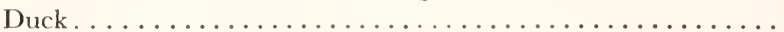

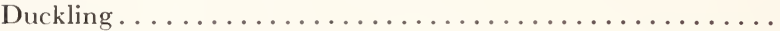

Bird

Small Bird

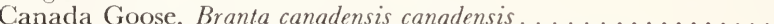

Richardson's Grouse, Dendragafus obscurus richardsoni.........

Ruffed Grouse, Bonasa umbellus umbelloides. . . . . . . . . . . . . .

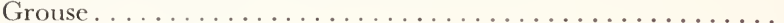

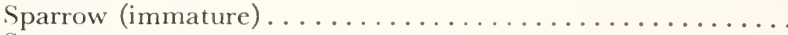

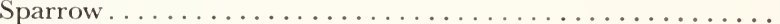

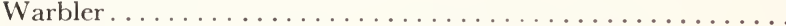

Steller's (black-headed) Jay, Cyanocitta stelleri annectens. . . . . . .

Spotted sandpiper, Actitis macularia . . . . . . . . . . . .

Short-eared Owl, Asio flammeus flammeus. . . . . . . . . . . . . .

Eared Grebe, Colymbus nigricollis californicus..............

Domestic chicken (refuse) .

Large bird egg

Small bird egg.

Domestic chicken eggshell (refuse)

Fish Cold-Blooded Vertebrates

\section{INVERTEBRATES}

Grasshopper...........

INVERTEBRATES

Cricket (Anabrus simplex) $\ldots \ldots \ldots \ldots$

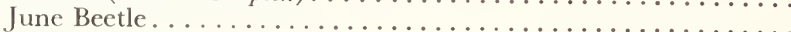

Snail.

\section{Vegetable Matter}

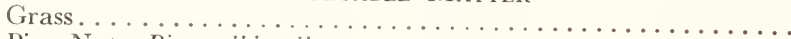

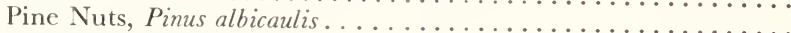

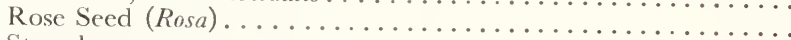

Strawberry . . . . . . . . . . . . . . . . . . . . . .

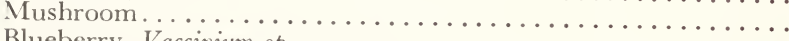

Blueberry, Vaccinium $s p$.

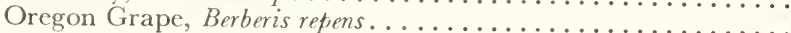




\section{Ecology of the Coyote in the Yellowstone}

Classification of 8,969 individual food items found in 5,086 coyote droppings gathered in Yellowstone National Park-Continued

\begin{tabular}{|c|c|c|}
\hline Food items & $\begin{array}{c}\text { Number of } \\
\text { individ- } \\
\text { uals }\end{array}$ & Percent \\
\hline Miscellaneous Food and Nonfood Items & & \\
\hline Horse manure . . . . . . . . . . . . . . . . . . & 48 & 0.54 \\
\hline 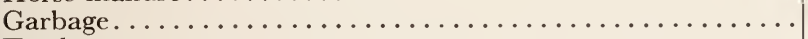 & 12 & 13 \\
\hline 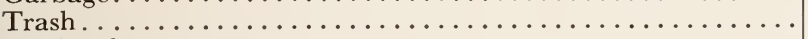 & 13 & .14 \\
\hline 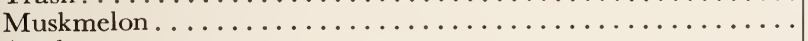 & 9 & 10 \\
\hline 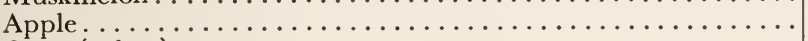 & 7 & .07 \\
\hline 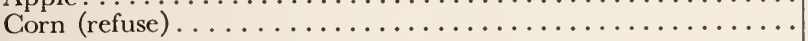 & 7 & .07 \\
\hline Paper. . . & 11 & .12 \\
\hline Canvas-leather glove . . . . . . . . . . . . . . . . & 6 & .06 \\
\hline 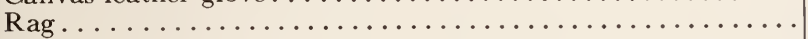 & 5 & .05 \\
\hline 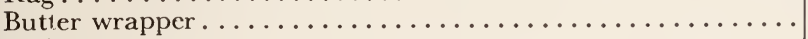 & 5 & .05 \\
\hline 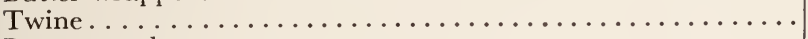 & 4 & .04 \\
\hline Banana peel . . . . . . . . . . . . . . . . . . . . & 4 & .04 \\
\hline 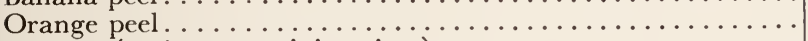 & 3 & .03 \\
\hline 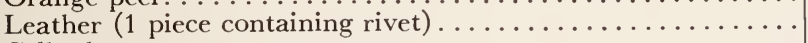 & 3 & .03 \\
\hline 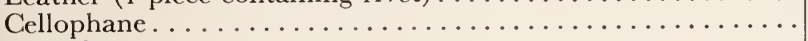 & 2 & .02 \\
\hline Steak bone . . . . . . . . . . . . . . . . . . . . & 2 & .02 \\
\hline 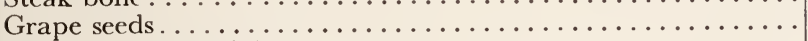 & 2 & .02 \\
\hline 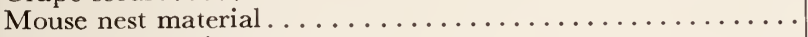 & 1 & .01 \\
\hline 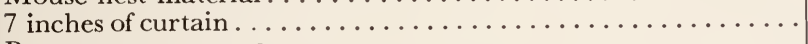 & 1 & 01 \\
\hline 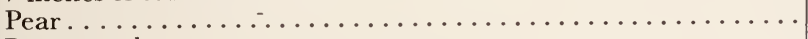 & 1 & .01 \\
\hline 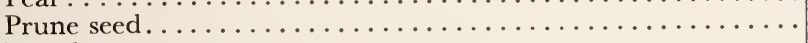 & 1 & 01 \\
\hline 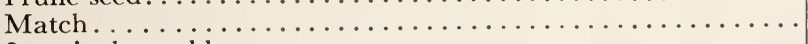 & 1 & .01 \\
\hline 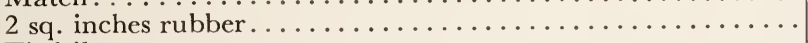 & 1 & .01 \\
\hline 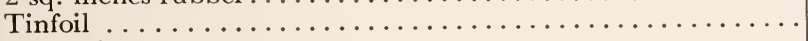 & 1 & .01 \\
\hline 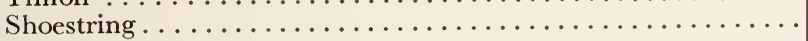 & 1 & .01 \\
\hline 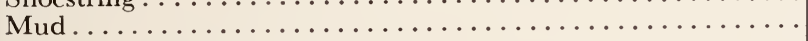 & 1 & .01 \\
\hline 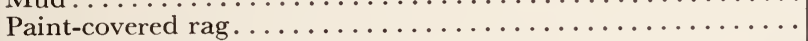 & 1 & .01 \\
\hline 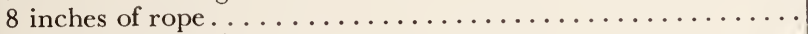 & 1 & .01 \\
\hline 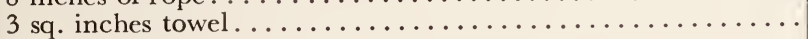 & 1 & .01 \\
\hline 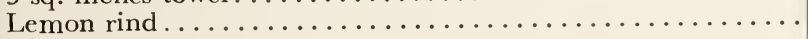 & 1 & .01 \\
\hline 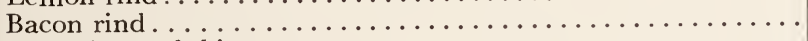 & 1 & .01 \\
\hline 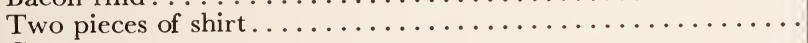 & 1 & .01 \\
\hline 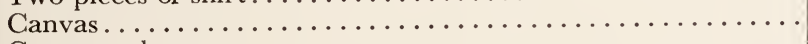 & 1 & .01 \\
\hline 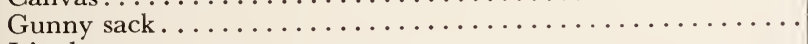 & 1 & .01 \\
\hline 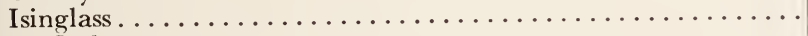 & 1 & 01 \\
\hline 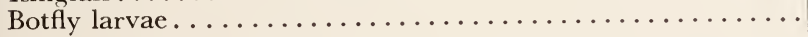 & 1 & .07 \\
\hline
\end{tabular}




\section{Chapter V}

\section{ELK IN RELATION TO GOYOTES}

\section{ELK AS COYOTE FOOD}

$\mathrm{E}$

LK CARRION is an important source of winter food for the coyote and also furnishes considerable summer food. There are about 11,000 elk (Cervus canadensis nelsoni) in the northern Yellowstone herd, more than 7,000 of which were counted within the boundaries of the park in the winter of 1937-38, the remainder having crossed into the Absaroka National Forest north of Gardiner. Those in the park wintered largely on the north side between Mammoth and the Buffalo Ranch. Some of the bulls winter on the higher slopes along the upper Lamar River and on Mount Washburn. Formerly quite a number wintered in Hayden Valley but in late years scarcely any have been found there. A few are found along the Madison River and in thermal spring areas, such as Old Faithful, where the warmth in the ground melts much of the snow.

Each year, mainly in winter, a certain number of animals perish, usually the calves and the older adults. The "winter kill" may be due to a variety of causes, such as old age, necrotic stomatitis and other diseases, heavy tick infestation, and malnutrition. The losses are generally light, but in winters during which snow conditions are unfavorable they may be large. In the winter of 1936-37, when conditions for elk were favorable, losses were light and the coyotes went hungry. During the winter of 1937-38, losses were relatively large and so an abundant food supply was available to predators. The heavy crusted snow conditions prevailing during the entire winter, along with the scarcity of browse, such as Douglas fir, willow, and poplar, made conditions especially unfavorable to the elk. As winter progressed, the elk became thinner and the mortality mounted, coming to a peak in April. Elk carrion was so abundant that there were always carcasses on the range, untouched or only slightly eaten by coyotes, even as early as January. The rangers found more than 500 carcasses and in the course of my field work I came upon 282, half of which were found on the poorer range along the Yellowstone River. The number of animals found each month was as follows: 


\begin{tabular}{|c|c|c|c|c|}
\hline Month & Bulls & Cows & Calves & $\begin{array}{l}\text { Uniden- } \\
\text { tified }\end{array}$ \\
\hline 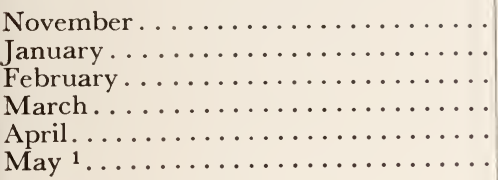 & $\begin{array}{r}1 \\
4 \\
5 \\
10 \\
30 \\
5\end{array}$ & $\begin{array}{r}2 \\
7 \\
2 \\
18 \\
56 \\
9\end{array}$ & $\begin{array}{r}6 \\
7 \\
\\
11 \\
36 \\
10\end{array}$ & $\begin{array}{rr}15 \\
\\
\\
\\
\\
\\
3 \\
34 \\
9\end{array}$ \\
\hline Total . . . . . . . . . . & 55 & 94 & 70 & 63 \\
\hline
\end{tabular}

1 Many of these had died in April.

A few elk die during the summer, thus supplementing the staple summer diet of field mice and pocket gophers. A total of 1,153 of the droppings collected, mainly during the spring, summer, and fall months, contained elk remains. In 1937, coyotes were observed feeding on a bull elk on June 3; a cow so weak she fell down several times was seen on July 14 ; and a thin weak cow still in the winter coat was seen on July 12. Elk hair is frequently found in coyote droppings during the summer. Calves are eaten during the calving season, and this food item will be discussed in considerable detail in the succeeding sections.

There was no evidence that coyotes killed elk calves in winter, and I feel certain that such predation must be light and that only weak or disabled animals, away from the main bands, would be attacked. In the following incident coyotes are reported to have been hunting a calf elk. Unfortunately the condition of the calf is not given. Reports of coyotes molesting elk are very rare. Observations of elk indicate that the relationship between coyotes and elk is usually similar to that described by former Park Naturalist E. J. Sawyer in his comments on the incident reported by Ranger Cottrell. The incident and comment from Cottrell's note (Yellowstone Nature Notes, February 1928, p. 4) follow:

I saw a calf elk running down the ridge at high speed and stopped to observe the cause of the excitement. The elk was followed by a lone coyote at a distance of about 50 feet which was gaining rapidly as the animal approached. The calf stopped to fight the coyote away, and at this time four more coyotes appeared and circled the calf; all four were going in the same direction; they gradually closed in as they circled the distressed animal and the fifth coyote held it at bay. They had closed in and were rushing and snapping at the calf when I decided there was no chance for it to escape and opened fire on its attackers. I killed two of the coyotes and the others escaped. One of the coyotes killed had been struck and bruised by the elk in its frantic efforts at self-defense. I have seen six other calf elk during four recent patrols that had to all appearances been attacked and killed in this manner. 


\section{Fauna of the National Parks of the United States}

\section{Comments by the park naturalist:}

The above described incident recalls to mind that I have seen two or three coyotes at once close to a yearling elk so weak from winter conditions that it could hardly stand, and of course quite incapable of escape or self-defense. Yet the coyotes were merely circling about it. Again, along the Lamar River, at a point opposite Specimen Ridge I once came upon a young elk too weak to rise. Fresh coyote tracks in the snow round about indicated that these animals had reconnoitered the elk, but there had been no attack. Returning by the same route a day or two later, I found the elk still there and still alive and all conditions as before.

It is not implied that coyotes pressed with hunger will not kill elk, deer, or antelope on occasion and under certain conditions. What is implied is this: that, under normal conditions of available food in the form of winter-killed animals-carcasses put out as bait, mice, ground squirrels, and so on - the coyote will not ordinarily kill any of the larger animals. He then even prefers to wait until elk, which he might easily kill, die of starvation. Finally, such weakened elk as the coyotes may destroy in late winter would be those most likely to succumb to weather and food conditions (winter-killed) in a short time; so that the coyotes' work in such instances is often an act of mercy, and, economically considered, an act wholly beneficial to the herd.

The following observation quoted from a typewritten report on trumpeter swan studies submitted in 1939 by Assistant Park Naturalist Frank R Oberhansley shows a calf elk-coyote relationship similar to that found by Sawyer.

March 17: On the right bank of the Yellowstone River about 2 miles below the mouth of Blacktail Deer Creek, a mature coyote (Canis latrans) was surprised at close range, gnawing upon an old weather-beaten elk skull. About 100 yards farther down stream an elk calf was encountered lying near the trail in such a weak and emaciated condition that it was unable to regain its feet. Fresh tracks of the coyote in the snow plainly showed that he also had seen the calf earlier that morning and that he actually detoured away from it in arriving at the old skull farther up the trail.

During the course of this snowshoe trip down the Yellowstone from March 16 to 18 inclusive, three other elk calves were observed in a weakened condition similar to the one described above.

Elk calf mortality.- During the calving season the coyote feeds extensively on elk calves as is evident by the occurrence of remains in 290 droppings. In 1937 carcass remains of 14 elk calves were found. The calf mortality noted seemed to be concentrated during the actual calving period, for the remains found were those of animals which were very young. Eight of the carcasses were found on the winter range which the majority of the elk leave before and during the calving period.

It is extremely difficult to determine what proportion of the calves are found as carrion and how many are killed by coyotes. In domestic animals we know that there is a mortality among calves at birth and shortly after birth. In wild animals we know less about this type of mortality, but we 


\section{Ecology of the Coyote in the Tellowstone}

do know that there is a definite mortality at birth. In the spring of 1936, I found a calf moose about 2 or 3 days old which had been seen acting sickly the day before. He was one of twins. The mother was still in the vicinity, so the calf had not been deserted. Under the section on antelope an example of antelope fawns dying at birth is given. Presnall (1938), in discussing effects of an overgrazed deer range, writes: "A weakened condition of the deer has already been indicated in the high death losses during the winter of 1936-37. Also in the summer of 1937 several deaths in parturition were noted.'

In regard to calf elk mortality at birth, O. J. Murie in his publication on the coyotes of Jackson Hole, Wyo., gives several instances of calf mortality in which predators were not involved. He writes: "It was discovered that calves of both elk and moose had been dying shortly after birth, and in the spring of 1931 eight dead elk calves were found, but opportunity was afforded to examine only one of these before decomposition began. While no positive conclusions were reached as to the cause of death, it was determined that natural enemies were not responsible. . . . The fact that eight dead calves were counted in a limited area, and that it is difficult to find such carcasses in timbered country, would indicate that the percentage of loss from this unknown ailment was fairly high."

In the spring of 1938 I made some special search for uneaten dead calves. Obviously, however, such a search is almost futile, for the calving ground is very extensive and even though many calves should die at birth it would be only by chance that a person would find a carcass, especially before coyotes had found and eaten it. The first day I searched for dead calves was on May 24. I found one which had just been born, for parts of it were still moist. The mother was feeding nearby and it was from observing her actions that I was able to find her dead offspring in a clump of sagebrush. This animal appeared to be normal but was rather small, weighing only 20 pounds (considerably below the average weight which is 30 pounds or more), and with the following measurements: total length $34 \frac{1}{2}$ inches, hind foot $13 \% / 8$ inches, ear 14 inches.

On May 28 from the top of a butte in the Horseshoe I saw two ravens fly to a distant spot and alight on the ground. On going to the spot, I observed that they had been feeding on a dead calf elk. The only marks were small breaks in the skin on the back and on the abdomen where the ravens had been feeding. The hair was slipping so that it had probably been dead a week. It was either born prematurely or had developed abnormally. The body was but little thicker than the legs, the carcass probably weighing about 10 pounds. Measurements were as follows: Total length 33 inches, hind foot $12 \frac{1}{2}$ inches. 


\section{Fauna of the National Parks of the United States}

A few days later in Hayden Valley, Assistant Park Naturalist Oberhansley was attracted to the carcass of another calf elk. About half the carcass remained and it had decayed considerably. If killed by coyotes one would expect that it would have been eaten before any decay had set in, so it seems that this is another record of a calf that had died at birth.

The hard winters may increase the death rate of calves, since it has been found in studies of domestic animals that deficiencies in nutrition cause abortions and weakened calves. Furthermore, contagious abortion has been found in the elk so that some calves may be lost as a result of this disease.

In Jackson Hole O. J. Murie found each winter a few aborted calves. I have frequently seen coyotes in late winter among the elk herds and think it probable that the coyotes are attracted by the chance of finding an aborted calf or a carcass of an old animal. O. J. Murie writes about contagious abortion as follows: "Field observations, however, supplemented these tests, and each winter a number of aborted fetuses were found-10 or more being found in one winter. Considering that such fetuses are not readily found and that ravens often do away with the remains in a short time, it seems safe to conclude that a considerable number of abortions occur. An employee at the elk refuge observed one, but when the fetus was sought later in the day, it had disappeared. . . . One cow examined had died of necrotic stomatitis. Only a few feet behind her lay the aborted fetus." In certain cases the elk calf remains found in droppings might represent fetuses found by coyotes in dead cows, for some of the cows dying in the spring carry fetuses. Also some cows may die during the trials of labor and leave a calf to die.

Besides the calves dying at birth a few are no doubt occasionally lost accidentally or possibly at times are deserted. On May 27, 1938, Assistant Park Naturalist Oberhansley and I found a calf elk in a badger hole a few feet from where I had seen the animal the previous day. One leg was straight out behind in the hole in such a position that it did not seem probable that the calf could extricate itself unassisted. When we stood it up, its hind quarters quivered and it walked as though quite weak. This calf might have become carrion for coyotes if we had not happened along to help it.

On May 28, 1937, a band of 95 elk were following the Lamar River looking for a place to ford. As the river was high, the elk were hesitant in crossing. A cow some distance to the rear was followed by a wobbly calf, which kept lying down after following 10 or 20 yards at a time. The cow wanted to move forward with the herd. She looked alternately toward the 


\section{Ecology of the Coyote in the Tellowstone}

herd and the calf until a group of five cows passed her on a trot. Following them, she joined the main herd one-third of a mile from the calf. The cows finally crossed the swollen Lamar River and it was not known if the mother returned to her offspring. The herd instinct and the migration habit were pulling strongly, and in this case it seemed that the calf may have been deserted although desertion of young is probably a rare occurrence.

There is a natural calf mortality at birth, and although there are relatively few records, those existing seem to be sufficient to indicate that a number of dead elk calves are available on the range as carrion.

\section{MATERNAL PROTEGTION}

To GaIN some measure of the potential coyote predation on calves an attenipt was made to learn what opportunities a coyote might have for preying on them. The watchfulness of the cows with young and their action when coyotes were near were observed.

The calving period extends from the middle of May to about the middle of June. In 1937 the first calf was found on May 15 and the last newborn on June 18. In 1938 the first young was not found until May 23. The majority of the calves are probably born during the last few days in May and the first week in June, during the period in which the elk are migrating from winter to summer range. Many of the calves are born on the winter range, but more of them do not arrive until the cows have reached the summer range. Cows drop out of the traveling bands and go off by themselves to give birth to their calves. Many of them go to the open sagebrush and in a few days, when a calf has become strong enough to travel, the mother moves off with it to join any band of elk that happens to be moving past. As early as June 1, I saw eight calves traveling easily with eight cows which were moving at a brisk trot. In the Horseshoe and at the Buffalo Ranch bands of 50 to 100 elk were often seen resting near the edge of the trees while one or more lone elk would be out in the sagebrush, each with a calf. As the calves are brought into a herd a few days after birth, they have the benefit of the general protection offered by the band.

On May 25, 1938, at 9:30 a. m., an elk calf was seen in the sagebrush 15 yards from some scattered Douglas firs on the fringe of the woods. While I was watching the calf, it stood up, apparently to stretch, and lay down on its other side. It was still in the same spot at $2 \mathrm{p} . \mathrm{m}$. No cow was seen, but one may have been resting in a nearby grove of trees. Calves lying alone do not stay perfectly still but occasionally stand up for a minute or two. This movement of the calves increases their exposure to predators, but the duration of the movement is probably too brief to add appreciablv to the 


\section{Fauna of the National Parks of the United States}

insecurity. Even if a coyote should see a calf, the mother would generally be near enough to protect it.

Some observations were made which indicate that mothers remain close to their calves for several hours after birth and later stay near them. On May 25, 1938, at 10 a. m. a cow and newly born calf were seen in a clump of aspen. Fresh blood on the ground showed that the calf had been born that morning. The calf seemed barely able to rise but did so several times during the hour that I watched, and three times appeared to be nursing. After walking 7 or 8 yards to the edge of the grove, it would wander back to lie beside its mother. At 2:30 p. m. the cow and calf were still in the aspen grove. When the cow scented me, she tried to entice the calf to leave with her, but the calf was so attached to the grove that, after moving a few yards beyond its edge, it would return. This would cause the cow to return to the grove, and as she trotted off again the calf would follow a short distance but then retreat. The procedure was repeated several times. Finally the calf moved some distance from the grove and, after further coaxing by the cow, followed her on wobbly legs. The calf lay down in a hiding posture when I approached and the cow ran into the woods a short distance, returning almost at once when the calf cried as I lifted it.

On May 26, 1938, another cow was seen lying beside her calf on an open slope of Specimen Ridge, a little below a band of 60 feeding elk. When I was 40 yards away, the cow ran off with the band but was lying with her calf again an hour later. With head up, the calf watched me approach and was unafraid when I stroked it.

On May 28, 1938, in the Horseshoe, a lone cow was lying down in the sagebrush. In about 15 minutes she looked over her back toward her calf which had stood up 25 yards away and was walking unsteadily toward her. She met the calf, which nursed for about 5 minutes. The cow then walked off 20 or 30 yards to feed and the calf followed a few yards and lay down,

In the Horseshoe on May 29, 1938, a cow after grazing, lay down about 25 yards from her calf. This calf was tame and docile and would not bear its own weight at once when I stood it up. Young but apparently strong, it started up the gentle slope toward the aspens about one-third of a mile away where its mother stood watching. It lay down after traveling about 100 yards but got up again when it saw me coming. Seeing her calf approach, the mother trotted toward it a couple of hundred yards and two other cows followed her. When the three cows met the calf they all smelled of it and then turned up the slope, the calf trotting close to its mother. One of the cows struck at the calf, but I doubt if she intended to touch it. Often when a calf is thought to be in danger, one or more cows have been seen to 


\section{Ecology of the Coyote in the Yellowstone}

join the mother and act as solicitous for the safety of the calf as the mother. On May 26, 1937, I found a calf just born, and while examining it was approached by the mother and nine other cows all excited and worried. They advanced and retreated several times.

On May 29, 1938, a calf lay near the highway at Tower Falls. All day the cow remained in the vicinity, afraid to cume to her calf because of the traffic on the road, but at dusk she returned to it.

On May 31, 1938, at the Buffalo Ranch several observations were made showing that the cows remain close to their young calves much of the time. A calf followed a cow 25 yards and then walked off to the side another 25 yards and lay down. The mother fed within 50 yards of this calf for the half hour that I watched her and frequently looked toward her offspring. Another cow was feeding near her calf which had stood up to wander around in a patch of sagebrush, later joining the mother to nurse, and then alternately walked and trotted after its mother as she moved off about 100 yards. Another cow was seen lying down beside its calf for an hour, and still another was lying 30 yards from its calf which was resting on a patch of short bright green grass. On June 2, there were a dozen single cows in the sagebrush in the Buffalo Ranch area, each looking after her calf.

Most of the observations which were made indicate that the cows remain close to the calves before they join the moving bands. Occasionally a cow is not seen near a calf, but usually there is a possibility of the cow being in a position to watch it. Some observations made June 4, 1938, are a little different from most of those cited above. However, proximity of the road to the calves may have had some bearing on the actions of the elk in this case. I spent the day watching the behavior of antelope does immediately east of Trumpeter Lake. Near the top of a butte I noticed 2 elk calves lying about 2 yards apart. Although they had been there at least since 9 a. m. when I had begun to watch, I did not see them until $11 \mathrm{a}$. $\mathrm{m}$. when 4 cows came on the slope below. Then one of the calves stood up, stepped around a bit and lay down again. One of the cows walked up within 50 yards of the calves, but after peering at them for a few minutes returned to feed with the 3 other cows. When the calf stood up all the cows as well as 3 antelope watched it. These cows left at 11:45 a. m. and I am not sure that the calves belonged to any of them. During the day the calves each stood up twice to my knowledge and possibly did so at other times when I was looking elsewhere. At 5:45 p. m. 3 cows appeared from over the rise to the north and fed slowly toward the calves, coming to them at 6:10 p. m. The calves came forward about 5 yards and met their respective mothers and nursed for 8 minutes. The third cow which appeared heavy with

$193098^{\circ}-40-5$ 


\section{Fauna of the National Parks of the United States}

calf stood between the other two families, looking around. At 6:30, the three cows and two calves moved west and at 7 they reappeared and went down the east slope feeding. Although no cows were seen near the calves during the day, except the four below them in the morning, it is possible that the mothers were out of my sight over the ridge but within view of the calves. Also, the road passing near the base of the butte on which the calves were resting may have kept the cows away during the day.

The mother elk protects its calf vigorously and with courage. O. J. Murie saw a cow chase a dog which had accidentally come near the calf and miss the dog by inches when it struck. Some observations on the behavior of elk and coyotes in Yellowstone are set forth to show that coyotes are little tolerated near the calf. Sometimes even antelope and other cows are driven away from the vicinity of the calf.

On May 30 in the Horseshoe, a lone cow galloped 100 yards after another cow which was passing 30 or 40 yards distant.

On June 2, 1938, at the Buffalo Ranch, two different cows with calves were seen chasing another cow, and one chased two antelope. Usually the antelope are not molested in this way nor are other cows.

On May 27, 1938, on a flat along Slough Creek, a cow chased a coyote about 150 yards, following it with evident determination. Near the edge of the open flat, the cow made a small circle back of the coyote and pursued it across the flat again. The coyote dodged the cow two or three times and disappeared in a grove of cottonwoods along the creek.

June 1, 1938, on the upper part of the Buffalo Ranch, I observed three coyotes traveling loosely together over the open sagebrush range. There were antelope alone and in small bunches, and several single elk, each with a calf, standing out in the sagebrush. I first noticed the coyotes at $10 \mathrm{a} . \mathrm{m}$. moving about 100 yards apart, stopping here and there on their way to investigate smells and occasionally to pounce on a mouse. The coyote in the lead came near a buck antelope which advanced toward it, circling up to within 15 yards and shaking his horns. The buck stopped and the coyote trotted on his way. Two of the coyotes reached a marsh and waded through the water which was about 6 inches deep. On the margin of the marsh at least one mouse was captured. The third coyote followed an old river bank a little to one side of its two companions. When it came within 60 yards of two doe antelope it circled around them. The antelope, which appeared heavy with young, watched the coyote part of the time it was passing around them and advanced toward it when it cut back to its original course after passing them. All three coyotes went down the flats about one-third of a mile. One of four separate elk standing in an area of closely browsed 


\section{Ecology of the Coyote in the Yellowstone}

willows advanced about 100 yards toward the approaching coyotes and the three other cows moved forward a few yards. About 75 yards from the first elk, the coyotes, after tarrying a few minutes, reversed their direction and started weaving their way up the valley again along a course a few hundred yards nearer the edge of the woods. At one o'clock, after the coyotes had gone out of sight up the valley, the cow which had approached the coyotes walked about one-third of a mile and joined a calf that had been lying, as near as I could determine, about 30 yards to one side of the course taken by the three coyotes in passing up the valley. It is rather surprising that this cow did not become worried when she saw the coyotes pass so near her calf. The coyotes went out of my view at 12:15. Near the same spot 15 minutes later a band of eight antelope were seen advancing alertly toward a coyote. They followed it while it hunted mice, and then began to feed as it continued to hunt through the sagebrush. A cow elk looking over her back watched the coyote and, while it was still about 300 yards away, arose and walked toward it with ears cocked rigidly forward. Fifty yards from the coyote the elk started after it on a dead run, causing the coyote to exert itself to keep out of reach. The cow then lay down and was there $1 \frac{1}{2} 2$ hours later when I again passed by. Apparently she had a calf near her. These coyotes seemed to be hunting mice primarily.

On June 2, 1938, I returned to the Buffalo Ranch and made some more observations. At 9:30 a. m. a lone cow was watching a coyote 200 yards away hunting mice. The cow walked toward it and when 15 or 20 yards distant she dashed after it, driving it to the north. The coyote continued about 250 yards farther and after hunting mice for 10 minutes, and rolling on the ground, returned in the general direction of the watchful cow, but to one side of it. The cow walked toward it and when within a few yards, made a rush, which the coyote easily avoided. The cow circled and made another run at it, chasing it once around in a small circle perhaps 10 yards in diameter. She then followed the coyote as it moved off again to the north. A half hour later the first cow was seen wandering up the gentle slope but in a few minutes returned at a fast walk after the coyote which was moving again southward. She then nuzzled her calf which had been lying near the spot where she had been resting and from which she had chased the coyote. The latter wandered off in the sagebrush where I lost sight of it.

The observations made indicate that the cows remain quite near the calves and that the mothers keep a close watch for coyotes and drive them away.

\section{CALF SURVIVAL, 1937}

Classified counts were made of elk whenever an entire band could be counted in order to get some idea of the calf increase in proportion to the 


\section{Fauna of the National Parks of the United States}

cows and yearlings. The figures are not extensive but represent a fair sample. The percentage increase of calves in various bands is uniform considering the great chance there is for variation. My calf ratio is higher than that obtained by Rush (1932) between 1928 and 1931, from counts during the months of January, February, March, and April. His figure, converted so as to be comparable, is 25 percent and mine is 41 percent. The lower percentage of calves recorded by Rush may in part be due to the fact that his counts were made during the winter period when a relatively higher mortality occurs among calves. Summer counts made by O. J. Murie (1935) in Teton National Forest just south of Yellowstone National Park resulted in 1,192 cows and 458 calves, or a calf increase of 38 percent.

Elk Calf Survival, 1937

\begin{tabular}{|c|c|c|c|c|c|}
\hline 1937 & Location & Cows & Calves & Bulls & $\begin{array}{l}\text { Calf-cow } \\
\text { ratio }\end{array}$ \\
\hline & & & & & Percent \\
\hline June 1 & Turkey Pen ........... & 8 & 8 & & 100 \\
\hline June 13 & Trumpeter Lake ........... & 50 & 25 & . & 50 \\
\hline June 28 & Slough Creek. . . . . . . . . . . & 97 & 22 & & 22 \\
\hline \multirow{4}{*}{ July 12} & $\ldots \ldots$ do $\ldots \ldots \ldots \ldots \ldots \ldots$ & 140 & 69 & & 49 \\
\hline & Hayden Valley........... & 38 & 14 & & 36 \\
\hline & $\ldots$ do $\ldots \ldots \ldots \ldots \ldots \ldots$ & 40 & 15 & & 37 \\
\hline & $\ldots \ldots$ do $\ldots \ldots \ldots \ldots \ldots \ldots$ & 103 & 48 & & 46 \\
\hline \multirow[t]{7}{*}{ Sept. 27} & Pelican Valley. . . . . . . . . . . . . & 4 & 3 & 1 & 75 \\
\hline & $\ldots \ldots$ do $\ldots \ldots \ldots \ldots \ldots \ldots$ & 7 & 2 & 1 & 28 \\
\hline & $\ldots$ do $\ldots \ldots \ldots \ldots \ldots \ldots$. & 12 & 7 & 1 & 58 \\
\hline & $\ldots$ do................. & 16 & 7 & 1 & 43 \\
\hline & $\ldots \ldots$ do $\ldots \ldots \ldots \ldots \ldots \ldots \ldots \ldots$ & 6 & 1 & 1 & 16 \\
\hline & 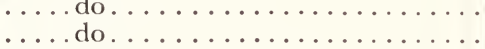 & $\begin{array}{l}1 \\
9\end{array}$ & $\begin{array}{l}0 \\
1\end{array}$ & 1 & $\begin{aligned} 0 \\
11\end{aligned}$ \\
\hline & 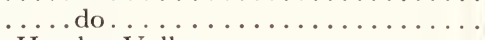 & 9 & 3 & 1 & 33 \\
\hline \multirow{2}{*}{ Do. } & Hayden Valley................. & 6 & 2 & 1 & 33 \\
\hline & $\ldots \ldots$ do $\ldots \ldots \ldots \ldots \ldots \ldots \ldots \ldots$ & 4 & 2 & 1 & 50 \\
\hline $\begin{array}{ll}\text { Nov. } & 4 \\
\text { Nov. } & 6\end{array}$ & $\begin{array}{l}\text { Soda Butte................... } \\
\text { Horseshoe }\end{array}$ & 16 & 6 & 1 & 37 \\
\hline Nov. 7 & Swan Flats. . . . . $\ldots \ldots \ldots \ldots \ldots$ & 23 & 8 & & $\begin{array}{l}67 \\
34\end{array}$ \\
\hline Nov. 11 & Blacktail. . . . ............ & 64 & 26 & & 40 \\
\hline \multirow{3}{*}{ Nov. 14} & $\ldots$. do $\ldots \ldots \ldots \ldots \ldots \ldots \ldots \ldots \ldots$ & $\begin{array}{l}7 \\
3\end{array}$ & 5 & & 70 \\
\hline & 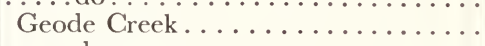 & 117 & 40 & 3 & 34 \\
\hline & 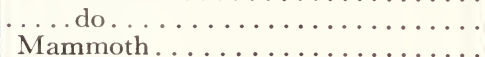 & $\begin{array}{r}16 \\
6\end{array}$ & $\begin{array}{l}6 \\
4\end{array}$ & 1 & $\begin{array}{l}37 \\
66\end{array}$ \\
\hline \multirow{4}{*}{$\begin{array}{l}\text { Nov. } 15 \\
\text { Nov. } 20\end{array}$} & Blacktail. . . . . & 53 & 21 & 6 & 39 \\
\hline & $\ldots$. do................ & 7 & 3 & $\cdots$ & 42 \\
\hline & & & & & \\
\hline & Total. . & 931 & 385 & 22 & 41 \\
\hline
\end{tabular}




\section{Ecology of the Coyote in the Tellowstone}

THE high survival of calves in 1937 indicates that coyotes were not getting many. No good calf counts were made in 1938 but I suspect the crop was lower than in the previous year because of the hard winter of 193738 , which resulted in the cows becoming abnormally thin and weak. Their condition was poor during the last months of the gestation period and during calving time.

\section{STATUS OF ELK}

The elk population in Yellowstone Park is unquestionably too large, resulting in a severely overbrowsed winter range. The depleted range is harmful to the elk but even more harmful to the deer, antelope, and bighorn over whose ranges the elk wander and with whom they compete directly for food. The elk herd could safely suffer a loss of two-thirds of the present number, with benefit to the other ungulates, the ranges in general, and to the elk themselves. In an effort to improve the situation a program of elk reduction was inaugurated by the National Park Service in the winter of 1934-35.

All available data indicate that the coyote is a minor factor in the status of elk. Although the latter on the big game winter range on the north side of the park make up the bulk of the winter food supply of the coyote, it is in the form of carrion and little if any predation on elk exists at this season. During the calving period a few youngsters may be eliminated by the coyote but the data indicate that the calves eaten probably are largely carrion. Since there are now too many elk on the winter range occasional coyote predation on the calves would not be harmful to the welfare of the elk population. 


\section{Chapter VI}

\section{MULE DEER IN RELATION TO GOYOTES}

$\mathbf{R}^{\text {ECAuse fear had been expressed that coyote depredations on mule deer }}$

$\mathbf{B}$ (Odocoileus hemionus macrotis), especially in winter, were so extensive that the future of the species in Yellowstone was threatened, I devoted much of my time during the winter of $1937-38$ to a study of factors affecting the deer. Their food habits were studied in considerable detail, their range was carefully examined, competition of other ungulates noted, condition of deer watched, fatalities recorded and their causes and the age and sex of the dead animals determined when possible. Fawn survival through the winter was tabulated, coyote depredations noted, and general relationship between deer and coyotes was observed. Since the status of several other species was also involved and had to be studied, time did not permit me to go into details to the extent desired.

\section{WINTER RANGE}

Most of the deer winter on the north side of the park in the following localities: Reese Creek, Game Ranch, lower reaches of the Gardiner River and Lava Creek, and along the Yellowstone River from Gardiner to Tower Falls. A few deer are found at Old Faithful, Norris, and occasionally at other isolated spots such as Cache Creek and Canyon. In 1937-38 deer were absent from some areas around Hellroaring Creek where they had wintered the previous year. The heavy crust on the snow in 1937-38 no doubt tended to restrict the winter range while the loose snow in the winter of 1936-37 had permitted the deer to spread out more freely. The deer move from the interior of the park to the winter range in the latter part of November and return in late May.

\section{DEER AS COYOTE FOOD}

DURING the winter, deer (in the form of carrion) furnish a varying supply of food for the coyotes. In some years rather heavy mortality among deer due to malnutrition and disease has been reported, while in other years the mortality has been light. In the latter part of the winter some fawns, chiefly the weaker ones, are killed by coyotes. Deer remains were found 


\section{Ecology of the Coyote in the Yellowstone}

in 64 droppings gathered between March and November but many droppings noted in winter which were not recorded contained deer hair.

\section{GENERAL CONDITION OF DEER, WINTER OF 1937-38}

WILD populations are heir to a variety of ailments; they are subject to parasites, diseases, accidental crippling, and general debility due to old age, or malnutrition resulting from unfavorable winter range. The extent to which a population is affected has, of course, a direct bearing on the amount of carrion which may be available to flesh eaters, and probably also has a bearing on the extent of predation. So before tabulating the dead deer which were found I feel it worth while to give a general picture of the health of the deer by listing observations which were made during the winter of $1937-38$.

Because conditions were specially unfavorable to deer over part of the range in the winter of 1937-38 as a result of crusted snow, the condition of the deer was perhaps worse than usual. By spring they were all poor. Fawns, especially, became thin and weak, and some of the aged animals lost flesh until the skin hung closely to the skeleton.

1937

September 29 . A piece of skin and flesh 4 inches across hung from the fore shoulder of a fawn. The animal limped badly. It was in the road at Mammoth and had probably been struck by a car.

November $21 \ldots$ A medium-sized buck above Mammoth Terrace had a pronounced limp in a front leg.

1938

January $15 \ldots$ Near Gardiner a young buck was dragging a front leg. The animal was killed by a ranger March 26.

January $16 \ldots$ Near Gardiner a doe had a decided limp on a front foot.

January $20 \ldots$ In the park, near Deckers Flat, two does were seen, each lame on a front foot. They may have been wounded during the elk hunting season. In the same locality a lone fawn was observed with a right hind leg hanging useless, apparently due to shot.

January $27 . .$. Between Gardiner and Game Ranch a doe was seen traveling on three legs.

February 1... On Reese Creek, a doe had a hind leg swinging. While going under a short piece of old fence, she slipped and slid down the hill several feet.

February $8 \ldots$ A fawn along the Gardiner River had much of the hair missing from its throat. This was probably due to ticks.

February $12 \ldots$ A doe was seen with most of the hair missing from the right side of the face.

February 13.... On Lava Creek near Undine Falls I found some soft deer droppings. The food was but slightly digested; entire fir needles and pieces of 


\section{Fauna of the National Parks of the United States}

1938

cedar an inch long were noted in the scats. I followed the tracks over a rise and came upon the deer, a buck carrying a huge set of antlers, but an extremely thin animal, the hide clinging close to the backbone and the hips protruding prominently. The buck appeared listless.

February 16.... Ninety deer were seen along the Yellowstone River between Blacktail Creek and Little Cottonwood Creek; many of them appeared thin. From inside the thigh of a large buck seen on Little Cottonwood, a large piece of skin was hanging. It was a fresh accident, blood appearing in his bed and along the trail leading back to some rocks and cliffs. There were no coyote tracks. Possibly the buck had slipped and hurt himself in the rocks. Blood noted in tracks of several deer indicated that their legs had been cut by crusted snow.

February $22 \ldots$ A fawn near the Gardiner River had a rough coat and looked thin and weak.

March 5..... Along the Yellowstone River and a little below Cottonwood Creek, I saw a lone fawn that was extremely emaciated. The backbone and shoulder blades were unusually prominent.

March 7..... An old doe was found below Boiling River so weak that she was barely able to rise.

March 9..... A doe had a drooping ear and held her head to one side as though something ailed it. Most of the hair on the under side of the necks of two bucks was missing.

March 17..... Thirty deer were observed along the Gardiner River for about an hour. Most of them had a ragged appearance and apparently were heavily infested with ticks. At intervals the majority of the deer were licking or biting various parts of the body. Two bucks had struck up a partnership; one chewed on his companion's throat, while the owner reciprecated by chewing on the other's shoulder. This mutual scratching was continued for 15 minutes and, after an interval, resumed. A young doe had a sore about $1 \frac{1}{2}$ inches across above the tail and on one side of the backbone. A large buck was exceedingly thin. A doe chewed vigorously on a rag which protruded about 3 inches from the corner of her mouth. The rag was apparently stuck in her cheek, for she was unable to dislodge it.

March 19..... Along Yellowstone River below Crevice Creek an extremely thin fawn was seen across the river. He tottered and stumbled in endeavoring to walk. This fawn no doubt died within a few days. At Crevice Creek two weak fawns were seen, one of which I captured and autopsied.

March 22..... On Lava Creek a fawn was so lame on a hind foot that it could proceed only slowly. Several of the fawns observed on this date appeared thin and low-spirited. An extremely thin buck was seen.

March 25..... A doe had four or five sores the size of half a dollar scattered over her side. It appeared that she had been gnawing at the sores. Possibly the latter had been started by biting irritations due to ticks.

March 27..... A fawn and doe near Gardiner appeared emaciated; another doe and two yearlings were also thin. 


\section{Ecology of the Coyote in the Yellowstone}

March $29 \ldots$. . For the past 2 weeks, during which time there had been considerable fresh snow covering the new green grass, the deer have become noticeably thinner; many are very thin.

A doe was seen with patches of hair missing from the flanks.

A fawn was observed near Mammoth limping on a front foot.

April 1....... Along the Yellowstone River below Cottonwood Creek, three does appeared, all extremely thin.

A fawn, extremely emaciated, was noted below Deckers Flat. A fawn was found lying alone one-fourth mile from any other deer. He apparently was ailing and not feeling well enough to move with the band.

April 2....... Along the Yellowstone River, a little below Junction Butte, one buck observed was extremely thin and three others were thin. A fawn was also scrawny, and sluggish in its movements. A doe licked over its body assiduously, until its hair was stuck together.

April 5 ...... A fawn along the Gardiner River had a scratch on one side reaching from the shoulder blade to the hip. A thin buck was seen with a fold of skin hanging under the throat from near the base of the jaw. A doe along the Gardiner River had a swelling on a hind leg reaching from the dew claws to the calcaneum. A thin, runty fawn was noted.

April $21 . .$. . Saw a doe up along the Gardiner River with a severe limp in a hind leg. Another doe limped on a foreleg. A gaunt old buck was seen along Gardiner River. Several of the old bucks were extremely thin. At Mammoth, I found an emaciated buck which was barely able to rise. He walked and trotted a few yards and fell, completely exhausted. I killed and autopsied the animal. The teeth were worn to the gums and there were 50 bots of all sizes in the gular pouch. When stuck, the animal bled very little and the blood coagulated almost at once. A fawn was seen which was snuffling a good deal.

A lone doe along Lava Creek, was extremely thin and listless.

April 26...... Bctween Hellroaring and Blacktail, 102 deer were seen, many of which appeared very scrawny.

April 28..... Many of the dcer at the Game Ranch looked thin, a doe extremely so. At Tower Falls an old doe, very scraggy, was drooling at the mouth. She had a lump under her jaw. Another doe, also thin, had a lump under her jaw.

May $15 \ldots . .$. . Along the Gardiner River, two extremely emaciated bucks were seen.

\section{DEER MORTALITY, WINTER OF 1937-38}

IN the course of the field work carried on during November 1937, and from January 11, 1938, to June 1938, 57 dead deer were recorded. Three of these deer were still alive when found but were in such a weak state that I was able to catch them and perform autopsies.

Sex and age of dead deer.- In order to learn what part of the population sustained the greatest winter mortality, the age and sex of dead deer were 


\section{Fauna of the National Parks of the United States}

recorded when the information could be obtained. Since the sex of most of the fawns was not determinable, this has not been tabulated for any of them. The 57 dead deer were classified as follows: 2, sex and age not known; 9 bucks (6 very old, 3 in their prime); 5 old does; 3 yearlings (2 males, 1 female); 38 fawns.

As we would expect under adverse conditions, the highest mortality was among the fawns and the old animals. It is significant that among the elk, which are preyed upon little or not at all by any predators during the winter, the heavy mortality likewise falls among the calves and the old-age group. It is, therefore, apparent that the weak animals die during the winter, regardless of the activities of predators.

Mortality by months. - The does and fawns, and the bucks to a lesser degree, approach the winter in good flesh. The rigors of winter gradually reduce the stamina of the animals, the rate of reduction depending upon the condition of the range and the severity of the winter, especially the condition of the snow. If the winter is severe the weaker animals begin to die as their vitality is sapped. Many may live until late winter and early spring before succumbing. Most of the population usually survives and recuperates with the advent of the new spring forage. Diseases such as necrotic stomatitis may kill off some animals in good flesh and possibly predators may take a few strong animals, so that all winter deaths are not necessarily due to malnutrition. It must be remembered, however, that malnutrition is often the fundamental cause of mortality brought about by other agents.

The number of dead deer found during each month is as follows: November 1937, 2; December 1937 (no observations made but apparently mortality light); January 1938, 9; February 1938, 12; March 1938, 15 (one poached in March not tabulated); April 1938, 17; and May 1938, 1.

The figures are too small to be conclusive but some correlations appear which are at least suggestive. The winter range along the Yellowstone River between Deckers Flat and Tower Falls is decidedly poorer than the range between Lava Creek and Reese Creek, and the difference was accentuated in 1937-38 by heavily crusted snow, as explained elsewhere. A tabulation of the deaths, according to months, for each of the two ranges, follows:

\begin{tabular}{l|r|r|r|r|r|r|r}
\hline & Nov. & Dec. & Jan. & Feb. & Mar. & Apr. & May \\
\hline Yellowstone River Range ........ & 1 & $\ldots .$. & 8 & 4 & 10 & 5 & 0 \\
Lava Creek-Reese Creek Range.. & 1 & $\ldots$. & 1 & 8 & 5 & 12 & 1 \\
\hline
\end{tabular}




\section{Ecology of the Coyote in the Tellowstone}

The low figure for the dead deer found along the Yellowstone River in February does not give the true picture for it was obvious that 7 of 9 deer found on this range on the 4th, 5th, and 6th of March had died in February so that the figure for the Yellowstone River range should actually be 11 deer for February and 3 for March. The correlation to which I wish to call attention is an early relatively high mortality in the more severe range along the Yellowstone River and a late relatively high mortality on the more favorable winter range between Lava Creek and Reese Creek. The figures indicate that the mortality began earlier on the poorer range and dropped considerably in late March and April. By the time these latter months had been reached most of the susceptible deer (the fawns) had succumbed on the poor range. On the other hand, mortality on the better range did not begin until later, when the vitality of the animals had been gradually reduced, thus resulting in a late winter mortality. If the coyote preys extensively on strong healthy fawns, the correlation pointed out is not so significant for there were some early coyote kills along the Yellowstone River. There is, however, some evidence as will be pointed out elsewhere, that strong fawns may not be highly susceptible to coyote predation. In reviewing these figures it must be remembered that there is a good deal of chance connected with the finding of the carcasses and that consequently dates of discovery of the carcasses may not be a true index of the time the animals died. My general impression from observing the condition of the deer and the range conditions during the winter, however, is that the above correlation, showing a higher early mortality on the poorer range, is a true picture of the course of events.

Causes of winter mortality.-Autopsies were made, when possible, but in many cases insufficient remains were present to give indication of even a generic cause of death. Early in the winter most carcasses were rapidly cleaned up by coyotes so that it was difficult to determine the animals that had been killed by them and those which had died from other causes. Later in the winter, carcasses were not cleaned up so quickly and there was then some evidence to account for death in a general way. Before discussing in further detail the various causes of mortality it might be well to give the following summary: Malnutrition and disease: 1 buck, 2 yearlings, 9 fawns; old age: 6 bucks, 4 does; coyote predation: 8 fawns; fractured leg: 1 yearling, 1 doe, 1 young buck; fighting: 1 buck; struck by car: 1 fawn; run down and killed by myself for examination: 1 fawn; killed by poacher: 1 fawn. The cause of death of 18 fawns and 2 deer of unknown age and sex could not be determined because only fragmentary remains were present. Death may have been due to coyote predation, disease, malnutrition, or a combination of factors. 


\section{Fauna of the National Parks of the United States}

When it was evident that coyotes had not killed the deer and that the latter were not aged, death was attributed to malnutrition or disease. Coyote predation as a cause of death of fawns was ruled out when the carcasses were slightly eaten, or untouched, with no evidence of coyote tooth marks. All but four such carcasses were found in April when carrion became abundant because of the many dead elk. Three of the fawns and one yearling were seen on the Yellowstone River range. One yearling had several sores in the mouth indicating presence of necrotic stomatitis. A young buck in his prime which had died on February 8 had a malformed antler which suggested that the animal had been ailing for a long time. All the animals found dead were extremely thin, indicating that malnutrition may have been a primary cause of death in many cases. Although the death of a fawn, discussed elsewhere under the section dealing with coyote kills, was caused by either a car or coyotes, I have attributed it primarily to mechanical obstruction of the nasal passages by 102 nose-fly larvae. Such larvae were discovered in 10 of 21 carcasses in which an examination for them was possible. The larvae were usually found in the gular pouch; in two cases the pouch was completely filled, 52 being found in one case and 51 in another. The 102 larvae in the fawn on February 20 were nearly all about an inch long; 50 in a buck on April 21 were mostly one-half inch or smaller in size, but a few an inch long were also present.

Rush (1932) has reported on 37 post mortems performed on deer in Yellowstone during the years 1929 to 1932, inclusive. The cause of many of the deaths was either directly or indirectly attributed to the presence of botfly larvae, lungworm, lesions due to feeding on foxtail, tapeworms and roundworms, and inflammation of stomach due to overfeeding on cottonseed cake. Of the 37 animals autopsied, 2 deaths were attributed to the coyote, 13 to disease and parasites, 11 were sick and slaughtered for autopsy, 8 were killed and injured accidentally, 2 died from cottonseed eaten too generously, and 2 died from eating garbage. Twenty-nine of the thirty-seven deer were fawns.

I found 6 bucks and 4 does which undoubtedly had died primarily from old age. The animals were very thin and the teeth were worn to the gums and some were missing. Two of these animals were noted before they expired, too weak to rise. Two died in January, 2 in February, 1 in March, 4 in April, and 1 in May. Several extremely thin old animals seen in late April were undoubtedly not far from death. A hard winter probably causes some of the old animals to succumb a year or so earlier than they would under favorable winter conditions. 


\section{Ecology of the Coyote in the Yellowestone}

Tracks in the snow indicated that 8 fawns had been killed by coyotes. These incidents will be described in some detail in a later section. There was no evidence that the coyotes molested any deer except fawns.

A young buck with a broken humerus was killed by a ranger. It is likely that the bone was fractured by a shot or possibly by a fall or collision with a car. The animal was in poor condition. On a steep slope along the Yellowstone River an old doe was found with a double fracture below the calcaneum. Below the breaks the leg was bloodshot; it was evident that the animal had been alive for a time after the accident. There was very little food in the stomach so it had apparently been down for a time before dying. At the foot of a steep slope near Crevice Lake a dead yearling with a hind leg broken a little above the dew claws was found. The leg was swollen below the break. In traveling, especially over talus which in many places along the Yellowstone consists of sharp blocks, one would expect that a broken leg would not be a rare occurrence. Deer were frequently seen limping. Ranger Gammill in his monthly report for January 1935 mentions seeing a doe at the Hellroaring Station during the month with a front leg broken below the "ankle." The leg seemed to be mending, but in a crooked position.

A buck was killed in a fight on November 13, 1937. When retreating from its adversary it had been hooked on the inside of the left hind leg. The mortal wound had been made by a tine which pierced the abdominal wall and severed an artery under the backbone. Deaths resulting from fighting are probably rather rare. Assistant Park Naturalist Oberhansley saw a buck killed in a fight in the park, and Ranger Condon saw two bucks with locked antlers which did not break loose for at least an hour. One of the animals was quite exhausted.

One deer was known to have been killed by a car. Such accidents are occasional.

One of two weak fawns, on March 19, was run down after a rather short chase and killed as it lay on the slope completely exhausted. This fawn probably should be classified as dying from malnutrition or disease for certainly it was too feeble to survive. Three other extremely weak fawns were noted. This incident will be discussed later.

The legs and head of a fawn were found near Bear Creek just outside the park. No doubt deer wandering beyond the park boundaries are occasionally taken illegally. At Deckers Flat, adjacent to the park, during the elk hunting season more than 60 deer were reported shot illegally and some persons thought the figure much higher. Some of the deer in this locality spend part of the time within the park boundaries. 


\section{Fauna of the National Parks of the United States}

Mortality among the deer varies from year to year, depending on various factors. Ranger Rudolf Grimm, during the winter of 1935-36, found more than 30 deer which had died from disease in a restricted area on the Game Ranch. A trapper told me that during the same winter many deer had died in the Gardiner-Jardine area.

\section{FAWN SURVIVAL}

An effort was made to determine the number of fawns which were surviving in order to learn: (1) The status of the deer population, that is, whether it appeared that enough fawns were surviving to maintain the species; and (2) if there were any correlation between the condition of a unit of the range and the number of fawns surviving on it.

After the deer had moved into the winter range in 1937-38 there was no noticeable shifting about from one unit of the range to another, even though there is continuous winter range between some of the units. On the contrary, the deer seemed restricted to relatively small areas. Approximately the same number of deer were always found in certain draws, and individual deer that I could recognize were found frequently in the same locality. For instance, a horned doe remained in the vicinity of Junction Butte the year round. She was seen there by Ranger Condon in the winter of 1936-37, and in the fall of 1937, early spring of 1938, and early spring of 1939 by myself. On February 5, 1938, near the mouth of Blacktail Deer Creek I saw a doe with the top half of both ears missing. Ranger Gammill saw this doe in the same area on March 28 almost 2 months later. Six counts of deer in the open areas below Deckers Flat between February 17 and April 1 varied from 40 to 48, indicating a stable population. These deer were usually concentrated around two draws a few hundred yards apart. During most of the winter the home range of some of the deer probably did not cover an area much more than a mile across, others possibly ranged more widely. The deer tabulated for the various units on the winter range were on the whole restricted to that particular unit all winter. Any movement that there might have been would not be sufficient to make an appreciable difference in the figures.

At first some attempt was made to segregate the yearlings but as differentiating them was difficult and often there was not time to classify them, they were finally grouped with does and bucks. All the animals were classified into three groups, does (including yearling does) bucks, and fawns. The fawns were usually readily distinguishable by a combination of characters, including small size, short rostrum, marked facial pattern, 


\section{Ecology of the Coyote in the Yellowstone}

and general darker color, but by spring some of these characters were not so distinctive and occasionally a few animals were seen which had to be scrutinized carefully to determine their age. Size as a criterion is deceptive so that yearling does sometimes appeared to be adults and in the distance yearlings sometimes looked like fawns. After some experience with the difficulties involved the likelihuod of errors in making fawn identifications became small.

Because some of the bucks spend the winter higher than the does, in the deeper snow and among the trees on the fringes of the winter range where they are not so easily counted, it is certain that the bucks are not represented in the counts in their true proportions. But even after making a most generous allowance for uncounted bucks there still seemed to be about twice as many females as males in the population. The lower number of bucks may be due in part to the fact that bucks enter the winter in poor condition from rutting activities. Fighting, resulting in a few casualties among the bucks and possibly a number of injuries which have some permanent weakening effect, may be a minor factor in reducing the buck population.

Since figures for the fawn-doe ratios on the different range units are comparable, percentage of fawn increase is given in terms of the doe counts. Buck counts are not included in these calculations because of their probable variability over the various range units. The tabulations made in the winter of 1937-38 are based on a sample which includes more than 800 of the 1,000 or more deer on the winter range. Because there is sometimes considerable variation in the fawn ratio in various bands, small samples are apt to be misleading.

Winter of 1936-37.-My data on the survival of fawns during the winter of 1936-37 are not extensive but bear out observations made by others. On May 7, 1937, before deer had begun to leave their winter ranges, I observed along the Yellowstone River between Hellroaring Creek and the mouth of Blacktail Deer Creek 10 does and 8 fawns. The percentage of fawns in the sample of the population seen may have been considerably higher than the true average but indicated a good winter survival. This was on poor range where, in the following hard winter of 1937-38, scarcely a fawn survived. Ranger Raymond West, who spent some time in the area during the winter, observed that nearly every doe was followed by a fawn. Ranger Dave Condon, who watched deer closely at Tower Falls, also reported a high fawn survival. During the entire winter of 1936-37 the snow was loose and crustless, a condition highly favorable to the deer, especially on the poor range along the Yellowstone River where the different species 


\section{Fauna of the National Parks of the United States}

of food plants are quite scattered and so entail for the deer considerable moving about to obtain a balanced diet.

Winter of 1937-38. - The winter range was divided into a number of more or less natural units, between which there was very little movement of deer. Counts of deer on these units were made as opportunity offered throughout the winter. The classified counts and the fawn-doe ratio have been tabulated. The counts on each unit of range vary considerably because the deer were not always where they were visible to the same degree, and because it was not always possible to cover the entire unit. In some areas the number of deer seen differed considerably. Especially was this true along parts of the Yellowstone River where the numbers of deer seen in a stretch on different trips varied from 1 to more than 100 . The great variation in counts on this range was due to the fact that most of the inhabited part of it was wooded so the deer were not readily seen but, as snow left the open areas, some deer came out on them to feed and were easily observed.

Classified Counts Made in 1937-38 in Different Range Units

REESE CREEK (GOOD RANGE)

\begin{tabular}{|c|c|c|c|c|c|}
\hline & Doe & Fawn & Buck & $\begin{array}{c}\text { Un- } \\
\text { identified }\end{array}$ & $\begin{array}{c}\text { Fawn- } \\
\text { doe } \\
\text { ratio }\end{array}$ \\
\hline $\begin{array}{l}\text { Feb. } 1,1938 \ldots \ldots \ldots \ldots \\
\text { Feb. } 20,1938 \ldots \ldots \ldots \ldots \\
\text { Mar. } 9,1938 \ldots \ldots \ldots \ldots \\
\text { Apr. } 7,1938 \ldots \ldots \ldots \ldots \ldots \\
\text { Apr. } 20,1938 \ldots \ldots \ldots \ldots\end{array}$ & $\begin{array}{l}46 \\
87 \\
26 \\
2 j \\
77\end{array}$ & $\begin{array}{r}40 \\
53 \\
15 \\
9 \\
33\end{array}$ & $\begin{array}{l}{ }^{6} \\
6 \\
\ldots \ldots \ldots \\
\ldots \ldots\end{array}$ & $\begin{array}{l}{ }^{7} \\
12 \\
\ldots \ldots \ldots \\
\ldots \ldots \ldots\end{array}$ & $\begin{array}{r}\text { Percent } \\
86 \\
60 \\
57 \\
39 \\
43\end{array}$ \\
\hline Total ........... & 259 & 150 & 23 & 19 & 58 \\
\hline
\end{tabular}

GAME RANCH AND VICINITY (FAIR RANGE)

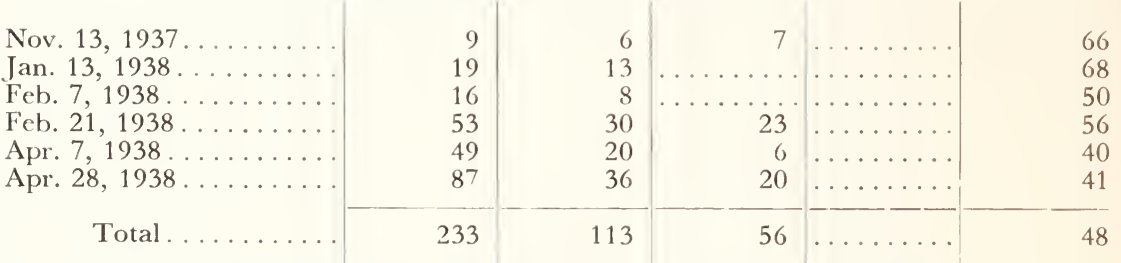

ALONG GARDINER RIVER AND LAVA CREEK (FAIR RANGE)

Jan. 15, 1938

Jan. 24, 1938

Feb. 8, $1938 \ldots \ldots \ldots \ldots$. . .

Feb. 9, 1938

5
20
6
31
44




\section{Ecology of the Coyote in the Yellowstone}

Classified Counts Made in 1937-38 in Different Range Units ALONG GARDINER RIVER AND LAVA CREEK (FAIR RANGE)

\begin{tabular}{|c|c|c|c|c|c|}
\hline & Doe & Fawn & Buck & $\begin{array}{c}\text { Un- } \\
\text { identified }\end{array}$ & $\begin{array}{c}\text { Fawn- } \\
\text { doe } \\
\text { ratio }\end{array}$ \\
\hline $\begin{array}{l}\text { Feb. } 12,1938 \ldots \ldots \ldots \\
\text { Feb. } 13,1938 \ldots \ldots \ldots \\
\text { Feb. } 18,1938 \ldots \ldots \ldots \\
\text { Feb. } 22,1938 \ldots \ldots \ldots \\
\text { Feb. } 23,1938 \ldots \ldots \ldots \\
\text { Mar. } 9,1938 \ldots \ldots \ldots \\
\text { Mar. } 22,1938 \ldots \ldots \ldots \\
\text { Mar. } 25,1938 \ldots \ldots \ldots \\
\text { Mar. } 29,1938 \ldots \ldots \ldots \ldots \\
\text { Apr. } 5,1938 \ldots \ldots \ldots \\
\text { Apr. } 21,1938 \ldots \ldots \ldots \ldots\end{array}$ & $\begin{array}{r}50 \\
29 \\
66 \\
100 \\
37 \\
60 \\
128 \\
40 \\
90 \\
70 \\
154\end{array}$ & $\begin{array}{l}28 \\
20 \\
35 \\
53 \\
19 \\
22 \\
62 \\
30 \\
41 \\
27 \\
59\end{array}$ & $\begin{array}{r}4 \\
9 \\
16 \\
26 \\
2 \\
6 \\
36 \\
8 \\
10 \\
18 \\
59\end{array}$ & \begin{tabular}{l}
\multicolumn{2}{c}{${ }^{2}$} \\
$\ldots \ldots \ldots$ \\
$\ldots \ldots \ldots$ \\
$\ldots \ldots \ldots$ \\
$\ldots \ldots \ldots$ \\
$\ldots \ldots \ldots$ \\
$\ldots \ldots \ldots$ \\
$\ldots \ldots \ldots$ \\
$\ldots \ldots \ldots$ \\
$\ldots \ldots \ldots$
\end{tabular} & $\begin{array}{r}\text { Percent } \\
56 \\
68 \\
53 \\
53 \\
51 \\
36 \\
48 \\
75 \\
45 \\
38 \\
38\end{array}$ \\
\hline Total ........... & 1,002 & 502 & 228 & 35 & 50 \\
\hline
\end{tabular}

ALONG YFLLOWSTONE RIVER BETWEEN GARDINER AND BEAR CREEK (ADJACENT TO PARK)

Feb. 15, 1938 .

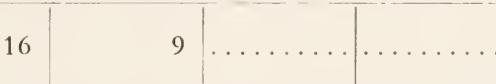

ALONG YELLOWSTONE RIVER BELOW DECKERS FLAT (FAIR RANGE)

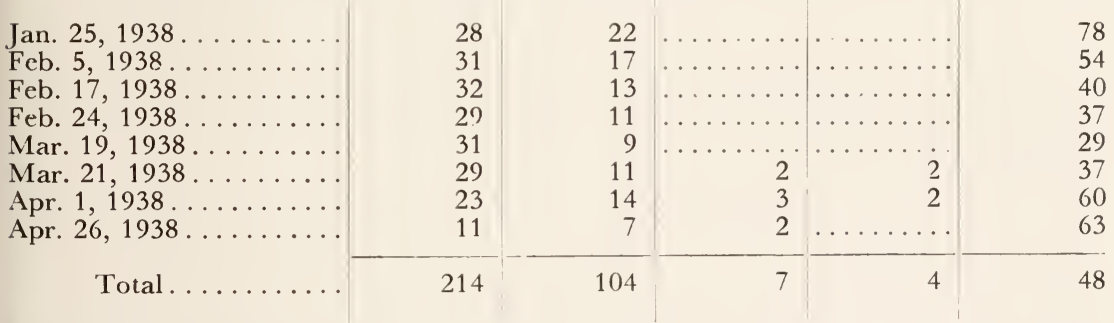

ALONG YELLOWSTONE RIVER BETWEEN DECKERS FLAT AND MOUTH OF BLACKTAIL CREEK (POOR RANGE)

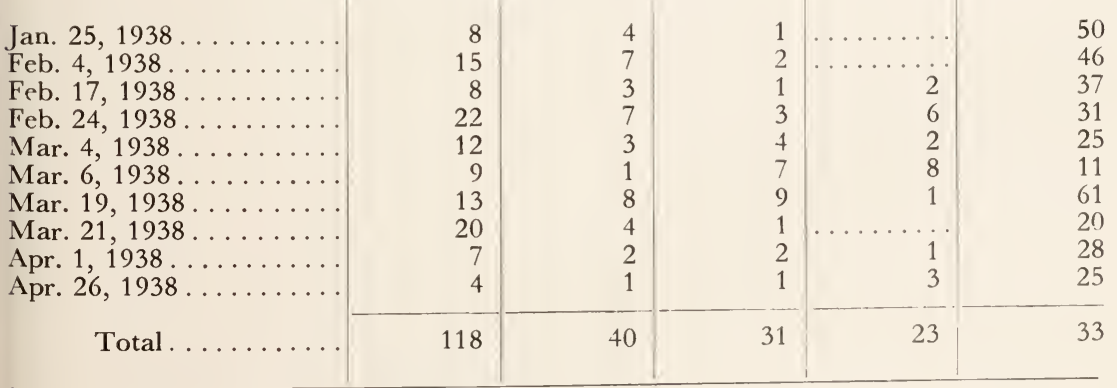




\section{Fauna of the National Parks of the United States}

Classified Counts Made in 1937-38 in Different Range Units ALONG YELLOWSTONE RIVER BETWEEN BLACKTAIL DEER CREEK AND LITTLE COTTONWOOD CREEK (POOR RANGE)

\begin{tabular}{|c|c|c|c|c|c|}
\hline & Doe & Fawn & Buck & $\begin{array}{c}\text { Un- } \\
\text { identified }\end{array}$ & $\begin{array}{l}\text { Fawn- } \\
\text { doe } \\
\text { ratio }\end{array}$ \\
\hline $\begin{array}{l}\text { Nov. } 23,1937 \ldots \ldots \ldots \ldots \\
\text { Jan. } 25,1938 \ldots \ldots \ldots \ldots \\
\text { Feb. } 4,1938 \ldots \ldots \ldots \ldots \\
\text { Feb. } 16,1938 \ldots \ldots \ldots \ldots \\
\text { Mar. } 5,1938 \ldots \ldots \ldots \ldots \\
\text { Mar. } 20,1938 \ldots \ldots \ldots \ldots \ldots \\
\text { Apr. } 1,1938 \ldots \ldots \ldots \ldots \ldots \\
\text { Apr. } 26,1938 \ldots \ldots \ldots \ldots \ldots\end{array}$ & $\begin{array}{r}3 \\
6 \\
16 \\
72 \\
88 \\
22 \\
31 \\
63\end{array}$ & $\begin{array}{r}3 \\
5 \\
3 \\
11 \\
13 \\
6 \\
3 \\
2\end{array}$ & 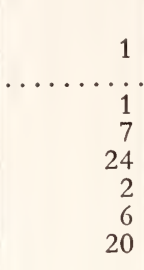 & $\begin{array}{l}\ldots \ldots \\
\ldots \ldots \ldots \\
\ldots \ldots\end{array}$ & $\begin{array}{r}\text { Percent } \\
100 \\
83 \\
18 \\
15 \\
14 \\
27 \\
9 \\
3\end{array}$ \\
\hline Total ........... & 301 & 46 & 61 & 41 & 15 \\
\hline
\end{tabular}

ALONG LOWER BLACKTAIL DEER CREEK (POOR RANGE)

Feb. $5,1938 \ldots \ldots \ldots \ldots . \ldots \ldots \ldots$

ALONG TOP OF RATTLESNAKE BUTTE BETWEEN TURKEY PEN AND BLACKTAIL DEER CREEK (POOR RANGE)

\begin{tabular}{|c|c|c|c|c|c|}
\hline $\begin{array}{l}\text { Feb. 24, } 1938 \ldots \ldots \ldots \ldots \\
\text { Mar. 1, } 1938 \ldots \ldots \ldots \ldots \ldots \\
\text { Mar. 21, } 1938 \ldots \ldots \ldots \ldots\end{array}$ & $\begin{array}{r}2 \\
\ldots \ldots \\
3\end{array}$ & ..... & $\begin{array}{rr}11 \\
& \\
& \end{array}$ & 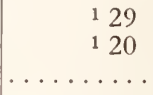 & $\begin{array}{r}\quad 133 \\
\ldots \ldots \\
\quad \ldots 6\end{array}$ \\
\hline Total .......... & 5 & 5 & 19 & 49 & 100 \\
\hline
\end{tabular}

ALONG YELLOWSTONE RIVER BETWEEN HELLROARING CREEK AND JUNCTION BUTTE

\begin{tabular}{|c|c|c|c|c|c|}
\hline $\begin{array}{l}\text { Nov. } 23,1937 \ldots \ldots \ldots \ldots \\
\text { Apr. } 2,1938 \ldots \ldots \ldots \ldots\end{array}$ & $\begin{array}{l}2 \\
9\end{array}$ & $\begin{array}{l}2 \\
1\end{array}$ & $\begin{array}{l}1 \\
7\end{array}$ & 3 & $\begin{array}{r}100 \\
11\end{array}$ \\
\hline Total .......... & 11 & 3 & 8 & 3 & 27 \\
\hline
\end{tabular}

\begin{tabular}{|c|c|c|c|c|c|}
\hline \multicolumn{6}{|c|}{ TOWER FALLS } \\
\hline Apr. $25,1938 \ldots \ldots \ldots$ & 6 & 3 & 1 & & 50 \\
\hline
\end{tabular}

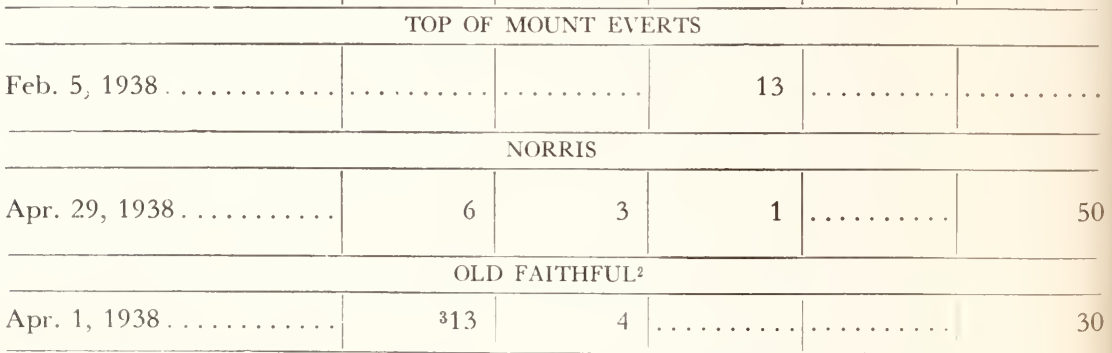

\footnotetext{
1 Probably bucks.

2 Figures supplied by Ranger Evans. ${ }^{3}$ Adults.
} 


\section{Ecology of the Coyote in the Yellowstone}

\section{Best late counts excerpted from classified counts}

\begin{tabular}{|c|c|c|c|c|c|c|}
\hline Locality & 1938 & Doe & Fawn & Buck & $\begin{array}{l}\text { Uniden- } \\
\text { tified }\end{array}$ & $\begin{array}{c}\text { Fawn- } \\
\text { doe } \\
\text { ratio }\end{array}$ \\
\hline 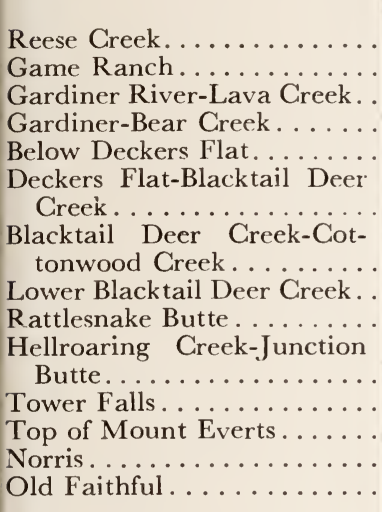 & $\begin{array}{lr}\text { Apr. } & 20 \\
\text { Apr. } 28 \\
\text { Apr. } 21 \\
\text { Feb. } 15 \\
\text { Apr. } 1 \\
\text { Mar. } 21 \\
\text { Apr. } 26 \\
\text { Feb. } 5 \\
\text { Feb. } 24 \\
\text { Apr. } 2 \\
\text { Apr. } 25 \\
\text { Feb. } 5 \\
\text { Apr. } 29 \\
\text { Apr. }\end{array}$ & $\begin{array}{r}77 \\
87 \\
154 \\
16 \\
23 \\
\\
20 \\
\\
63 \\
9 \\
2 \\
\\
9 \\
6 \\
\ldots \\
6 \\
13\end{array}$ & $\begin{array}{r}33 \\
36 \\
59 \\
9 \\
14 \\
\\
4 \\
\\
2 \\
3 \\
3 \\
1 \\
3 \\
\cdots \\
3 \\
4\end{array}$ & 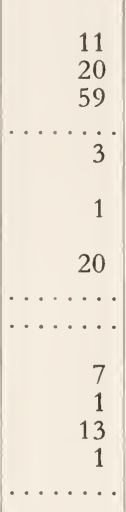 & 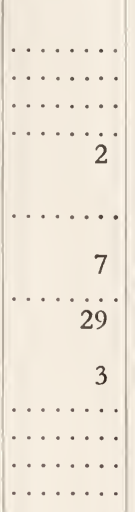 & $\begin{array}{r}\text { Percent } \\
42 \\
41 \\
38 \\
56 \\
60 \\
\\
20 \\
\\
3 \\
33 \\
133\end{array}$ \\
\hline Total ........... & & 485 & 174 & 136 & 41 & 35 \\
\hline
\end{tabular}

\section{Adults.}

\section{LOSS OF FAWNS}

Losses during winter of 1937-38. - The latest large counts for the different range units have been placed in one table for convenience. See page 72 . Most of these counts were made in April, many late in that month. Limited fawn losses probably occurred after some of these counts were made, but on the whole the figures for the fawns are close to the proportion that came through the winter. Since these counts probably represent about 75 percent of the population, the numbers of fawns and does in the counts are not far from the actual numbers on the ranges.

The total of the late counts made over the main range units is 485 does, 174 fawns, 136 bucks, and 41 deer unidentified. The fawn-doe ratio in these counts is 35 percent. The percentage increase over the doe and buck populations combined is 28 percent. It is known that relatively fewer bucks than does are counted, so to be really conservative the number of bucks might be doubled. Then the increase in the herd due to the fawn crop becomes about 22 percent. This includes the population along the Yellowstone River where scarcely any fawns survived, so it appears that there was a healthy increase in the deer population as a whole, even though the winter over part of the range was more severe than usual. 


\section{Fauna of the National Parks of the Lnited States}

Since large counts of deer were not secured when they first came to the winter range and therefore some mortality had already occurred when the first extensive counts were made in January, figures are not available which would give a good clue to the actual loss of fawns during the winter. Counts made in January (one) and in February total 355 does and 176 fawns for Reese Creek, the Game Ranch, along Gardiner River and Lava Creek, below Deckers Flat, between Deckers Flat and Blacktail Deer Creek, and between Blacktail Deer Creek and Little Cottonwood Creek. Counts made in March (one) and in April on the same ranges total 424 does and 148 fawns. If the early fawn ratio was true for the whole population, then the April count shows a loss of 62 fawns or 29 percent of the fawns since February. There was, of course, considerable loss previous to the February counts, especially on the Yellowstone River range. Therefore the actual winter loss of fawns was much higher than 29 percent, being almost 100 percent along the Yellowstone River.

Fawn mortality higher than doe mortality. - In practically all of the areas there was a downward trend in the ratio of fawns to does. Where the mortality was not so heavy this differential mortality was not great, but along the Yellowstone River, where the mortality was drastic, the ratio dropped almost to zero.

Fawn-Doe Ratio, Winter of 1937-38

\begin{tabular}{|c|c|c|c|c|}
\hline \multirow{2}{*}{ Locality } & \multicolumn{2}{|c|}{ Early count } & \multicolumn{2}{|c|}{ Late count } \\
\hline & Date & Ratio & Date & Ratio \\
\hline 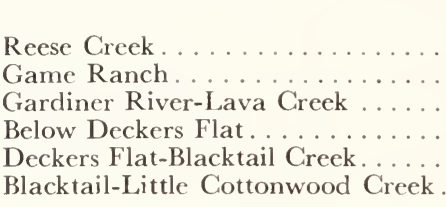 & $\begin{array}{lr}\text { Feb. } & 20 \\
\text { Feb. } & 21 \\
\text { Feb. } & 22 \\
\text { Jan. } & 25 \\
\text { Feb. } & 4 \\
\text { Jan. } & 25\end{array}$ & $\begin{array}{r}\text { Percent } \\
60 \\
56 \\
53 \\
78 \\
46 \\
83\end{array}$ & $\begin{array}{l}\text { Apr. } 20 \\
\text { Apr. } 28 \\
\text { Apr. } 21 \\
\text { Mar. } 21 \\
\text { Mar. } 21 \\
\text { Apr. } 26\end{array}$ & $\begin{array}{r}\text { Persent } \\
43 \\
41 \\
38 \\
37 \\
20 \\
3\end{array}$ \\
\hline
\end{tabular}

Fawn mortality correlated with winter range conditions.-- The Reese Creek, Game Ranch, and Gardiner River-Lava Creek winter ranges, and that below Deckers Flat, are not very different in quality, but the first named is the best of the three, being the least overbrowsed. The Game Ranch range I would rate as slightly superior to the Gardiner River-Lava Creek range because of the greater availability of Douglas fir browse, and the range below Deckers Flat is similar to the others in quality. The differences between these ranges are hardly large enough to expect a corre- 


\section{Ecology of the Coyote in the Yellowstone}

sponding difference in fawn survival, but the last deer counts on three of these ranges showed a correlation of range quality and fawn survival, the ratios being 42 percent for Reese Creek, 41 percent for the Game Ranch, and 38 percent for the Gardiner River-Lava Creek area. The range below Deckers Flat had a fawn-doe ratio of 60 percent but this was higher than usual because of a low count of does so that 47 percent is probably a much better figure. The differences in the fawn ratios are too small to be of any significance. What is significant is the similarity of fawn survival on these rather similar ranges.

The range along the Yellowstone River above Deckers Flat was a strikingly inferior and less favorable winter range than the previously mentioned four ranges, because of severe overbrowsing, scattered distribution of food plants, and especially crusted snow. On the section between Deckers Flat and Blacktail Deer Creek a rather small count made on March 21 showed a 20-percent fawn-doe ratio and as some mortality resulted after this date, survival on this range was undoubtedly very low.

On the section of this range between Blacktail Deer Creek and Little Cottonwood Creek 72 does and 11 fawns were counted on February 16, 88 does and 13 fawns on March 5, and 63 does and 2 fawns on April 26. The survival of fawns on this range was almost nil. Apparently a good fawn crop arrived on this range but heavy losses commenced in January. Between Hellroaring and Tower Falls, a range covered with crusted snow, the survival of fawns was also low. On April 2, I counted 9 does and 1 fawn, the latter appearing to be very weak. The correlation of the fawn survival and condition of the winter ranges was very pronounced in the winter of 1937-38.

Losses during winter of 1938-39.- In the fall of 1938 deer were observed between November 11 and November 23 but during this period only a few of the deer had returned to the winter range so the counts were not entirely representative. The following counts suggest that a fairly large proportion of fawns arrived on the winter range. The fawn-doe ratio of the total number recorded is 83 .

\begin{tabular}{|c|c|c|c|c|c|}
\hline Date & Location & Doe & Fawn & Buck & Total \\
\hline $\begin{array}{ll}\text { Nov. } & 12 \\
\text { Nov. } & 13 \\
\text { Nov. } & 15 \\
\text { Nov. } & 22\end{array}$ & $\begin{array}{l}\text { Game Ranch . . . . . . } \\
\text { Undine Falls . . . . . } \\
\text { Gardiner River . . } \\
\text { Terrace Hot Springs. }\end{array}$ & $\begin{array}{r}3 \\
2 \\
11 \\
21\end{array}$ & $\begin{array}{r}3 \\
4 \\
8 \\
16\end{array}$ & $\begin{array}{l}2 \\
2 \\
3 \\
8\end{array}$ & $\begin{array}{r}8 \\
8 \\
22 \\
45\end{array}$ \\
\hline & Total. & 37 & 31 & 15 & 83 \\
\hline
\end{tabular}




\section{Fauna of the National Parks of the United States}

In the spring of 1939 the following deer counts were made but the samples were too small to give the full picture:

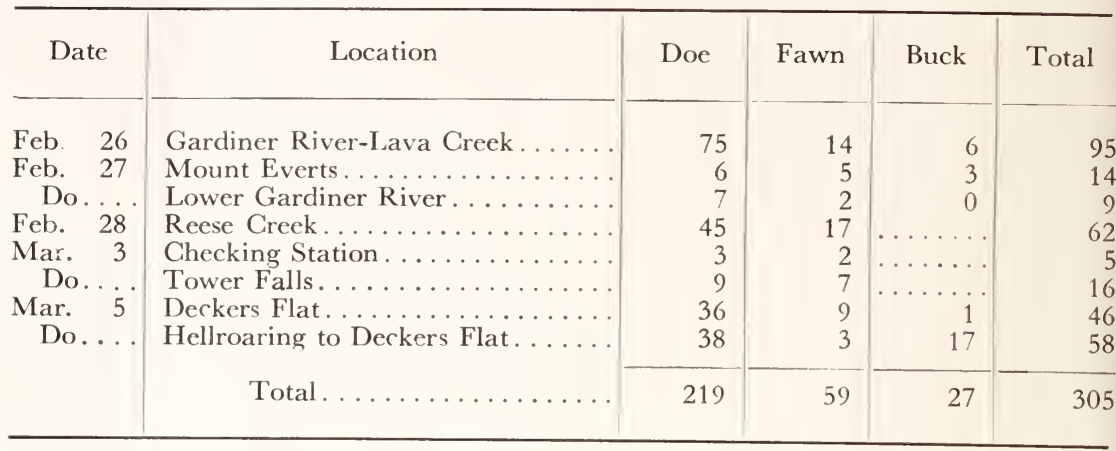

The fawn-doe ratio of all counts combined is 26, a lower ratio than existed during the winter of 1937-38. The figures are too incomplete to make detailed comparisons with those of the previous winter. Fawn survival apparently was extremely low in the winter of 1938-39 along the Yellowstone River from Hellroaring to Deckers Flat, just as it was in the winter of 1937-38. The fawn-doe ratios on the other ranges, except at Tower Falls, were lower in the winter of 1938-39 than in the previous year although more complete counts might have shown less difference. In 1938-39 there was more snow over parts of the deer ranges in the Reese Creek, Game Ranch, and Gardiner River sections. This additional snow, along with continued deterioration of the range, may have been a factor in the apparent lower fawn survival that winter over the above-named deer ranges, but more complete counts and closer observation would be necessary for certainty.

Along the Gardiner River on February 26, 1939, I noted two carcasses of deer, one cleaned and the other partly eaten by four coyotes. One carcass was that of an old buck, the other of an old doe with teeth worn to the gums. Ranger Grimm found remains of three adult bucks in the Reese Creek area which apparently had died from wounds received during the hunting season. No bucks were seen on Reese Creek near the edge of the park adjacent to the area where considerable hunting took place the previous fall. The apparent scarcity of bucks in this region may be due to this drain.

On March 5, 1939, hair remains of two deer were found near Blacktail Deer Creek and Crevice Creek and the mandible of a fawn below Crevice Creek. The general impression received in walking from Hellroaring 


\section{Ecology of the Coyote in the Yellowstone}

Creek to Gardiner along the Yellowstone River was that deer were as numerous as during the winter of 1937-38. They occupied a somewhat wider range, being found near Hellroaring cabin where they were not found in the winter of 1937-38. The fawn increase in 1939 is apparently sufficiently large to maintain or possibly increase the deer population in the park.

Fawns killed by coyotes on the winter range.- Although healthy adult deer do not seem to be subject to coyote predation, it appears that fawns are occasionally killed by coyotes on the winter range. Tracks in the snow near fawn remains indicated in several instances that the fawns had been killed by coyotes. Since our knowledge of the circumstances under which prey is killed by predators is scant, it seems desirable to give the evidence found at carcasses which showed indications that coyotes had made the kill.

1938

January $26 \ldots$... At Crevice Lake some ravens were seen circling over a spot high up on a steep slope. As I neared the spot two coyotes ran off, one of them carrying a piece of hide. The stomach, a lower mandible, hair, and a few pieces of hide were all that remained of a fawn carcass. On some ledges just above the beginning of a 300-yard trail made by the sliding carcass were four deer beds. Tracks showed that the fawn had made two jumps from its bed down the precipitous slope, and had fallen on the third jump and started its slide from which it never rose. Above the deer beds were a few coyote tracks. It seemed probable that coyotes had startled the deer and that the fawn had been attacked by coyotes after it had slid down the steep slope. This fawn may have fallen because it was weak, and possibly it was unable to rise after sliding down even before the coyotes finished it.

A short distance below Crevice Lake along the trail I found the remains of a fawn that had been killed recently. Two leg bones, a shoulder blade, an innominate bone, a few pieces of skin, and the stomach contents were all that were left; the flesh had been completely eaten. Just above the remains were fresh tracks of four deer which had been jumping down the hillside. It seemed probable that the dead fawn had been one of the jumping deer.

January $28 \ldots$.... Along the Yellowstone River about a half mile below the mouth of Lamar Creek, a little after noon, my attention was attracted by some ravens flying in small circles over scattered Douglas firs. As some of the ravens were alighting, it was apparent that they were at a carcass. Coming over the last ridge, I saw five coyotes run away from the carcass in different directions. They had been feeding on a male fawn deer, having eaten most of the hind quarters, the meat off the mandibles, and the ribs on one side. The fawn had been killed but a few hours previously for it was not frozen and still steamed a little. The tracks on the slope above the carcass showed that before the fawn had fallen it 


\section{Fauna of the National Parks of the United States}

had been jumping in a zigzag course. For a distance of 100 yards on the back trail of the deer, a little blood appeared in places. Apparently the coyotes had been chasing the deer but there were so many tracks in the snow that I could not determine how the coyotes had maneuvered. The fawn had been running down hill before falling. About 400 yards from the dead fawn there were four adult deer feeding unconcernedly on the open slope.

January $29 . \ldots$ At the mouth of Cottonwood Creek I saw where three or four deer had been jumping down a steep slope. Parallel to the deer tracks were coyote tracks, so it seemed that coyotes had been chasing the deer. One of the latter, a fawn, had fallen and had been dragged down the slope several yards and eaten. Little remained but some hair and the entrails.

About one-fourth of a mile below the mouth of Cottonwood Creek were hair and stomach remains of another fawn. Coming off the hillside immediately above the fawn were tracks of four jumping deer. Possibly the deer had been chased and the fawn had fallen.

February 13... Below Undine Falls along the Creek I found hair and stomach remains of a fawn that had died the day before. The snow had been tracked up by the coyotes and short trails led off to spots where the animals had brought pieces of the carcass to eat. The tracks indicated that the deer had been chased by four or five coyotes. On an open flat 30 yards above the remains were some bunches of deer hair and the area was tracked up as though the deer had been brought to bay. The drifting snow had covered the tracks too much to be sure of what had taken place. From this spot the deer had jumped toward the creek and descended an almost perpcndicular bank, more than 20 feet high, which was one side of a short narrow draw. The deer had fallen at the base of the bank, and here it had been devoured.

February 15.... Along the Yellowstonc River below the mouth of Crevice Creek in a shallow ravine I found the carcass of a female fawn that had probably been dead only a few hours. The carcass was still limp although the temperature was about $20^{\circ}$ below zero. Most of one side, including front and hind quarters, part of the intestines, and the heart and liver had been eaten. The coyotes apparently had eaten their fill, for on the fresh snow could be seen where they had been rolling and cleaning their muzzles and throats. There was not a trace of fat on the carcass, not even around the intestines. The animal had not been ham strung. There was a deep bite near the base of the neck, which had chipped part of a dorsal process of a vertebra. The tracks indicated that three coyotes had chased the fawn down a stecp slope of jumbled boulders covered with a light fall of loose snow. One track followed that of the fawn, the other two were 6 or 7 yards to one side. I was able to backtrack the chase only about 60 yards to an area where elk and deer tracks were too numerous to permit further tracking. The fawn had been making 10- and 11-foot jumps. On a large boulder with a drop of 10 feet below it, the fawn had fallen as it struck, judging from the marks in the snow and the hair hanging on the gooseberry branches spreading 


\section{Ecology of the Coyote in the Yellowestone}

over the rock. Below the rock the fawn had made five more jumps before falling. From here the carcass had been dragged over the rocks a dozen yards to the place where I found it. Lack of any fat on the animal suggests a weak fawn. On March 4 the carcass was still untouched by coyotes, probably because I had handled it considerably, but it was eaten later.

February $18 \ldots$ On a slope of Mount Everts a little below Undine Falls late in the afternoon I saw two ravens circling over a draw and then lighting on a tree in the area over which they had circled. Their actions indicated that a carcass lay in the draw so I followed a ridge leading to it. In the ravine to one side of me I caught a glimpse of two coyotes also traveling toward the spot pointed out by the ravens. Later these two coyotes got my scent and ran up a ridge above the carcass where they joined two others, one of which seemed to be leaving. One of the coyotes picked up the leg of a deer lying on the ridge but dropped it when another approached with arched back, lowered head, and wide open snarling mouth. A third coyote then picked up the leg and started up the ridge unmolested. Either the second coyote was interceding for the third one, or else the lordship of the third one was recognized by the others. In the ravine I found a fawn partially eaten. The carcass had slid from near the top of Mount Everts, several hundred yards down a precipitous draw filled with hard packed drifted snow. In one place where the carcass had struck some cedars bordering the draw, branches 1 inch in diameter had been broken by the impact. There were too many tracks to decipher what had taken place but it is probable that the fawn had been chased toward the draw, lost its footing, and then taken the long slide. It undoubtedly was unable to rise when it stopped sliding because of the injuries it must have received en route. There were coyote tracks above the steep gully and all the way down to the carcass. Two nosefly larvae were found in the nasal passages. Since the gular pouch and adjacent parts had been exposed, possibly most of the larvae had been eaten by magpies. The fawn was in poor condition for there was not a trace of fat, not even on the mesenteries. The stomach contents consisted of about 99 percent Douglas fir needles and twigs.

February $20 \ldots$ The following incident brings out several points so I will tell it in full even though there is some doubt that a coyote did the killing. About 10 p. m. a resident of Gardiner knocked at my door. I opened it, and was confronted by a tragic face and a breast bursting with righteous indignation. He asked if I was the man studying the coyote. "Well," he said, "I just wanted to tell you that a deer, still warm, is on the Mammoth Road near the upper bridge, which the coyotes have killed. If the coyotes act that way, I don't think much of them."

I thanked him for the information without offering any comments on the morals or amorals of the coyote and told him how happy I was to know about the deer for I wanted all possible information on coyote predation, and that I would investigate. I drove toward Mammoth and found the fresh carcass along the road and saw a coyote cross the 


\section{Fauna of the National Parks of the United States}

road near it. The carcass was half eaten and the heart, lungs, and liver were missing, but the head was intact. I examined the carcass in my cabin. There was no fat on the animal. In the gular pouch, frontal sinuses, and nasal passages I found 104 botfly larvae, most of which were about 1 inch long. The nasal passages were packed with the larvae so that it was difficult to see how the animal managed to breathe. If the coyotes had killed this deer, they had eliminated an animal which unquestionably was unfit. There is a possibility that the fawn had been hit by a car, although I saw nothing that looked like bruises on the parts of the carcass available for examination. In any event this deer was in such poor condition that it would have been easy prey for the coyotes. I saved the larvae which filled a small olive jar and showed them to my informant, who had not realized that animals in Nature could be so afflicted.

\section{COYOTE METHOD OF HUNTING FAWNS}

I did not have the good fortune to observe the coyotes in the act of hunting a fawn but have heard many persons state that coyotes systematically chase deer down the slopes and catch them at the bottom. Along the Yellowstone River it has been said that deer have been driven down to the river where other coyotes were waiting to help finish them.

On March 19, along the Yellowstone River below Crevice Creek I had an experience with some deer which may be significant in explaining coyote predation on fawns. Fresh deer tracks in the snow crossed the trail and I followed them up the slope on the chance of seeing the deer and getting a count of the fawns. I had gone but 200 yards or so when I came upon 14 deer, 5 of which I classified as fawns. My observation was hasty for the deer ran off on seeing me, and since the fawn proportion was unusually high, I followed in order to check my count. I again saw the deer crossing a steep open rocky slope but several passed out of sight into a draw before I could get a full count. I noted two fawns that appeared tired, lagging 25 or 30 yards behind the others. At the edge of the draw I found the band of deer only 30 or 40 yards away. They hurried quickly up the steep slope, all except the two fawns behind. One of these kept on, but the other stalled. I hurried upward toward it. After a brief rest it was able to climb a little farther but again stopped, trying to climb but too weak to do so. Another brief rest and it walked forward a few yards more and lay down in a hiding posture with head and neck stretched forward and held close to the ground. I continued to hurry up the steep slope in order not to give the fawn too much time to recuperate. When I was within a few feet it rose, and, finding climbing too difficult, followed a contour of the slope instead. I tried to keep directly below it to force it upward, thinking that if it started down the slope it 


\section{Ecology of the Coyote in the Yellowestone}

might be able to run away from me. However, it got ahead in spite of my efforts and swung around down the slope. When it had made four or five creditable jumps I thought it was going to run away. But its legs buckled on the last jump and it went down in a heap, rolling over several times before coming to a stop. It gained its feet before I caught up with it, but after a few more jumps it fell again, rolling and sliding several yards to a stop. It lay perfectly relaxed with its head in a crack between two rocks. I photographed it, and while I was changing film it managed to take two or three more jumps before falling and rolling again. Now it lay utterly exhausted, not even twitching a muscle when handled.

An autopsy revealed clear lungs and liver, and an absence of nosefly larvae. There were a moderate number of ticks, especially on the neck. The animal, a female, was very thin. It was drooling a little but this may have been due to overexertion.

I wondered if I had staged a hunt similar in many details to a coyote hunt. Possibly the coyote harasses a band of deer on the chance of finding a weak animal. The herd moves up the hill and the weak fawns are left behind. Lacking strength to run up hill the fawn runs down the slope. This may explain why most chases are downhill. His weakness causes him to stumble or slip in the rough steep terrain since considerable strength is necessary to brace himself in landing at the end of each downhill jump. The fawn when killed by coyotes may at times be lying utterly exhausted. This is speculative, of course, but seems permissible because of the similarity between my observation of tracks of fawns presumably killed by coyotes and my own "hunt." That there are many weak and ailing fawns during the winter is unquestionable.

These data have been given elsewhere, but I might mention here that on the day the above observation was made, besides the second weak fawn in the band I was following, one was seen across the Yellowstone River so weak that it was tottering and stumbling. On March 5 another very thin fawn was seen alone, probably left behind when the band moved on, and on April 1 a lone weak fawn was seen.

On February 12, 1938, I witnessed an incident in which the coyotes seemed to be watching a deer herd, possibly seeking an animal that they could run down. All day the air was full of snow and a strong wind was drifting the snow along in swirls, so that tracking was almost impossible and visibility was poor. A half mile above the mouth of Lava Creek I saw, about 1 p. m., a band of deer that had sought the shelter of a grove of firs some distance up the slope of Mount Everts. Three or four hundred yards farther along two coyotes crossed the trail ahead of me and ran up the slope 


\section{Fauna of the National Parks of the United States}

in the general direction of the deer. About a quarter mile further along I met three more coyotes coming out of the creek bottom. They also climbed the slope of Mount Everts, stopping occasionally to watch me.

About 2 hours later when returning I happened to look behind and saw a deer bounding down the slope of Mount Everts to the creek bottom and up on the other slope. The deer appeared to be a yearling doe. I waited a few minutes to see if she was being chased, and then after following her trail for a time back-tracked her up the slope of Everts. The drifting snow made it difficult to keep on the trail but I managed to follow the widely spaced tracks to one of the scattered clumps of trees high up the slope. Tracks of a running coyote following the deer were seen near the grove of trees, but beyond this shelter all tracks were blown away. A little beyond this point in a thick grove of trees, near which I had seen the band of deer from the creek bottom earlier in the afternoon, I came upon 11 deer, four of which were fawns and one a buck. The deer were standing in the shelter of the trees apparently avoiding the strong wind sweeping over the slope. As I approached a few steps nearer the band, I saw four coyotes run off. One of them had been sitting by a clump of cedar about 20 yards from the deer, and the other coyotes had been sitting a few yards lower down. The deer when first sighted seemed unconcerned, and when I approached they moved up the slope only a short distance. It seemed that the deer I had seen crossing the creek bottom had come from this band and had been chased a short distance by at least one of the coyotes. The observations suggest that the coyotes follow the bands of deer at times and thus have a chance to pick up weak animals. I do not know how readily the coyotes would attack a healthy fawn, but it would seem that they would not have a chance to do so if the fawn kept its head and refused to run away from

the band. It is possible that through the evolutionary history of the deer, fawns that left the bands were eliminated, thus constantly reducing that tendency. Apparently coyotes are clever in detecting debility in an animal. As winter progresses and weak animals begin to appear, the coyotes seem to quickly form the habit of scrutinizing bands of deer for any such possibilities.

\section{COYOTE PREDATION CORRELATED WITH RANGE CONDITIONS}

The evidence is not conclusive, but observations on the general interrelationships between the range, deer, and the coyote suggest that there is a definite correlation between condition of the range and coyote predation on deer. 


\section{Ecology of the Coyote in the Yellowstone}

In the winter of 1936--37, when snow conditions were favorable to the deer, predation was light. The deer were in good condition and apparently were little molested by coyotes. In that winter some coyotes were weak, others died, appearing, at least superficially, to have starved in the midst of a heavy fawn population. Some predation apparently took place in the poorest part of the Yellowstone River range, but here also available data indicate that most of the fawns survived. The conditions existing in 1936-37 would indicate that deer in good condition were not subject to heavy coyote predation.

In contrast with the favorable conditions of the winter of 1936-37, those of 1937-38 were unusually severe due to crusted snow on the winter range along the Yellowstone River, combined with the scattered distribution of the food plants. Coyote kills appeared to be much more numerous in the winter of 1937-38 than in the previous winter, showing further correlation of predation with condition of range. Furthermore, during the winter of 1937-38, predation on the poorer ranges appeared to be much heavier than on the better areas. Six of the eight kills attributed to coyotes were found along the Yellowstone River and relatively more carcasses were found on this poor range than on the better ranges. However, it is not known what proportion of these carcasses were the result of coyote predation so that number of carcasses found is not necessarily an index of predation on a given range.

In the winter of 1937-38, when the fawns were in extremely poor condition, it seems likely that about the same number of fawns would have died on the ranges in the absence of coyote predation. The coyotes were probably preying upon fawns which, for the most part, were doomed to die from malnutrition or disease sooner or later during the winter. As pointed out elsewhere, several fawns were seen in an extremely weak condition, two of which were off by themselves, and others were known to have died from starvation or disease. The ease with which I ran down a weak fawn suggests coyotes have no difficulty in securing a fawn in such condition and that very likely bands are followed by coyotes in order to pick up such weaklings. If all the fawns in a band happen to be strong the coyotes probably seek food elsewhere. If deer in good condition were not able to ward off coyote attack, the relatively high survival of fawns often found in the midst of large population of coyotes would not exist, and the deer would long ago have been exterminated.

Coyote predation on deer increases as the winter season advances. The "big kill" is spoken of as coming in February and March. This might of course be due to snow conditions being adverse to the safety of the deer, 


\section{Fauna of the National Parks of the United States}

but nevertheless the heavier predation coincides with the period of heavy mortality due to disease and malnutrition. The occurrence of greatest predation at a time when the animals are generally in a weakened condition also strongly suggests that the coyotes for the most part are getting the doomed fawns.

\section{DEER-COYOTE BEHAVIOR}

Behavior of adult deer when in proximity to coyotes shows that they are not afraid, but on the contrary are prone to assume the offensive. There was no indication that healthy adult deer were killed. Bucks generally pay little attention to coyotes, but does usually are more attentive and seem somewhat concerned, and their behavior suggests that they recognize the coyote as a potential enemy to their fawns.

Acting Supt. H. C. Benson in his annual report for 1909 states: "Quite a number of coyotes were killed last year-about 60 in all-but still they seem to increase. It is doubtful, however, if they kill much game, as the deer seem to be able to protect themselves. On several occasions last winter, I saw deer chasing coyotes instead of being chased by them."

Ranger Condon, who spent the winter of 1936-37 at Tower Falls, said that all winter the coyotes had great respect for the deer. When coyotes happened to come near, the hair on the deer's backs was raised, and the coyotes quickly moved off. The loose snow prevailing all winter was only a slight impediment to deer, but made travel difficult for coyotes. Consequently the former fared well, and had little regard for the coyotes as a source of danger. During the winter of 1938-39. Condon secured some exceptionally fine motion pictures of five or six does and fawns chasing a coyote.

Assistant Park Naturalist F. Oberhansley told me that he had seen a doe chase a coyote in January 1938 and that Ranger Elliot had also observed a similar incident.

On January 15, 1938, a coyote was observed passing within 40 yards of a group of does and fawns without disturbing them. The deer cocked their ears but at once resumed feeding.

On February 6, 1938, I observed three coyotes and six deer (including two fawns) feeding in close proximity at the Mammoth dump without taking much notice of one another. The deer fed at the choicest part of the dump.

Early in the morning of February 9, 1938, I caught a glimpse of a coyote passing through some willows along the Gardiner River, and, as I watched, caught glimpses of other coyotes traveling parallel to the first one a few 


\section{Ecology of the Coyote in the Yellowstone}

yards to one side. Five coyotes were moving up the river in loose array, one or another stopping momentarily to sniff at something, and then moving forward with the rest. They probably had been feeding at an elk carcass. Upstream, ahead of the coyotes, a doe and fawn were feeding on a low rise above the river bottom. The doe caught sight of the coyotes coming up the river while they were still some distance away. After a few moments of sharp attention, she walked slowly and stiffly down the slope, with ears cocked and head held high. I did not see the coyotes as they came abreast of the doe, but as she came out on the bottom I saw her dash after one of the coyotes, chasing it in a small circle about a dozen yards across. The coyote, with its best efforts, barely managed to avoid the striking hoofs which were reaching out for it. After dodging away, it joined the others which had moved past. The doe returned slowly toward the fawn who had remained watching from the slope 40 yards away.

On February 18, 1938, on the slope of Mount Everts, a coyote was howling about 50 yards away from three bucks, who paid no attention. A doe with a fawn about 150 yards away cocked her ears in the direction of the coyote and took a dozen slow deliberate steps toward it. After watching it a moment she fled over a ridge out of sight.

On March 22, 1938, a band of deer, including some fawns, was feeding complacently about 100 yards from where two coyotes were sitting on their haunches.

Late in the afternoon of March 22, 1938, four coyotes were seen trotting past three does and two fawns feeding among some willows along the Gardiner River. The coyotes had been eating from two elk carcasses about 30 yards from where the deer were browsing. The deer took no notice of the coyotes; they probably had become accustomed to the latter feeding near them. On April 2, it was reported that several Civilian Conservation Corps enrollees had seen deer chasing coyotes in this area and it was thought by my informant that the deer were probably being attacked. However, since coyotes were feeding on an elk carcass in the area, it is more likely that the deer chased coyotes that were en route to the carrion.

On March 25, 1938, along the Gardiner River three does and a fawn, as they neared the crest of a hill, met four coyotes, who veered to one side to pass. The coyotes, after getting by, paused and sniffed about. The three does advanced toward them in a fanlike formation with slow and deliberate steps. As one of the does approached a coyote, the latter generally moved off to a safe distance, but two or three times a doe approached so near that by making a sudden dash it forced the coyote to scurry and dodge to escape. After a brief period the coyotes moved off. The fawn in the meantime stood 


\section{Fauna of the National Parks of the United States}

watching from a spot behind the does. Later these coyotes slept on the snow about 150 yards from 11 does and 5 fawns, which were resting in the sun, many with closed eyes.

Ranger John Jay told me that an acquaintance who worked for the hotel company saw three deer around a pile of rocks to which a coyote had retreated. Each time the coyote tried to leave the rock pile the deer chased it back. The deer and the coyote were still at the rock pile an hour later.

Observations indicate, then, that at times deer chase coyotes and at other times coyotes chase deer and prey on certain individuals when they are at a disadvantage. The coyote is by no means able to kill deer at will. An observation by E. J. Sawyer (Yellowstone Nature Notes, August 1924, p. 2) seems pertinent here:

A number of times during the past few weeks I have seen a weasel at grips and near grips with a Kennecott's ground squirrel. The cireumstances vary in a rather puzzling way. Sometimes the weasel is in hot pursuit of the squirrel, the latter fleeing as if, indeed, for his life. Again, I have seen a large ground squirrel ehasing a weasel and actually attacking him savagely; still again, a weasel and ground squirrel of average size in a eatchas-catch-can wrestling match, honors even, the participants finally going off in opposite directions, apparently none the worse for their encounter. A weasel living for weeks about the Buffalo Corral station seemed to be continually hunting ground squirrels when not himself pursued by them. The ground squirrels are especially abundant at this place. I have never seen either animal kill the other, though the ranger stationed there tells me he has seen the weasel kill the squirrels and take them into a hole. What is the explanation? Apparently the weasel preys on young ground squirrels, also on older ones when he ean eateh them off their guard, but he finds many an intended victim a match and even an over-mateh for him."

It would seem that carnivores will habitually attack only species with which they can cope successfully. But certain prey species are on the borderline, placing the carnivore and prey in a delicate balance of power that may easily be disturbed. Judging by the situation in Yellowstone the mule deer falls in this category. This species can readily cope with the coyote under normal circumstances and falls victim only when its power of defense is diminished by crippling injuries, old age, malnutrition, disease, or perhaps situations such as extreme snow conditions. There is latitude in the operation of ecological interactions, so that there may be exceptional cases.

\section{STATUS OF DEER}

Official counts of deer in Yellowstone made by the rangers show a steady increase since 1934. (Coyote control was terminated in the spring of 1935.) The counts by years are as follows: 1934, 363; 1935, 610; 1936, 673; 1937, 843; and 1938, 850. 


\section{Ecology of the Coyote in the Yellowestone}

Estimates made during these years vary from 850 in 1934 to 900 in 1938. The numbers of deer during these years probably has not varied greatly. However, there may have been some decline after the winter of 1934-35 when a number of deer died around the Game Ranch and near Gardiner outside the park. A heavy loss was probable that spring over most of the winter range. In reviewing the report on the 1938 census I note that the recorded population is a little low in a few localities, doubtless because of unfavorable counting conditions on the particular days when the census was taken. For instance, only 13 deer were counted in the Cottonwood area. About a week before the official count I found 90 deer on the area; and 10 days after the official count at a time when bare slopes had brought the deer out in the open to feed, I found 143. The official count along the Yellowstone River below Blacktail Deer Creek is also low. In these two areas the actual count, if made under more favorable conditions, would probably be 200 higher than the number recorded. The estimated population in this wooded area where counting is difficult would of course be a still higher figure. The actual count of deer in the park in 1938 should, therefore, be in excess of 1,000 .

It seems probable that for some years the deer population has been held in check by range conditions and that the cause of mortality has been chiefly malnutrition and certain diseases, with other diseases and predation as secondary causes.

The primary winter deer foods now present in Yellowstone National Park are Douglas fir, sagebrush (Artemisia tridentata), yellowbrush, and to a lesser extent, in some localities, red cedar. Some food species such as poplar, service berry and willow, now scarce, probably once formed an important part of the diet. Other foods of less importance, because of their scarcity or lower palatability, are fringed sagebrush, greasewood (Atriplex oblanceolata), willow poplar, and Russian thistle. Over most of the range sagebrush is perhaps the most important winter food, at least on the basis of abundance and general use. Sagebrush was found in 24 of 39 stomachs examined during the winter. In 13 of these, sagebrush made up more than 50 percent of the contents, and in 3 more than 90 percent. Deer feed regularly on sagebrush, beginning in November (on the eighteenth 11 deer were seen feeding steadily on it) and continue well into the spring long after a variety of other green foods become available. Sage is heavily overbrowsed in places, especially on parts of the range near the Game Ranch and on the slopes of both sides of the Gardiner River. On some of these deer ranges, antelope have contributed to the overbrowsed condition of the sagebrush. Along the Yellowstone River the occurrence of sagebrush

$193095^{\circ}-40-7$ 


\section{Fauna of the National Parks of the United States}

is spotted, and near Deckers Flat it is much overbrowsed. The best sagebrush range is on Reese Creek, the lower part of which has until recently been hunted so extensively that there has not been a heavy concentration of deer for more than a short time.

Douglas fir, an important deer food, now affords very little browse. Deer were often seen reaching high for the twigs, and even standing with the forefeet on rocks to better reach the browse. A fawn stomach contained 100 percent Douglas fir and numerous other stomachs contained lesser amounts, but many analyses showed no fir since it was not readily available to most of the deer. Deer and elk both are responsible for overbrowsing the fir, but since elk are present in greater numbers, overbrowsing is largely due to them. Scarcity of Douglas fir is one of the worst defects of the deer range.

Yellowbrush is generally distributed over the winter range and is much eaten by deer, but does not rank as high in the deer diet as sagebrush and Douglas fir. Red cedar (Juniperus scopulorum) is important along the Yellowstone River because of the local scarcity of Douglas fir browse. In the fall and spring, when the deer are still consuming winter forage, on the winter range, green grass is eaten in large amounts. From its first appearance in spring it is closely cropped, and makes up an important supplement to the regular winter food supply Dry grass was eaten sparingly on a few occasions. It is very unpalatable to the population as a whole.

To summarize, the data indicate that the status of the deer is dependent upon the condition of the range, particularly the condition of sagebrush, Douglas fir, and, to a considerably less degree, of red cedar and yellowbrush. The condition of the deer range is dependent upon the number of deer and elk. If there were fewer elk there would probably be more deer. It seems certain that for several years the deer have been pressing the range, the population being as large as the condition of the range and competition of the elk permits. Some years rather heavy mortality of deer has been reported while in other years the mortality has been light, depending, no doubt, on winter conditions and deer concentrations. Some fawns are killed by coyotes in winter, but it appears that this predation largely affects the weak animals, many of which would die before summer. Judging from the rather high number of fawns that come to the winter range, apparently few are lost during fawning time. 


\section{Chapter VII}

\section{ANTELOPE IN RELATION TO COYOTES}

Demains of adult antelope (Antilocapra americana americana) were found R in 21 coyote droppings, and remains of fawns in 32. A total of 1,657 droppings were gathered on the antelope range. Considerable concern has been expressed over the welfare of the antelope, it being strongly felt by many that the coyote was a threat to its existence in Yellowstone. For this reason, factors affecting the antelope were carefully studied. Not only was the coyote pressure on antelope and the survival of fawns noted, but also such other factors as condition of the antelope winter range and competition from other game animals.

\section{WINTER RANGE}

The winter range of the antelope in the park consists of the sagebrush areas from Reese Creek to and including the lower slopes of Mount Everts and to Rattlesnake Butte on whose steep slopes some antelope are usually found all winter. In 1930 Ranger J. L. Greer in his November report stated that 93 antelope were seen on the bench lands outside the park north of the Yellowstone River in the vicinity of Bear Creek. The following month Ranger Allyn Hanks reported seeing 64 antelope in this area. It was unusual for this species to be found here even though the range is better than within the park. During the winter of 1937-38 a few antelope were occasionally found outside the park below Reese Creek. In the cold months of 1938-39 the majority of the antelope herd moved outside the park below Reese Creek, where there is good winter range. It is possible that the rather close confinement of the antelope to the poor range in the park during the past few years may in part have been due to poaching outside, although habit may have been a more important factor.

Sagebrush (Artemisia tridentata) forms the staple winter diet of the antelope. It is eaten at all seasons but in winter is particularly sought. In March, when the snowdrifts in the hollows had melted sufficiently to expose the tops of the sagebrush that had been protected by snow during the winter, the antelope were frequently seen wading into the drifts to feed on it, since elsewhere it was closely browsed. Atriplex oblanceolata is also an important winter food, especially if the snow is so light that it does not cover this low- 


\section{Fauna of the National Parks of the Lnited States}

lying plant. Although even more palatable than sagebrush, Atriplex oblanceolata is far less important as a winter food because it is much less abundant. Yellowbrush (Chrysothamnus), and greasewood (Sarcobatus vermiculatus), are frequently eaten but rate lower in palatability than sagebrush and Atriplex oblanceolata, and are not so widely distributed over the winter range. Russian thistle is heavily consumed wherever found.

Other species are eaten in winter, such as fringed sagebrush (Artemisia frigida) which would be of more importance if it were not so scarce. Discarded Douglas firs on the Mammoth dump, which had been used for Christmas trees, were eaten, but consumption of liv ng fir was not noted elsewhere. No fir is available except in fall or early spring on the edges of the range. In late fall and early spring some green grasses are available and are highly relished.

In winter, no evidence of feeding on dry grasses was noted; and if any grasses are eaten the amount is slight. It is important to remember this in order to avoid misleading calculations dealing with antelope food on winter range in Yellowstone. For instance, several years ago sagebrush on sample plots on the antelope range was grubbed out to learn whether the grass could be increased.

On the antelope winter range, considerably more than 75 percent of the sagebrush is dead as a result of overbrowsing. In some places there is not much evidence of its former presence but elsewhere the dead stalks stand or lie broken loose. Figure 36 shows the position of a fence along the old park boundary which from about 1902 to about 1932 prevented the antelope to some extent from moving out of the park. Although the fence has been removed the sagebrush is now largely dead on both sides of the old fence line but that to the north (right) of the line is more in evidence because it was overbrowsed later, therefore is not so broken down and some is still alive. Nearly all sagebrush on more recently acquired park lands as far as the new boundary at Reese Creek is dead.

In past years the antelope have generally been confined to the winter range within the park, and during the winter of 1937-38 only a few of them were ever seen below Reese Creek outside Yellowstone. In the winter of 1938-39 the antelope moved outside enmasse to better range north of Reese Creek. In November more than 200 were seen north of this creek, and on March 1, 1939, a total of 495 were counted there. No doubt some actually present were missed in the count. Shortage of food within the park was probably the main reason for the general exodus.

The poor range conditions in the park were aggravated by an unusually large amount of snow lying on the ground all winter. 


\section{Ecology of the Coyote in the Tellowstone}

At the present time, antelope are the heaviest utilizers of sagebrush on their range as a whole, but at the borders of the range deer consume large quantities. The deer range overlaps a portion of the antelope range, and since deer in winter are heavy feeders on sagebrush there is direct competition for food. A few deer may be found wandering out in the middle of the antelope range but most of them are found on the fringes, in the Game Ranch area and on the lower slopes of Mount Everts along the Gardiner River. Bighorn and antelope compete for sagebrush and other plants and now most of the sagebrush has vanished from the more exposed slopes where bighorn are found. Elk feed on sagebrush in small quantities, not from necessity but because they relish it, as shown to a certain extent by the fact that they eat it early in the fall before any snow has fallen, when other palatable foods are available. The quantity of sagebrush consumed by large bands of elk may be considerable. For some time, apparently, a number of elk have wintered on the antelope range and nearby and have probably contributed a little to the overbrowsed condition of the sagebrush. At the present time elk are attracted to the antelope range by fields of brome and wheat grasses, planted on the former cultivated lands at the Game Ranch in order to keep the soil from blowing away. During the winter of 1937-38 between 800 and 1,000 elk visited the fields each night, returning to the forested foothills for the day. En route to and from the fields, evenings and mornings, the elk browsed on sagebrush. It had been eaten so closely that there was little available, but enough elk were congregated to have done considerable damage if a good stand had been present. It is hoped that less luxuriant native vegetation may soon take over the hay fields which are now such an attraction to elk, whose presence there in large numbers is injurious to the antelope range.

\section{SPRING ACTIVITIES}

In April, and sometimes earlier, the antelope move up-country from the Game Ranch wintering area, while deep snowdrifts still lie in the hollows and on the north facing slopes. In summer they are distributed from the Game Ranch all the way to Tower Falls and to the high grassy ridges bordering Cache Creek on the east. They are commonly found on top of Specimen Ridge. In the summer of 1938 at least one hundred antelope stayed on the winter range in the Game Ranch area. These animals were thus remaining the year around on the same range. In August 1935, I saw three antelope in Hayden Valley. This occurrence was unusual, although in the early days the species regularly summered there. In early November the antelope move back to the winter range. 


\section{Fauna of the National Parks of the United States}

The fawns are born in late May and early June. On May 28, 1938, 10 of 12 does were still obviously heavy with calf; a day later a fawn was found; on the thirty-first most of the does seen, although scattered out singly, still seemed heavy with fawn; on June 4, three does were with fawns; on June 7 , two fawns were found which had been born during the day; on June 10 a doe, still heavy, was observed. It was my impression that by June 10 most of the fawns had been born, but that very few arrive before May 28. Twinning is not at all unusual. Between June 4 and June 11 six does were seen with twins and seven with a single fawn. Some of the does with a single fawn may have borne twins.

\section{MATERNAL PROTECTION}

The does travel together up to fawning time. As each doe feels the time approach she goes off by herself, but not necessarily far from the others, for often lone antelope may be seen only one or two hundred yards apart. A few days after birth of the fawns, the does begin to bunch up and soon the bands are together again. The fawns romp and rest together and when the band is traveling they are usually bunched. In June I have seen as many as seven fawns following one doe. On July 2, 1937, eight fawns were frolicking together two or three hundred yards away from the adults, and some of them lay down by themselves at that distance. When the fawns saw me they galloped away until they were about one-third of a mile from the adults. Here some of them lay down. At this time the young seem to be as fleet as the adults. They spend much time racing over the slopes and continue this frolicsome activity through cold weather. In late winter I have seen them lay back their ears and chase each other at great speed.

A new-born antelope fawn found June 7, 1938, measured between 16 and 17 inches in height at the shoulder; an accurate measurement was not secured because of difficulty in getting it to stand on its feet quietly. It could travel but did so with some unsteadiness. A day or two after birth the fawns travel quite well and soon move about freely with their mothers and the band. In early June fawns were frequently seen following their mothers.

The fawn has a strong instinct for hiding and lies motionless and limp when handled. It lacks spots and has a greyish-brown coat which makes it hard to find. On June 3 a doe, and a fawn which had been nursing, became frightened and galloped away. When the fawn came to a clump of sagebrush and cinquefoil it dropped beside it as though shot and lay still. It seemed to know the hiding possibilities offered by the vegetation. When it was lifted to its feet it galloped away to join its mother and dis- 


\section{Ecology of the Coyote in the Yellowestone}

appear over a ridge. It is my impression that antelope young get up and run away from disturbances at an earlier age than do the elk calves.

The protection the fawns receive from their mothers before they begin to travel to any extent with the bands is of importance in connection with the vulnerability of the fawns to predators. On June 4, 1938, I watched three does, each with two fawns, from 9:30 a. m. until 8 p. m. The does were on two rather gentle slopes of some low buttes east of Trumpeter Lake; one doe was alone on one slope and two does were together on the other. The following observations were made of the lone doe:

9:30 a. m... Two fawns were nursing. When finished they lay down a few yards away. There were two other does and a yearling nearby. The mother of the fawns followed one of the does to chase it away. After feeding in the vicinity of the fawns, the mother and the two does and yearling lay down near the top of the ridge about 150 yards from the fawns.

1:10 p. m... The mother approached the two fawns which had been lying about 30 yards apart, and they both nursed at once for about a minute.

1:20 p. m... The two fawns lay down 25 yards from where they had nursed and the mother fed slowly up the slope.

$2: 10$ p. m... She came in sight, and lay down near the top of the ridge from where she could see the fawns 150 yards below.

$4: 30$ p. $m$... The began to feed, always in sight of her fawns.
The fawns, lying 5 yards apart, rose, and the mother, who was 35 yards away, approached them. The fawns nursed together, one for 1 minute, the other for $1 \frac{1}{2}$ minutes. A few minutes later they both nursed again briefly. The mother spent some time licking them between the hind legs.

$4: 40$ p. $m$... The fawns lay down; the mother moved up the hill.

$5: 20$ p. m... The mother stood on top of the ridge peering down the other side.

$5: 25$ p. m. . She lay down on top of the ridge 150 yards above the fawns and in view of them.

6:00 p. m... She commenced to feed. Two heavy does and a yearling wandered near the fawns.

$6: 10 p . m \ldots$ A third doe wandered near where the fawns lay.

$6: 30 p . m$... The mother went over the ridge out of view.

$6: 45 p . m$. . She reappeared on the horizon and looked toward her fawns at intervals while feeding.

7:10 p. m... She moved out of sight of the fawns, but returned in a few minutes. For the next 50 minutes she fed back and forth across the slope in the general direction of her fawns.

8:00 p. m... She approached the fawns and both nursed together. Dusk prevented further observations.

During the period of $10 \frac{1}{2}$ hours that I watched, the mother was out of sight of the fawns for about 40 minutes. The inactivity of the fawns indicated that they were very young. 


\section{Fauna of the National Parks of the United States}

\section{Movement of does numbers 2 and 3:}

9:30 a. m... The two does, along with a third doe which appeared heavy, were feeding on a ridge.

11:00 a. $m$. Four grazing elk cows appeared on the slope. They, as well as the three antelope, peered up the slope at two elk calves, one of which had stood up. One of the antelope approached within about 20 yards of the calves, and one of the elk to within about 40 yards of them. The calf lay down and the antelope and elk began to feed. Three jackrabbits playing around two large boulders attracted the attention of the elk and antelope. The three antelope approached within 50 yards of the hares and the elk approached almost as near. The antelope disappeared over the ridge, along the crest of which they had been feeding. The elk grazed down the slope.

11:15 a. m. . An antelope fawn cried out and leaped away from the feet of one of the cow elk; the cow was startled and jumped to one side. I could not determine whether the fawn had been trampled. The fawn ran out of sight 200 yards away near the base of and around the ridge over which the three does had disappeared, but probably too low to be seen by them.

11:45 a. m. The elk went out of sight.

12 noon... The three does reappeared on the ridge at the place where they had gone out of sight. One of them was followed by two fawns and another by a singleton. All three fawns nursed. One of the fawns, after nursing from one doe, walked over to try the other and was gently butted away. After the three fawns had frolicked together about 4 minutes they lay down. One, rising to follow its mother, lay down when she turned abruptly and faced it. This fawn changed its resting place two or three times, moving only a few yards each time.

$12: 20 \mathrm{p} . \mathrm{m}$. . The doe with the single young came down the slope to the spot where the elk had startled a fawn. The doe smelled of the place and followed in the direction the fawn had taken for about 30 yards: it then turned down the hill and walked aimlessly here and there for about 25 minutes, bleating at intervals the whole time. She seemed to be searching for the fawn that had run away.

12:45 p. m. After returning again to the spot where the fawn had lain the doe walked up to her other offspring and lay down about 50 yards away from it. During this time the other two does had been resting a short distance above the three fawns.

2:10 p. m... All three does were feeding. An elk calf stood up and attracted the notice of one of the does 75 yards below.

3:15 p. m... Two of the does were resting 50 yards above the fawns, and the other was feeding. Then for 10 minutes the doe that had last fed searched for the lost fawn, going twice to where it had lain.

3:30 p. m... The two does fed their fawns, each fawn nursing about 1 minute. Before feeding started one fawn came 10 yards to meet a doe, which shied away after smelling noses with it and walked up to one of her own offspring. After she had fed this fawn, she walked toward the other one, which got up when she was 30 yards away and came to meet her. These two fawns scampered and played and then ran down the slope together. The fawn that had smelled noses with the strange doe was approached by its own 


\section{Ecology of the Coyote in the Yellowstone}

mother and nursed. This doe then searched for the lost one, returning again and again to where it had lain.

$3: 35 p . m .$. The lone fawn lay down.

3:50 p. m... The twin fawns lay down 35 yards from their mother. One of these in a few minutes got up to meet the other doe, then trotted 30 yards down the hill where it lay beside a rork. The doe smelled of this fawn, then returned to search for her lost one, crying at intervals. The bleat could be heard plainly 100 yards away. The mother of the two fawns fed about 140 yards away from them but remained in their sight.

4:00 p. m... The mother in search of her fawn went over the ridge in the direction in which it had disappeared.

4:10 p. m... The mother of the twins lay down 130 yards from them.

4:40 p. m... The mother returned to the slope from over the ridge and examined the spot where the lost fawn had lain.

4:45 p. m... One of the twins rose and followed the mother of the lone fawn as it wandered past; it then ran off 30 yards and lay down. This time the doe did not smell of it.

4:50 p. m... The mother of the lost fawn, after feeding in the flat, lay down.

5:30 p. m... The mother of the twins began to feed.

5:40 p. m... The mother of the lost fawn walked below the spot where it had been lying, and then looked over the ridge where it had disappeared.

7:00 p. m... Both mothers were resting within 100 yeards of their fawns.

7:10 p. m... The doe again examined the spot where the lost fawn had been lying. One of the fawns was seen looking around as it rested.

7:30 p. m... The two mothers were out of sight of the resting fawns for a few minutes; a heavy doe and a yearling had wandered near.

7:35 p. m... The two mothers and another doe romped a few minutes; one of the does ran about 150 yards in a big circle.

7:45 p. m... The mother of the lost fawn returned to sight after searching over the ridge for a few minutes. The other mother fed out of sight over the ridge.

7:55 p. m... A yearling cautiously approached within 6 feet of one of the fawns and then shied off. A pregnant doe did likewise but actually smelled of the fawn before wheeling away. The mother of twins came in sight of them again, after being out of their sight 10 minutes.

8:00 p. m... The mother of the lost one was bleating while she searched for her fawn. (There is some possibility that the "lost fawn" was the one which followed the mother over the ridge at noon but the behavior of the mother would indicate that the fawn was actually missing.)

From noon to $8 \mathrm{p}$. m. the doe searching for her fawn had been out of sight of her remaining one about 45 minutes. The other mother was out of sight of her fawns only about 10 minutes. It therefore appears that the mothers remain close enough to their offspring to watch for intruders most of the time when the fawns are young

On June 4 near Tower Falls I saw a doe looking at a spot 10 or 15 yards from her and upon investigation found a fawn. The doe ran off a hundred yards. When I picked up the little one it cried and brought the mother, on a dead run, to within 10 yards of me. I put the fawn down and it ran 


\section{Fauna of the National Parks of the United States}

off with its mother on unsteady legs. The mother was in this case quite fearless in approaching me when it felt its young endangered.

During the summer of 1937 fawn remains were found in 32 coyote droppings. This of course gives but little information on the number of antelope fawns which may be consumed by coyotes. Whether or not there is too heavy a drain on the fawns from all sources can only be determined by ascertaining the fawn survival. The counts as later reported showed a good survival, sufficient no doubt to increase the size of the herd. The proportion of the fawns that are eaten as carrion or are killed by coyotes is not known; but it is certain that some of the fawns represent carrion. Under "elk" I have discussed the general mortality of new-born ungulates. Among antelope there is also no doubt that a rather definite proportion of fawns die at birth or shortly thereafter. Ranger Ben Arnold reported finding on June 19, 1931 a dead doe antelope and two dead fawns, one born and the other still unborn, and attributed death to travail during fawning. When the mother has two fawns, it may occasionally happen that one is lost. The incident cited of a fawn antelope scared away from its bed by an elk on June 4 illustrates how a fawn might be lost. Whether this one was found by its mother I did not learn but it is possible that it was lost to later become carrion.

\section{RELATIONSHIPS OF BUCKS TO DOES AND FAWNS}

During the summer it is usual to find a buck with each band of does and fawns. The buck at this season may do considerable herding of the company. Many of the bucks are alone, or in groups of two to a dozen or more. About the middle of September the rut begins and a buck with a band of does and fawns chases away all other males. If not successful in this he hangs on the outskirts of a band, or possibly wanders from one band to another. Quite often during the summer bucks have been seen chasing single does. Sometimes the run is long enough to cause both animals to pant, with mouths open. To escape the buck the doe sometimes resorts to considerable dodging. Several times in late May a buck was observed chasing a heavy doe for a distance of about 500 yards. In winter the bucks and does intermingle in various proportions, and at that time the bands are frequently breaking up and re-forming. The presence of a buck with a herd of does might insure some added protection to the fawns from coyotes.

\section{FAWN SURVIVAL}

Season of 1937.--During the summer it is not always easy to get antelope counts showing true proportion of fawns, for at that time some of the fawns 


\section{Ecology of the Coyote in the Yellowstone}

or some of the does may be segregated by themselves, or several of the fawns may be following one or two does. On June 28, 1937, for example, seven fawns were following one doe. Another doe was followed by three fawns, two of them the same size, one definitely larger. At Yanceys, after making repeated counts, it was felt that a fairly good summer census of the does and fawns was obtained. Some of the more complete counts made at Yanceys are here tabulated. It will be noted that the early summer ratio was maintained throughout the summer. Yearling does are included under "doe" as it is hard to differentiate them.

Reliable counts made over same area at Yanceys

\begin{tabular}{|c|c|c|c|c|c|c|c|}
\hline 1937 & Buck & Doe & Fawn & 1937 & Buck & Doe & Fawn \\
\hline $\begin{array}{l}\text { June } 27 \ldots \\
\text { June } 28 \ldots \\
\text { July } 2 \ldots \\
\text { July } 3 \ldots\end{array}$ & $\begin{array}{l}8 \\
2 \\
1\end{array}$ & $\begin{array}{l}18 \\
12 \\
15 \\
13\end{array}$ & $\begin{array}{r}18 \\
10 \\
21 \\
9\end{array}$ & $\begin{array}{l}\text { July } 4 \ldots \ldots \\
\text { July } 9 \ldots \ldots \\
\text { Aug. } 7 \ldots \ldots \\
\text { Aug. } 29 \ldots\end{array}$ & $\begin{array}{l}7 \\
2 \\
4 \\
2\end{array}$ & $\begin{array}{l}16 \\
15 \\
14 \\
21\end{array}$ & $\begin{array}{l}20 \\
17 \\
13 \\
19\end{array}$ \\
\hline
\end{tabular}

Other summer counts were made but since they were not as comprehensive they may not represent true ratios existing in the areas:

\begin{tabular}{|c|c|c|c|c|}
\hline 1937 & Locality & Buck & Doe & Fawn \\
\hline July 6 & Specimen Ridge . ................... & 7 & 12 & 0 \\
\hline Sept. 29 & $\ldots \ldots$ do..... . & 0 & 1 & \\
\hline July 7 & Horseshoe. . & 2 & 21 & 15 \\
\hline July 9 & $\ldots$. do . .... & 4 & 26 & 18 \\
\hline July 8 & Cache Creek. . & 5 & 11 & 7 \\
\hline Aug. 6 & Buffalo Ranch. . & 17 & 28 & 8 \\
\hline Sept. 18 & $\ldots$. do. . . . . . & 10 & 11 & 5 \\
\hline
\end{tabular}

1 Apparently many yearlings.

The following tabulation shows results of two fall counts of the herd, each made over a 3-day period. There was only a slight possibility of counting any animals twice in either count.

First Count

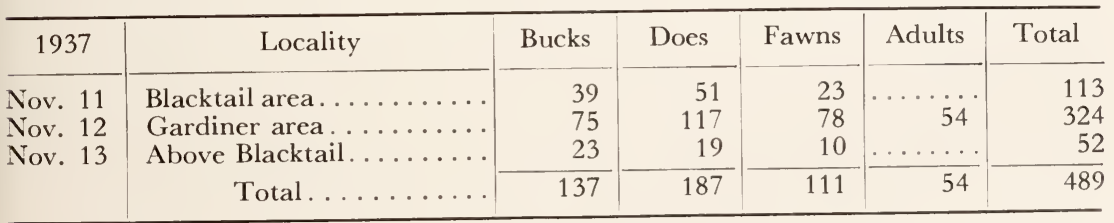

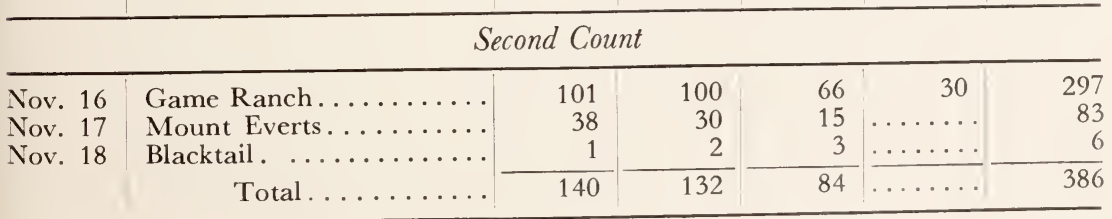




\section{Fauna of the National Parks of the Lnited States}

The ratios of adults to fawns in the two counts are 29 percent and 27 percent, respectively. It will be noted that a smaller proportion of bucks are tabulated in the first count than in the second. However, most of the 54 animals classified as "adults" were bucks (I did not have time to precisely differentiate the does and bucks before they ran off) so the doe-buck ratio was actually not very different in the two counts. The first sample represents more than half the antelope herd so the fawn ratio attained is fairly representative of the true ratio, especially since other ratios obtained in various counts during the winter lie so near this.

At various times between January 12 and May 3, 1938, animals on the winter range were classified when opportunity offered. Of 1,494 animals classified, with of course many duplications, 331 were fawns. This gives a 28 percent increase of fawns, a ratio midway between the percentages of 27 and 29 secured in the two large counts made in November. The sex of adults was identified only in a group of 443 animals, 173 being bucks with the same number of does, and 97 fawns. The percentage increase in this sample is also 28 percent.

The fawn survival during the winter was high. The ratio recorded for March, April, and May was about 4 percent higher than that for January and February. This fawn increase probably is not of statistical significance, but points to a high winter survival of young.

Season of 1938.-- On July 14, 1938, I counted at Tower Falls 1 buck, 28 does, and 12 fawns. This was an incomplete census of bucks, and may also have been incomplete for does and fawns.

On August 30, I was told by some of the local people that fawns were very scarce in the Gardiner area and that it was thought the coyotes were "getting all the fawns." I made a count between Gardiner and the Game Ranch with the following results: bucks, 13; does, 38; and fawns, 27 . The fawn ratio, rather than being low, was unusually high in this particular area.

The total of various counts made between July 14 and October 1 in the Gardiner, Blacktail, Yancey, Horseshoe, and Buffalo Ranch areas is as follows: bucks, 23; does, 126; and fawns, 63. If we consider the sexes of adults equal in number, which they appear to be, and assume the number of adults to be twice the doe count, the increase is about 25 percent.

Practically all of the antelope had moved down to the winter range by November 11, 1938, having come down a few days earlier than in the preceding year, probably because of the earlier arrival of cold weather and snow. Two hundred or more had moved outside the park below Reese Creek by the middle of November. One band was reported near Living- 


\section{Ecology of the Coyote in the Yellowstone}

ston, more than 50 miles from the park. These were seen some distance from any area where antelope were known to regularly occur. It was presumed by some people that they had wandered down from Yellowstone National Park, but the real source of these antelope was not known.

On November 12 I counted and classified 351 antelope. Of these, 202 were feeding in an alfalfa field. The fawns were no doubt especially fond of frozen alfalfa for the ratio of fawns to adults was much higher than among the antelope outside the field. On November 15 a second count was made. At this time there was still a concentration of fawns in the alfalfa field.

November 12 Count

\begin{tabular}{|c|c|c|c|c|}
\hline Location & Buck & Doe & Fawn & Total \\
\hline $\begin{array}{l}\text { Alfalfa field near Reese Creek ............... } \\
\text { Outside alfalfa field } \ldots \ldots \ldots \ldots \ldots \ldots \ldots\end{array}$ & $\begin{array}{l}66 \\
52\end{array}$ & $\begin{array}{l}65 \\
90\end{array}$ & $\begin{array}{l}71 \\
12\end{array}$ & $\begin{array}{l}202 \\
154\end{array}$ \\
\hline Total... & 118 & 155 & 83 & 356 \\
\hline
\end{tabular}

November 15 Count

\begin{tabular}{|c|c|c|c|c|}
\hline $\begin{array}{l}\text { Alfalfa field } \ldots \ldots \ldots \ldots \ldots \ldots \ldots \ldots \ldots \ldots \ldots \\
\text { Outside alfalfa field. } \ldots \ldots \ldots \ldots \ldots \ldots \ldots\end{array}$ & $\begin{array}{l}58 \\
55\end{array}$ & $\begin{array}{l}19 \\
77\end{array}$ & $\begin{array}{l}55 \\
32\end{array}$ & $\begin{array}{l}132 \\
164\end{array}$ \\
\hline Total & 113 & 96 & 87 & 296 \\
\hline
\end{tabular}

The sample count made on November 12 shows an increase in the herd, due to fawns, of 30 percent. Since there was a concentration of fawns on the alfalfa field, it is difficult to know whether a true ratio was secured. However, it is possible that enough animals were counted away from the field to compensate for this concentration. The buck count is considerably lower than the doe count so perhaps the adults were not fully represented. If the percentage of increase due to fawns is based upon the assumption that the adult herd contains as many bucks as does, or a total of 310 , then the increase is 26 percent.

The second count, made on November 15, is probably less representative than the first one, for there was still a concentration of fawns in the alfalfa field and a smaller number of animals were counted. The relatively high count of fawns away from the alfalfa field was due to finding one band containing a high fawn ratio which apparently had just left this field.

On February 27, 1939, 44 antelope were counted on Rattlesnake Butte, and on March 1, 519 were counted near the Game Ranch and outside the 


\section{Fauna of the National Parks of the United States}

park below Reese Creek. In the latter case 495 were outside the park. There probably was no duplication in these two instances so they are tabulated together.

February 27 and March 1, 1939. Counts

\begin{tabular}{|c|c|c|c|c|}
\hline Date & Buck & Doe & Fawn & Total \\
\hline 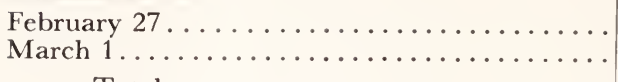 & $\begin{array}{r}22 \\
190 \\
\end{array}$ & 230 & $\begin{array}{l}13 \\
99 \\
\end{array}$ & $\begin{array}{r}44 \\
519\end{array}$ \\
\hline 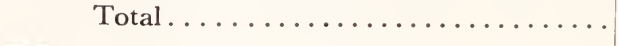 & 212 & 239 & 112 & 563 \\
\hline
\end{tabular}

As the count includes well over half the total number of antelope in Yellowstone Park it should represent a good statistical sample of the population. The increase in the herd due to fawns is 24.8 percent, this being a little less than the percentage increase in November counts and a little less than the percentage increase found in the 1937 fawns.

The survival of the 1937 and 1938 fawns appears to be sufficient to bring about an increase in the antelope population since losses of adults were apparently light.

\section{GENERAL CONDITION OF ANTELOPE}

A buck with a right hind leg broken near the calcaneum was observed on the summer range at Tower Falls in 1937 and 1938, and at Gardiner in the winter of 1937-38. Another buck with a stiff and slightly bent right foot was frequently seen at Gardiner during the spring and summer of 1938 , and in March 1939. Twice during the winter of 1937-38 a doe was seen limping badly.

On one occasion, January 27, 1938, I observed an old doe that seemed unable to keep up with the moving band. She traveled with great effort,

On February 7, 1938, a doe was seen stamping her hind feet alternately and occasionally lifting one of the legs and kicking it rapidly in the air. The action may have indicated an ailment.

Several of the does and fawns lost much of the hair from their necks. One doe in this condition seemed much agitated. Several times when seen she fed nervously and led the others away. On February 28, three fawns were seen with much hair missing from their necks.

The antelope came through the winter of 1937-38 in good shape; there were no animals seen which appeared sick except the old doe seen January 27.

On November 12, 1938, two does were extremely thin and poor in coat. On one of them the hair seemed stuck together and flattened close to the 


\section{Ecology of the Coyote in the Yellowstone}

hide. This one wandered restlessly all over the field apparently feeling uncomfortable. Both does probably died early in the winter. Two other does were observed, each with a decided limp in a front leg. On March 1, 1939, an extremely thin female was seen. However, the antelope generally were in good condition at this time.

\section{ANTELOPE DEATHS}

During the period between May 1, 1937, and May 1, 1938, the remains of 13 antelope were found. Except for remains of a fawn which apparently had died a day or two after birth, the carcasses were found on the winter range, and in the following months: one in November, one in February, two in March, five in April, two in May, and two in June. As is apparent, most of the animals had died in the spring.

In four cases only hair remains were found, so that sex and age of the animals were not determinable. Six others were old does, with teeth worn to the gums; in one case some teeth were also missing, and two of them showed a necrosis of the bone around the teeth (one of these two had also a necrosis on the tongue) three were old bucks with much worn teeth, and one showed much necrosis of the bone around the molars. Five of the animals were from about one-half to three-fourths eaten when found.

Although the death of several of these antelope was ascribed to coyote depredation by some of those who had seen them in the field, the evidence for such an assumption in all cases was totally lacking. The allegations were based on such observations as "it lay in a hollow where coyotes had probably cornered it." If coyotes had killed any of these animals whose condition was determined, then it was obvious that the coyotes were killing animals already doomed to an early death of old age or disease. It seems probable that the best deduction is that these animals died directly from old age and disease.

Rush (1932, p. 105), mentions examining 13 antelope specimens. Of these, six showed necrotic ulcers in the mouth; all showed decayed teeth to a greater or less extent; four were infested with lungworms, Dictyocaulus $s p$. , two with intestinal worms, Ostertagia sp., and Nematodirus antilocaprae, one with tapeworms, Moniezia sp., and all were infested with wood ticks. These antelope examined by Rush apparently had also died from old age and disease.

Early in October 1938 Ranger Grimm found on the Game Ranch remains of two dead animals that had been cleaned up by coyotes. In 1939 he found the remains of an adult buck soon after the shedding of its horns. There was a necrosis around one of the molars. 


\section{Fauna of the National Parks of the United States}

Marguerite L. Arnold (Yellowstone Nature Notes, January 1936) gives an interesting observation of a fight between two bucks in which one of the bucks was so badly wounded that it undoubtedly died. Mr. Arnold chased away the more powerful buck and the other "stood bleeding and almost completely disemboweled." Such casualties are probably relatively rare but show another cause of mortality.

\section{ANTELOPE-COYOTE RELATIONSHIPS}

During the winter of 1937-38, I obtained relatively little information on antelope-coyote relationships. While winter conditions over most of the park were unfavorable to the ungulates, the antelope fared well because of the light snowfall on their range, which lies in a tongue of the Upper Sonoran Life Zone. Much of their range was free of snow so that low vegetation, such as Atriplex oblanceolata, was more available than usual. The antelope were in fairly good shape and perhaps on that account, at least in part. no coyote depredation was observed. Furthermore, there was much carrion available, so coyotes were not hungry. Apparently coyotes sometimes run down antelope but the condition of the victim may be a factor in causing predation. The animal might be sick or aged. Since antelope and coyotes existed together in numbers in early days it seems probable that the antelope must be constituted to take care of themselves under usual circumstances.

Observations were made at various times which give some information on coyote-antelope relations. On May 14. 1937, a buck followed a coyote, at a brisk walk, for about 150 yards. The coyote was about 150 yards ahead of the buck. From across a swale the coyote stopped briefly to watch his pursuer. The buck began to feed but the white hairs on the rump remained raised for about 2 minutes.

On August 17, 1937, at Yanceys, Martin Murie watched a coyote trot towards four does, four fawns, and a buck lying in a swale. The antelope ran up the side of the hollow, then turned in unison and chased the coyote. When coyote and antelope disappeared, a couple of hundred yards away, the antelope were only a few yards from the coyote.

On June 8, 1937, about noon, high on the ridge north of Cache Creek, I saw a buck and two coyotes together on a bare promontory. At times the coyotes were only 4 or 5 yards from the buck. Once he nearly ran down one of the coyotes by making a sudden charge, and several times he pawed the earth and lowered his horns threateningly. Once the buck stood looking at a coyote in front of him while the other sat 4 yards behind him. For a few moments all three stood surveying the Lamar Valley 


\section{Ecology of the Coyote in the Yellowstone}

stretched out below and then the coyotes gradually moved off and out of sight. On an adjoining ridge a doe and fawn were resting about 200 yards apart.

On January 12, 1938, in the Turkey Pen, 24 antelope were resting 150 yards from where 2 coyotes were lying down.

Shortly before dusk on April 17, 1938, along Blacktail Deer Creek about $11 / 2$ miles from the road, I saw about 100 antelope galloping easily along an open ridge in a compact band. About 200 or possibly 300 yards behind the antelope sped a lone coyote. While the chase was in sight it seemed that the coyote was rapidly being left behind. I suspect that the antelope were running because of high spirits, and the coyote may have given chase for the same reason, unless perchance it was a pup who knew no better and was galloping hopefully. On September 17, 1938, a coyote passed within 50 yards of a doe and fawn without disturbing them.

Rangers have reported seeing coyotes chasing antelope. Such chases, however, may sometimes be unimportant, for often antelope take the slightest excuse to express their exuberance in dashing over the hills. Often an entire band, and especially fawns of the year, dash wildly about in play. It is possible that under unusual conditions a healthy adult antelope might be killed by coyotes, although I have no evidence as to this possibility. Isolated cases of adults being run down by coyotes are reported but usually the circumstances are not given or known, nor is the condition of the animal given. Thus an important element in the case is lacking.

\section{STATUS OF ANTELOPE}

The antelope in Yellowstone National Park have had protection for many years. The size of the population has undoubtedly been largely limited by the winter range. Poaching, still a factor when antelope leave the park, was no doubt important in earlier times. Bailey (1930, p. 30) states:

In 1908 about 2,000 were estimated in the park but during the following winter all but 25 escaped through the park fence below Gardiner and went down to the lower valleys, where at that time they were unprotected, and many never returned. In 1911 only 450 were counted in the park. In 1914, 600 were estimated in the park herd, and in 1916,500 . In the spring of 1917 most of these left the park and later, when driven back, only about 200 were accounted for.

Antelope counts made by rangers, 1934-38

\begin{tabular}{|c|c|c|c|c|c|}
\hline rear & Actual Count & Estimate & rear & Actual Count & Estimate \\
\hline 1934 & .. 321 & 700 & 1937 & $\begin{array}{l}\ldots \quad 600\end{array}$ & 627 \\
\hline 1935 & 419 & 750 & 1938 & 786 & 800 \\
\hline 1936 & 406 & 603 & & & \\
\hline
\end{tabular}

$193098^{\circ}-40-8$ 


\section{Fauna of the National Parks of the United States}

Although the antelope have prospered and increased during the last few years, as shown by the foregoing censuses and by the fawn counts made during the last 2 years, their future is nevertheless precarious because of the deplorable state of their winter forage within the park. As is so often the case, the crux of the problem is the winter range. Good antelope range exists outside the park boundaries, which the antelope have begun to utilize, but unless this range becomes public property there is no assurance that it will be available in the future. So the solution of the antelope problem involves more winter range, with perhaps fewer elk on it.

The present area now being used outside the park, together with considerable additional range farther north, should be set aside for antelope. If the antelope are to be confined to the winter range within the park there will undoubtedly be a drastic decrease in their numbers. The coyote is not at the present time adversely affecting the antelope, nor is it preventing them from increasing, even though the herd is existing on a much overutilized winter range. 


\section{Chapter VIII}

\section{BIGHORN IN RELATION TO GOYOTES}

\section{DISTRIBUTION AND NUMBERS}

UaH desirable information on the distribution of the bighorn (Ovis 1 canadensis canadensis) is still lacking. Although it is known that some of the animals on the Mount Everts winter range summer on Mount Washburn, it is not definitely known where the remainder spend the summer except that some of the rams move to the Gallatin Range. Neither is it definitely known where the bighorn wintering in the Tower Falls area spend the summer. Winter and summer distribution in the northeastern section of the park is not well understood. Much of this information will be important in analyzing the status of the bighorn.

Bighorn are known to winter in the Mount Everts area, along the Yellowstone River from Gardiner to Quartz Creek, on parts of Specimen Ridge away from the Yellowstone River, on Druid Peak, and on Mount Norris and in some nearby peaks. The heaviest concentration of bighorn in winter is in the Mount Fverts area, which includes parts of Terrace Mountain and Rattlesnake Butte. Some of these animals wander outside the park on either side of Bear Creek.

On the winter range along several miles of the Yellowstone River between Gardiner and Quartz Creek the bighorn are widely scattered except on the ledges along the Yellowstone River between Little Buffalo Creek and Quartz Creek where probably 60 or more animals can usually be found. In the winter of 1937-38 I saw 17 bighorns on Druid Peak and in the winter of 1938-39 the rangers reported seeing 21 animals in this area, as well as about 30 on Mount Norris and surrounding peaks. The bighorn on Druid Peak and in the Mount Norris area winter up high although most of the others are wintering lower down. The important factors determining the winter range of the bighorn seem to be an available food supply and the presence of cliffs. Much of the range is wind blown, although in some areas the snow does not lie deep. The bighorn paw readily for food and, if feed is present, some snow does not handicap them greatly.

In summer a band of about 30 ewes and usually some young rams are found on Mount Washburn. Some of the old rams from the Mount Everts 


\section{Fauna of the National Parks of the United States}

winter range move into the Gallatin Range for the summer and ewes have been reported summering in these mountains. A number of bighorn summer in the northeast corner of the park but their distribution is not known in detail. Some occur on Cutoff Peak and others in the mountains east of Soda Butte Creek.

It is my impression that the number of bighorn in the park has not varied much in late years. The annual counts have shown an increase but it is probable that this is in part at least a result of more complete counts. However, the animals are holding their own and may possibly be increasing. With the discovery of additional bands in the park in the winter of 1938-39, there will probably be a further increase in the annual census for that year. The official count as made by rangers in the park is as follows for the past 5 years: 1934 (125); 1935 (126); 1936 (118); 1937 (175); 1938 (175).

The number of bighorn in the park is no doubt less than in early times. Large numbers were once found in the Hoodoos on the eastern edge of the park. This was a favorite hunting ground. Many bighorn once lived on the Trident in the Upper Yellowstone Region. Early hunting probably destroyed most of these animals and apparently eliminated bighorn populations which by habit ranged in areas where none are now found.

\section{GENERAL CONDITION OF BIGHORN}

In 1937 lambs and some ewes were noted coughing in early August and from that time through the winter months. On September 16, 1938, four of five lambs seen on Mount Washburn coughed violently and frequently, and, in some spells, 20 or more times successively. The coughing suggests a heavy infestation of lungworms. Mills (1937, p. 211) examined the lungs of a 5-year-old ewe and a 4-year-old ram from Mount Everts in the winter of 1934-35, and reported a heavy lungworm infestation in each case. He wrote: "In both cases the lungs bore numerous abscesses, and smears indicated the presence of multitudes of lungworm larvae." Two kinds of lungworm were involved, Protostrongylus stilesi and Elaphostrongulus odocoilei.

Marsh (1938), in reporting on several autopsies and bighorn disease investigations, states that lungworm is a primary etiological factor in one type of pneumonia, and the organism Corynebacterium pyogenes in another type. Potts (1938) in Rocky Mountain National Park also reports these two types of pneumonia. The severe coughing noted among the lambs on Mount Washburn indicates that they may be in danger of pneumonia. Their coughing is so severe that it seems that the physical condition of the lambs would be considerably affected by whatever organism causes the affliction and that the weaker ones are probably subjected to pneumonia. 


\section{Ecology of the Coyote in the Yellowstone}

If some parasite is involved the condition existing on Mount Washburn may favor its spread, for the movements of the bighorn are here considerably restricted by the salt still remaining on the ground which was formeriy salted. This thought, however, has not been demonstrated.

Some lambs are doubtless not physically up to par when born. On August 7, 1937, a lamb with its right eye swollen shut was seen on Mount Washburn. This lamb was runty, feeble, and indisposed to activity so that it lagged behind the band when the animals were traveling. It was easily approached on the blind side. Death probably soon claimed it, as it was not seen on the winter range in November. On November 8, 1937, a 3 -year-old ram was noted which was blind in the right eye. His general condition was not healthy.

On November 21, 1937, near the cliffs along the Yellowstone River opposite Tower Falls I saw an extremely small lamb with five ewes, three yearlings and a young ram. The band dashed out of sight leaving the lamb following some distance behind. A half hour later when I again saw the band the runty lamb was missing. The band was seen the following day and the runty lamb was still missing and was not seen again that winter. It apparently was not physically capable of moving with the band. The day it was lost I tried tracking it but the area was so trampled over by elk that I lost the trail.

Scabies, caused by the mite (Psoroptes communis ovis), is not uncommon in the bighorn and seems to cause the death of a few of the animals. In the winter of 1937-38 on Mount Everts, two 3-year-old rams and one 2-yearold ram had lost much hair over the sides of the body, and behaved as though they were not well. Another ram about 2 years old had lost the hair on one side of the neck, and was seen foraging by himself. One of the rams afflicted with mites and seen alone on January 16 died later in the month. It is possible that the others died for they disappeared in late winter.

At Junction Butte on January 22, 1938, I saw a ewe in a rough coat and a lamb which apparently had scabies in the region of the tail. A lamb, which appeared to be this individual, was seen again on May 9, 1938, and it looked sick. It was humped up and very thin and the loss of hair over the tail region was more noticeable.

In the spring of 1939 between February 25 and March 7 several animals were noted which were not in good condition.

An old ram which had been feeding along the Gardiner River near Gardiner for a couple of months was extremely thin and stood humped up much as did one of the previous year, which later died. A 3-year-old ewe 


\section{Fauna of the National Parks of the United States}

on Mount Everts was blind in the right eye, very thin, and in a rough coat. She was quite restless.

A 3-year-old ram, seen on Mount Everts, was emaciated and in poor coat. It appeared to be infested with mites.

A ewe near Bear Creek, outside the park, was thin and in rough coat. It is likely that these four last-mentioned animals died during the spring. A thin ewe followed by a lamb seemed to have a lame shoulder. She limped, with her body at an angle so that the hind legs tracked to one side of the fore legs.

The Mount Everts winter range was more heavily grazed in the spring of 1939 than I had ever seen it. Still the bighorn seemed to be in fair shape, although they appeared thinner than usual. All lambs, except one, seemed to be in good health.

\section{BIGHORN DEATHS}

Definite records of five dead bighorn were secured during the winter of 1937-38 and I was told that some had been poached outside the park. The amount of bighorn carrion available for food is relatively small. The following is a record of animals found dead.

February 6, 1938, a young ram, about 3 years old, was discovered on the Gardiner River. When first reported by workmen about January 30, the carcass was lying in a small cave located at the base of a perpendicular clay bank near the water. Pieces of the hide were sent to Dr. Harlow B. Mills at Bozeman, Mont. who reported the presence of mites on all samples. On January 16 I had seen a young ram a short distance from the spot where the dead animal was found, and I have no doubt that it was the same individual. When I saw it alive most of the long hair on one side was missing. The fact that this ram was living alone indicated he was sick and lacked the inclination to travel normally in the company of the others.

On February 10 along Glen Creck below Golden Gate I found the carcass of an old ram which had been dragged off a knoll by a coyote. As the meat was not yet frozen, it had not been dead long. The ram was thin, its teeth were worn to the gums, one molar and two incisors were missing, and one incisor was almost worn through from one side. There was some necrosis around the molars. The animal had apparently died from old age.

On March 1, the bones (excepting the skull) and hair of an old ram were found in a gully along the Gardiner River. The animal had probably died from old age or discase.

On April 5, 1938, the remains of an old ram, which I photographed alive on March 26, were found along the Gardiner River. The photograph 


\section{Ecology of the Coyote in the Yellowstone}

(fig. 38) shows its emaciated condition. Principal cause of death was probably age.

On May 9 some hair remains of a sheep were found on the rim of the Yellowstone River near Quartz Creek.

To summarize: three of the deaths recorded here were probably due to old age, one to mites, directly or indirectly, and one to an unknown cause.

During the winter of 1938-39 one lamb was killed by a car and two rams were reported illegally shot outside the park boundaries. Other casualties, not reported, no doubt occurred.

Apparently bighorn occasionally lose their footing and are thus accidentally injured. A 3- or 4-year-old ewe found in Flat Creek in Jackson Hole was brought intact to O. J. Murie in Jackson. The animal was very fat. The two men who carried the sheep in declared coyotes had killed it, for one of them had shot a coyote at the still-warm carcass. The entire animal was skinned out. There was not a bullet hole or tooth hole in the skin. There were heavy bloodclots under both jaws (skin not broken), and one thigh was badly bloodclotted. Around the opening in the abdomen where the coyote had been feeding was some dried blood in the hair. Evidently there had been a hole there, and that is where the coyote began to feed. Clearly the animal had fallen, perhaps off a cliff, resulting in these serious bruises and actually puncturing the abdomen. It probably went down to the water, feverish, never got up, and a coyote had promptly found it.

During the winter of 1934-35 Dr. Harlow B. Mills (1937) reported the following losses: Shot illegally by hunters, 8; died from shot wound, 1; pneumonia, 1; accidental (cars), 3; collected for study, 1; unknown, 1.

The dead animals recorded in this section and the records of those suffering from ailments and infirmities in the preceding section show the causes of some of the normal losses suffered by the bighorn population.

\section{LAMB SURVIVAL}

If coyotes were preying on bighorn, lambs would be the main victims, so a particular effort was made to determine lamb survival. There are, of course, many factors other than the coyote which might reduce the lamb crop so survival of lambs is not necessarily a criterion of coyote predation.

Knowledge of the lamb survival is, however, one of the first steps in learning what factors are important in maintaining the population. This phase of the study deserves much more time than I have been able to give 


\section{Fauna of the National Parks of the United States}

it, but I feel that sufficient information was gathered to indicate some of the probable relationships between coyotes and bighorn.

It should be recognized that there are some difficulties in making a lamb census in winter, and in classifying the yearlings and older animals. Frequently I have found yearlings mistaken for lambs, and yearlings might at times be mistakenly classified as older animals. Lambs vary greatly in size. I have seen a male lamb in winter that was actually as large as a female yearling traveling with the same ewe. I do not wish to overemphasize the difficulties, for after some experience most of the animals can be rather readily classified, even though an animal will often be found which requires careful scrutiny and comparison to be properly identified. The general tendency is to identify yearlings as lambs.

Although I have quite a number of figures on lamb survival, I have omitted discussing several aspects of this question, especially survival of yearlings, feeling that further data are needed.

Season of 1936.- Few observations were made of the 1936 lambs and those were not made until the following spring. On May 16, three ewes, three lambs, and three young rams were seen at Junction Butte. Ranger Condon reported 32 ewes and 28 lambs in the Junction Butte region during the winter of 1936-37. This seems to be a high lamb ratio and possibly a few yearlings were classified as lambs, but as Ranger Condon is an excellent observer I am inclined to believe in the accuracy of his observation. Careful checking in the spring by Condon showed the loss of only one of the 27 lambs and this one was reported killed by coyotes. The condition of the animal at the time it was eaten was not known. Coyotes were plentiful on this bighorn range and were suffering from a shortage of food, yet they apparently preyed on only one lamb during the entire winter and this one may have been sickly.

Season of 1937.- During the summer, three counts, the last one quite complete, were made of the bighorn on Mount Washburn. These animals apparently winter on Mount Everts.

\begin{tabular}{|c|c|c|c|c|}
\hline 1937 & Rams & Ewes & Yearlings & Lambs \\
\hline 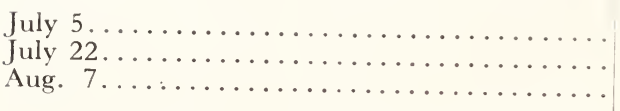 & $\begin{array}{l}2 \\
6 \\
5\end{array}$ & $\begin{array}{l}11 \\
17 \\
23\end{array}$ & $\begin{array}{l}1 \\
7 \\
3\end{array}$ & $\begin{array}{l}10 \\
15 \\
21\end{array}$ \\
\hline
\end{tabular}

In November some representative counts of the sheep on Mount Everts were made and additional counts were made later in the winter, as follows: 


\section{Ecology of the Coyote in the Yellowstone}

\begin{tabular}{|c|c|c|c|c|c|}
\hline Date & Rams & Ewes & Yearlings & Lambs & $\begin{array}{l}\text { Unde- } \\
\text { termined }\end{array}$ \\
\hline 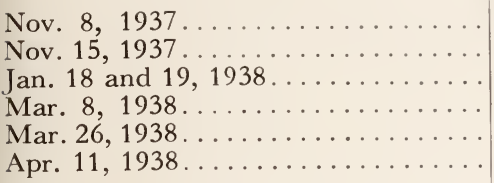 & $\begin{array}{r}4 \\
7 \\
43 \\
9 \\
8 \\
2\end{array}$ & $\begin{array}{r}23 \\
130 \\
40 \\
48 \\
28 \\
18\end{array}$ & $\begin{array}{r}10 \\
6 \\
6 \\
7 \\
5 \\
3\end{array}$ & $\begin{array}{r}10 \\
8 \\
13 \\
10 \\
9 \\
9\end{array}$ & $\begin{array}{l}\cdots \cdots \\
\ldots \ldots \\
\ldots \ldots \\
\ldots \ldots \\
\ldots \ldots\end{array}$ \\
\hline
\end{tabular}

1 Includes yearlings.

Although the wintering bands on Mount Everts are composed of those summering on several ranges, including Mount Washburn, still the winter lamb count is only about half the summer count of lambs on Washburn alone. The ewe count is larger, as would be expected.

The various counts strongly suggest that there was an appreciable loss of lambs occurring sometime between late summer and the month of November. If predators were responsible for the loss, one would expect losses during the summer when the lambs are most helpless, and also during the winter months, when, as will be shown, there was no noticeable loss. It may be that the lambs that are seen coughing considerably in summer succumb in the late summer and fall. In September 1938 a sick lamb was found on the Gros Ventre Range by a hunter. This incident is in accord with conclusions that may be drawn from the observations made in Yellowstone. Marsh (1938) reports lambs dying at the National Bison Range from acute pneumonia at the age of 2 or 3 months. Another possibility is that the added exertion entailed by migration eliminates the weaker animals during that period, thus reducing the weaker animals over a short period rather than over a long one. It might be suggested that the bighorn in their migration are at times more vulnerable to coyote attack through being away from protecting cliffs. Vulnerability to predation while on cliffs is very low; nevertheless, even on the summer and winter ranges, bighorn are often in contact with coyotes when away from crags. They apparently are able to protect themselves from coyote attacks if necessary when not among cliffs.

The fawns which were on the winter range on January 18 apparently suffered little or no loss during the remainder of the season. On that date 40 ewes, 6 yearlings, and 13 lambs were counted. A few days before the count of 28 ewes, 5 yearlings, and 9 lambs was made on March 26; 4 ewes with 2 lambs were noted at Bear Creek, and 8 ewes with 2 lambs were 


\section{Fauna of the National Parks of the United States}

seen on the north slope of Rattlesnake Butte. It is almost certain that these bighorn had spread out from Mount Everts and therefore in late March there were still about 13 lambs in the Mount Everts population, the same number as in January.

At Junction Butte and vicinty, the following counts were made in the winter of 1937-38:

\begin{tabular}{|c|c|c|c|c|c|}
\hline Date & Rams & Ewes & $\begin{array}{l}\text { Year- } \\
\text { lings }\end{array}$ & Lambs & $\begin{array}{l}\text { Uniden- } \\
\text { tified }\end{array}$ \\
\hline $\begin{array}{l}\text { Nov. } 22,1937 \ldots \ldots \ldots \ldots \ldots \ldots \ldots \ldots \\
\text { Jan. } 22,1938 \ldots \ldots \ldots \ldots \ldots \ldots \ldots \ldots \ldots \\
\text { May } 9,1938 \ldots \ldots \ldots \ldots \ldots \ldots\end{array}$ & $\begin{array}{r}4 \\
7 \\
212\end{array}$ & $\begin{array}{r}7 \\
118 \\
19\end{array}$ & $\begin{array}{l}1 \\
3\end{array}$ & $\begin{array}{l}2 \\
2 \\
2\end{array}$ & $\begin{array}{r}11 \\
10\end{array}$ \\
\hline
\end{tabular}

1 Includes yearlings.

2 Includes 2 young rams.

Apparently the bighorn distribution in 1937-38 varied from that of the preceding winter. This is not surprising in view of the great difference in snow conditions. The counts, I feel, are incomplete for this area but the figures, as far as they go, indicate the winter survival of the two lambs seen on the range on November 22.

During the winter of 1937-38 a total of 193 bighorn was counted and, of about 146 classified into age and sex groups, only 19 were definitely recognized as lambs. There was some possibility of duplication in individuals counted, but it is considered small.

Season of 1938.-During the summer, counts of the bighorn on Mount Washburn were made, two of which were rather complete.

\begin{tabular}{|c|c|c|c|}
\hline 1938 & Ewes & Lambs & Yearlings \\
\hline 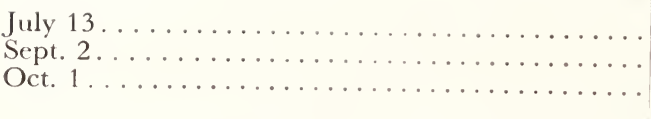 & $\begin{array}{r}27 \\
130 \\
6\end{array}$ & $\begin{array}{r}18 \\
18 \\
3\end{array}$ & $\begin{array}{l}2 \\
\cdots \cdots \cdots \cdots \\
\cdots \cdots \cdots\end{array}$ \\
\hline
\end{tabular}

${ }^{1}$ Includes yearlings.

It is evident that the lamb survival during the summer was excellent for the lamb counts made on July 13 and September 2 are the same.

I saw several coyotes near the bighorn on Mount Washburn. The fire guard saw coyotes near them all summer and expressed concern over the safety of the lambs with coyotes so common on the mountain. Of 21 


\section{Ecology of the Coyote in the Yellowestone}

coyote droppings found on the bighorn range on Mount Washburn, none contained bighorn remains.

In the summer of 1938 not a single young ram, older than a yearling, was seen on Mount Washburn, while the preceding summer as many as six were found. It is possible that the young rams were off by themselves, although one would expect them to be found near the ewes. The young rams seem especially susceptible to scabies. One was known to have died from this affliction, and others were affected the preceding winter. It is likely that some of the young rams in the Washburn population had succumbed to the disease.

During the winter of 1938-39 the following counts were made of bighorn wintering on Mount Everts and on Junction Butte in the vicinity of Tower Falls.

\begin{tabular}{|c|c|c|c|c|c|}
\hline Date & Location & Rams & Ewes & $\begin{array}{l}\text { Year- } \\
\text { lings }\end{array}$ & Lambs \\
\hline $\begin{array}{l}\text { Nov. } 11,1938 \ldots \ldots \\
\text { Nov. } 17,1938 \ldots \ldots \\
\text { Nov. } 21,1938 \ldots \ldots \\
\text { Feb. } 27,1939 \ldots \ldots \\
\text { Nov. } 30,1938 \ldots \\
\text { Mar. } 3 \text { and } 4,1939\end{array}$ & 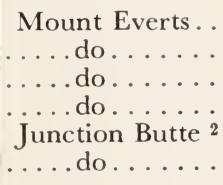 & $\begin{array}{r}7 \\
11 \\
14 \\
12 \\
4 \\
4\end{array}$ & $\begin{array}{r}144 \\
38 \\
44 \\
45 \\
20 \\
15\end{array}$ & $\begin{array}{c}5 \\
6 \\
3 \\
\ldots\end{array}$ & $\begin{array}{r}19 \\
23 \\
23 \\
17 \\
8 \\
2\end{array}$ \\
\hline
\end{tabular}

${ }^{1}$ Includes yearlings.

2 Very incomplete count.

The number of lambs that appeared on the winter ranges in 1938 was about twice the number that came down in 1937. The yearling count was smaller in November 1938 than it was the preceding year. This correlated with the poor lamb crop in 1937 and the apparently high survival in 1936.

On Mount Everts the November lamb count was 23 and the late February count was 17, indicating a possible loss of 6 lambs. It is possible that a few lambs were overlooked for during this period several ewes with their lambs had been seen apart by themselves. They thus may have wandered away from the area where the count was made. A winter survival of 17 of the 23 lambs is satisfactory, and seems especially high after one has examined the poor range utilized. Although all but one lamb seemed to be in fair condition in early March, it is likely that the weaker ones had succumbed. The emaciated lamb seen may also have failed to survive the remaining part of the winter.

The lamb count at Tower Falls was very incomplete. The two lambs were seen with lone ewes off by themselves a half mile and a mile away from 


\section{Fauna of the National Parks of the Lnited States}

the other bighorn, so that it appeared some of the ewes with lambs were living alone. A more extensive count may have revealed other lambs. The figures are too few to compare with the earlier count, which was also small.

If coyotes were an important enemy of bighorn on the winter range one would not expect the high survival of lambs found on Mount Everts during the winters of 1937-38 and 1938-39, for coyotes during both years were abundant in that area. As the bighorn on Everts were frequently found feeding over a quarter of a mile from cliffs, they would have been vulnerable to attack if their safety depended entirely upon cliffs. Although the bighorn often retreat to cliffs when coyotes, man, or any other source of danger is discovered, they sometimes simply bunch up in the face of such danger. The latter action under ordinary circumstances probably is sufficiently protective to make them safe from coyote attack. It is particularly significant that there were no lamb losses so far as known on Mount Washburn during the summers of 1937 and 1938 even though coyotes were common on this summer range and were frequently seen near the bighorn. It is important to consider that much of the time these animals were feeding on open slopes away from any cliffs.

\section{LAMB-EWE RELATIONSHIPS}

During the summer the lambs often draw together within a band. A ewe is frequently followed by one or more lambs which do not belong to her. Mothers may leave their lambs with other ewes and go off by themselves to feed. On August 7, 1937, a ewe that had been resting 300 yards from her offspring returned to it, "baaing" when I disturbed the group in which she had left her lamb.

The lambs remain with their mothers through the winter, and are frequently seen nursing during that season. The latest date on which nursing was observed was February 27. On this occasion the mother touched a lamb lightly on its side with a front foot whereupon the lamb turned and nursed, butting vigorously. Yearlings are sometimes found with a ewe during the summer and fall when they are almost a year and a half old.

Although I have seen a ewe followed by two or more lambs. I have never been sure of an instance in which more than one lamb was her own.

\section{BIGHORN-MAGPIE RELATIONSHIPS}

The magpie is probably not an important factor in the status of bighorn, but may be of more significance than is now apparent. There have been cases when domestic sheep have been harmed by the magpies pecking at wounds, enlarging them and keeping them raw. No instance of this kind 


\section{Ecology of the Coyote in the Yellowestone}

of magpie activity was noted on the bighorn. However, on a number of occasions magpies were found perched on them, busying themselves chiefly around the tail region and in the ears. I tried several times to collect a magpie immediately after it had been feeding on a bighorn but without success. Since mites are often present in great numbers in the ears and also over the body, it seemed probable that the magpies were feeding on these parasites. The bighorn usually acted as though they were oblivious of the presence of the birds but occasionally seemed to resent it. Once a young ram turned suddenly and tried to butt the bird. If the magpies are feeding on mites, their actions are beneficial to the bighorn.

It might be mentioned that magpies are also frequently found perched on elk and deer. At Wind Cave National Park one of these birds was seen perching on a bison. The stomach contents of a magpie collected near some deer consisted of three engorged ticks and the intestinal contents consisted of tick fragments. Ticks were found in the stomach of a magpie found dead. The tick infestation on the elk and deer is so heavy that the activities of the magpies can hardly be sufficient to reduce the infestation materially, but certainly this habit tends to be beneficial to the elk, deer, and bighorn. Moreover, in the case of bighorn, if the magpies consistently seek out the ear mites, which are troublesome to many of these animals, the birds are performing important service.

\section{BIGHORN-COYOTE RELATIONSHIPS}

During the winter of 1936-37, according to Ranger Condon, of 28 lambs in the Junction Butte area all but one survived. One yearling in late spring was reported killed by coyotes. The soft snow conditions prevalent all winter made travel difficult for coyotes, thus putting them at considerable disadvantage in hunting.

On November 21, 1937, I watched a band consisting of five ewes, one young ram, one lamb, and three yearlings lying on a low knoll 60 yards from the precipitous cliffs opposite Tower Falls. A coyote appeared over a rise 60 yards from the animals and walked slowly toward them. The bighorns watched it for a few moments, then all but a ewe arose (she also arose a moment later) and galloped toward the cliffs, stopping near the brink to feed, after briefly watching the coyote. The latter continued on its course parallel to the cliffs.

On Mount Washburn coyotes were frequently seen near the ewes and lambs summering there, but seemed not to molest them.

On Mount Everts on November 17, 1938, there was a band of eight large rams standing close together and about 40 ewes and lambs spread out on 


\section{Fauna of the National Parks of the United States}

the open slopes below them. Suddenly all the ewes and lambs started running, assembling in two bands. They watched a coyote that had trotted into view and was on his way down one slope and up another slope near the bighorns. A lamb that had been off by itself some 60 yards away galloped up to the band of rams and stood among them. Here it gazed after the coyote, which passed within 100 yards of the ewes. As soon as the coyote was out of sight, the lamb joined the ewes and other lambs who immediately spread out to feed again.

On November 21, 1938, on Mount Everts, a coyote trotted past 50 or 60 bighorn, which ran together in groups and watched the coyote until it passed out of view. Later in the day, a lone deer came trotting up the same slope. The bighorn became as startled as when the coyote had appeared, and assembled at a gallop into two groups. As the deer approached one group, the sheep hastened down the slope. The deer followed them, jumping, and seeming as bewildered as the bighorn. They stopped on a bench, the bighorn moving away from the deer, which soon went over the rim. In view of this last incident, it is a little difficult to interpret the reactions of the bighorn toward coyotes. It is probable that the former. especially the lambs, must run together for protection from coyotes or other predators. The deer was an unusual intrusion on the slope, so the bighorn behaved as they would if any potential enemy were approaching. Once a flock of about 150 rosy finches swooped down over four ewes, causing them to break into a gallop. The reaction of bighorn to any startling occurrence, including coyotes on some occasions, may be a measure of protective reaction to prevent predation.

H. B. Mills (1937, pp. 205-12) wrote concerning predation:

Losses from predators must be quite small on the winter range. The abundant coyote is at present the only predator of any importance to the sheep in the park. Although coyotes were commonly seen about the bighorn, there was no actual evidence that they made attacks on the flocks.

\section{STATUS OF BIGHORN}

During the winter the bighorn, especially in the Mount Everts region, subsist mainly on grass, but also feed on a variety of shrubs and trees such as willow, greasewood, sagebrush, fringed sage, yellowbrush, and Douglas fir. The stomach contents of a ram that died near Golden Gate consisted of 50 percent Douglas fir, and animals were several times seen feeding on fir branches which had fallen to the ground. Sagebrush and other shrubs were eaten extensively in November before snow had fallen on the grasses, and on Junction Butte and vicinity large quantities of yellowbrush were eaten during early November. 


\section{Ecology of the Coyote in the Tellowstone}

In winter, the bighorn are in direct competition with the elk for practically all food plants, and with the deer and antelope for the browse plants where their ranges overlap. The competition for food each winter is severe. On Mount Everts the bighorn during the last half of the winter subsist on a range so heavily utilized that the elk for the most part avoid it, after taking the "cream" of the forage. The bighorn in late winter pick at discarded seed stems lying on the ground and at the already closely grazed grass. The natural diet of the bighorn is more varied than the present vegetation on Mount Everts permits. A diet of greater variety would probably be more balanced in food values and result in healthier animals more resistant to diseases.

The grass slopes of Mount Everts were apparently once largely covered with sagebrush, remnants of which still remain in the form of dead roots and broken stalks. Now sagebrush is found only in hollows and ravines protected in winter by heavy snows. Destruction of the sagebrush was brought about by the combined feeding of bighorn, antelope, deer, and elk. When present it served to insure a good grass growth by retaining the snow, and shading the ground in summer so that surface evaporation and run-off were retarded. The nearly complete utilization of the grass each winter is adversely affecting the grass stand and is increasing erosion. A protected plot on the Mount Everts range showed clearly, in the fall of 1938, that heavy grazing was deteriorating the grass stand. The grass within the plot which had not been grazed for about 4 years was luxurious, while that outside was sparse and showed poor growth. So heavily is the range grazed in winter that no dead vegetation is left on the ground to retard runoff and evaporation during the growing season. Hence the growth is poor if moisture does not fall regularly. As a result of the heavy grazing on the range, not only is the grass stand deteriorating but sheet erosion is quite evident. The heavy use not only affects the bighorn's supply of food each winter but also reduces the permanent carrying capacity of the range.

In the Tower Falls area, Douglas fir on the bighorn range is overbrowsed, but the grasses and low plants are not greatly injured. They are protected from over use by deep snows and a smaller concentration of animals, and the cooler climate makes them less subject to drought and heat during the growing season. On this range the bighorn suffer somewhat through other forms of competition from the elk. In the fall of 1937 large bands of elk were seen feeding on grasses and yellowbrush on the narrow strip of range along the rock rim above the Yellowstone River, which is the important part of the range for bighorn. Although the vegetation was only 


\section{Fauna of the National Parks of the United States}

partially consumed, enough was eaten to make considerable difference to the animals when they pawed through the snow for food in midwinter.

Condition of the ranges is an important factor to consider in discussing the status of the bighorn. Disease, in many cases, is the result of poor range, and poor range would probably always augment the extent of disease. As yet the effect of poor range on bighorn reproduction is unknown. There is a possibility that inadequate nutrition in winter might reduce the lamb crop or produce lambs with lessened vitality. The bighorn are afflicted with mites which each year destroy a few animals. Many, especially the lambs, have a severe cough, the causative organisms of which may also be taking its toll. To minimize the effects of disease it is important to improve the range and to discourage congestion of the animals over a small area for any length of time. Resort to such devices as salting should be avoided.

Poaching is a factor in holding down the number of bighorn on the Mount Everts area. A few bighorn occasionally move outside the park into territory along the Yellowstone River where the animals are known to have been poached in the past. As many as 15 animals consisting of nine large rams, three ewes, two lambs, and one yearling have been seen outside the park at one time. During the winter of 1934-35, eight from the Mount Everts population were killed by poachers just outside the park, and another died from shot wounds. Some bighorn were said to have been illegally shot during the winter hunting season of 1937-38. Later I found no evidence of bighorn poaching but did discover in the areas occupied by bighorn just outside the park boundary, the legs and head of a fawn deer that had been slain in the early spring. Two rams were reported illegally killed outside the park in the winter of 1938-39. Where a population is barely holding its own, a small but steady drain may be sufficient to keep it from increasing.

During the last 2 or 3 years the bighorn population has held its own or possibly increased slightly. In view of the lack of forage in the Mount Everts area there is hardly room for more bighorn on that important winter range. There is a strong indication that the lambs are affected by some disease or parasite causing a severe cough, which, judging from the scarcity of lambs appearing on the winter range, may be eliminating some of them during the fall. The data obtained from the coyote droppings, from observations of the coyotes on the bighorn ranges, and from lamb counts at various times, indicate that coyote predation is at most an unimportant mortality factor, this in spite of a large population of coyotes on the bighorn ranges. 


\section{Chapter IX}

\section{OTHER LARGE MAMMALS IN RELATION TO COYO'TES}

\section{BISON}

Ruffalo (Bison bison bison) in the form of carrion furnish a source of B food which at times may be highly important to the coyote. In March 1938 a heavy mortality among the buffalo occurred in Pelican Meadows according to a report by Ranger Watson. On March 20 three of the buffalo observed in Pelican Meadows seemed to be within a few hours of death and a number of others showed signs of extreme weakness. Four carcasses, were found, and seven coyotes were seen in the vicinity of one of them. Tracks of a coyote were found at an old calf carcass near Fern Lake cabin. The dead buffalo in Pelican Meadows furnished the coyotes of that region with food for a number of days, and may have been instrumental in carrying through the winter some of these which otherwise might have perished.

On November ${ }^{-4}, 1937$, in the Horseshoe, remains of a yearling buffalo were found in a treacherous water hole located in a sedge-covered bog. The buffalo had no doubt drowned. Coyotes were feeding on the carcass and a day later a bear had pulled most of it out of the water.

It is unlikely that coyotes kill many buffalo calves. Some kills have been reported in the park but the reports which have come to my notice have lacked proof that coyotes killed the animals.

\section{MOOSE}

Remains of moose (Alces americanus shirasi) were found in one dropping. For several years the moose population in the park has been officially estimated at about 700. Moose are present in such numbers that in some of the favorite summering areas the willows have been heavily browsed. In winter the moose generally move to higher ground, away from the willow tracts and borders of lakes and streams. Scattered over the park, so that they are seldom seen in winter, they subsist largely on Douglas fir, and various shrubs available in the particular areas used.

Since moose can travel quite readily in deep snow if it is soft, and since they are primarily browsers, they are not affected by snow to the same 


\section{Fauna of the National Parks of the United States}

extent as are the elk. There is relatively little overlapping of moose and elk range in winter in Yellowstone National Park at the present time for few moose are found on the north side in winter. It may be true, of course, that more moose would be found in this area if it were not so badly overbrowsed.

Moose furnish coyote food mainly in the form of carrion. Near a deep water hole on Geode Creek, adjacent to another "bottomless" water hole in which several elk had been drowned, I found the carcass of an old cow moose on May 16, 1938.

It is possible that occasionally a calf is found by a coyote. On June 19, 1937, one was made available to coyotes through an accident. In the morning some fishermen found a calf moose in water so deep that it had to stand to keep its head above the surface. It was thought that the animal had fallen off a steep bank. The mother remained near her offspring, preventing the fishermen from rescuing it. By afternoon, the calf had drowned.

\section{DOMESTIC COW}

The five droppings containing domestic cow were gathered near the Game Ranch not far from one of the ranches still within the borders of the park. The source of this food would undoubtedly be carrion. Such has been found to be the case so generally in studies on areas adjacent to Yellowstone National Park that it appears to be a safe conclusion. However, in other parts of the country, young domestic calves have been reported killed by coyotes under certain circumstances.

\section{BLACK BEAR}

Remains of bear (Ursus americanus cinnamomum) found in 43 droppings all represented carrion occasionally made available by the shooting of dangerous campground and roadside bears. Most of the droppings were found in the vicinity of areas where dead bears were known to have been left.

\section{COYOTE}

Coyotes (Canis lestes) feed readily on coyote carcasses even when other food is available. Remains were found in 13 droppings.

\section{CARCASS FRAGMENTS IN COYOTE DIET}

Bone.-Fragments of large bones were found in 47 droppings. These bones may be consumed together with the meat of a carcass, or chewed from a skeleton long after the meat has been removed. Immediately after 


\section{Ecology of the Coyote in the Yellowstone}

an elk skeleton has been cleaned of flesh most of the ribs have only the tips chewed. The coyotes continue to visit the bones until often only a short stub of each rib, 2 or 3 inches long, remains. Processes of the vertebrae are also chewed off. Sometimes the ribs are chewed short in 2 or 3 days after feeding on the carcass has begun. Often weathered skeletons several years old are visited by coyotes, who stop to eat a little of the bone in passing. Old weathered bone is often eaten when food is plentiful so is not necessarily resorted to because of hunger.

On November 21, 1937, I followed a coyote's trail near Junction Butte and came to a spot where the coyote had chewed off vertebral processes of an old bull elk that had died during the previous winter. On January 13, 1938 , a coyote was seen chewing on some gray and weathered vertebrae of a fawn. On January 25, 1938, near Deckers Flat, part of an old elk skeleton had been eaten. On October 1, 1938, near Tower Falls two coyotes were frightened from some bones of an elk that had died the previous winter. The tips of several ribs had been freshly chewed.

Antlers.-On several occasions shed antlers of deer and elk were found which had been chewed by coyotes. Some of these antlers were freshly shed while others had been shed at least a year previously. Deer antlers that had been recently chewed by coyotes were found on January 26 and 30, and February 12, 13, and 16. One antler chewed on February 12 was seen again February 13, and it was noted that during the night coyotes had almost removed one of the tines. On February 16 an old elk antler was found which had been much reduced by coyotes. Deeply grooved tooth marks, probably made by the canines, were left on some of these antlers.

Hoofs. - Bits of hoofs of deer and elk were frequently found in the scats. Several instances were noted in the field in which the coyotes had gnawed on a hoof. On November 22, 1937, while examining a bull elk skeleton from which the flesh had been eaten a day or two previously I noted that one-half of a hoof had been consumed. On January 15 a coyote was seen to stop at some elk remains and chew away part of a hoof, and on January 26 a deer hoof was eaten. On February 10, 1938, part of a hoof of an old

ram was eaten although half of the meat of the carcass remained. On February 15 the hoof of a deer fawn was chewed. 


\section{Chapter X}

\section{SMALL MAMMALS IN RELATION TO GOYOTES}

\section{FIELD MOUSE}

$\mathrm{T}$ He FIELd mouse, Microtus sp., along with pocket gopher, is the staple food item in the coyote diet from April to November. During the winter months some field mice are eaten but they represent a minor item in the diet over most of the winter range, where other foods are more available. This was especially true in the winter of 1937-38 when the snow was crusted and there was much carrion. When snow conditions are favorable and mice abundant, the coyote can subsist quite well on mice even though a foot or more of snow covers the ground. A total of 3,044 or 33.9 percent of the 8,969 food items were field mice. They occurred in 2,155 droppings.

Accurate measurements of field mouse population could not be made, but from general observations it was apparent that the populations were high in the spring of 1937 when the study was begun, and remained high during the winter of 1937-38. There seemed to be, from general observa. tions, some slight reduction in the population by the beginning of 1938 . In Jackson Hole, immediately south of the park, great numbers of field mice were found dead during the winter, and they became relatively scarce by the summer of 1938.

During the spring, summer, and fall, coyotes spend much time in the meadows hunting mice and pocket gophers. This occupation seems to be successful on the last spring snow, for coyotes often hunted there when bare areas were available. To illustrate the mousing behavior a few descriptions from my notes are given.

On May 14, 1938, at Willow Park I watched from 9:45 a. m. until 11:30 a. m. two coyotes hunting over a broad expanse of snow which was more than a foot deep in places. Much of Willow Park was bare of snow but these coyotes confined their hunting to the snow field. A single coyote was hunting mice near me when I started watching, but in a few minutes a second coyote came out on the snow from the woods opposite. By 10 o'clock the near coyote which I had been watching had moved to the far side and the other had come quite near where I was hiding. Between 10 and 11:30 o'clock the latter was seen to capture and swallow 11 animals, all of which appeared to be field mice. For about 10 minutes of the period the coyote was out of my view so it may have captured 


\section{Ecology of the Coyote in the Yellowstone}

one or two others, and undoubtedly captured one or more mice during the 15 minutes it hunted, when I was watching the other coyote. In places the snow seemed to be crusted, for in pouncing, the coyotes occasionally were not able to break through the surface. Usually the mouse was not captured on the first pounce, but only after further quick strikes with the paws, three or four of which were sometimes made after the original major pounce. Sometimes the coyote would dig and paw for a minute or two before catching the mouse. The closer the coyote approaches to the point of capture, the more agitated it becomes, as is indicated by vigorous tail-wagging. Several times increased excitement on the part of the coyote was followed immediately by the capture. Once or twice a coyote was seen to cover 10 or 15 yards in four or five jumps before pouncing. Once, one of them ran about 15 yards and picked up a field mouse which was on the surface. In one place a second mouse was caught by further digging in the snow. The first pounce probably destroys the runways thus closing off ready avenues of escape and allows the coyote to pounce more accurately a second or third time. The coyote catching the 11 mice pounced without success about 30 times. These misses were in the snow, but in grassy areas misses were also frequent. The coyote was a male and seemed to be an adult. Once one of the coyotes stood at attention ready to spring for 5 minutes and then walked off without following through. Seven of the mice were caught in an area not more than 100 yards across. Both coyotes hunted throughout the period that I watched and were lost to view when they moved into the woods. At 4 o'clock a coyote was again hunting on the snow in the same locality.

As a coyote approaches a spot stealthily, it places each foot on the ground slowly and only gradually letting down its full weight. Sometimes it watches and listens with one forefoot poised in the air. Frequently a mouse is scented or heard while the coyote is trotting. It will then come to a stop, walk stealthily a few steps and poise for the spring. Standing with all four feet held slightly together, nose pointed at the spot, and ears cocked sharply, its body sways back a perceptible amount. Many times before actually leaping the coyote assumes a tense position only to relax and wait for the right moment. Generally the coyote springs high in the air and drops on its prey, hitting it with the front feet. The forelegs are held straight and braced to take the jar as it strikes. When the victim is caught beneath a mat of grass, the coyote must carefully paw aside the grass to get its prey.

Ranger Lee Coleman told me that in Pelican Meadows where the snow lies deep in winter he has frequently found coyotes hunting mice over areas which the buffalo have partly cleared in feeding. In these meadows where there are sometimes more than 200 buffalo wintering, this symbiotic relationship may be quite important at times to the few covotes staying there.

On Swan Lake Flat on April 14, 1938, coyotes had been traveling the sides of the road along the snow bank made by the rotary plow. The fresh snow showed that many mice had come out of the base of the drifts 


\section{Fauna of the National Parks of the United States}

onto the road. I saw a deer mouse which for several yards was unable to find a retreat in the snow. The coyotes had quickly learned of this mousing opportunity and had been there hunting.

\section{POCKET GOPHER}

Pocket gophers (Thomomys fuscus fuscus) made up 1,939 or 21.6 percent of the food items. Remains were found in 1,407 droppings. These rodents are active in winter under the snow and are occasionally taken at this time. Predators know the habits of the pocket gopher and have learned to wait for them to reappear above the ground when they are active at the open holes. Once a great grey owl at Yellowstone Lake was observed watching a spot for several minutes and then pouncing on a gopher when it appeared. In summer the coyotes readily capture them by waiting at the tunnel entrances where they are digging or coming out into the open to forage. From the results of the droppings analyses it appears that Thomomys are about as readily captured as field mice.

The coyote is probably one of the chief checks, due to predation, on the pocket gopher population. It is difficult to say how effective this control may be, or how beneficial in a wild region. In a mountain area, any harmful effects of moderately numerous pocket gophers may possibly be balanced by beneficial effects. Importance of the pocket gopher as a factor in erosion is not known. From general observations their activities in this respect seem to be beneficial as well as rather harmful. In some areas where sagebrush is an important deer and antelope winter food, and at the same time in a precarious condition from overbrowsing, coyote predation on pocket gophers may be highly valuable, for these rodents were found to cause considerable local though probably temporary damage to sagebrush during the winter months in places by cutting off branches and twigs. Some bushes were pruned down to within a few inches of the ground. Over most of the park, however, pruning of sagebrush by pocket gophers is probably not very harmful, and the animals are now absent or scarce over the heart of the critical antelope and deer winter ranges in the Gardiner region. Whether coyotes have had much to do with this local scarcity of gophers is not known but possibly the pocket gopher does not care especially for this Upper Sonoran habitat, particularly in its present overbrowsed condition.

In the coyote-pocket gopher relationship we find an apparent blending of harmful, beneficial, and neutral influences not readily segregated or measured. The rodent consumes a certain amount of forage, but also does service in soil building, furnishes an important food supply for raptores and 


\section{Ecology of the Coyote in the Tellowstone}

carnivores, and acts as a buffer species. On the other hand, the coyote makes inroads on this natural food supply but does not exhaust it, and among birds and mammals certainly is the greatest single factor in keeping the pocket gopher population within safe bounds.

The relative frequency with which pocket gopher and field mouse occurs in the droppings depends upon the locality and possibly on the time of year. In localities where pocket gopher habitat is scarce the percentage of gopher remains is low, but where pocket gopher and field mouse habitats are both present the pocket gopher may occur as frequently or more frequently in the droppings than the field mouse. In droppings gathered at Swan Lake where mice are specially plentiful in the marsh and heavy sedge around the lake and pocket gophers occur on the surrounding slopes, remains of 122 pocket gophers and 256 field mice were identified.

Between Swan Lake Flats and Norris near the road where there is but little pocket gopher habitat, the coyotes hunt mainly in the marsh along the creeks. Droppings gathered here contained remains of 82 pocket gophers and 352 field mice. Where good field mouse habitat predominates and pocket gophers are relatively scarce, gopher-mouse occurrence in the droppings is as follows: Gibbon Meadows and Elk Park, 39-362; Madison Junction, 3-53; Old Faithful, 17-222.

In other localities where pocket gopher habitat occurs extensively along with field mouse habitat, occurrence of the two animals in the droppings does not vary widely. Data from such localities follows:

\begin{tabular}{|c|c|c|}
\hline Locality & $\begin{array}{l}\text { Pocket } \\
\text { gopher }\end{array}$ & $\begin{array}{l}\text { Field } \\
\text { mouse }\end{array}$ \\
\hline 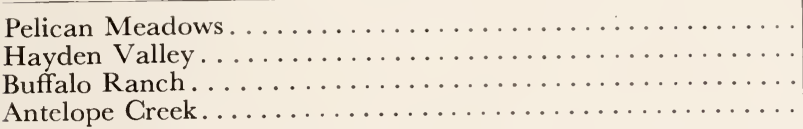 & $\begin{array}{l}622 \\
435 \\
222 \\
121\end{array}$ & $\begin{array}{r}780 \\
436 \\
251 \\
41\end{array}$ \\
\hline
\end{tabular}

Dúring July, August, September, and October the relative proportion of pocket gophers to field mice in the droppings is higher than earlier or later in the season. This high pocket gopher incidence probably coincides with a period of greater surface activity. The occurrence of gophers and field mice in the droppings from April to November is as follows:

\begin{tabular}{|c|c|c|c|c|c|}
\hline Month & $\begin{array}{l}\text { Pocket } \\
\text { gopher }\end{array}$ & $\begin{array}{l}\text { Field } \\
\text { mouse }\end{array}$ & Month & $\begin{array}{l}\text { Pocket } \\
\text { gopher }\end{array}$ & $\begin{array}{c}\text { Field } \\
\text { mouse }\end{array}$ \\
\hline $\begin{array}{l}\text { April . . . . . . . . . . } \\
\text { May . . . . . . . . . . . . . . . . . } \\
\text { June . . }\end{array}$ & $\begin{array}{r}17 \\
166 \\
280 \\
122\end{array}$ & $\begin{array}{r}237 \\
513 \\
474 \\
90\end{array}$ & $\begin{array}{l}\text { August . . . . . . . . . } \\
\text { September . . . . . . . . . . . } \\
\text { October . . . } \\
\text { November . . }\end{array}$ & $\begin{array}{r}296 \\
813 \\
86 \\
146\end{array}$ & $\begin{array}{r}172 \\
893 \\
67 \\
567\end{array}$ \\
\hline
\end{tabular}




\section{Fauna of the National Parks of the United States}

As mentioned before, only the majority of the droppings gathered in a month were actually deposited that month, but the dates as a whole are probably accurate enough to show the general trend. Availability of the prey species largely determines the extent to which it is eaten.

\section{SNOWSHOE HARE}

Remains of snowshoe hare (Lepus bairdi bairdi) were found in 305 droppings, making up 3.44 percent of the items. Many of the hares had been eaten in winter while in the white pelage. Where hares are abundant, coyotes are able to hunt them systematically and subsist on them alone. Coyotes spending the winter in the interior of the park probably feed extensively on them.

The snowshoe hare is widely distributed but not abundant over most of the park. In a few places it seemed to be locally abundant; this was true in an area near Old Faithful. The sweeping cycles of abundance and scarcity do not seem to occur with any regularity in Yellowstone although there is, of course, some variation in numbers from year to year. In an old diary kept by the soldiers at Sylvan Pass in 1903, 15 or 20 hares were frequently reported seen in a day so that hares at that time must have been quite plentiful. Ranger Elliott (1931) reported hares more abundant at Yellowstone Lake than in several preceding years.

\section{GOLDEN-MANTLED MARMOT}

Remains of marmot (Marmota flaviventris nosophora) occurred in 120 droppings. The marmot is a natural coyote food and in some localities makes up an important part of the coyote diet. On the high ranges occupied by bighorn in Teton National Forest, where marmots are plentiful, they form the main item in the coyote diet. In Yellowstone, although marmots are plentiful in rocky areas, over large areas separating the typical marmot habitats they are scarce.

\section{MUSKRAT}

Remains of muskrat (Ondatra zibethica osoyoosensis) were found in 98 droppings. Muskrats are not very numerous but are generally distributed along the water courses and ponds. During the fall and spring they are especially vulnerable to coyote attack when they wander out over the snow. Should a muskrat be discovered by a coyote when journeying on land, its chance of escape, are, of course, slight. Journeys of more than 100 yards on the ice were noted. Once a fresh coyote track was seen which crossed the track of a wandering muskrat but, fortunately for the latter, they had not met. Coyotes 


\section{Ecology of the Coyote in the Yellowstone}

have been found to investigate a network of tunnels along a stream but it seems probable that muskrats are generally captured accidentally, for it would hardly be profitable for the coyote to spend a great deal of time hunting them. Coyote pressure on muskrats does not appear to be great.

\section{GROUND SQUIRREL}

Remains of ground squirrel (Citellus armatus) were found in only 46 droppings. The low incidence of ground squirrel in the diet is probably due to scarcity of these rodents over most of the park. It is possible that the ground squirrel population has been held in check by the coyotes. Ground squirrels make their appearance in the spring before the snow disappears, burrowing through the snow to reach the surface. Some ground squirrels appearing on the snow had traveled as far as 40 yards to feed on vegetation; at such times the ground squirrels would be highly vulnerable to predation. Tracks in the snow were noted several times showing that coyotes had chased ground squirrels.

On May 14, 1937, I saw a ground squirrel climb to the top of a sagebrush and peer after a coyote which had passed close to its hole, and this watchfulness was observed on two other occasions. Where the ground squirrel is plentiful on the coyote range it probably is an important food item.

\section{WHITE-TAILED JACKRABBIT}

Remains of jackrabbit (Lepus townsendi campanius) were found in 37 droppings. This animal occurs only on the north side of the park and is not abundant, although tracks can always be found on its range. Since it does not occur in the interior of the park, there was no chance for it to be represented in about 3,500 of the droppings collected, so the incidence is lower than it would be if all the droppings were collected in jackrabbit habitat. George Bird Grinnell (Ludlow 1876), reporting on a trip made to the park in 1875, states: "Where all the coyotes and grey wolves have been killed or driven off, the hares exist in great numbers; but where the former are abundant the latter are seldom seen."

Because jackrabbits feed extensively on many plants, such as fringed sagebrush and various kinds of yellowbrush, which are important big game plants, the coyote's predation on jackrabbits tends to be beneficial from the standpoint of preservation of the over-utilized range.

\section{PORGUPINE}

Remains of porcupine (Erethizon e. epixanthum) were found in 35 droppings. Full-sized quills which became sharp on drying were frequently 


\section{Fauna of the National Parks of the United States}

found in the droppings. Wherever porcupine occur they tend to appear regularly in the coyote diet. O. J. Murie (1935) found porcupine remains in 78 of 714 droppings gathered in Teton National Forest just south of Yellowstone Park. The observations of several men are given, showing that the coyote can kill a porcupine and probably does so frequently. Porcupine quills were found under the hides of many of the coyotes shot at the time that coyote control was practiced in the park. Near the South Entrance on March 19, 1937, Ranger Verde Watson (Yellowstone Nature Notes, March 1938, p. 15-16) found a porcupine that had been killed by two coyotes. They had worried it while it traveled to the river, where it had escaped, only to be again attacked and killed when it came to shore about 200 yards downstream. Now that other predators are rare in Yellowstone National Park the coyote probably serves as a useful check on the species.

\section{DEER MOUSE}

Remains of deer mouse (Peromyscus maniculatus osgoodi) were found in only 34 droppings. Considering the abundance of this mouse in the park, one would expect to find more of their remains in the droppings. O. J. Murie in his Jackson Hole coyote studies also found its incidence in the diet to be low, only eight deer mice occurring in 714 droppings and 64 stomachs. In some fox studies on the George Reserve in Michigan (Adolph Murie, 1934) I found that the deer mouse likewise made up but a small item in the fox diet. The deer mouse, although active above ground at night, is not so easily secured as the field mouse. It scurries from cover to cover, while the field mouse often feeds and travels in runways where it is easily captured by the coyote. It furnishes food for other animals equipped to feed readily upon it. Santee and Granfield (1939, p. 3-9) for instance, in California found the saw whet owl, Cryptoglaux acadica feeding almost entirely on the deer mouse, Peromyscus sp.

\section{PINE SQUIRREL}

Pine squirrel (Sciurus hudsonicus ventorum) was found in 25 droppings. These squirrels are abundant in the pine woods, but as one would expect, it appears that they are captured only incidentally by the coyote.

\section{BEAVER}

Remains of beaver (Castor canadensis missouriensis) were found in 17 droppings. On June 29, 1937, along the upper reaches of the Gardiner River, the carcass of a beaver was found which had been eaten mainly by birds but had also been visited by a coyote. The beavers are generally distributed 


\section{Ecology of the Coyote in the Tellowestone}

over the park. Where colonies have eaten out their food supply there are many abandoned dams, and in some places meadows have replaced the beaver ponds. In some streams the older deserted dams and stumps and stubble of the beaver harvest are found near the mouth, and as one approaches the head of the stream the signs become more and more recent until one finally arrives at the occupied ponds. It appears that food supply is the real control of the beaver population. In some ponds whose shores have been denuded of most of their beaver food for several years, a few beaver continue to subsist. The fact that they are able to persist under unfavorable conditions existing at these denuded ponds also suggests that coyote pressure on them is not unduly severe. The beaver pond-beaver meadow cycles do not seem to have been interrupted in Yellowstone by a long continued abundance of coyotes.

\section{COTTONTAIL RABBIT}

Remains of cottontail rabbit (Sylvilagus nuttalli grangeri) were found in only eight droppings. The cottontail is absent from much of the park, and from the areas in which most of the coyote droppings were gathered. Only about 300 droppings were gathered in the district where cottontails are found. They are quite common along the Gardiner River below the mouth of Lava Creek, around Mammoth, and on the Gardiner and Game Ranch areas. Along the Yellowstone River a few tracks were noted as far up stream as Hellroaring Creek but this seems to be the limit of this Upper Sonoran form. It is interesting to find several Upper Sonoran species that have extended into the park along the Yellowstone River. Ranger Grimm said that many rabbits died around the elk trap at the Game Ranch during the winter of 1935-36, and that since that time they have not been nearly as abundant. For a stretch below the mouth of Lava Creek along the Gardiner River, rabbits were quite common. This area was also much frequented by coyotes attracted there by carrion as well as by the Mammoth dump. The rabbits were living in holes and in heavy tangles of brush. Near the Government Garden on February 6, 1938, a coyote was seen with a recently caught rabbit in his jaws. Between Mammoth and Gardiner two rabbits were found which had been killed by cars and were probably later found by coyotes, ravens, or magpies. The rabbit is present in fair numbers within its range and there is apparently no excessive predation on it by coyotes.

\section{MISCELLANEOUS SMALL MAMMALS}

The jumping mouse (Zapus princeps) was found in only seven droppings. Although several species of chipmunks (Eutamias sp.) are represented 


\section{Fauna of the National Parks of the United States}

in the park, and the animals are fairly common, their remains were found in only six droppings. Coyotes probably pick up chipmunks only as they chance to come upon them. These rodents are, no doubt, too alert and active to be profitably hunted.

As woodrats (Neotoma cinerea orolestes) usually live among the rocks they are not readily available to the coyote. 'Their remains were found in four droppings.

Remains of mink (Mustela vison energumenos) were found in three samples. It is my impression that, although widely distributed, mink are not abundant in the park.

Shrew remains (Sorex sp.) were found in two droppings. On September 4, 1937, at Gibbon Meadows a shrew carcass was picked up about 50 yards from where I saw a coyote pup. The shrew was fresh and still moist around the neck so it appeared that it had been caught and left uneaten by the coyote a few moments before I found it. O. J. Murie (1935) found no shrews in 714 droppings gathered in the mountains in the Jackson Hole region. This fact, together with the low incidence in the Yellowstone material, suggests that they are not relished. In many places where the coyotes hunt, shrews are active and available. In my study of foxes at the Edwin S. George Reserve near Pinckney, Mich., it was found that many shrews were captured and left uneaten. It is likely that this is also true of coyotes when food is abundant.

Remains of coney (Ochotona princeps ventorum) were found in but one dropping. This species is well protected from coyote attack by the rocks in which it lives.

Weasel remains (Mustela frenata) were found in only a single dropping. At Crevice Creek on February 17, 1938, signs indicated that the coyotes had been playing with a weasel carcass. The rear half was lying on the snow about 500 yards from the anterior portion. Apparently neither had been eaten.

It is likely that the remains of bat (Myotis sp.) found in one dropping represented carrion.

The one dropping noted containing house cat was found near Gardiner where cats occasionally stray into the park.

Flying squirrel (Glaucomys sabrinus bangsi) remains were found in one dropping. The species is not abundant, nor is it readily available to coyotes.

Remains of a very young marten (Martes caurina origenes) were found in one dropping. This may or may not have been carrion. Martens are too active to fall frequent prey to coyotes, although they occur in moderate numbers in the park. 


\section{Chapter XI}

\section{BIRDS IN RELATION TO COYOTES}

\section{DUGKS}

$\mathrm{D}$ URING the summer there are several thousand ducks in Yellowstone. In August 1938 more than 200 ducks were on the open waters of Swan Lake and many others may have been out of sight in the vegetation. In another instance I saw more than a thousand on a single lake. Some of the species included in the summer population are: mallard, Barrow's goldeneye, American merganser, gadwall, blue-winged teal, green-winged teal, and harlequin duck. During the spring and fall numerous other species also stop on park waters.

Many ducks winter on the open waters. A count made between January 14 and 20, 1939, resulted in the following: mallard, 316; goldeneye (American and Barrow's), 556; merganser, 73; bufflehead, 78; and green-winged teal, 10. In addition, 241 Canada geese and 106 trumpeter swans were counted, making a total of 1,725 waterfowl. A similar count made in the winter of 1938 yielded a total waterfowl count of 1,618. These counts are incomplete but are roughly comparable. They at least indicate that there are many ducks wintering in Yellowstone.

The majority of the 5,086 coyote droppings were collected in areas where ducks were plentiful during the nesting season and could be expected to furnish an appreciable amount of coyote food. Special effort was made to obtain representative collections in the vicinity of duck nesting localities.

Of the 5,086 coyote droppings collected duck remains were present in 82 , or 1.6 percent. The incidence of occurrence was about the same in the 2 years during which droppings were gathered. In addition to the foregoing 18 food items classified simply as "large bird" and 62 as "bird" may have included some duck remains, not recognizable as such. The remains of 11 of the ducks were recognized as those of mallard. Furthermore, the following feather remains, in spots where ducks had been eaten, were found along the Firehole, Yellowstone, Madison, and Pelican Rivers: 13 unidentified ducks, 6 mallards, 3 green-winged teals, 1 gadwall, 1 bufflehead, and 1 goldeneye. These remains were found along about 40 miles of river banks and lake shores. 


\section{Fauna of the National Parks of the United States}

Evidence of duck nest raiding was very meager. Eggshell fragments, possibly those of ducks, were present in 10 droppings and a single duckling was present.

Droppings containing duck feathers were sometimes grouped near feather remains in one spot, suggesting that a single duck was represented in several droppings. As an example, at one such pile of feathers were three fresh coyote droppings, all containing duck remains. The following is also suggestive: On December 17, 1937, on the bank of Flat Creek in Jackson Hole, I found the carcass of a female mallard which a coyote had investigated. Pin feathers on the wing showed that the duck had died in late summer during the moult. Only a little of the breast was eaten. The coyote had gnawed lightly at the dried carcass, then left it. Two or three feathers in the coyote's trail 10 feet away probably had dropped from his lips. Judging from other observations it is possible that subsequently, each time the animal passed that way, it nibbled at the bird enough to swallow a few feathers, thus leaving feather records in several droppings.

An unknown proportion of the duck remains would represent carrion. Near several of the better duck waters are telephone wires which the ducks probably fly into occasionally and thus lose their lives or become severely injured. As mentioned elsewhere, several dead grouse were found which had flown into the buffalo pasture fence and a telephone wire. A robin had been killed flying into the same fence, and one evening, in the dusk, one of two robins struck the single telephone wire and fell to the ground with a thud. Since even bats do not always avoid objects, such as nets, it seems probable that a swift flying flock of ducks might occasionally lose a member in this manner.

In the autumn, wounded or sick ducks apparently come into the park and are unable to leave, either dying or remaining on the waters in a flightless condition. Such ailing ducks would occasionally fail prey to coyotes or furnish a certain amount of carrion. Concerning wounded ducks, Assistant Chief Ranger Albert E. Elliott, (Yellowstone Nature Notes, January, 1937, p. 7) writes:

Since the lake and river (Yellowstone) have frozen over, it is possible to find among the waterfowl which are left here quite a number that have been wounded (outside the park) and are not able to continue on their southern flight. Many of these will fall easy prey to coyotes, otter, eagles, and other of their natural enemies during the course of the winter.

Kalmbach and Coburn (1937) found disability and mortality among ducks wintering in southern Idaho in 1937 and report that such mortality on wintering grounds is not unusual. Inspection of $2 \frac{1}{2}$ miles of banks of the Portneuf River near Pocatello disclosed 75 dead ducks, and a number of 


\section{Ecology of the Coyote in the Yellowstone}

dead ducks were found along several drainage ditches. These ducks were heavily parasitized and lead shot was present in some of the birds. In view of these findings it is not surprising that disabled birds are found in Yellowstone.

An interesting though probably a minor cause of duck carrion is mentioned by N. P. Langford (1870). He writes:

As we stood on the margin of this immense lake (Excelsior Geyser) a small flock of ducks came sailing down as if to alight; but as they skimmed the water (of a hot spring) a few inches above the surface, they seemed to scent danger, and with rapid flapping of their wings, all except one rose into the air. This one, in his descent, had gained too great an impetus to check his progress, and came down into the water, and his frantic efforts to rise were futile, and with one or two loud squawks of distress, which were responded to by his mates, who had escaped, he was a dead duck.

The extent of this kind of mortality is probably not great, and probably those scalded but still able to get away would be available to the coyotes. In the hot pools of Old Faithful I have seen duck and goose skeletons. Near a hot pool at Old Faithful in which lay the skeleton of a duck, Assistant Park Naturalist W. E. Kearns found a coyote dropping containing duck feathers; however, there was probably no connection in this case between the duck remains in the spring and the feathers in the dropping.

During the summer of 1937 I found the carcasses of three mallards and a merganser that had not been eaten, the carcass of a mallard that had been partially eaten by birds, and two complete skeletons of uneaten ducks. These seven carcasses, undiscovered by coyotes, suggests that there must be many others that they do find. During the fall the amount of duck carrion would probably be greater than during the summer because of the influx into the park of injured or sick ducks.

In the interpretation of field observations it should be kept in mind that other animals besides the coyote are potential predators on ducks. Mink and otter probably occasionally catch one, and the eagles, of both species, prey on ducks to some extent. I once saw what appeared to be a golden eagle in immature plumage sitting on a mallard not yet dead. At Old Faithful in April 1938 I found the wing of a bufflehead duck at the base of a telephone pole and a bird pellet containing duck feathers at the base of an adjoining pole. The duck may have been killed by a predator, or it may have flown into the wires and died from injuries. In the same region about a mile away another bird pellet was found containing duck feathers, and at Gibbon Meadows in the spring of 1937 two bird pellets contained duck feathers. I mention these other predators here to show that preying on ducks is distributed among a number of species, including the coyote. 


\section{Fauna of the National Parks of the United States}

During the winter of $1937-38$ from 40 to 50 mallards and about as many goldeneye ducks spent the winter on 3 or 4 miles of the Gardiner River where coyotes were concentrated. Frequently I followed the shores of the river during the winter in search of duck remains but found none. Coyotes were apparently not molesting these ducks. A few ducks winter on the Yellowstone River between Gardiner and Tower Falls but no indication of predation was found along this stretch of water.

Rangers report some duck predation by coyotes in winter but from all I can gather this is not serious. Coyote trails are frequently found along the open water but these animals would probably follow water courses in their travels if ducks were entirely absent, for streams are natural highways for many species. One such trail was reported to me and an informant conjectured that probably the coyotes were here persistently hunting the ducks in the stream. I investigated, picked up a dozen droppings along the beaten trail, and found that they all contained elk hair.

In late November 1938 I saw a pair of mallards on a bit of open water, not more than 7 or 8 yards in diameter, in an ice-covered lake near Blacktail Deer Creek. Once they flew off but returned to the water after making a wide circle. They were restless and apparently dissatisfied with the size of the opening. When a coyote came trotting toward them on his way to some carrion they flew away while he was still about 70 yards from them, thus indicating their alertness and feeling of insecurity.

I do not doubt that a coyote would seize a duck if he had a chance, but it appears that this opportunity occurs so seldom that both the birds and the coyotes usually ignore each other, especially when the birds have the advantage, as they generally do. O. J. Murie in his notes for January 25, 1939, in Jackson, Wyo., writes:

Up in the swamp today, below the old Peterson Place, two coyotes were feeding on the last remains of a dead elk. About 100 yards away or a little more, three trumpeter swans were feeding and preening contentedly, while in the stream nearby, probably 10 or 15 yards away, a duck was feeding.

Such observations are quite typical of the relationship existing between ducks and coyotes.

\section{CANADA GOOSE}

The Canada goose (Branta canadensis canadensis) is generally distributed over the park in all favorable habitats in summer, and in winter a number of them are found on the open waters, especially on the Madison, Firehole, and Yellowstone Rivers. When not feeding in the water the geese spend much time grazing on green vegetation on land, at times a mile or more 


\section{Ecology of the Coyote in the Yellowstone}

from the water. In late summer, quantities of grasshoppers were eaten at some of the meadows.

Although adult geese are unusually alert it does not seem unlikely that a goose is occasionally captured by coyotes. In winter some remains of geese that may have been killed by coyotes have been found by rangers along streams. However, from the information available, the total winter and summer predation on geese is not extensive. In the spring of 1937 I found remains of four geese along the Lamar, Firehole, and Madison Rivers only by covering long stretches of these streams.

There is always the possibility that some of the geese eaten by coyotes represent carrion. The winter keeper at Canyon said that a goose unable to fly had been seen two successive winters on the Yellowstone River. Such a goose is at a disadvantage and might sooner or later be picked up by a coyote. Rangers E. E. Peterson and Guy McCarty (Yellowstone Nature Notes, April 1930, p. 20) report an incident in which two geese crashed into the steel cable across the Yellowstone River one-half mile above Chittenden Bridge. One goose received a broken wing and the other was swept over the falls.

Goose remains were identified in only 12 droppings. As seven of these droppings were found near a dead goose along the Lamar River and in a hay stack only a short distance away, they apparently represented the same bird.

When a coyote feeds near a group of geese one or more of the birds generally keeps a close watch. Usually the coyote pays little or no attention to the geese even though it may be within 40 or 50 yards of them.

Geese in the park nest in various situations. Two nests were found on top of hay stacks at the Buffalo Ranch. In passing one of these a goose on the nest lowered its head and neck against the hay but at the same time kept a close watch of me. Many nests are built on hummocks and islands in the water and others on the mainland. There was not time to make a detailed survey of the extent of coyote predation on goose nests and young, but information indicates that many geese were being successfully raised in the park.

On July 11, 1937, on the Lamar River near the Buffalo Ranch where coyotes are plentiful five families of geese were seen and a few days earlier another family was recognized as different from the others because of the large size of the young. Other families noted in 1937: June 11, Oxbow Lake, (2); Floating Island Lake, (1); June 15, Madison River, (1). Nymph Lake, (2); June 16, Yellowstone River, (2); June 17, Buck Lake, (1); June 19, Pelican Creek, (1). The 16 families ranged in size from one to six, and 


\section{Fauna of the National Parks of the United States}

made a total of 49 young. There was no systematic effort to make a large count of geese. They were only tabulated as I happened to note them. Since geese can hide well on shore it is probable that some were overlooked in the territory covered. The three young at Floating Island Lake were seen there until September 30. Late in September the family was flying about but often returned to the home lake.

During the summer of 1938 I spent relatively little time in the park but noted several geese with young as follows: June 4, at a shallow pond near Trumpeter Lake, two families of two and four young; June 8, Floating Island Lake, one family of seven; July 12, on Nymph Lake, one family with one young and two with four in each; July 13, Oxbow Lake, a family with six young. On August 13 there were still seven young at Floating Island Lake and five were seen at Oxbow Lake.

The general abundance of geese and the prevalence of young indicates that geese are doing exceptionally well in Yellowstone. The few goose remains in the droppings show that these birds seldom fall prey to coyotes.

\section{TRUMPETER SWAN}

The relationship of coyotes to trumpeter swans (Cygnus buccinator) is of special importance because of the relatively small numbers of these swans still surviving. In the United States their breeding range is restricted to the Yellowstone National Park, Jackson Hole, and Red Rock Lakes regions. In Canada they are more widely distributed and less rare.

Status of swan in Yellowstone National Park.- The best information available on the status of the swan in Yellowstone National Park, taken from the 1937 and 1938 reports, is included in the following table:

\begin{tabular}{|c|c|c|c|c|c|c|c|}
\hline Year & Adults & Cygnets & Total & Year & Adults & Cygnets & Total \\
\hline $\begin{array}{l}1931 \ldots \\
1934 \ldots \\
1935 \ldots\end{array}$ & $\begin{array}{l}27 \\
16 \\
16\end{array}$ & $\begin{array}{l}11 \\
17 \\
11\end{array}$ & $\begin{array}{l}38 \\
33 \\
27\end{array}$ & $\begin{array}{l}1936 \ldots \\
1937 \ldots \\
1938 \ldots\end{array}$ & $\begin{array}{l}38 \\
40 \\
40\end{array}$ & $\begin{array}{r}12 \\
29 \\
4\end{array}$ & $\begin{array}{l}50 \\
69 \\
44\end{array}$ \\
\hline
\end{tabular}

Recent counts have been more thorough than the earlier ones, but even these last census figures may be incomplete.

In 1937, 40 adult Yellowstone swans produced 29 cygnets, while at Red Rock Lakes 38 adult swans produced 51 cygnets. This apparently lower productivity in Yellowstone is perhaps due to the presence of a larger number of nonbreeding birds in the park, birds probably too young to 


\section{Ecology of the Coyote in the Yellowstone}

breed, or unmated for some other reason; also the Red Rock Lakes Refuge contains a larger area of suitable nesting habitat than does the park.

The swans begin nesting as soon as the ice goes out in late April and early May. Hatched in June, between 30 and 35 days after the eggs are laid, the cygnets usually do not begin to fly until late September.

In 1937 there were 7 pairs of swans which produced 29 cygnets. So far as known all but one cygnet of those that hatched survived through the summer.

The small increase in 1938 was due mainly to the small number of swans nesting and to small broods hatched. Three adult females found dead in early spring were probably potential breeding birds. Oberhansley and Barrows in their 1938 Yellowstone trumpeter swan studies (submitted in 1939) record 12 eggs that failed to hatch due to sterility, human disturbance, and unknown causes. The four cygnets surviving when the count was made in August were produced by four pairs. A fifth pair abandoned its nest apparently due to human intrusion.

At Beach Springs two unhatched eggs were found in the nest after the swans had left. At Swan Lake four of the six eggs laid failed to hatch. The eggs at Swan Lake remained in the nest for some time after the birds had left before they were collected and during this time, a period of 8 days, had not been molested.

At some of the lakes where swans have been raised, coyotes are concentrated. At Trumpeter Lake where seven cygnets were raised in 1936 and again in 1937, coyotes and coyote signs were frequently noted at the lake. Nineteen of thirty coyote droppings found at the lake contained only grasshoppers, and the others, except for one, contained elk, pocket gopher, and field mouse. The only evidence of waterfowl predation consisted of some remnants of a green-winged teal found on the bank and in one dropping. The swans here spent considerable time resting on the banks and occasionally walked with their brood a couple of hundred yards to an adjoining lake.

Usually the nests are located on islands in the water but occasionally they are on the shore. In 1937 the nest at Beach Springs and the one at Geode Lake were on shore. In the vicinity of these lakes coyotes are common. Since the swan on a nest is very conspicuous, the coyotes frequently must have seen these swans on the nests. While one bird is on the nest the mate is much of the time nearby, often only a few feet away. It is possible that two swans are a little more than a coyote cares to tackle, especially when mice and pocket gophers are available in abundance for food.

The swan may also enjoy some measure of safety from the watchfulness of its associates. At Trumpeter Lake, and some of the other lakes, many 


\section{Fauna of the National Parks of the United States}

blackbirds, mainly red-winged and yellow-headed, nest in some numbers. The presence of many of these birds on the margins of the lakes makes it unlikely that a coyote could remain long in the vicinity without attracting their attention and their alarm notes would warn the swans. Other birds, such as ducks and grebes would also help keep the lake inhabitants informed of the approach of a coyote. The swans, when feeding, are often followed by grebes, ducks, and geese who benefit from the stirring up the swan gives the under-water vegetation.

The swans themselves are alert but do not show much fear of other animals. On May 28, 1938, Frank Oberhansley and I watched two adult swans at Geode Lake from 4:05 p.m. to 5 p. m. They were idling about 4 feet apart on the low shore about 7 feet from the water. Their necks rested gracefully over their backs and their bills were pushed under the feathers inside the wings. The eyes of one of the birds seemed completely covered by the feathers most of the time, but the other had its eyes exposed. Once or twice during the first half hour that we watched they stretched their necks to look around but for more than 10 minutes at a time they seemed to sleep soundly. At 4:45 the swan whose eyes showed stretched its neck upward and a moment later the other also lifted its head into the air. They both looked inland; neither stood up. Presently a black bear passed below us about 25 feet from the swans. The bear did not pay any attention to the birds; it may not have seen them. While the bear was passing, the swans commenced to preen themselves and presently tucked their heads away for another nap. Two geese grazed on grass near them, always alert, and surely useful in announcing the approach of strangers.

On June 5 Oberhansley saw the two swans at Geode Lake resting on the shore where we had seen them on May 28. While he watched, a coyote passed near them, where we had seen the bear pass. The swans paid very little attention to the coyote, who in turn paid little attention to them. In trotting past it barely glanced in their direction.

In the fall of 1938 the Bureau of Biological Survey transported four swan cygnets from the Red Rock Lakes Migratory Waterfowl Refuge to some warm springs on the Elk Refuge in Jackson Hole. One of the birds disappeared soon after being released and no further trace of it was found. It may have flown away. The other three swans survived the winter even though it appeared in March that food in the water was becoming scarce. It is interesting to find these young birds, transported to a new environment, surviving in spite of the fact that coyotes were common. Coyotes were frequently seen in the vicinity of the area occupied by the birds. 


\section{Ecology of the Coyote in the Yellowstone}

A number of observations indicate that factors not at all related to predation tend to lower the swan population. In the spring of 1926 a dead mature swan (manuscript of Trumpeter Swan Report, Yellowstone National Park, Summer 1936) was found at Swan Lake, but the cause of death was not determined. The carcass was intact, so the bird seemed to have died from disease. Another dead swan was found on Daly Lake, between Livingston and Gardiner, early in the spring. The cause of death was unknown.

During the winter of 1935-36 Ranger Frank Anderson saw a dead swan floating down the Yellowstone River. A few years ago, O. J. Murie found two dead swans in a pond near Moran, Wyo., in early spring, which had died of disease or starvation.

During the spring of 1938 three dead swans were found in Yellowstone Park. All were adult females, probably birds which had been regular breeders in the park. The circumstances surrounding the deaths of these swans are as follows:

On April 12, Tom Phillips, a workman at the Buffalo Ranch, found two coyotes feeding on an adult swan on Slough Creek. Part of the back had been eaten and the neck was severed. The bird seemed to be in fair condition. It weighed $18 \frac{1}{2}$ pounds, and I estimated that $1 \frac{1}{2}$ pounds had been eaten. The intestines, proventriculus, and gizzard were empty and only a small quantity of sand was found in the latter. It was thought by Mr. Phillips that this swan was killed by coyotes, but considering the lack of food in the digestive tract it is more likely that the bird was not in normal condition and may have died before the coyotes found it. Archie Hull, in charge of Red Rock Lakes Migratory Waterfowl Refuge, told me that he had lost several swans from lead poisoning, caused by lead shot in waters frequented by duck hunters, and that he had found birds dying from this cause before losing their fat. Although no shot was present in the gizzard of the swan under discussion, there have been cases in which all the lead had been absorbed before death ensued.

On May 5 Ranger Walter Gammill found a dead swan on the shore of a shallow pond a few hundred yards east of Trumpeter Lake. I had seen the swan on this pond on April 25 and 28 and again on May 1 when it was resting on the shore 5 or 10 yards from the water. The shore of the pond where the swan was found is low and level, offering no cover for a stalking coyote. The head and one leg was missing and a little of one breast had been eaten. This was an adult female. The proventriculus was empty and the gizzard contained only about a level teaspoonful of grit. The intestines were also almost empty. The bird was so emaciated that there was no fat on the skin. The bird had unquestionably been sick. 


\section{Fauna of the National Parks of the United States}

On May 10 the linemen in the park reported that a dead swan was lying in Trumpeter Lake. Assistant Park Naturalist Oberhansley retrieved the swan and when we examined it we found no physical injury except a small festered spot on the back. This swan was also emaciated, weighing only 14 pounds, 14 ounces. The proventriculus was swollen and congested with green food. A number of much worn lead shot were found in the gizzard. The condition of the proventriculus and the presence of lead shot indicates that the bird, an adult female, died from lead poisoning.

On April 28 and May 1, 1938, a pair of swans were seen building a nest on Trumpeter Lake where the nest had been located the previous year. A mound of dead reeds was built about a foot above the water. After May 1, although the swans remained at the lake during the summer, no further nest building was noted. Shillinger and Cottam, (1937, p. 400) suggest that lead poisoning might upset the breeding activities of waterfowl. They write:

Even though a sublethal dose of lead is taken, experimental evidence indicates that the poison so upsets the normal physiological processes that interference with reproduction may result. It is well known that lead acts as an abortifacient in mammalian females and there is evidence that leads us to believe that it may induce sterility in birds.

There is a possibility, in view of the death of at least one swan and possibly two others from lead poisoning, in Yellowstone, that a sublethal dose of lead may also have interfered with the breeding of the pair at Trumpeter Lake.

The present status of the trumpeter swan is being given much attention. The 1937 census in the Yellowstone and Red Rock Lakes areas revealed 168 birds, and in 1938 there were 151. How many additional birds this region will support is unknown but it is not unlikely that the swan population is approaching the saturation point in this restricted area. Two limiting controls inherent in the region may be lack of nesting sites and a shortage of winter food. The nesting waters used by swans must have suitable nesting sites and also an adequate proper food supply. No study has been made of the wintering areas so far as I know, but it would seem that in the wintering waters there is a definite limit to the swan food supply. These same waters are occupied by numerous ducks and geese in winter, probably congregating there to the carrying capacity of available food supply.

J. A. Munro, Chief Federal Migratory Bird Officer for British Columbia, reports (Pough, 1939) on the winter food of the estimated 500 trumpeter swans in British Columbia: 


\section{Ecology of the Coyote in the Yellowstone}

The number of cygnets usually equals or exceeds the number of adults and from this it can be inferred that the summer loss through natural enemies is not large. Nevertheless there is, periodically, a heavy loss from starvation brought about by adverse weather conditions.

Probably the most serious direct mortality factor affecting the swans today is lead poisoning, to which these birds are very susceptible. Some of the victims have been found but no doubt many others have not been observed. Lead poisoning may operate not only in reducing the swans on the present range but also to prevent a spread into other areas.

Munro is quoted as follows concerning losses from lead poisoning:

At that time (1918) definite information was available regarding the wintering ground of one band which at its maximum contained 22 birds. The area involved was established as a Federal Bird Sanctuary with a warden service which is still maintained. Subsequently the greater part of this particular band died from lead poisoning; the number returning grew smaller each year and the flock finally disappeared.

These birds were probably so unfortunate as to spend part of their time on lakes whose bottoms contained much lead shot.

Another factor detrimental to the spread of swans is the accidental shooting of the birds when they get out into unprotected waters.

It was rather unexpected to find that the coyote in Yellowstone exerts no appreciable pressure on the trumpeter swan population. However the long necks of the swans give them an advantage in seeing any intruders. Furthermore, the swan is no doubt an adversary to be respected, for it is known that a swan can administer a powerful blow with its wings. At any rate, whatever may be the deterrents, the coyotes can find plenty of food during the summer without taking risks of being bruised. The data available at the present time indicate that the coyote does not represent an important mortality factor for the trumpeter swan.

In Yellowstone National Park and in all nesting areas precautions should be taken to prevent the birds from being molested during the summer season when the birds are nesting and raising their young. Roads, trails, fishermen, and other disturbing factors should not be permitted where swans are nesting and raising their families. Disturbance, at least in one known case, when the eggs had been laid, resulted in failure of eggs to hatch.

To insure the survival of the trumpeter swan in the United States a wider distribution should be encouraged. A step in this direction was taken by the Biological Survey when they moved four young swans into southern Jackson Hole, where three of them remained and wintered successfully. Probably more extended efforts of this kind would be desirable. 


\section{Fauna of the National Parks of the United States RICHARDSON GROUSE}

Remains of Richardson grouse (Dendragapus obscurus richardsoni) were found in five droppings; grouse, either Richardson or ruffed grouse, in five droppings. One of the grouse was a chick.

The blue grouse population seems to fluctuate very little in the Yellowstone region. This grouse is not abundant, but still is frequently found, especially on ridges and high slopes. It is commonly found at lower elevations in summer, but generally moves to higher elevations in winter. C. H. Merriam (Hayden, 1873), who made a trip in 1872 through Yellowstone and Jackson Hole, states: "The species was not abundant, being met with chiefly in the Teton Mountains."

During the middle of May 1937 a number of males assembled each evening on a sagebrush slope near Antelope Creek to strut and hoot. On May 18 I saw seven or eight males assembled and heard others close by. A fresh coyote dropping picked up on the area contained the foot of a blue grouse. There were four other fresh coyote droppings on the road nearby containing mainly elk hair. The assemblage of droppings made it appear that the coyotes had been attracted to prey on the grouse. On May 23 a ranger informed me that he and another ranger had found, in the fenced buffalo pasture below the place where the grouse were strutting, a blue grouse with the head eaten off and in another spot a mass of feathers. This seemed to indicate that the coyotes were getting several grouse. It occurred to me that these birds may have been found along the buffalo pasture fence after being killed by flying into it, so I walked along the entire fence. I found the body of the grouse mentioned above, but on searching found its head 7 feet on the other side of the fence. It had been severed when the grouse hit the fence. Another grouse had suffered a deep cut at the base of the skull where it had struck the wire. Remains of three blue grouse and four ruffed grouse were found along the fence, five of the kills being recent, and all had been eaten except two ruffed grouse. Obviously all of these were carrion, resulting from the presence of the wire fence. Two of the blue grouse remains were about 200 yards directly below the spot where the grouse had assembled each evening and where I had found grouse remains in a coyote dropping. Since these blue grouse in the buffalo pasture had been eaten recently, there was some probability that they were the source of the grouse remains in the dropping found in the road. Nevertheless, it still seemed that the drumming grouse must have attracted the coyotes to the spot, because of the number of fresh droppings there. However, the true explanation of the frequenting of the area by coyotes came to me as I climbed the slope to the strutting area. Upon 


\section{Ecology of the Coyote in the Tellowstone}

examining a spot about 75 yards below the grouse rendezvous, from which a raven was flushed, I found several neck vertebrae of an elk and some bloody elk hair. Apparently an elk carcass rather than the blue grouse had been the attraction. The incident is here related to show how easy it is to draw incorrect conclusions from field observations.

On June 10 near Trumpeter Lake some blue grouse feathers were found on a dirt mound at the entrance of a burrow. Upon examining the vicinity, the main mass of feathers was found 5 yards from a spot below some telephone wires. This grouse probably had met death by flying into them.

On November 6, 1937, I located remains of a blue grouse which had recently flown into the buffalo pasture fence and on May 27, 1938, remains of another were found along the fence. It is likely that grouse, because of their precipitous rapid flight, are killed more frequently by flying into wires and other objects than are other birds.

No evidence was secured to indicate that coyotes were preying extensively on this species.

\section{RUFFED GROUSE}

Ruffed grouse (Bonasa umbellus umbelloides) were identified in two droppings. In addition, the contents of any of five droppings which were identified as "grouse," may have belonged to this species. It is my impression that the ruffed grouse is slightly more plentiful in Yellowstone than is the blue grouse. The population seems to remain rather stable, and marked cycles of abundance and scarcity apparently do not occur regularly. C. H. Merriam (1873) in 1872 found that the ruffed grouse "was not an abundant species though it was found throughout the pine forests from Teton Canyon to the Yellowstone." This agrees with my observations during the past 10 vears in which I have been familiar with the Yellowstone-Jackson Hole area. Coyote depredations on ruffed grouse do not appear to be serious.

\section{OTHER BIRD REMAINS}

Remains which could be classified only as "bird" were found in 62 droppings. These included 55 "small birds," 18 "large birds," 5 immature sparrows, 1 sparrow, 2 Steller's (black-headed) jays, 2 warblers, 1 spotted sandpiper, 1 short-eared owl, 2 grebes, 10 large bird eggs, 7 small bird eggs, 3 domestic chickens (refuse), and 13 chicken egg shells (refuse). The domestic chicken and chicken egg shell were secured from garbage.

The jay was probably captured at a carcass. The grebe, eaten in the fall, probably was carrion since these birds would not otherwise be available to coyotes. At that time, otters in Yellowstone Lake were feeding consider- 


\section{Fauna of the National Parks of the United States}

ably on grebes which they no doubt can capture in the water. The coyote may possibly have eaten a grebe killed by an otter.

Potential bird carrion aside from duck remains was represented by carcasses of two robins, one hermit thrush, and a magpie, whose carcasses were found intact, and an adult marsh hawk unable to fly. On September 22, 1938, a long-billed dowitcher was picked up at Yellowstone Lake with a wounded wing. Feather remains of two red-tailed hawks, one short-eared owl, one meadow lark, one bluebird, one magpie, and one Steller's jay, were noted, besides those of ducks, grouse, and other kinds mentioned elsewhere.

There is always some question as to how near a coyote must approach a bird on a nest before it scents the nest. On two occasions I found unmolested nests of the white-crowned sparrow about a foot above the ground in the brush bordering the trail over which coyotes were traveling regularly. On June 14 I found the nest of a spotted sandpiper 15 feet from the Lamar River. The bird tried to entice me away by acting wounded. Seven feet from the nest were fresh tracks of a coyote which had passed without noticing it. Four nests with eggs and two pairs with young were noted in June 1937. All of these were found along the streams much frequented by coyotes. The spotted sandpiper is common in the park.

On several occasions, coyotes were observed jumping after bluebirds and sparrows, but this apparently was done mainly in play. At times they may be successful in catching the birds.

At carrion it seems that the magpies would be vulnerable to coyote attack, for frequently upward of a dozen magpies were seen hopping over a dead elk or deer on which coyotes were feeding, completely ignored by the latter. Some have been seen feeding less than 2 feet away from the coyote's head. At times the coyotes chase the birds, but it seems this is done mainly to drive them away and not to catch them. There seems to be a sort of instinctive neutrality between coyotes and magpies (also magpies and hawks) at carrion. However, the magpies are always alert at a carcass and ready to avoid being seized. The coyote may have found by experience that it does not pay to try to catch these birds.

O. J. Murie (1935, p. 19) found that coyotes had frequently visited the base of a high cliff on which a colony of cliff swallows were nesting. On July 22, 1937, in Hayden Valley a young dead cliff swallow was found beneath a cluster of their nests.

The number of all bird items including ducks, geese, and grouse, and the egg remains, occurring in 5,086 scats is 273 or about 5 percent. Birds are usually taken accidentally. 


\section{Chapter XII}

\section{MISCELLANEOUS ITEMS OF DIET}

\section{INSECTS}

CRASSHOPPERS AND CRICKETS: A total of 711 coyote droppings con$\checkmark$ tained grasshoppers, and 123 Mormon crickets. Very often droppings held both forms. These insects are eaten from the time they become available in the summer until November when the cold weather has made them inactive. Many of the droppings were composed of a high percentage of grasshoppers and crickets, very often 100 percent. Even in November fresh droppings had more than 90 percent grasshopper remains. Many contained remains of from 75 to 100 grasshoppers.

On September 25, 1937, I watched three coyotes hunting mice and grasshoppers in the meadows along the Lamar River. Sluggish with cold the insects were not moving. It seemed that the coyotes were finding them by scent. One of the coyotes hunted them for an hour, moving slowly over an area 150 yards across, turning a step or two aside one way or the other to pick up a grasshopper. Each one was given three or four vigorous chews, jaws opening unnecessarily wide, it seemed, for such a tiny morsel. While I watched, an antelope buck came up to me, gave an alarm call, and dashed away, whereupon the coyote near me ran several yards, looking around for danger as he went, but almost immediately turned back to the grasshopper hunting. The latest date on which I watched a coyote hunt grasshoppers was November 6. At this time all grasshoppers were dormant, of course, but the coyote seemed to find many of them.

A coyote I watched hunting grasshoppers at Gibbon Meadows on September 28 had to move quickly to make each catch, for the bright sunshine had brought a return of summer activity to the insects. Sometimes the grasshoppers were caught with the paw, at other times it seemed that they were seized with the jaws. Some were retaken after they had once escaped.

On one occasion 25 grasshoppers were caught in 4 minutes, but others were captured before and after this period.

Grasshoppers and crickets are an important and highly palatable food, or they are eaten in large quantities at times when much other food is 


\section{Fauna of the National Parks of the Lnited States}

available. The lower incidence of crickets in the diet is probably due to more restricted distribution than that of the grasshoppers.

June beetles.-Remains which appeared to be some form of the June beetle were found in 14 droppings. A few of the droppings contained as many as a dozen.

Hibernating flies.-Ranger Gammill told me that he and Ranger Coleman near the Cooke City Ranger Station had observed a coyote track turn to one side and lead over to the bank of a stream. Here they found that the coyote had been eating flies which were hibernating under the bark of a tree branch and on the under side of a rock.

\section{SNAKES, FISH, AND SNAILS}

Snakes are not very abundant in the park, but the remains of garter snakes were found in nine droppings.

Fish remains were found in 12 droppings, in several of which only the bones of the head were present. This would indicate that the coyote had found the spot where a fisherman had cleaned his catch. The fish in the diet is no doubt mainly carrion.

Remains of snail shells were found in four droppings. One summer in Jackson Hole O. J. Murie and I found a concentration of snails in the trail and a few feet away two coyote droppings containing many remains of them. They seem to be relished when they can be found.

\section{VEGETABLE MATTER}

Grass.-Eighty-eight droppings contained grass, usually consisting of broad blades, some of which appeared to be a coarse sedge. Many droppings consisted entirely of grass, while others contained lesser amounts. It makes up a definite part of the regular diet.

Pine nuts. - The nuts of Rocky Mountain white pine (Pinus albicaulis) and limber pine ( $P$. flexilis) were found in 51 droppings. Often almost the entire dropping was composed of pine nuts. Most of these were, no doubt, eaten in winter, even though the droppings containing them were gathered in early spring and summer. However, two fresh droppings containing pine nuts were found in early spring. O. J. Murie (1935, p. 22) writes: "Herb Whiteman, successful trapper in northern Jackson Hole, stated that in winter he has seen coyotes far back in the mountains digging down through rather deep snow for these nuts."

Fruit.-Berries are not abundant in Yellowstone National Park, which accounts for the scarcity of this item in the diet. Where fruit is available, it is often eaten in large quantities. Some of the droppings con- 


\section{Ecology of the Coyote in the Tellowstone}

tained large amounts of rose seed, and a few taken close to an apple orchard near the Game Ranch consisted almost entirely of apples. In 1938, 16 of one batch of about 100 droppings collected in Pelican Meadows contained strawberries. A number of fruits, such as serviceberry, mountain ash, and sarsaparilla, are much relished by coyotes in other areas.

Mushrooms.-Remnants were found in four droppings. This item disintegrates considerably during digestion so that its presence is probably often not recognized.

Dandelion roots.- On November 18, 1938, a coyote was seen in a plowed field near the Buffalo Ranch, feeding off the ground in various places and vigorously chewing the material it was eating. I examined the spot and found that it had been feeding on the fleshy roots of six or seven dandelions turned up and exposed by the plow.

\section{OTHER ITEMS}

Forty-eight droppings, found mainly near the Buffalo Ranch in the spring of 1937, contained nearly 100 percent horse manure. I believe most of it had been eaten during the winter. Food was scarce so that the coyotes in this region probably ate more of this material than ordinarily. O. J. Murie kept a tame coyote in Jackson, which, even when well fed, would often consume horse manure, so that apparently this material may be eaten by choice even when other foods are available.

Many analyses showed that coyotes had frequented garbage piles and camp grounds to feed on refuse. Even in midsummer when food is plentiful I have noted that the animals had eaten large rags and canvas gloves and, at a time when carrion was plentiful, part of the leather of a cast-off boot. This indicates that the presence of items of little or no food value do not necessarily indicate that the animal is starving. The botfly larvae found in seven droppings were probably attached to ingested mice or gophers. 


\section{Chapter XIII}

\section{GONGLUSIONS}

T EARLIER DAYs of conservation effort on a new continent we were handicapped by lack of precise knowledge, and, in order to meet new problems brought about by the invasion of man's interests into original wildlife habitats, direct methods were necessary and often there was no time to discover ecological facts, at that time considered obscure, or to develop preventive methods. Consequently a decided viewpoint on the question of predation was developed and, with modification, it has persisted.

We often deplore an apparent lack of foresight in earlier viewpoints and methods of handling our wildlife resources, but we need to consider the fact that each succeeding generation has greater facilities and opportunities.

Since the advent of the modern conception of wildlife management a new attitude toward the question of predation is growing. One of its precepts is that control of potentially harmful or suspected species of birds and mammals should await precise data based on research.

The results of the present study are, of course, not complete from the ecological standpoint. At least one or two more years would have been a welcome addition to the program in order to cover more annual variables. However, it is felt that the information obtained is sufficiently significant for present purposes. It is hoped that studies may be continued, as other duties permit, and that the coyote situation may be kept under constant surveillance.

Analysis of more than 5,000 coyote droppings from within Yellowstone National Park, containing nearly 9,000 individual items, reveals that, during spring, summer, and fall, rodents constitute by far the most important part of coyote diet, the majority of these being field mice and pocket gophers. The percentage of birds taken is relatively small and there is much evidence to show that many of the birds were obtained in the form of carrion. As a matter of fact the percentage of insects, particularly grasshoppers and crickets, computed on the basis of occurrence, is more than double the percentage of birds in the diet. Considering these items, together with a long list of miscellaneous species and materials, we must conclude that the role of the coyote in the fauna is not a harmful one during these seasons of the year. 


\section{Ecology of the Coyote in the Fellowstone}

In winter the examination of droppings was supplemented with intensive field observations and it became clear that the big game herds furnish most of the coyote's food. This is chiefly in the form of carrion, and, particularly in the case of deer, of weakened animals fated to succumb before spring.

In some categories it was found difficult to distinguish the proportion of carrion, as in the case of newborn elk calves, although it was definitely determined that some such carrion is available.

Special emphasis was given to the task of determining the effect of coyote pressure on prey species. The facts show that in the case of elk this is negligible, and that no appreciable inroads on the populations of deer, antelope, and bighorn are taking place.

On the other hand it became clear that the big game species are seriously handicapped by a poor, crowded range. Several big game species are competing with the bighorn and this situation requires continued attention.

The problem of the big game species in Yellowstone is not one of predation, but of inadequate winter range, a problem shared by many districts throughout the Western States. To remedy the plight of some of these animals it is recommended that additional winter range be provided for antelope in the Yellowstone Valley north of Yellowstone National Park. This would not be an addition to the park, but part of Absaroka National Forest. Antelope need the range if they are to continue in satisfactory numbers. Providing adequate winter range down the Yellowstone for this species and some of the elk would tend to relieve the competition with the bighorn.

Special attention was given to the status of the trumpeter swan, since it is the policy of the National Park Service to safeguard threatened species. The coyote has been suspected as a destructive factor limiting the increase of the species. However, no evidence was found that the coyote preys upon the swans. On the other hand, positive evidence points to lead poisoning and starvation, among other possible factors. It is probable that food limitations in winter may be potent in preventing greater increase of the trumpeter swans.

It has been feared that Yellowstone National Park serves as a reservoir from which coyotes may spread and populate distant areas where they are not wanted. There are few precise data in support of this, but, on the other hand, observations indicate that coyotes would rarely travel any great distance and that the majority remain with the game herds in the vicinity of the park boundaries. Forested areas adjacent to the park already carry a permanent coyote population. Trappers along the north side of Yellowstone National Park welcome the appearance of coyotes outside of the boundaries. 


\section{Fauna of the National Parks of the United States}

Apparently the Yellowstone coyote population does not increase indefinitely. Facts enumerated above show that the population level is kept down by disease, possibly in some cases by starvation, and that this species is subject to natural controls.

In the present study every effort was made to study the coyote in its interactions with all elements of the fauna and its relation to human interests. In consideration of these findings and the absence of facts to show that the coyote is an undesirable element of the wildlife in Yellowstone, it is concluded that artificial control is not advisable under present conditions.

The National Park Service is charged with the responsibility of preserving designated areas, selected samples of primitive America, in their natural condition for the enjoyment and study of present and future Americans. In line with this high purpose the flora and fauna should be subjected to a minimum of disturbance. The natural interactions of the members of the fauna and flora and the environment have a place in such a scheme and serve to furnish significance and greater interest in the animal life. Study of early records shows that, with a few exceptions, the general faunal pattern of the Yellowstone has persisted to the present time. A desirable member of the assembly of animals, the coyote contributes to the interest and variety of this fauna.

\section{BIBLIOGRAPHY}

Batley, Vernon

1926. A biological survey of North Dakota. North American Fauna, No. 49, pp. $1-416$.

BAILEy, VERNON

1930. Animal life of Yellowstone National Park. Thomas-Baltimore.

Cope, E. D.

1885. The present condition of the Yellowstone National Park. American Naturalist, Vol. 19, November 1885, pp. 1037-1040.

Hamlett, G. W. D.

1938. The reproductive cycle of the coyote. United States Department of Agriculture. Technical Bulletin No. 616, pp. 1-11.

HAYDEN, F. V.

1872. Preliminary Report of the United States Geological Survey of Montana and Portions of Adjacent Territories. 5th annual report. Washington. Government Printing Office.

1873: Sixth Annual Report of the United States Geological Survey of the Territories Embracing Portions of Montana, Idaho, Wyoming, and Utah. Washington. Government Printing Office.

JONES, W. A.

1875. Reconnaissance of Northwestern Wyoming, including the Yellowstone National Park, 1873. Washington. Government Printing Office, 1875.

Kalmbach, E. R. and Coburn, Don R.

1937. Disease factors in reported cases of starvation in waterfowl. Transactions of the Second North American Wildlife Conference, pp. 404-410. 


\section{Ecology of the Coyote in the Yellowstone}

LANGFORD, N. P.

1870. The Discovery of Yellowstone Park. J. E. Haynes, St. Paul. Second Edition. Ludlow, William

1876. Report of a reconnaissance from Carrol, Montana Territory, on the Upper Missouri to the Yellowstone National Park and return madc in the summer of 1875. Washington, Government Printing Office, pp. 1-155.

\section{Marsh, Hadleigh}

1938. Pneumonia in Rocky Mountain bighorn sheep. Journal of Mammology, Vol. 19, No. 2, pp. 214-219.

Mills, Harlow B.

1937. A preliminary study of the bighorn of Yellowstone National Park. Journal of Mammology, Vol. 18, No. 2, pp. 205-212.

Murie, Adolph

1934. Following fox trails. Miscellaneous Publications No. 32, Museum of Zoology, University of Michigan.

Murie, Olaus J.

1935. Food habits of the coyote in Jackson Hole, Wyoming. Unitcd States Department of Agriculture Circular No. 362, pp. 1-24.

PierRepont, EdWARd

1884. Fifth Avenue to Alaska. G. P. Putnam Sons, New York, 1884, 329 pp. Maps by Leonard Forbes Beckwith.

Pike, Warburton

1892. Barren ground of northern Canada. Macmillan \& Co.

Potts, Merlin K.

1938. Observations on diseases of bighorn in Rocky Mountain National Park. Transactions of the Third North American Wildlife Conference, pp. 893897.

Pough, Richard H.

1939. Present status of the trumpeter swan. Bird Lore, Vol. 51, No. 1, p. 46.

Presnall, C. C.

1938. A survey of the deer situation in Zion Canyon, Utah. Utah Academy of Sciences, Arts and Letters. Vol. 15, pp. 107-110.

Rush, William M.

1932. Northern Yellowstone elk study. Montana Fish and Game Commission. Missoula, Montana. pp. 1-131.

\section{Russell, Osborne}

1921. Journal of a trapper, 1834-1843. Boise, Idaho, 1921, 149 pp.

Santee, Richard and Granfield, William

1939. Behavior of the saw-whet owl in its nesting grounds. The Condor, Vol. 41, No. 1, January-February, 1939.

Shillinger, J. E. and Cottam, Glarence C.

1937. The importance of lead poisoning in waterfowl. Transactions of the Second North American Wildlife Conference, pp. 398-403.

\section{Skinner, Milton P.}

1927. The predatory and fur-bearing animals of the Yellowstone National Park.

Roosevelt Wildlife Bulletin, Vol. 4, No. 2, pp. 1-284. 


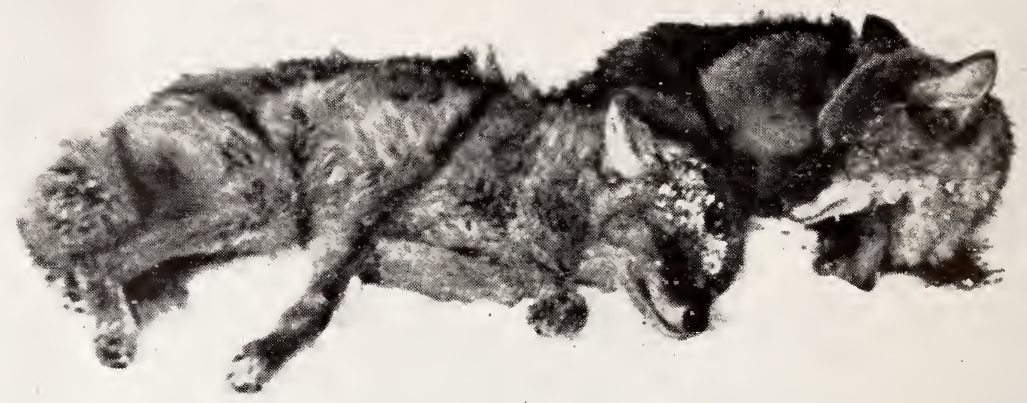

Figure 1.-COYOTES IN A WEAKENED CONDITION, UNABLE TO RUN AWAY, FOUND AT TOWER FALLS IN FEBRUARY 1937, BY RANGER DAVID D. CONDON.

Photo by D. D. Condon, February 1937.

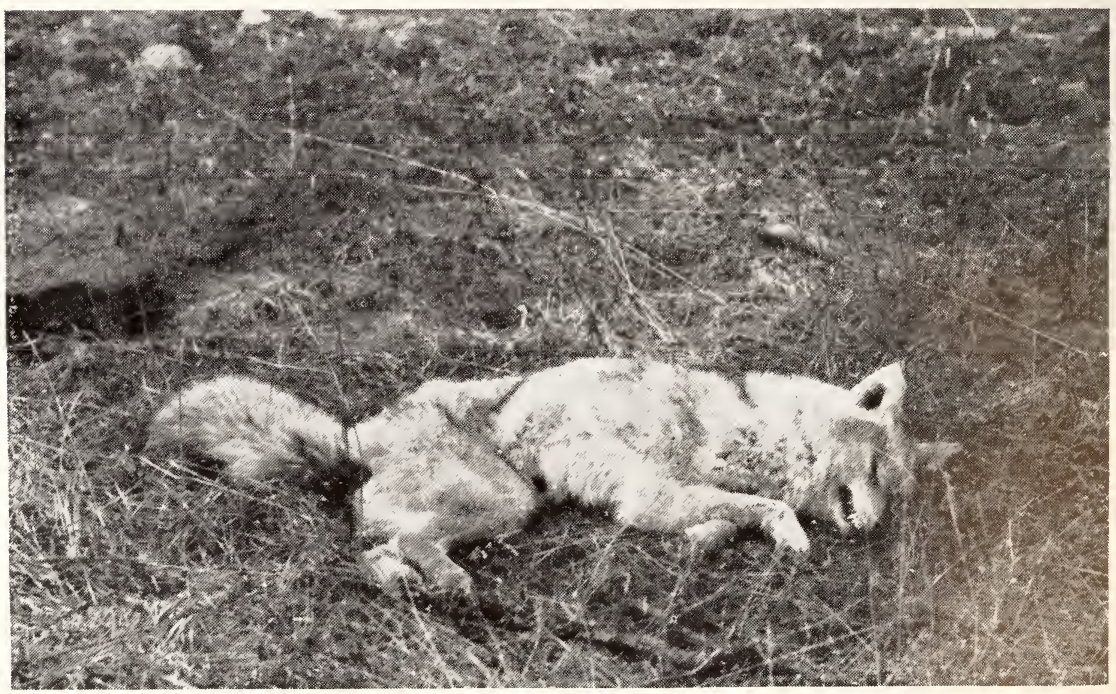

Figure 2.-FEMALE COYOTE FOUND DEAD UNDER A BUILDING AT YELlOWSTONE LAKE. THIS EMACIATED ANIMAL WEIGHED ONLY $13 \%$ POUNDS AND HAD AN UlGERATED SORE ON ITS BACK. Yellowstone Lake, May 11, 1937. 


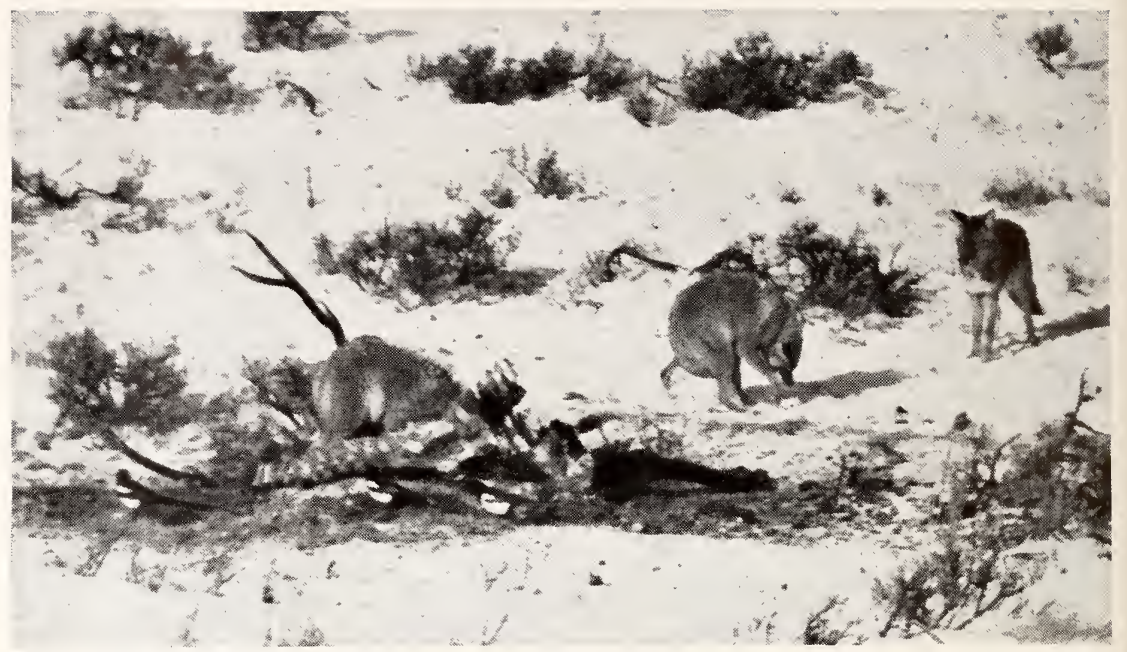

Figure 4.- THE COYOTE IN THE CENTER IS TRYing TO BLUFF THE NEWCOMER AT THE RIGHT, BUT WITHOUT MUCH SUCCESS. THIS CHALLENGING ATTITUDE IS FREQUENTLY ASSUMED BY COYOTES WHILE AT A CARCASS. Blacktail Deer Creek, November 11, 1938.

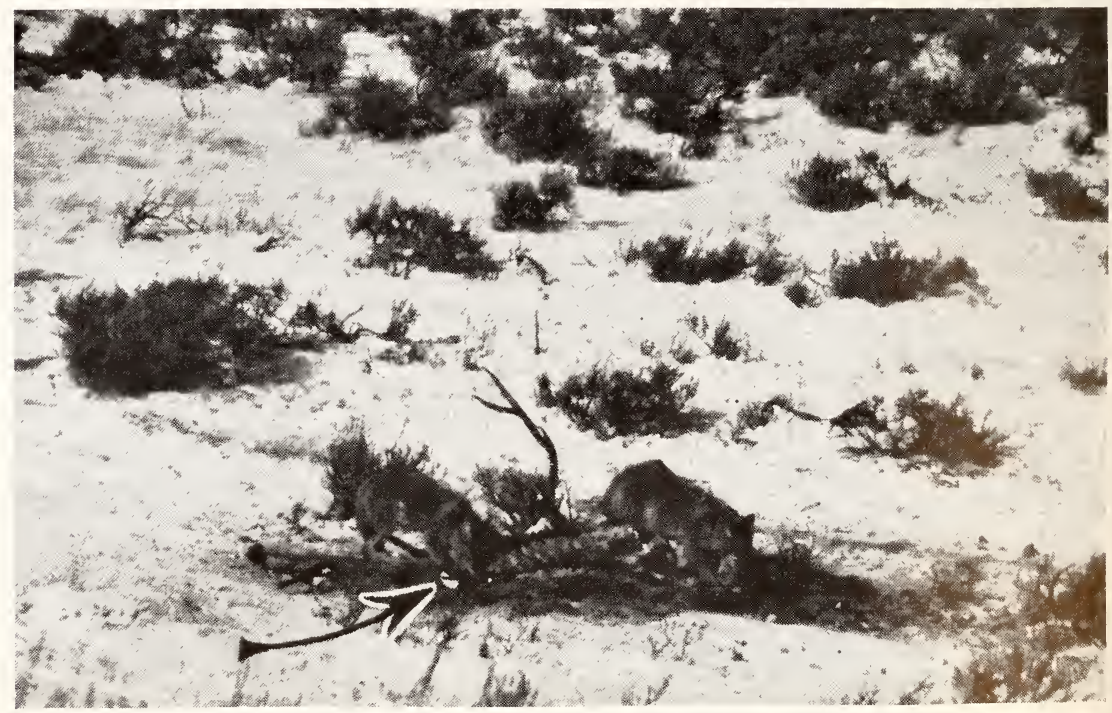

Figure 5. - A MAGPIE (INDICATED BY ARROW) IS FEEDING ONLY A COUPLE OF FEET FROM THE HEAD OF A COYOTE. Blacktail Deer Creek, November 14, 1938. 


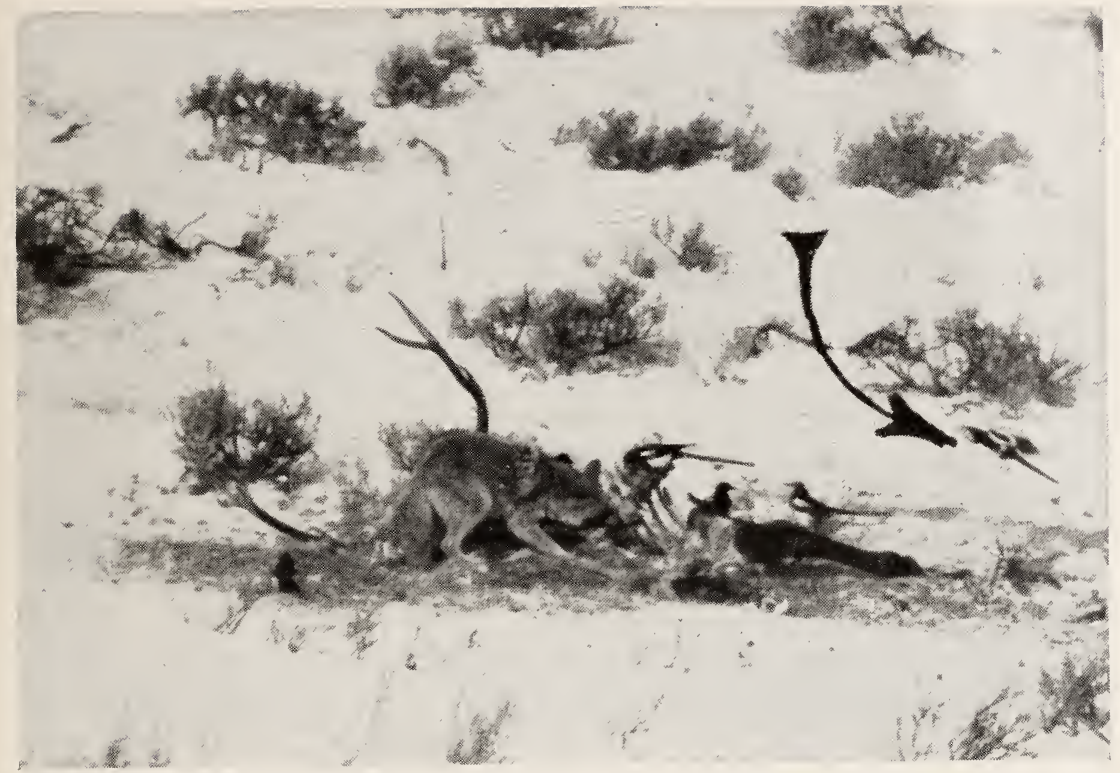

Figure 6.-MAgPIES AND A COYOTE FEEDING ON AN ELK CARCASS. THE FLYING MAGPIE (INDICATED BY ARROW) IS RETURNING FROM A TRIP TO THE WOODS TO GACHE A MORSEL. Blacktail Deer Creek, November 14, 1938. 
COYOTE AND RAVEN

$$
\text { AT PLAY }
$$

Sketched from Life

$$
\text { B) }
$$

0. 7. Murie

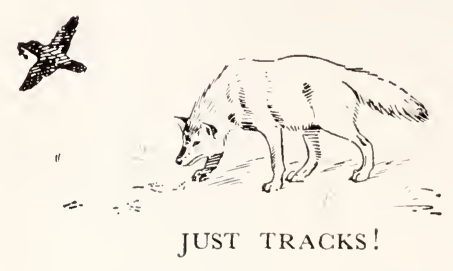

$-2$

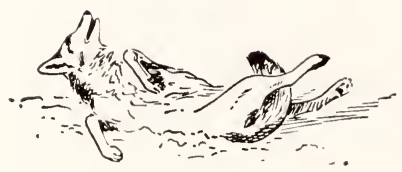

ALL IN A HEAP
T?
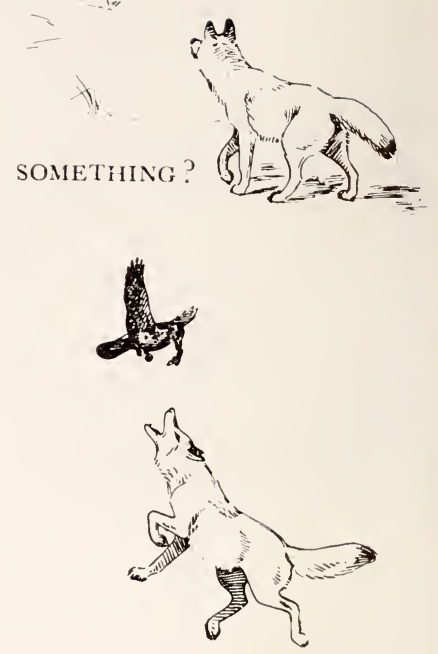

TANTALIZING
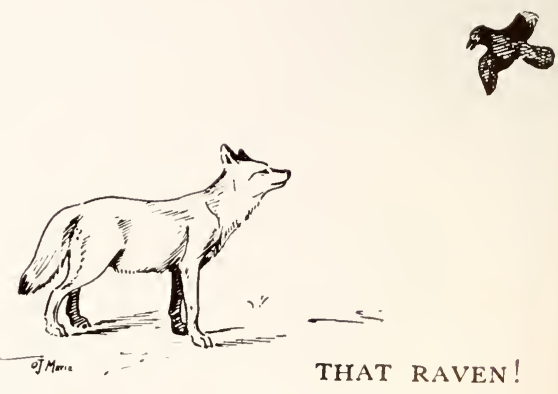

Figure 7 


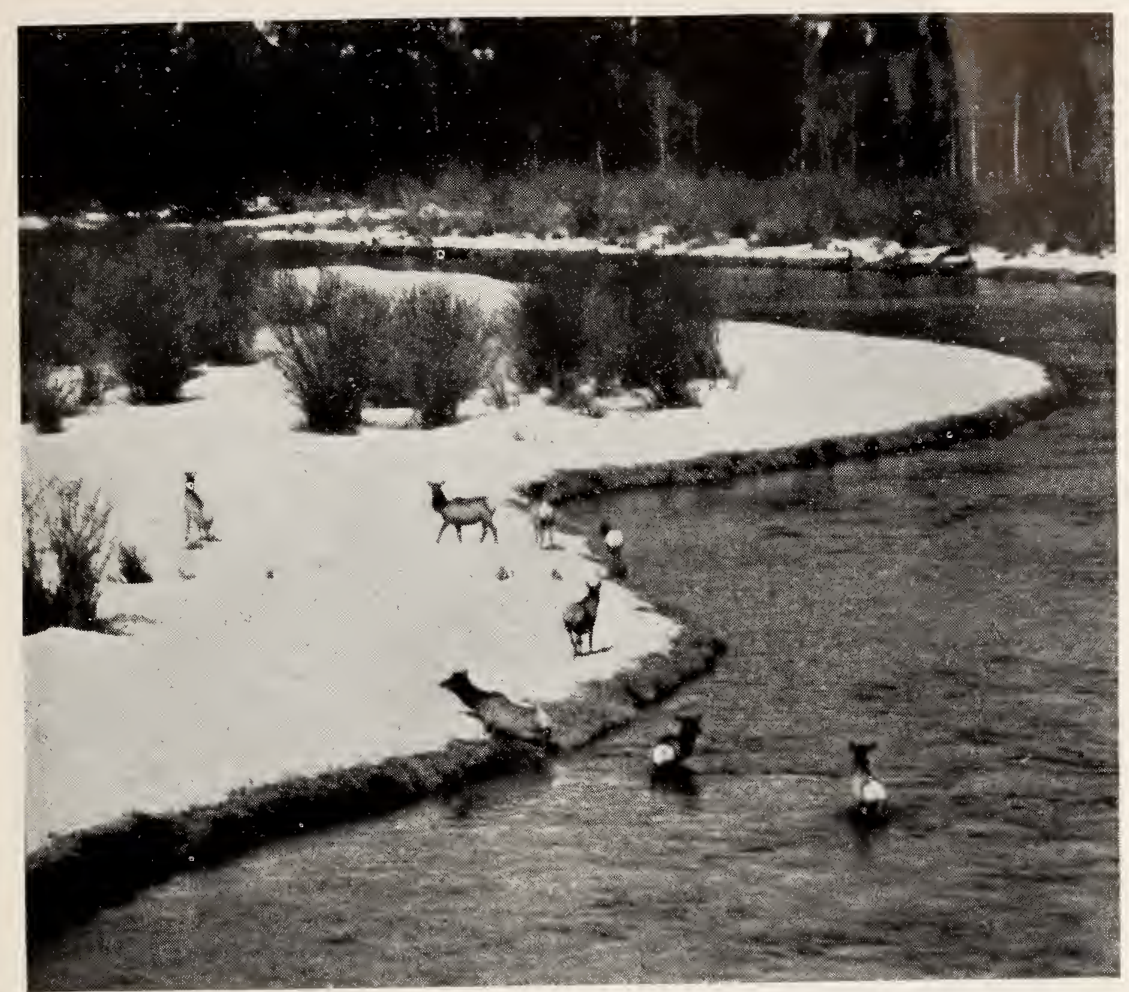

Figure 8. - THE COW WHICH HAS FALIEN WAS WEAK AFTER THE WINTER SEASON OF FOOD SCARCITY. NOTE THE CLOSELY GRAZED BANKS ALONG THE RIVER.

Madison River, April 16, 1938. 


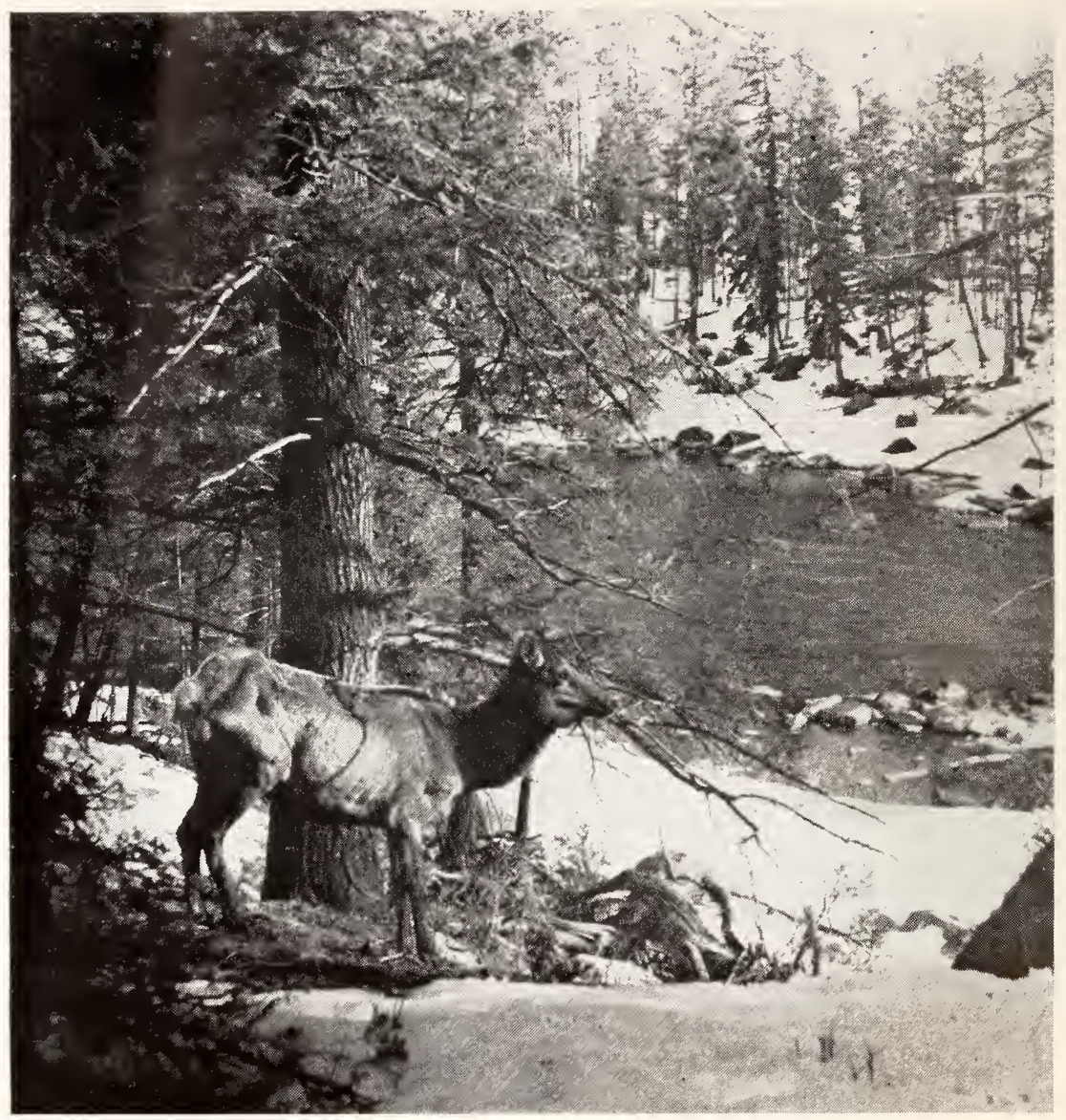

Figure 9.- AFTER A HARD WINTER THIS COW WAS SO WEAK THAT SHE GOULD HARDLY RISE AND STAND. NOTE THE ODD APPEARANCE OF THE LOWER JAW WHILE "GRINDing" The MOLARS, AN ACTION COMMON TO MANY UNGULATES WHEN IN GREAT DISCOMFORT OR ANGER. Below Cottonwood Creek, March 4. 1938. 

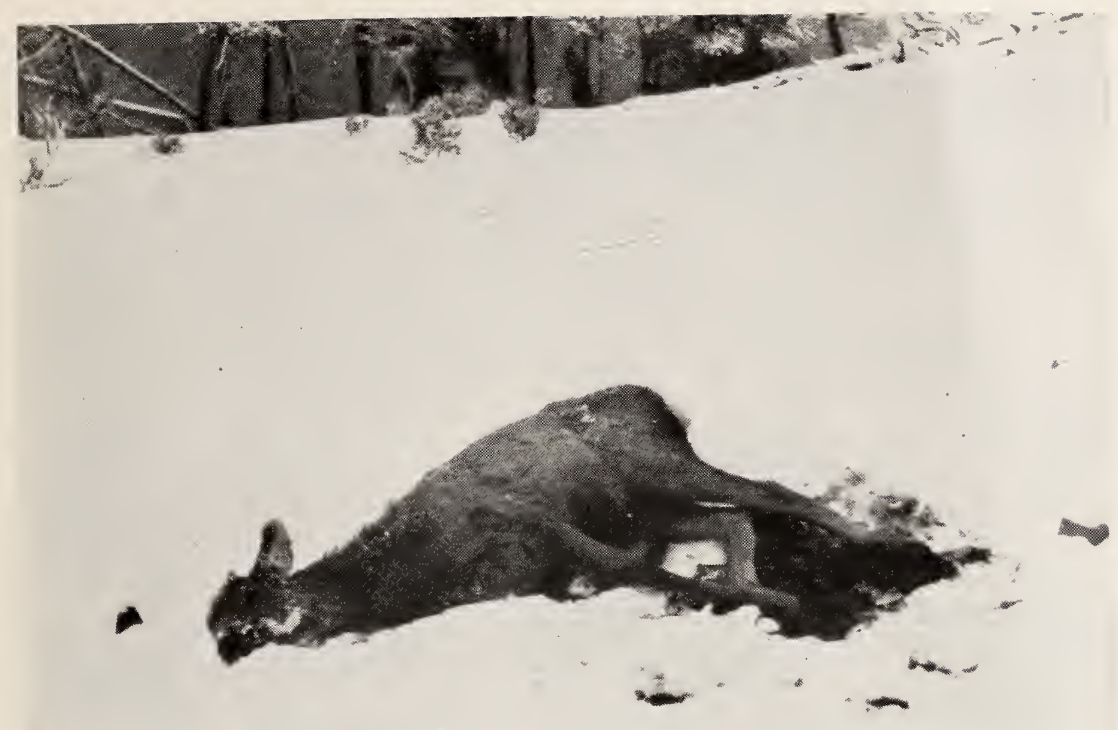

Figure 10. - A WEAK CALF ElK. DURING THE LATter PART OF EACH WINTER A NUMBER OF SUCH CALVES USUALly DIE FROM DISEASE OR MALNUTRITION.

Below Coitonwood Creek, March 20, 1938.

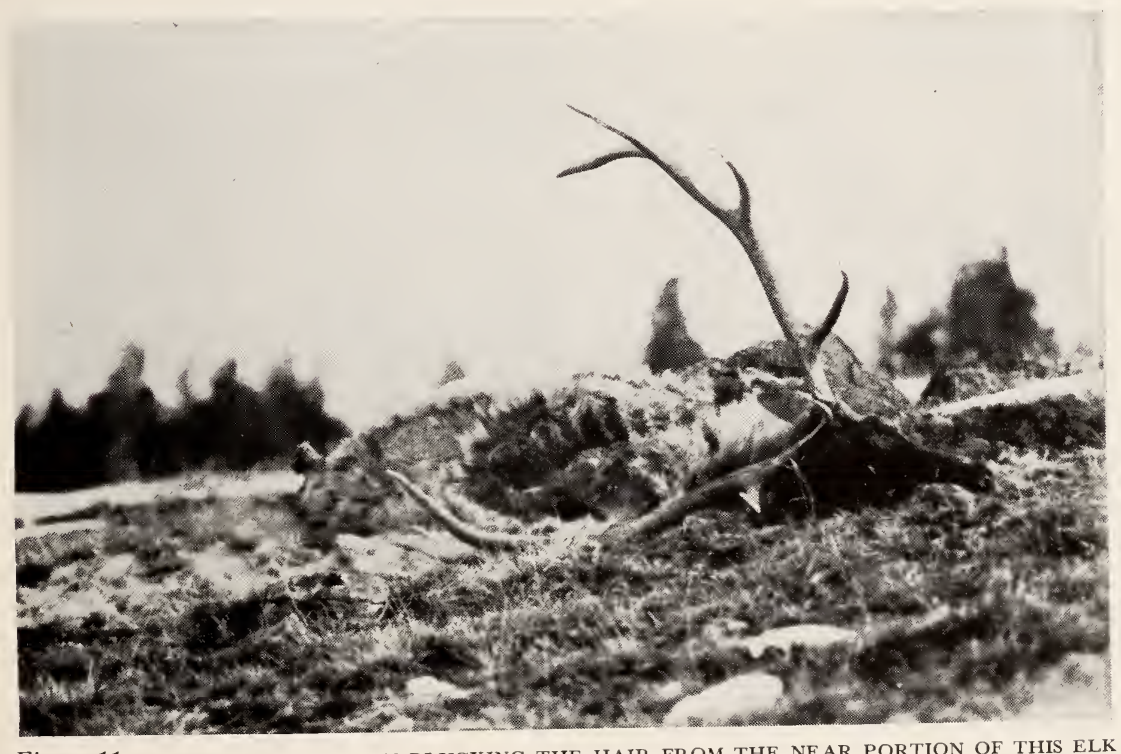

Figure 11. - A COYOTE WAS SEEN PLUCKING THE HAIR FROM THE NEAR PORTION OF THIS ELK Garcass While a Raven sat on An Antler Watching him. Swan Lake Flat, April 12, 1938. 


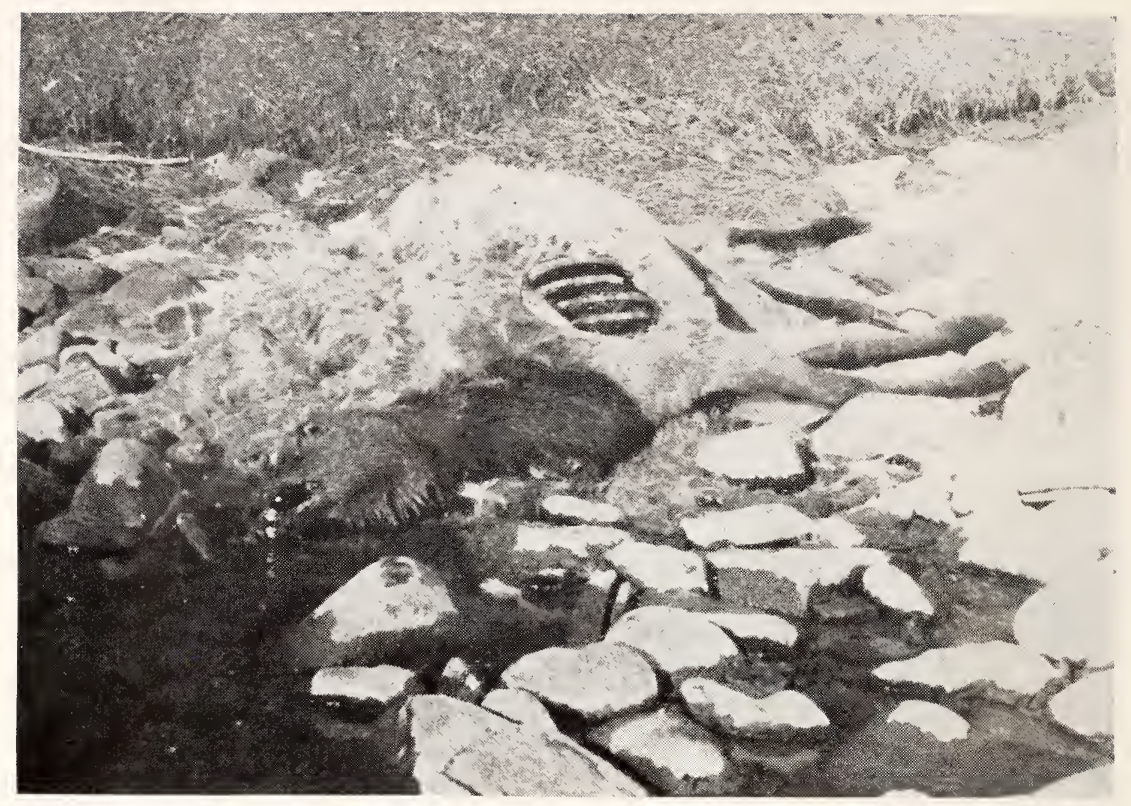

Figure 12.- SO MANY ELK DIED IN 1938 THAT THE COYOTES WERE UNABLE TO CLEAN UP THE CARCASSES AND THUS MINIMIZE WATER POLLUTION, AS IN OTHER YEARS. 


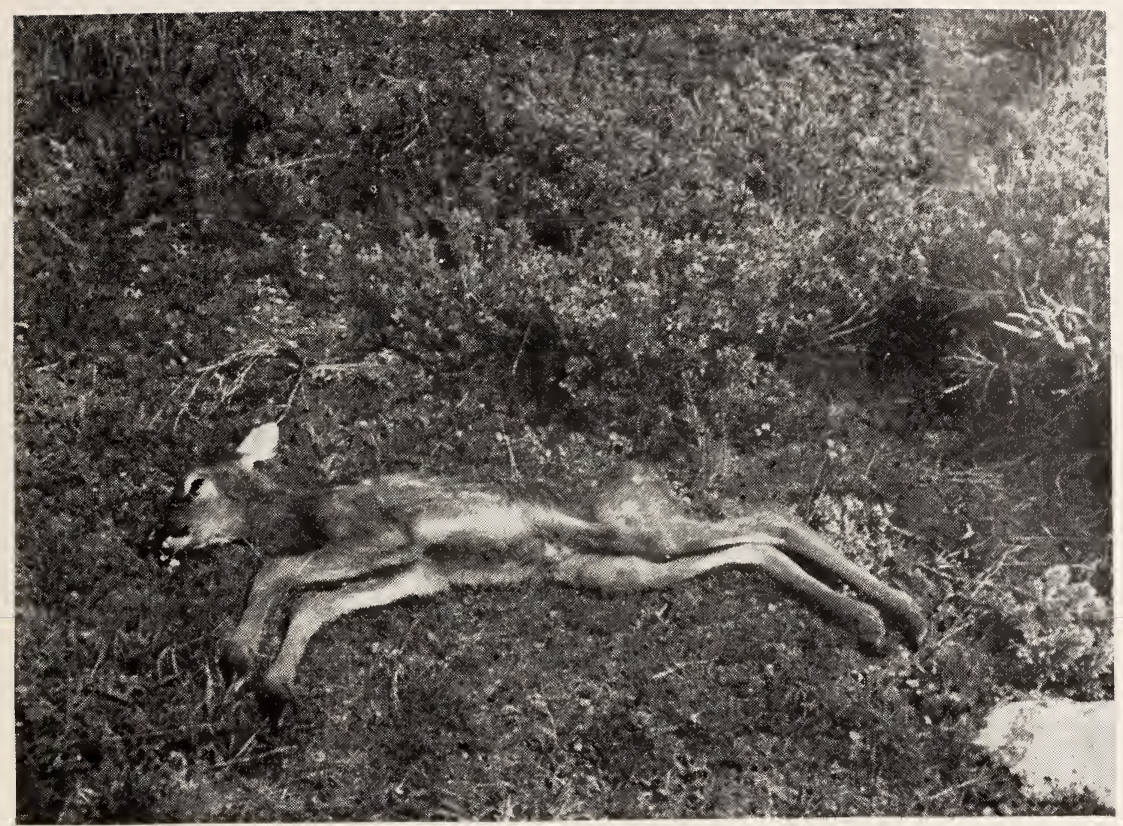

Figure 13. - A CALF ELK THAT DIED AT BIRTH BUT WAS NOT YET DESERTED BY THE MOTHER. It FORMS POTENTIAl CARRION fOr coyotes. Base of Hellroaring Slopes, May 24, 1938. 


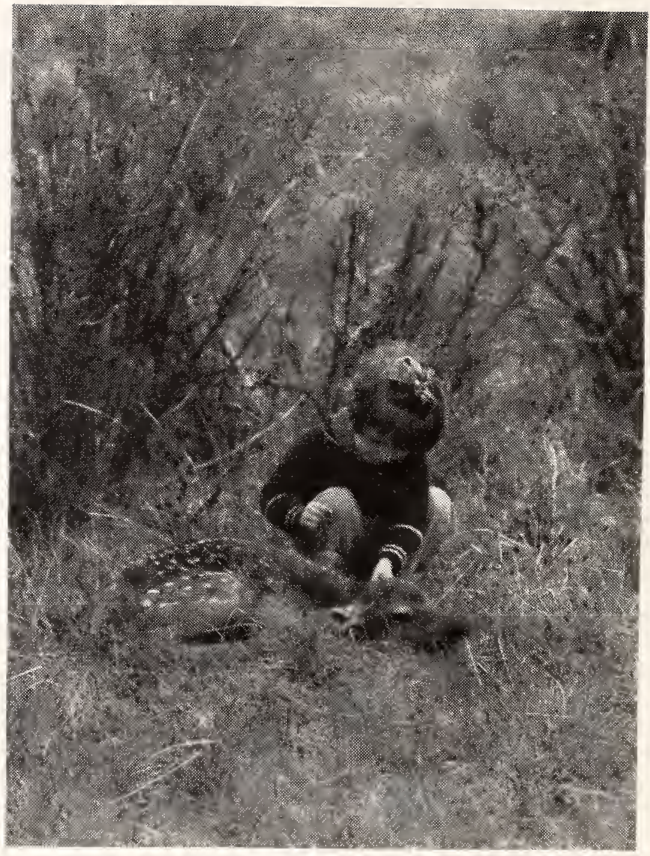

Figure 14.-A VERY YOUNG CALF ELK SHOWS REMARKABLE FAITH IN HIDING AND ALLOWS ITSELF TO BE HANDLED. SOON GALVES BEGOME LESS TOLERANT AND RUN AWAY WHEN APPROACHED TOO GLOSELY. Tower Falls, May 29, 1938. 


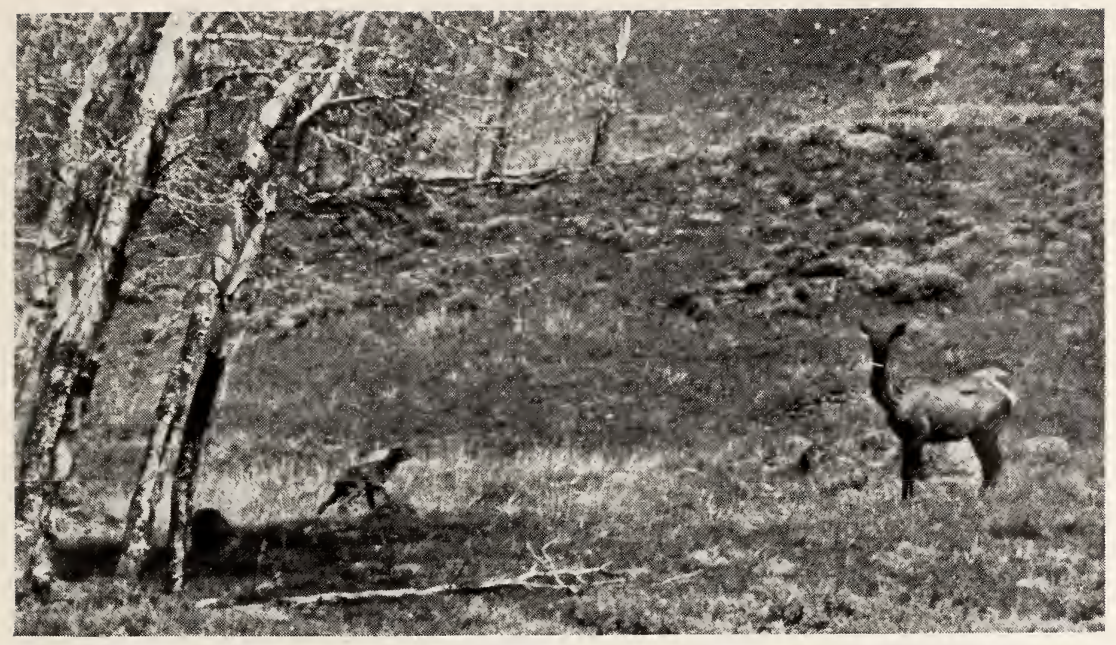

Figure 15.-ELK COW SLOWLY ENTICING CALF LESS THAN 24 HOURS OLD AWAY FROM ASPEN GROVE IN WHICH IT WAS BORN. Junction Butte, May 25, 1938.

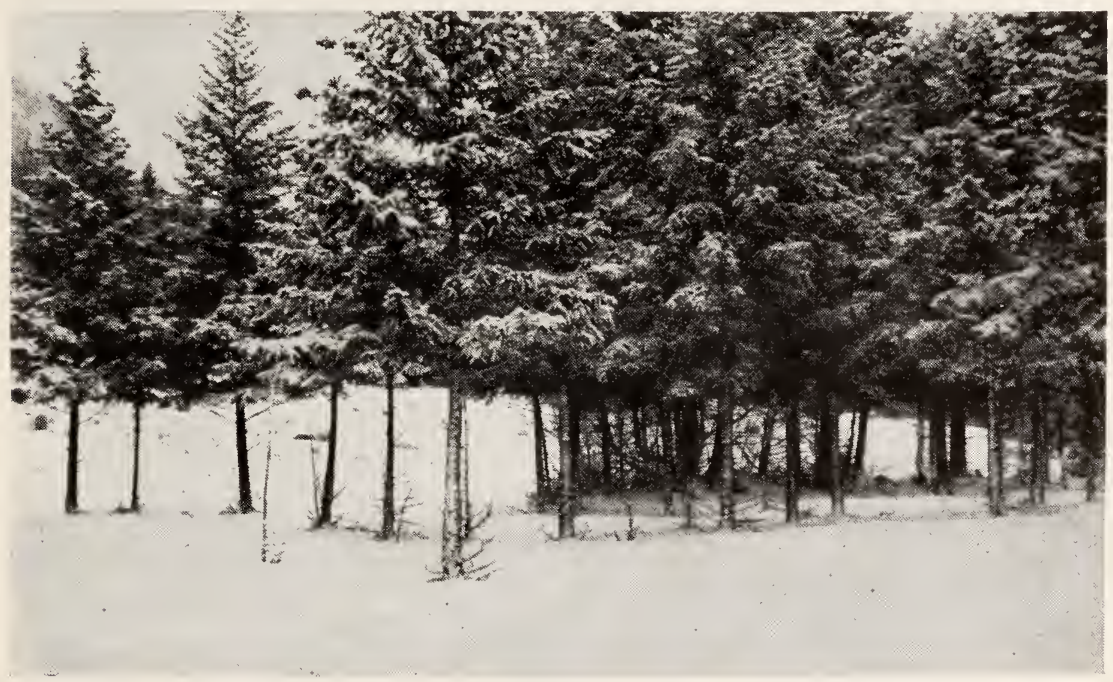

Figure 16.- BROWSE LiNe ON DOUglas FIR ALONG THE YEllowstone River ABOVE BLACKTAIL DEER CREEK: A TYPICAL CONDITION MAKING THIS A POOR DEER RANGE. March 21, 1938. 


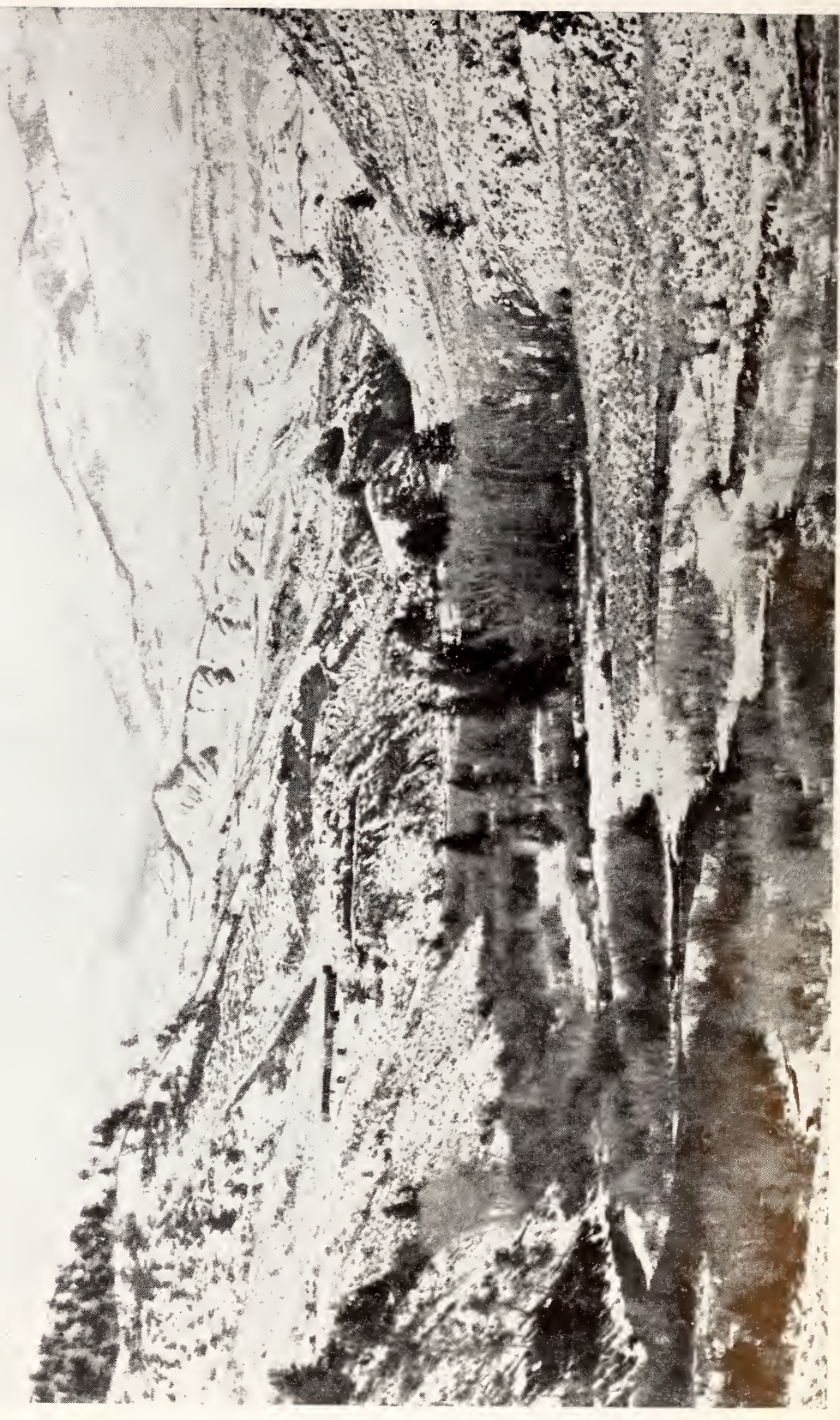




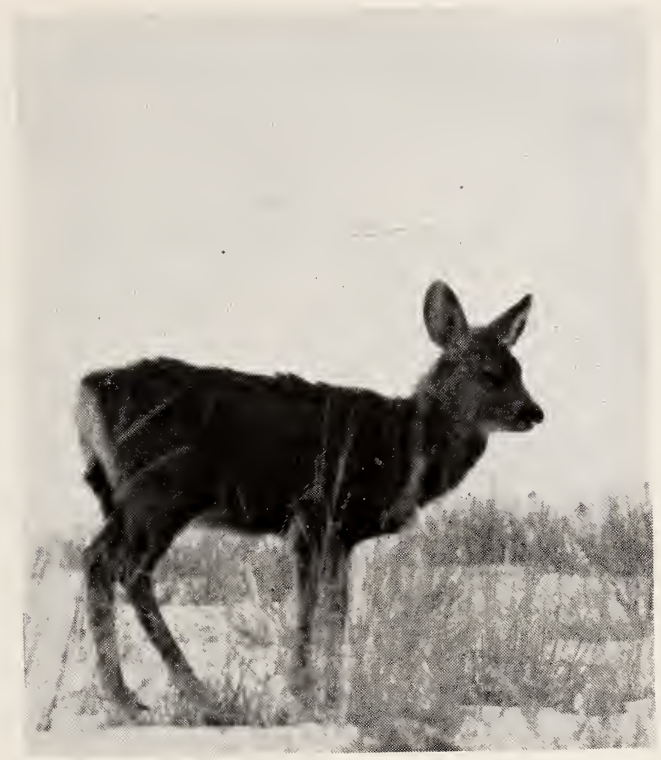

Figure 18. - A THIN, WEAK FAWN DEER WHICH PROBABLY SUCCUMBED BEFORE SUMMER.

Near Mammoth Springs, March 29. 1938. 


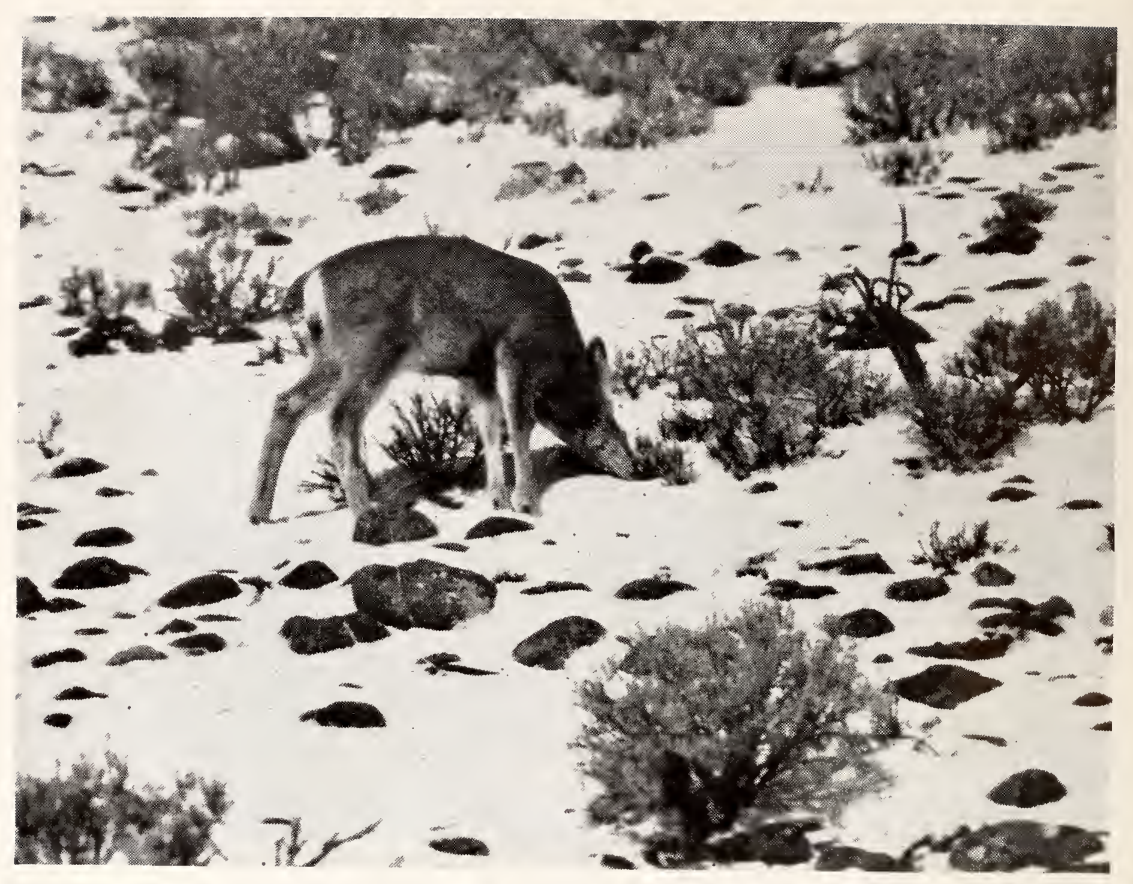

Figure 19.- FAWN DEER REACHING FOR SAGEBRUSH TWIGS EXPOSED DURING A THAW. THE SAGEBRUSH IN THIS AREA WAS HEAVILY BROWSED. Gardiner River, March 25, 1938. 


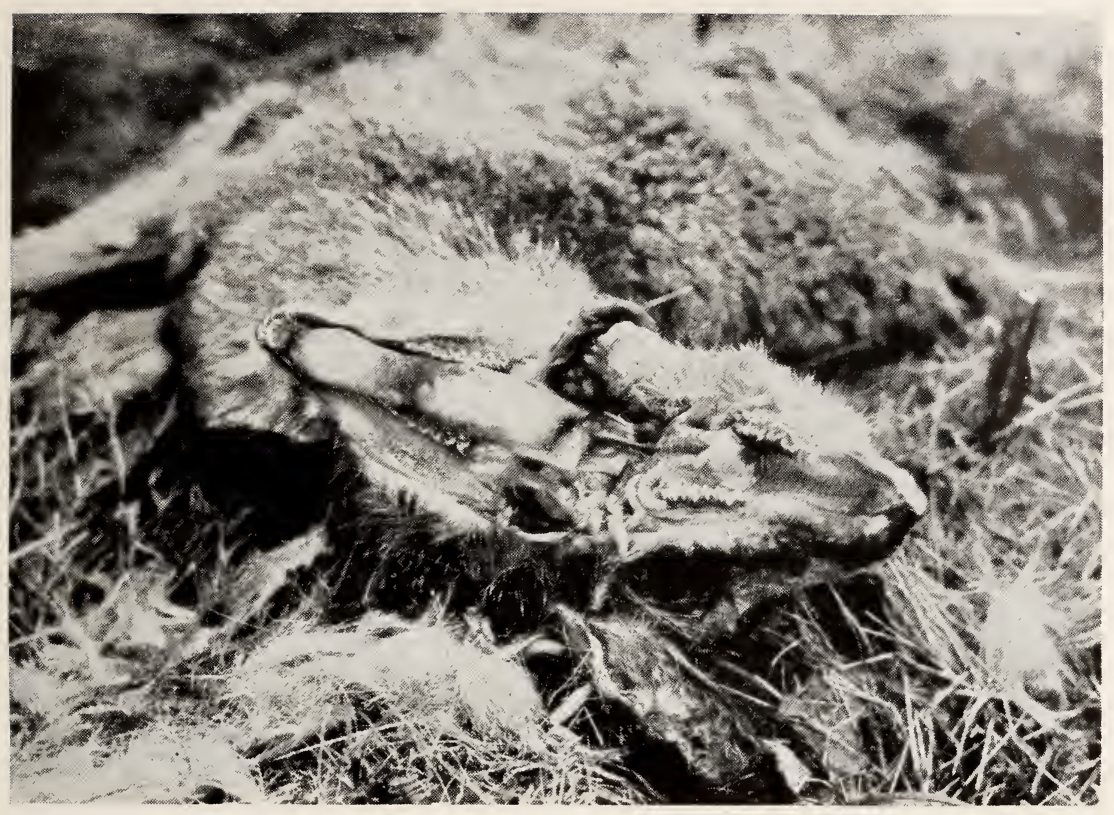

Figure 20.- THE OPENED MOUTH OF A FAWN DEER SHOWING SOME OF THE 52 NOSE FLI LARVAE FOUND IN GULAR POUGH AND THROAT. IT HAD DIED FROM SOME GAUSE OTHER THAN PREDATION. Tower Falls, April 15, 1938. 


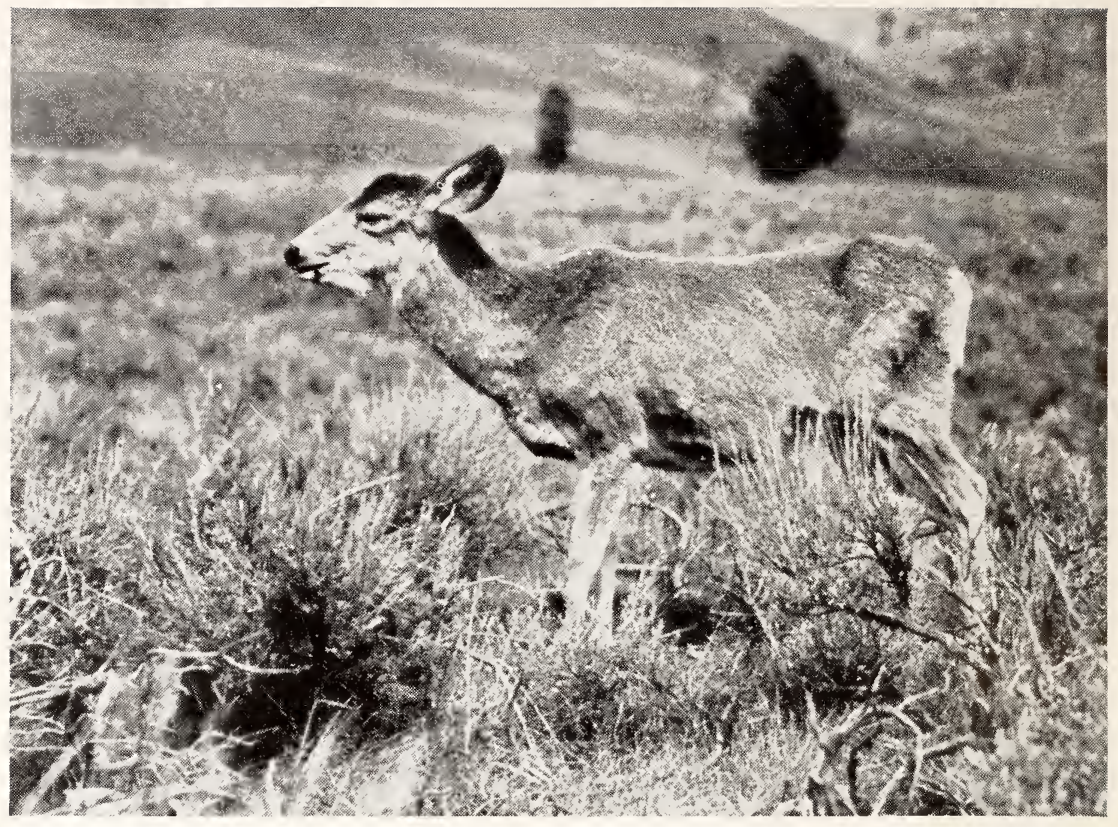

Figure 21. - AN Old DOE AFTER a HARD Winter. THIS ANIMAL WAS DROOling, had A LUMP ON THE JAW, AND WAS APPARENTLY SICK BEYOND RECOVERY.

Tower Falls, April 28, 1938. 


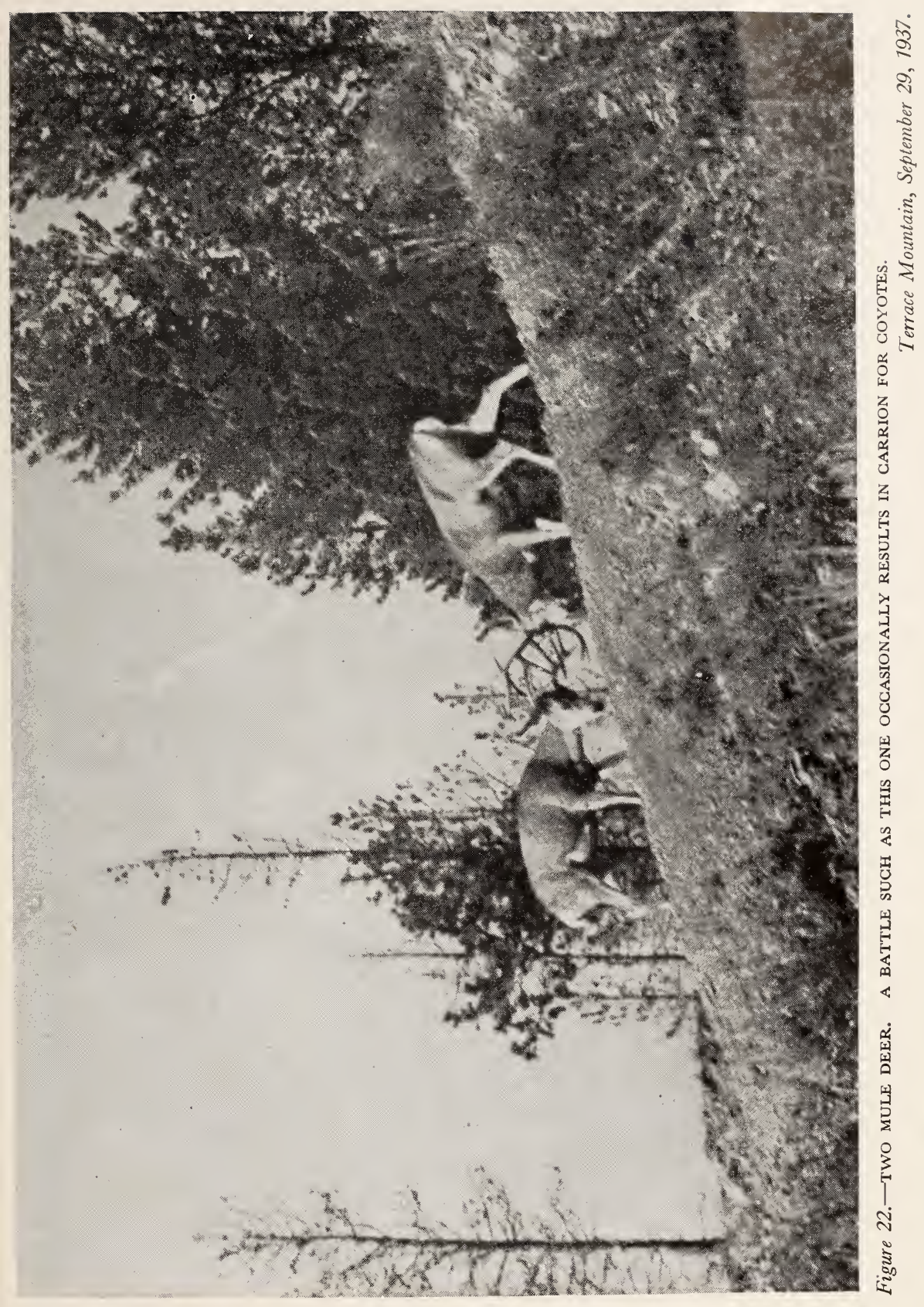




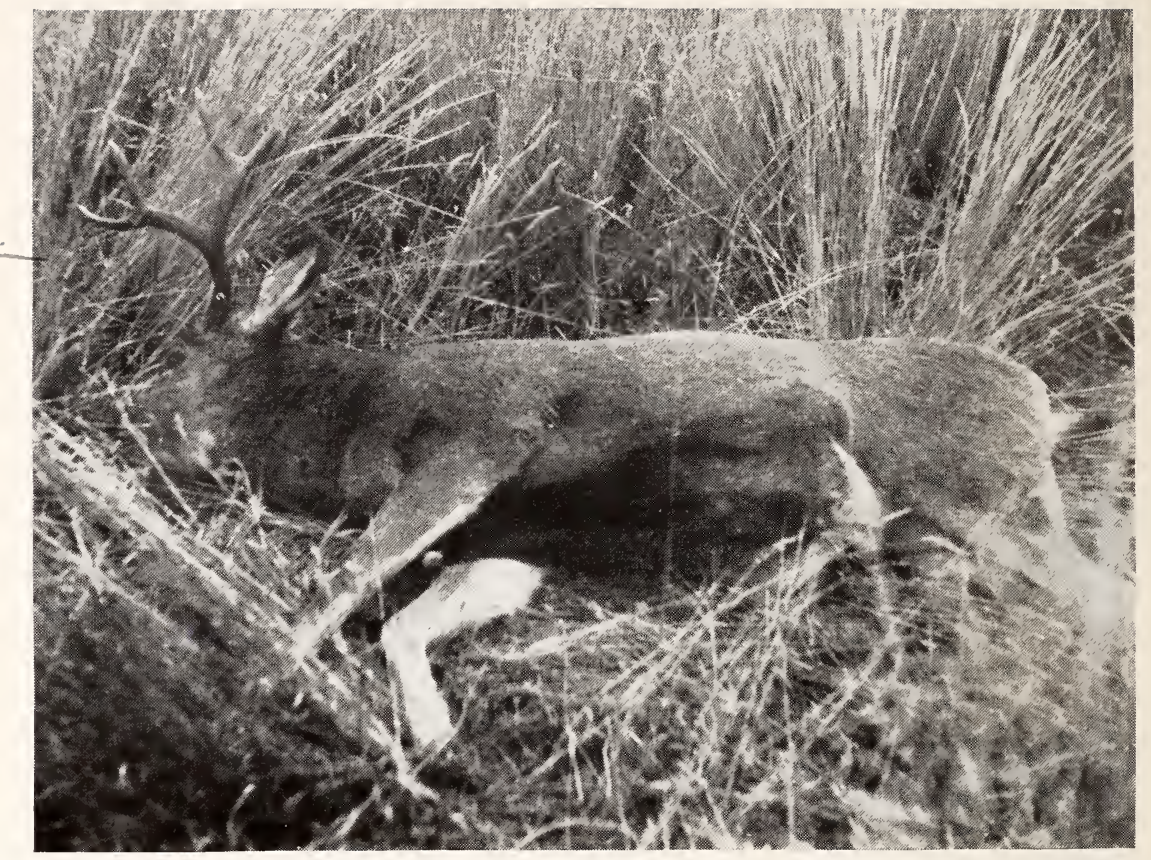

Figure 23.-BUCK DEER KILLED BY ANOTHER BUCK DURING THE RUT. IT WAS WOUNDED INSIDE THE HIND LEG AND IN THE ABDOMINAL CAVITY WHERE A TINE APPARENTLY PIERGED AN ARTERY NEAR THE VERTEBRAE. Game Ranch, November 13, 1937. 


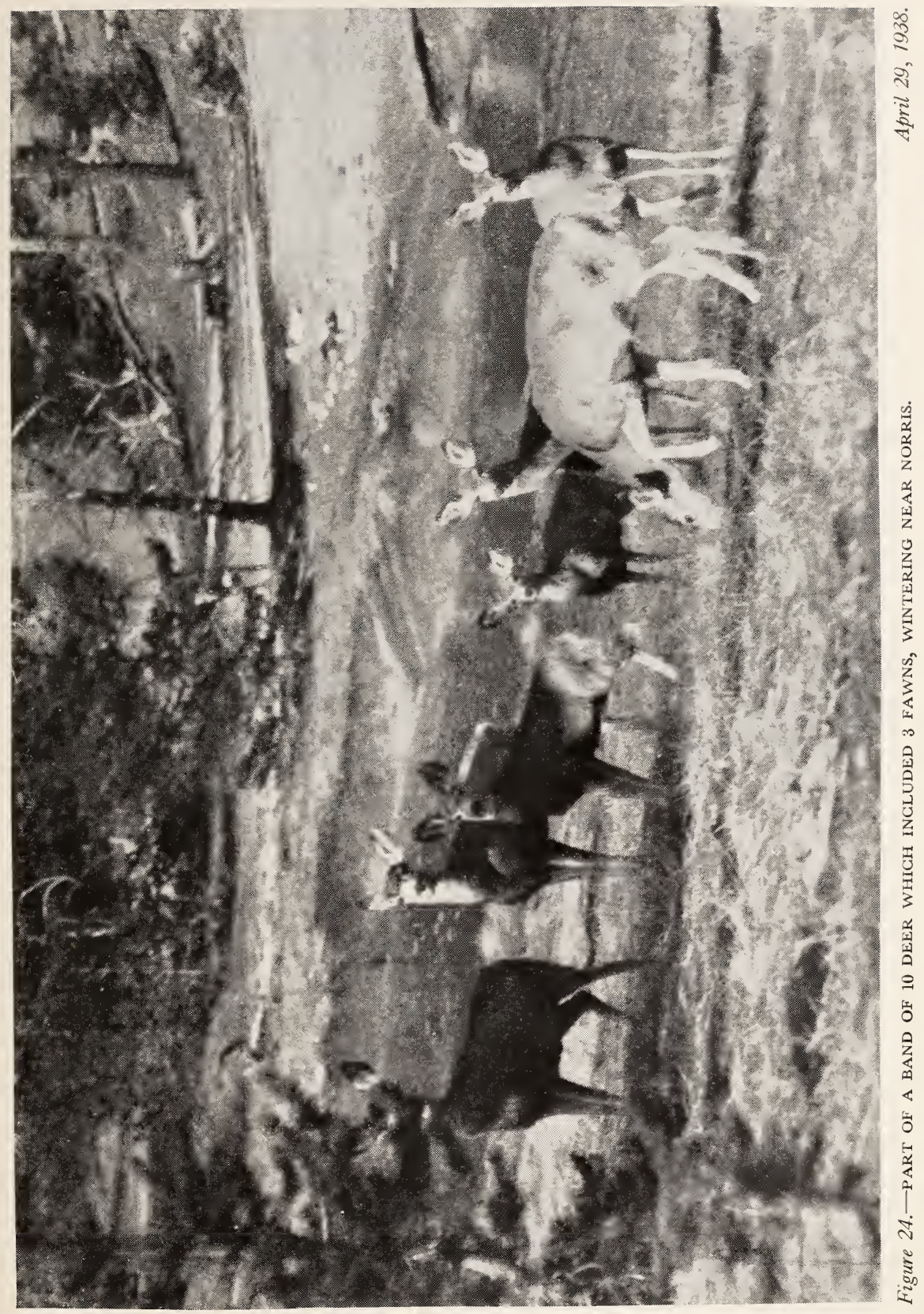




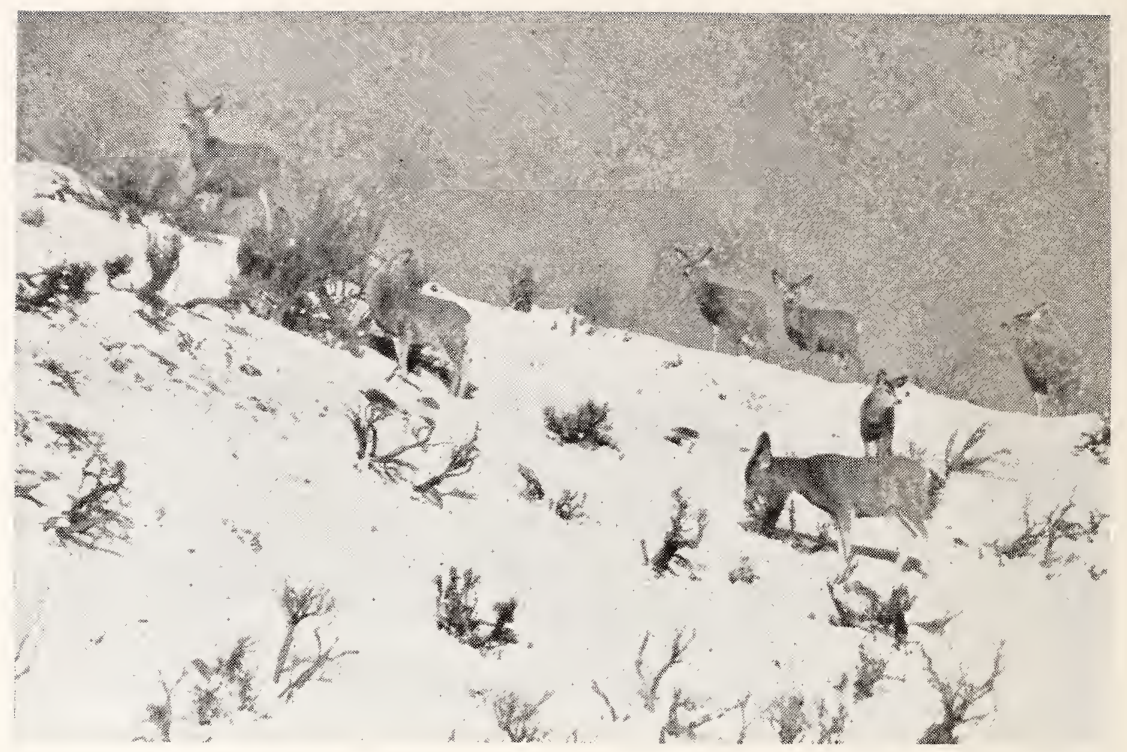

Figure 25.-THE TWO FAwNS ON THE LEFT SIDE ARE FEEDING ON GREASEWOOd (Sarcobatus). MUCH OF THE HEAVILY BROWSED SAGEBRUSH HAS BEEN KILLED.

Slope near Gardiner River, March 25, 1938. 


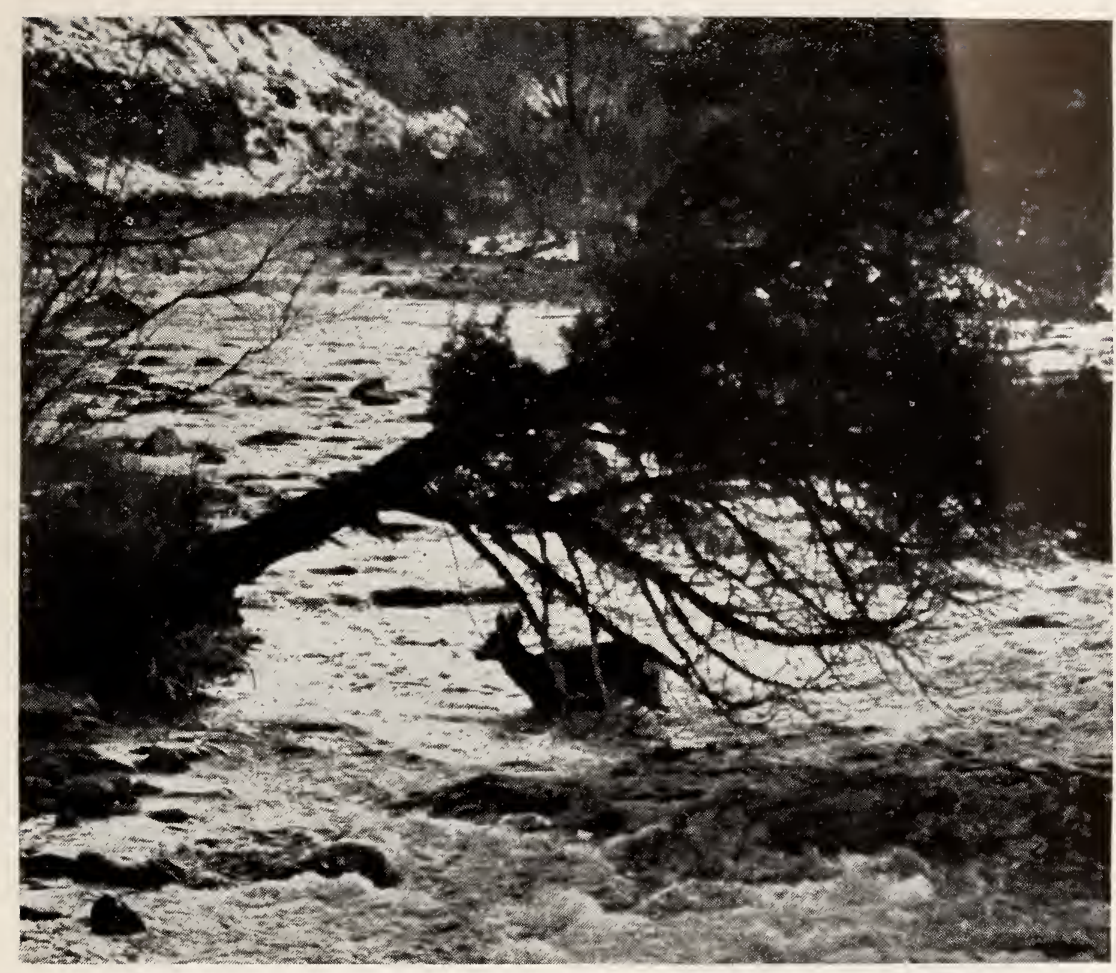

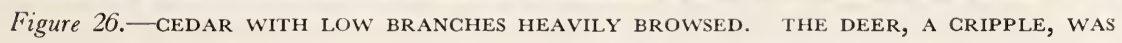
LEFT BEHIND WHILE 5 OTHERS RAN AT OBSERVER'S APPROACH.

Gardiner River, January 16, 1938. 


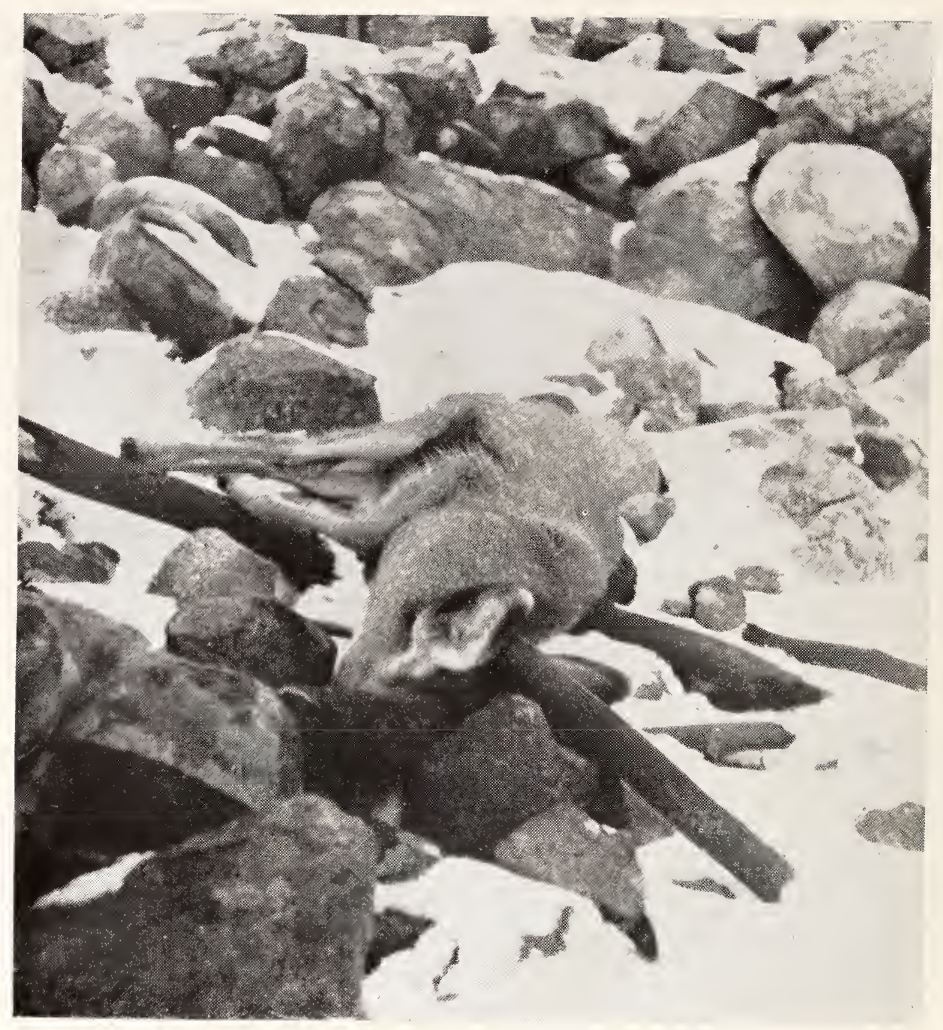

Figure 27.-WEAK DEER FAWN WHICH WAS FOLLOWED BY THE WRITER UNTIL it COLlapsed AS SHOWN. THE INCIDENT IS DESGRIBED IN THE SEGTION "Coyote method of hunting fawns." $\quad$ Crevice Creek, March 19, 1938. 


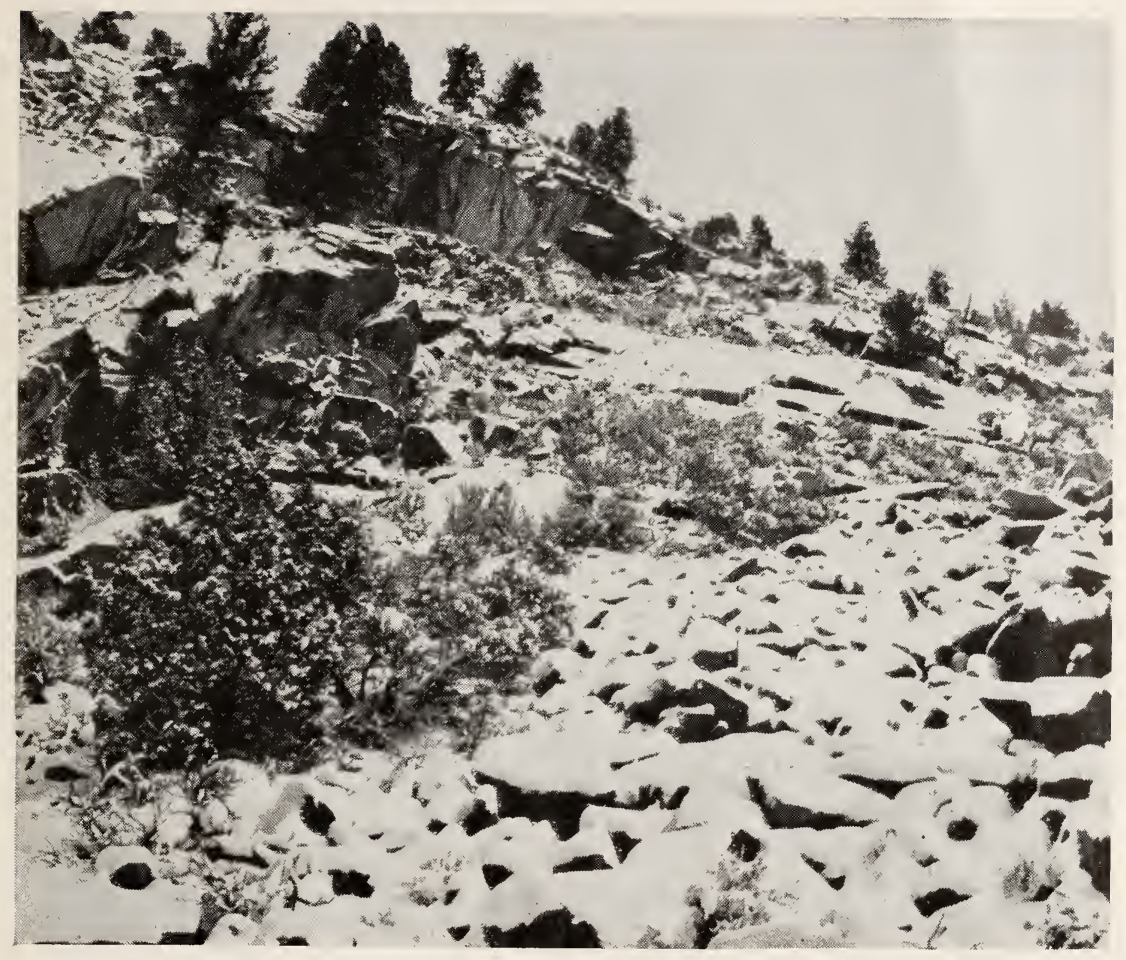

Figure 28. - WINTER RANGE ALONG THE YELlOWSTONE RIVER BELOW CREVICE CREek, SHOWING TERRAIN LIKELY TO GAUSE BROKEN LEGS AMONG DEER.

March 21, 1938. 


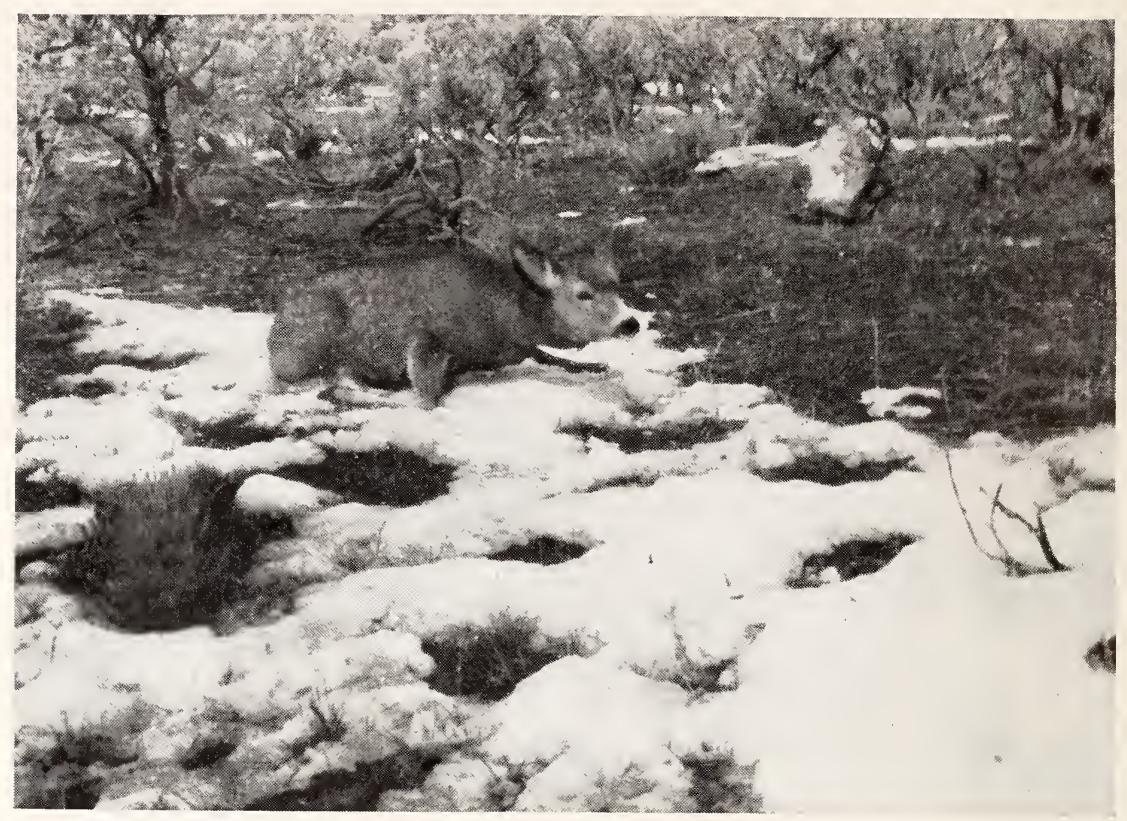

Figure 29.-AN OLD DOE WITH TEETH WORN TO THE GUMS, SOME OF THEM WORN IN TWO. March 7, 1938. 


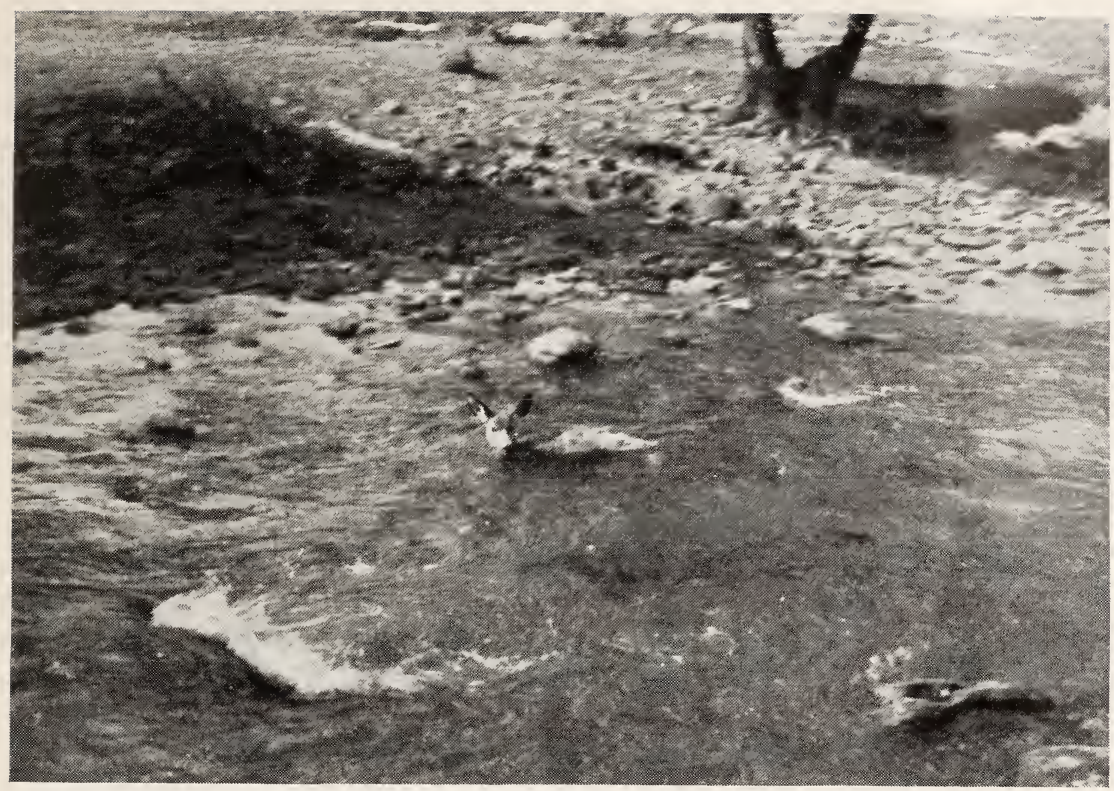

Figure 30.-THE OLD DOE MANAGED TO RISE AND WALK TO THE GARDINER RIVER, WHERE SHE FELL AND COULD NOT RISE.

March 7, 1938.

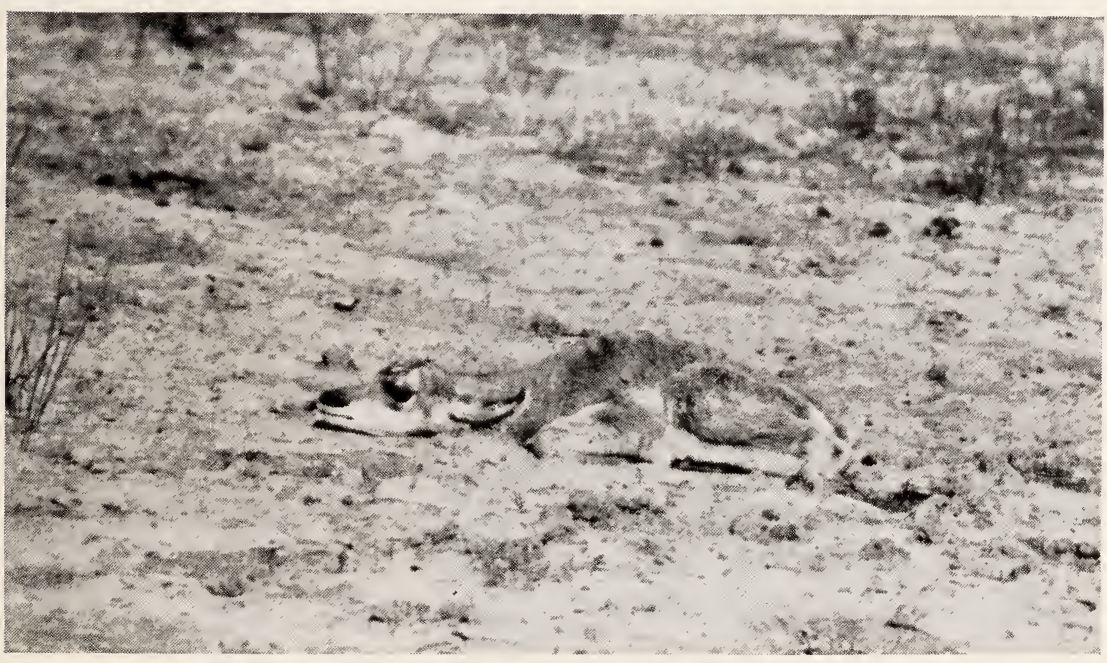

Figure 31. - THE DULL, GREYISH BROWN OF AN ANTELOPE FAWN BLENDS WELL WITH THE SAGEBRUSH AND THE GROUND, MAKING IT MORE DIFFICULT TO FIND THAN THE CONSPICUOUSLY SPOTTED YOUNG OF ELK OR DEER.

Horseshoe, June 11, 1938. 


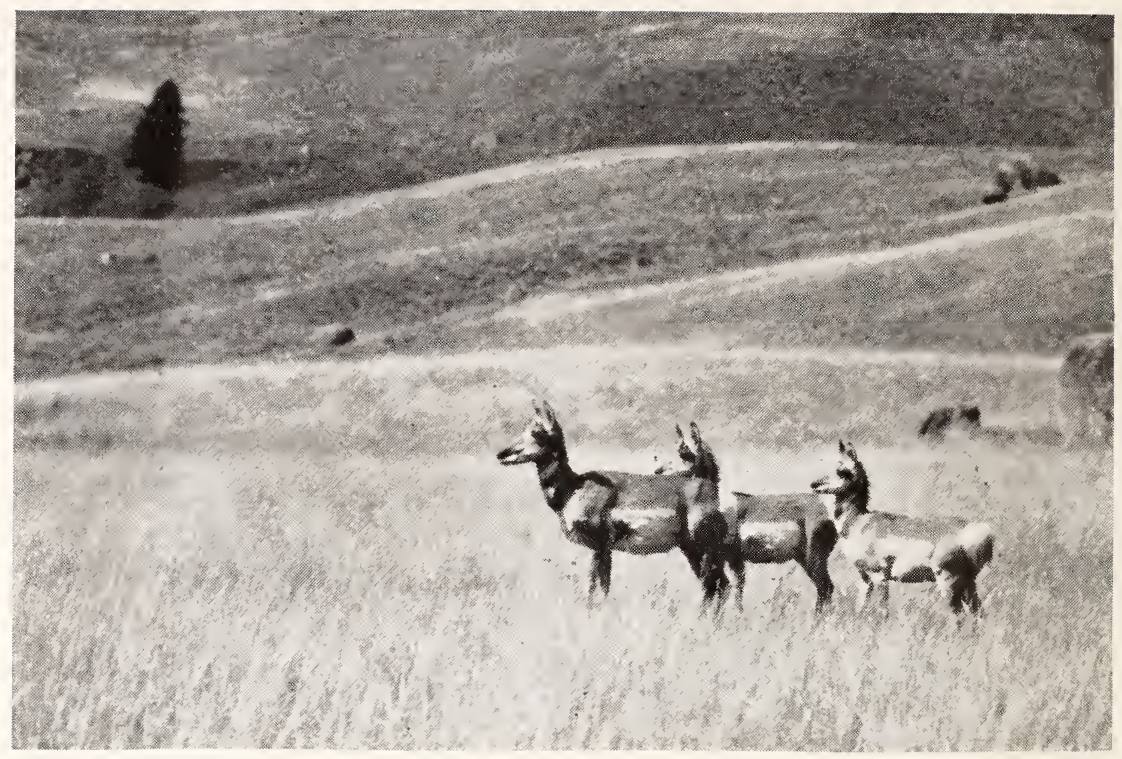

Figure 32.- AN ANTElope doE WITH TWO FAWNS OF NURSING AgE. THE SHORT MUZZles, MANE ON NECK, AND CARRIAGE OF THE HEAD ARE USEFUL CHARACTERS FOR IDENTIFYING FAWNS,

Tower Falls, September 18, 1938.

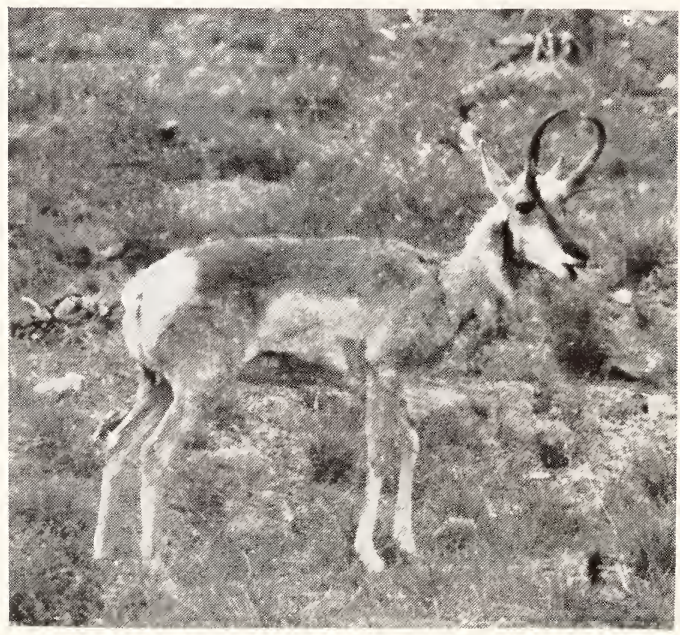

Figure 33. - AMONG THE ANTELOPE SEVERAL CRIPPLES WERE NOTED, SOME OF WHICH NEVERTHELESS TRAVELED FAR. THE BUCK IN THE ILLUSTRATION HAD A STIFF, BENT FORELEG. HE LIVED THE YEAR ROUND NEAR GARDINER. May 22, 1938. 


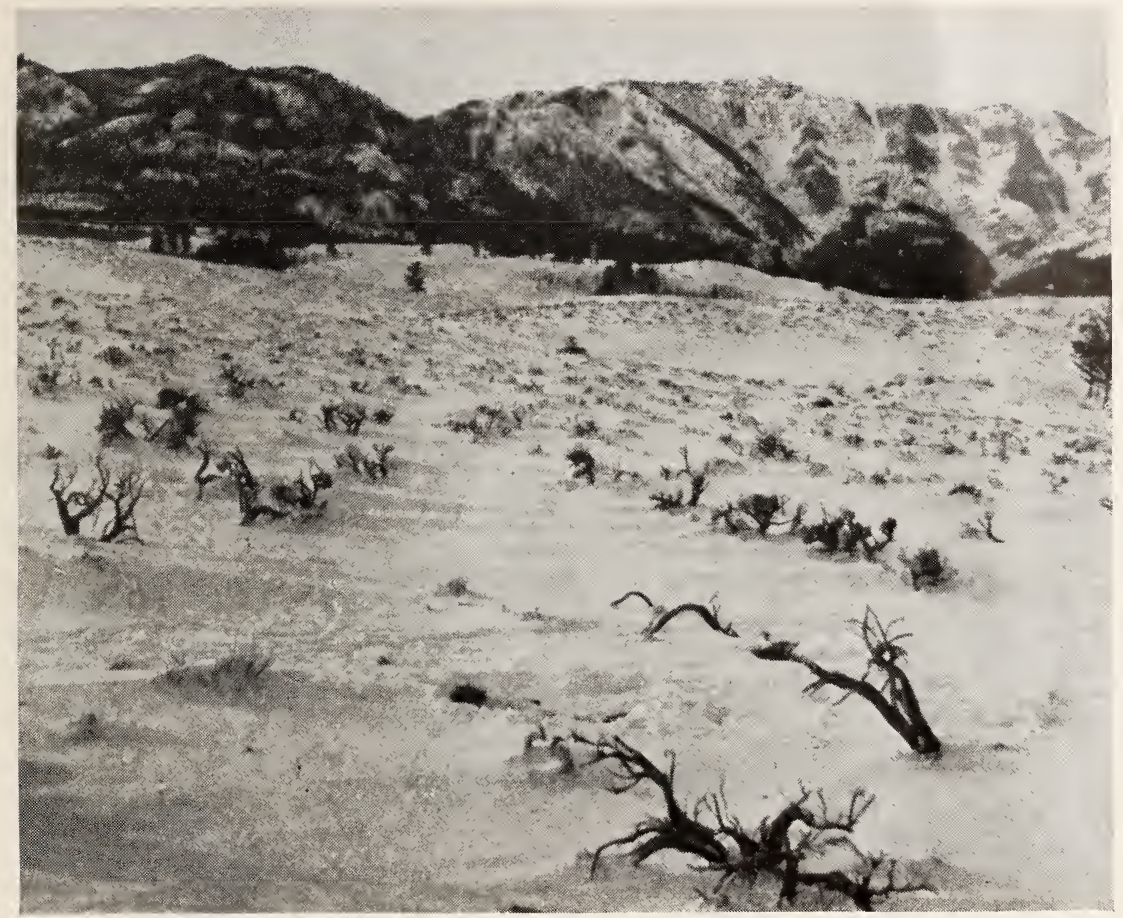

Figure 34. - MOST OF THE SAGEBRUSH IN THE PICTURE HAS BEEN KILLED BY OVERBROWSING. ANTELOPE HAD FED IN THE AREA ON THE SCANTY FOOD STILL TO BE FOUND.

Game Ranch Area, January 13, 1938. 


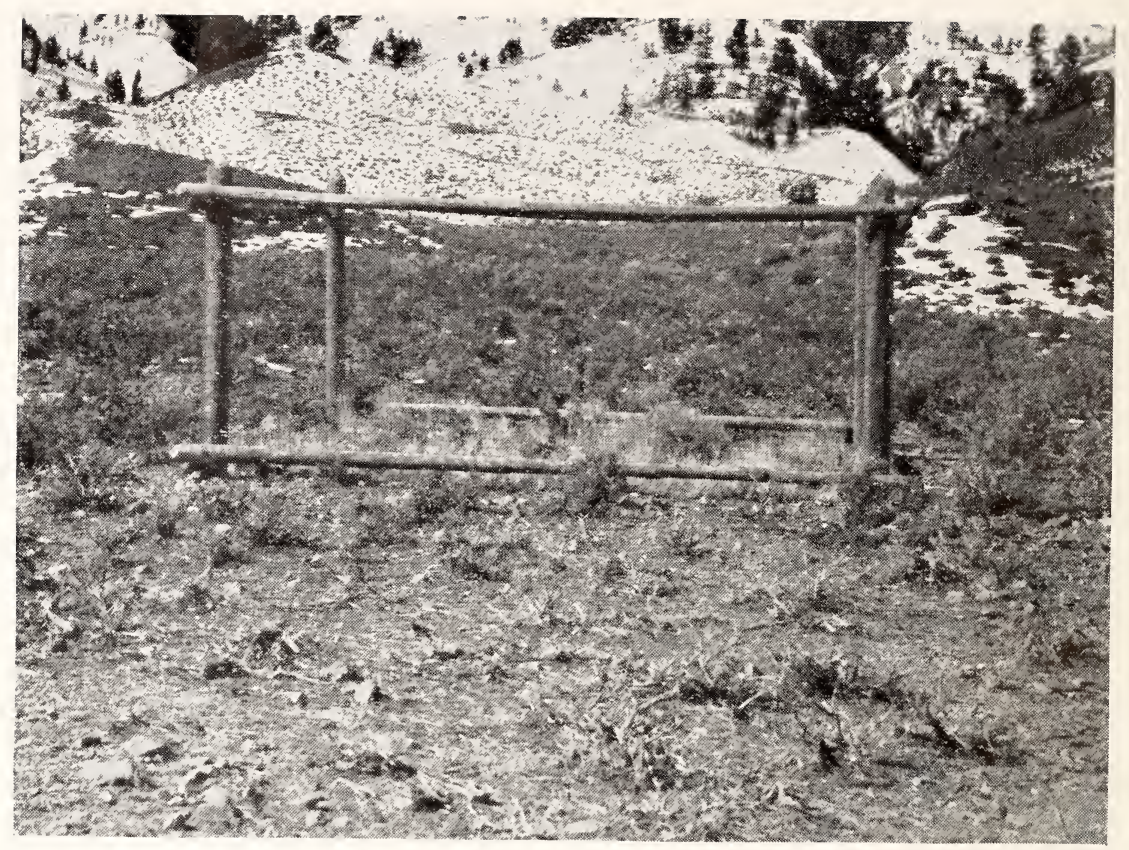

Figure 35. - ENCLOSURE PLOT AT THE GAME RANCH. THE BARE GROUND AND DYING SAGEBRUSH OUTSIDE SHOW HOW CLOSELY THE ELK AND ANTELOPE CLEANED THE RANGE.

Game Ranch, April 1938. 


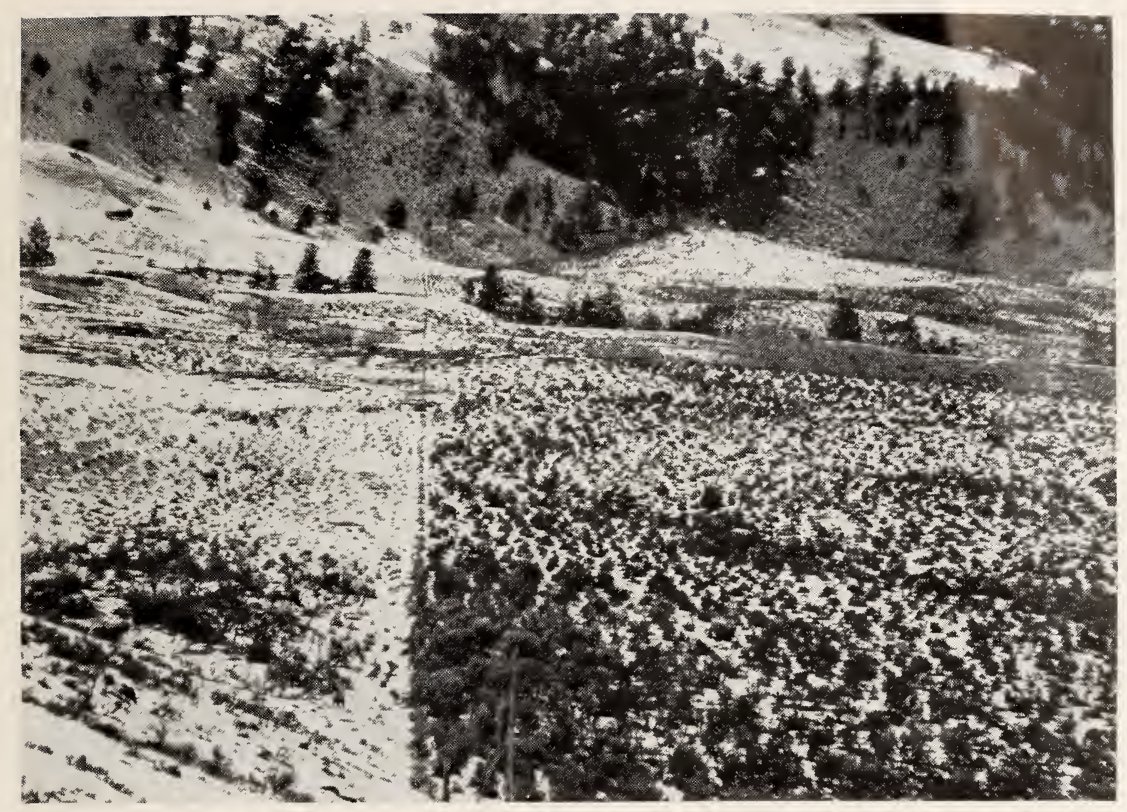

Figure 36. - THE VERTICAL LINE SHOWS THE POSITION OF A FORMER BOUNDARY FENCE.

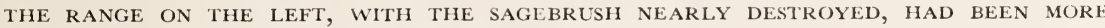
HEAVILY USED BY ANTELOPE PRIOR TO REMOVAL OF THE FENCE. 


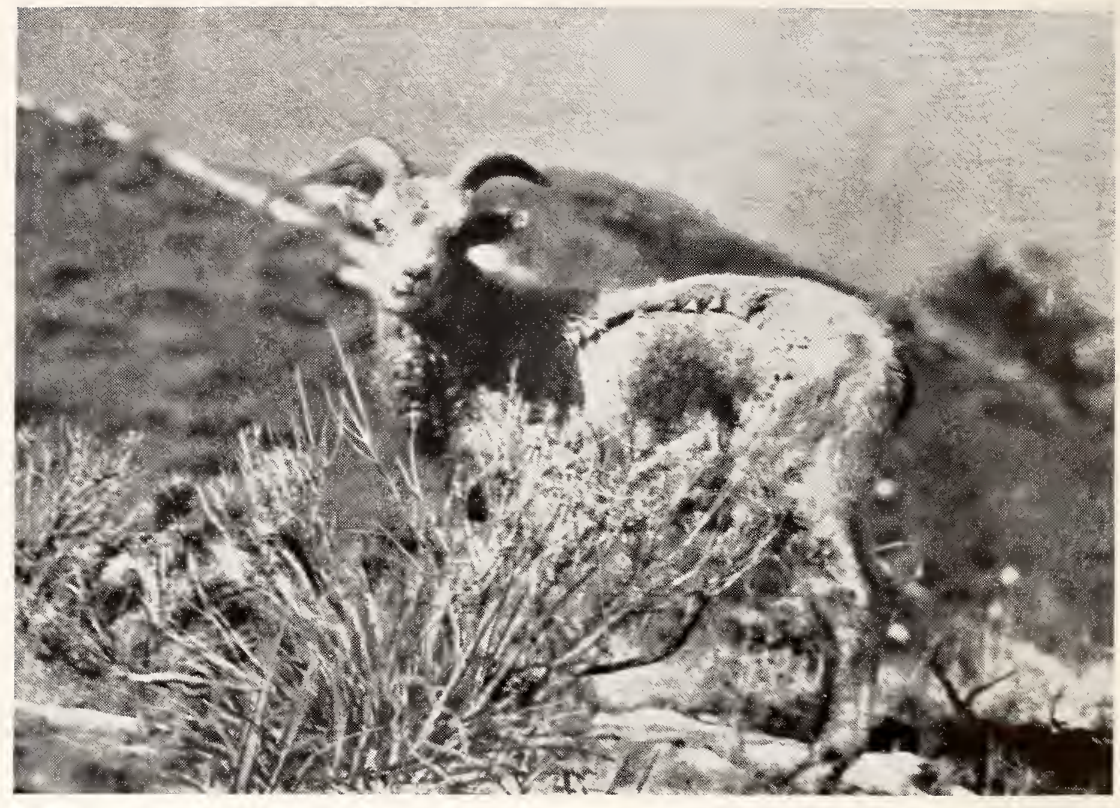

Figure 37. - AN ISOLATED YOUNG RAM A SHORT TIME BEFORE HE DIED. THE HEAVY INFESTATION OF SCAB MITES, CAUSING LOSS OF LONG HAIRS OVER SIDE OF THE BODY AND PARTS OF NeGk, was seen on Several young rams in the fall. Mount Everts, January 16, 1938. 


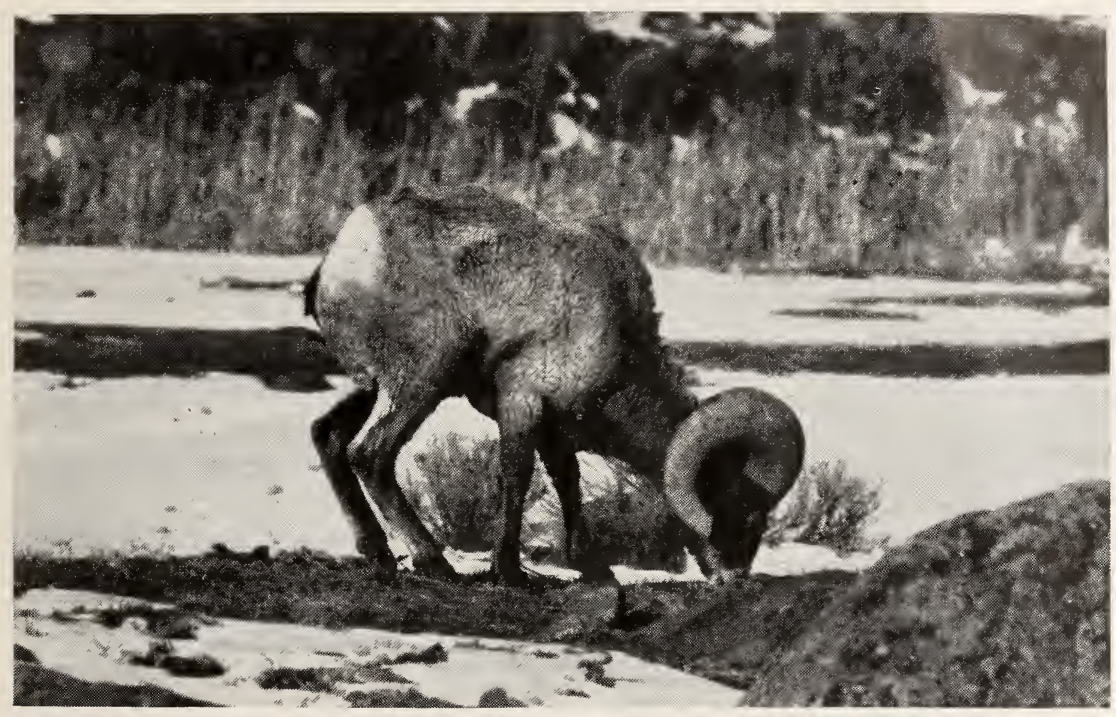

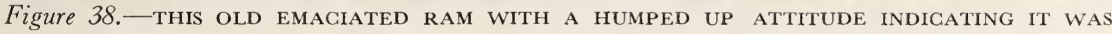
AILING WAS FOUND DEAD A FEW DAYS AFTER THIS PICTURE WAS TAKEN.

Gardiner River at base of Mount Everts, March 26, 1938.

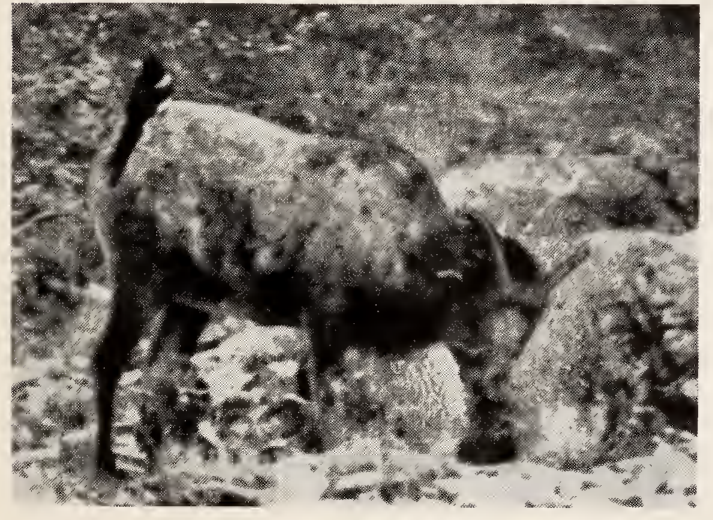

Figure 39.-A MAGPIE SITTING ON THE RUMP OF A EWE. MAGPIES WERE OFTEN SEEN ON BIGHORN PICKING ON VARIOUS PARTS OF THE BODY AS THOUGH FEEDING ON PARASITES.

Mount Everts, November 25, 1937. 


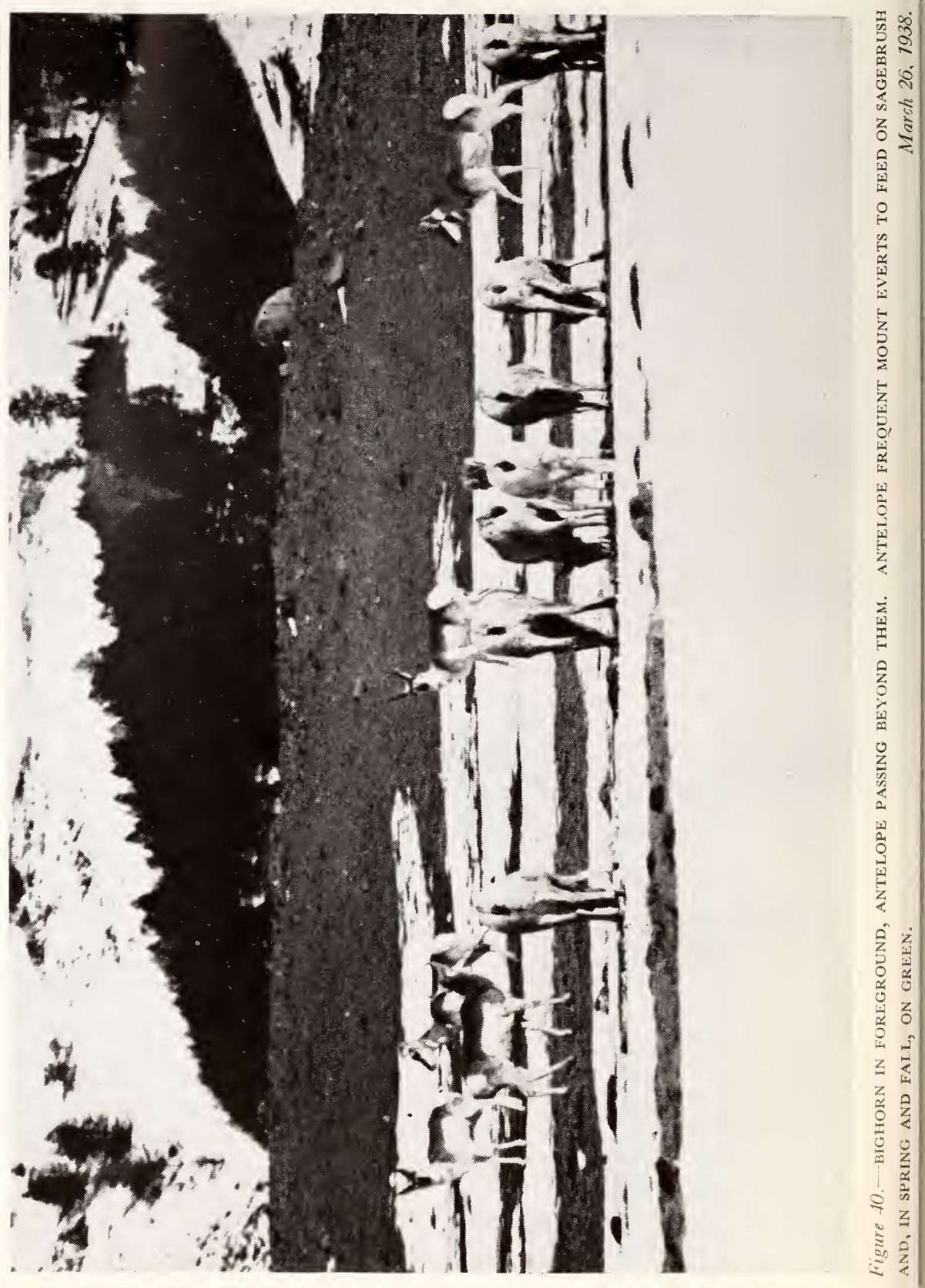




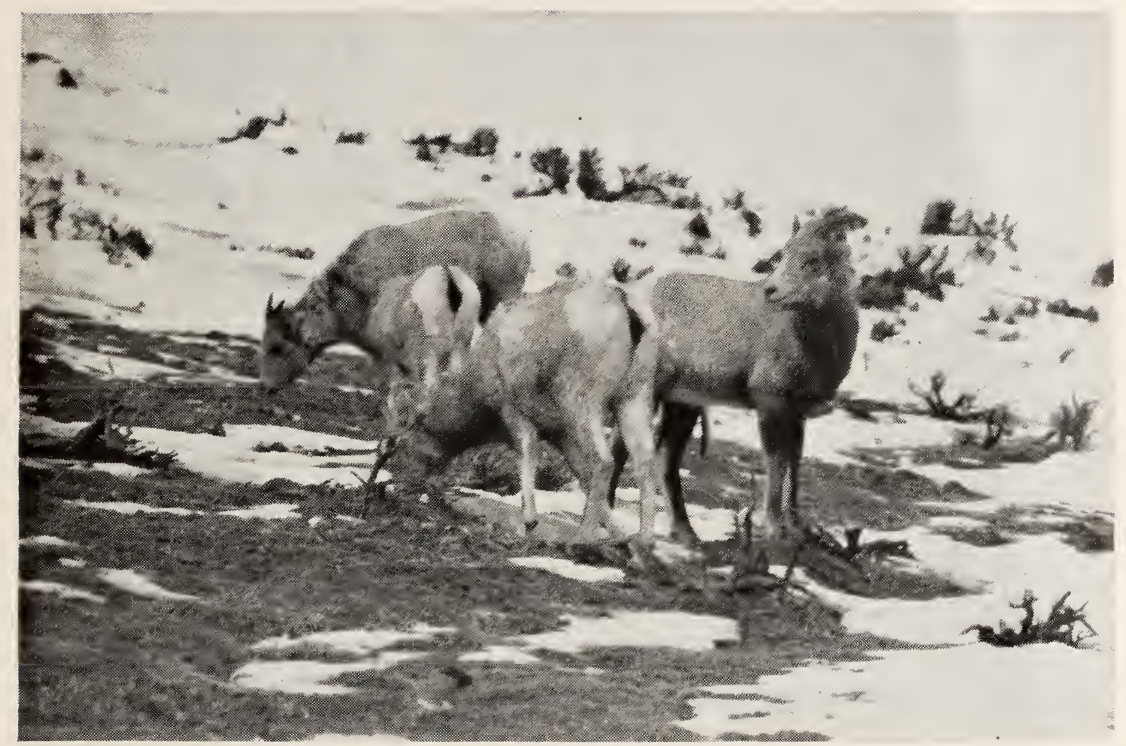

Figure 41.- BIGHORN FEEDING ON A RANGE THAT WAS CLOSELY GRAZED, MAINLY BY ELK. LOOSE DISCARDED SEED STEMS OF NEEDLE GRASS WERE THE GHIEF FOOD ITEMS.

Mount Everts, March 6, 1939. 


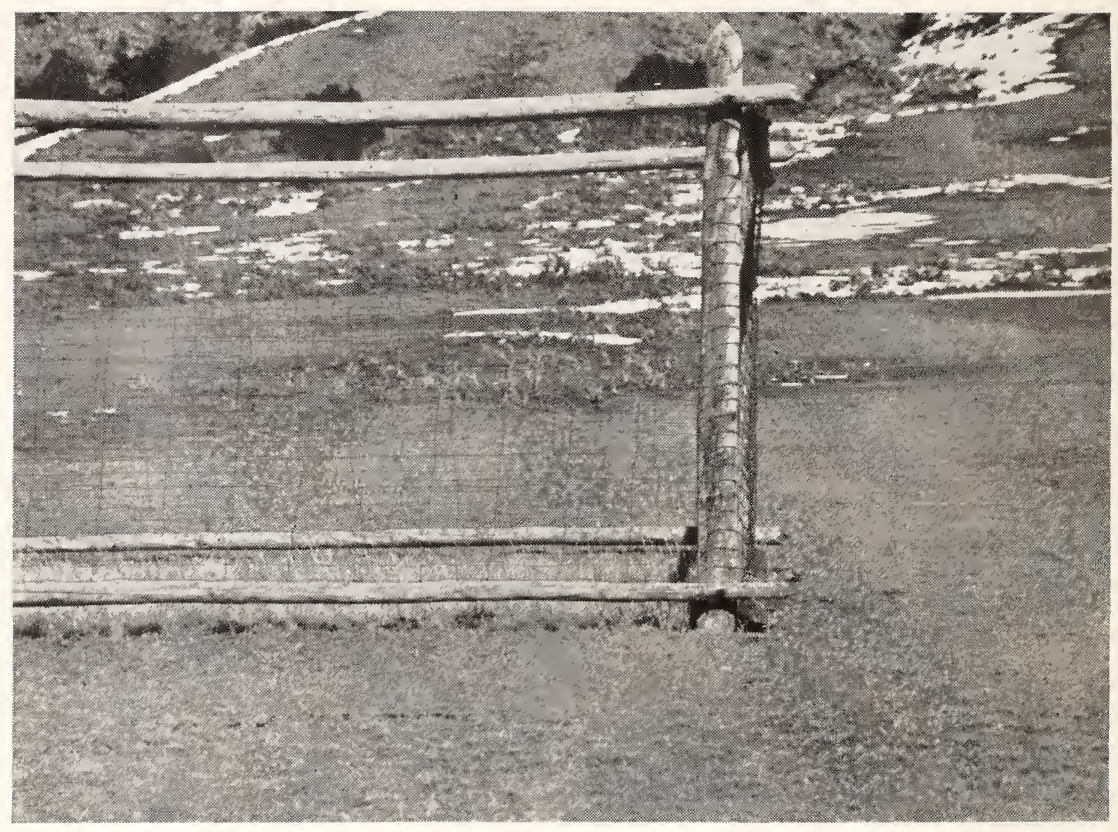

Figure 42.-PROTEGTED STUDY PLOT, SHOWING CONTRAST WITH UNPROTECTED RANGE CLOSELY GRAZED DURING THE WINTER OF 1937-38. Mount Everls, Af,ril 8, 1938 


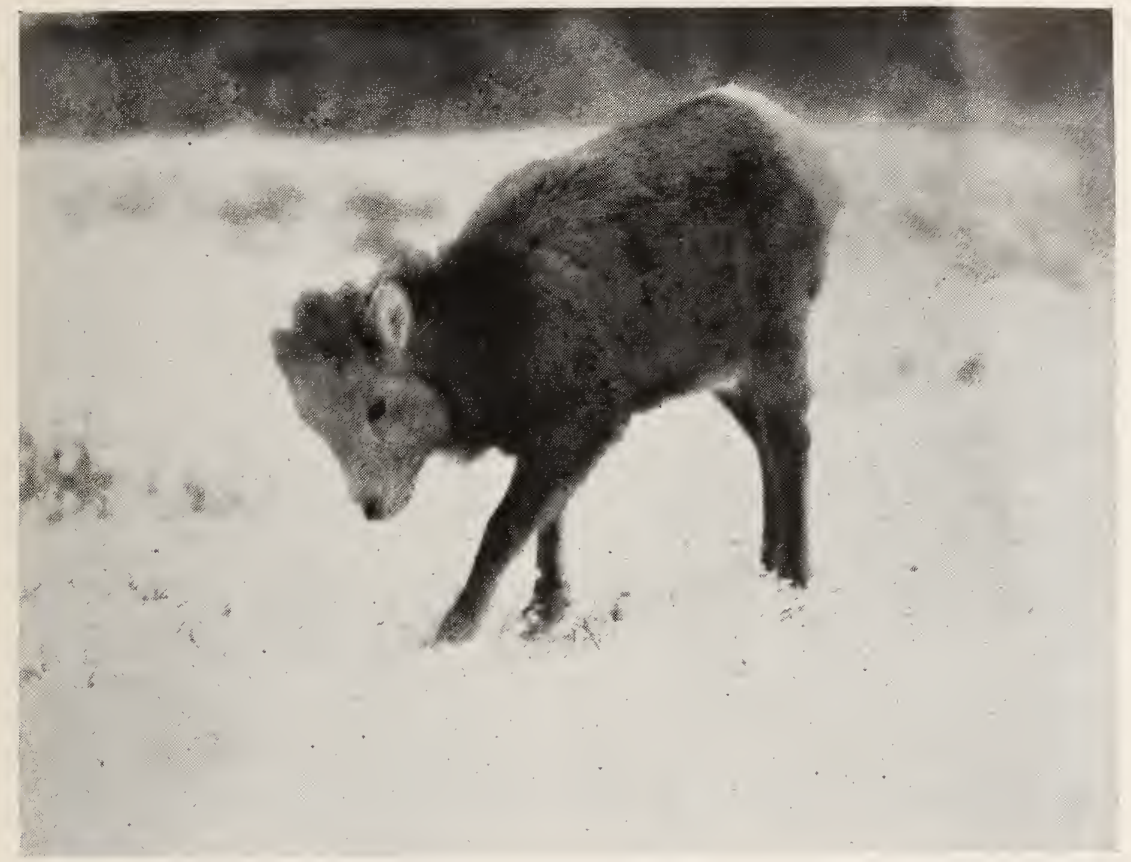

Figure 43. - A HEALTHY LAMB PAWING FOR SHORT RUSSIAN THISTLE. BIGHORN READILY PAWED THROUGH 14 INCHES OF SNOW. Mount Everts, February 9, 1938. 


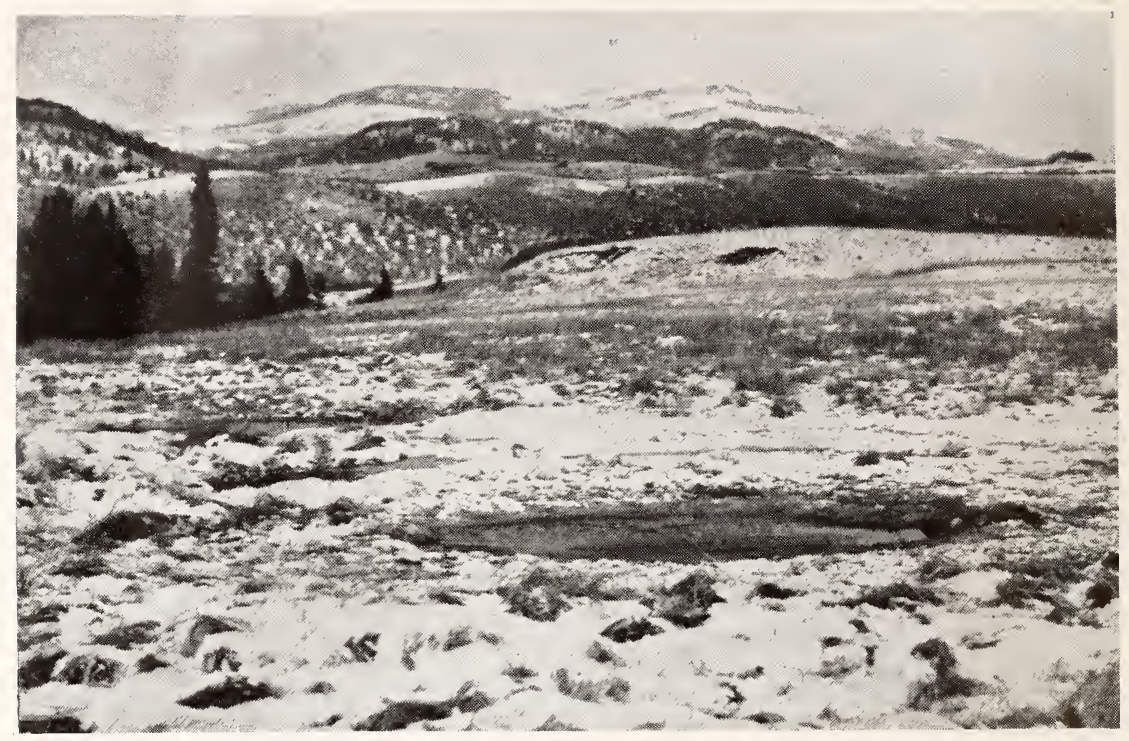

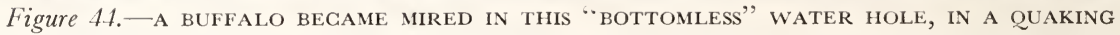
SEDGE BOG, AND WAS APPARENTLY DROWNED. GOYOTES FED ON PART OF THE CARCASS AND LATER A BEAR PULLED OUT THE REMAINDER. Horseshoe, November 1938. 


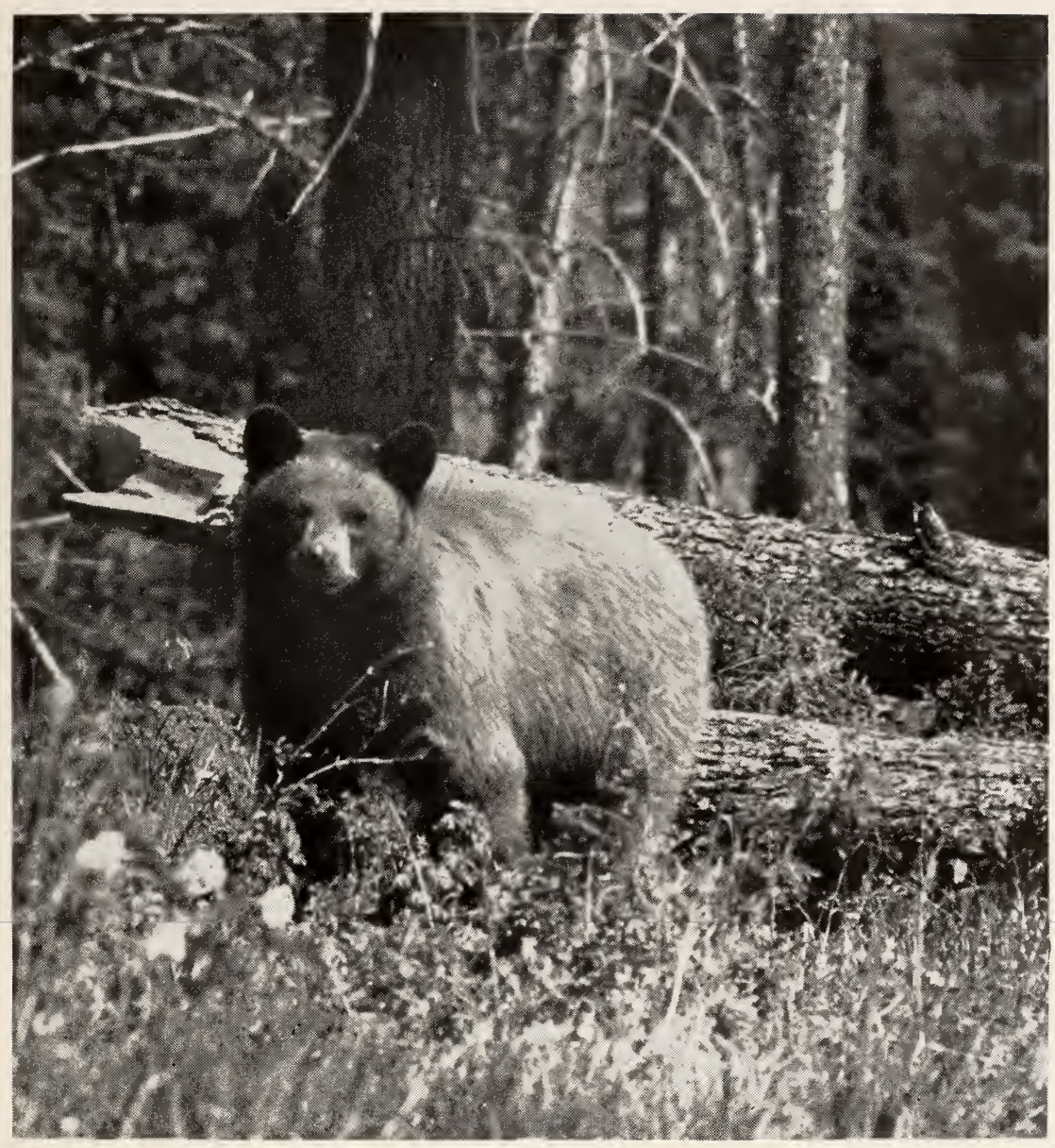

Figure 45.-THE BLACK BEAR IS PRIMARILY A VEGETARIAN BUT TAKES ANYTHING THAT COMES HiS WAY. OGGASIONALLY HE STUMBLES ON AN ELK GALF.

Tower Falls, Fune 10, 1938. 


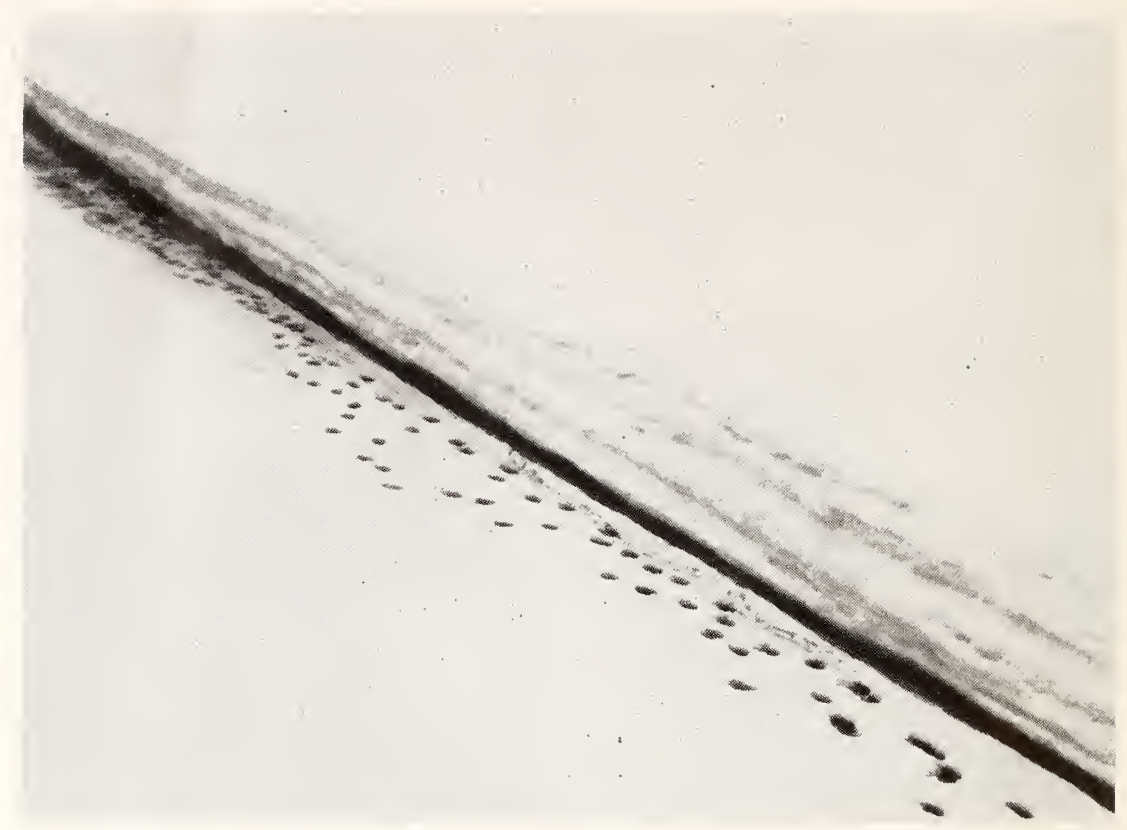

Figure 46.-TRACKS SHOW HOW COYOTES FOLLOWED ALONG A SNOW BANK, BORDERING A ROAD OPENED UP BY THE SNOW PLOW, HUNTING MICE WHICH COME OUT IN THE ROAD FROM UNDER THE SNOW.

Swan Lake Flat, April 14, 1938. 


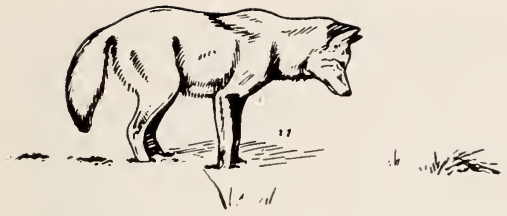

WATCHING

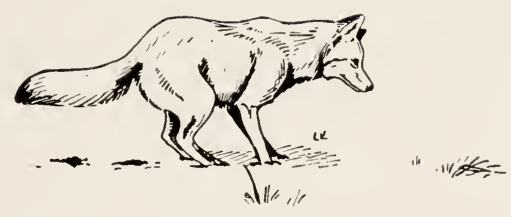

SOMETHING STIRRING!
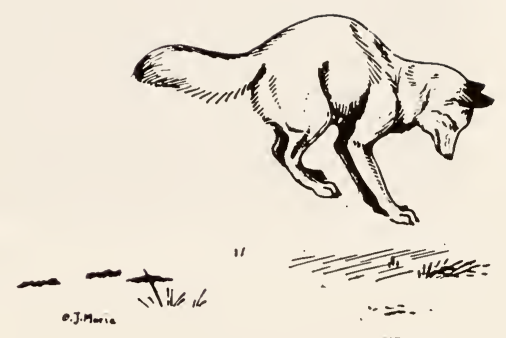

THE POUNCE

Figure 47.- TyPiCAL Attitudes of A Coyote CATChing a Mouse.

Sketched from life by 0 . 7. Murie. 


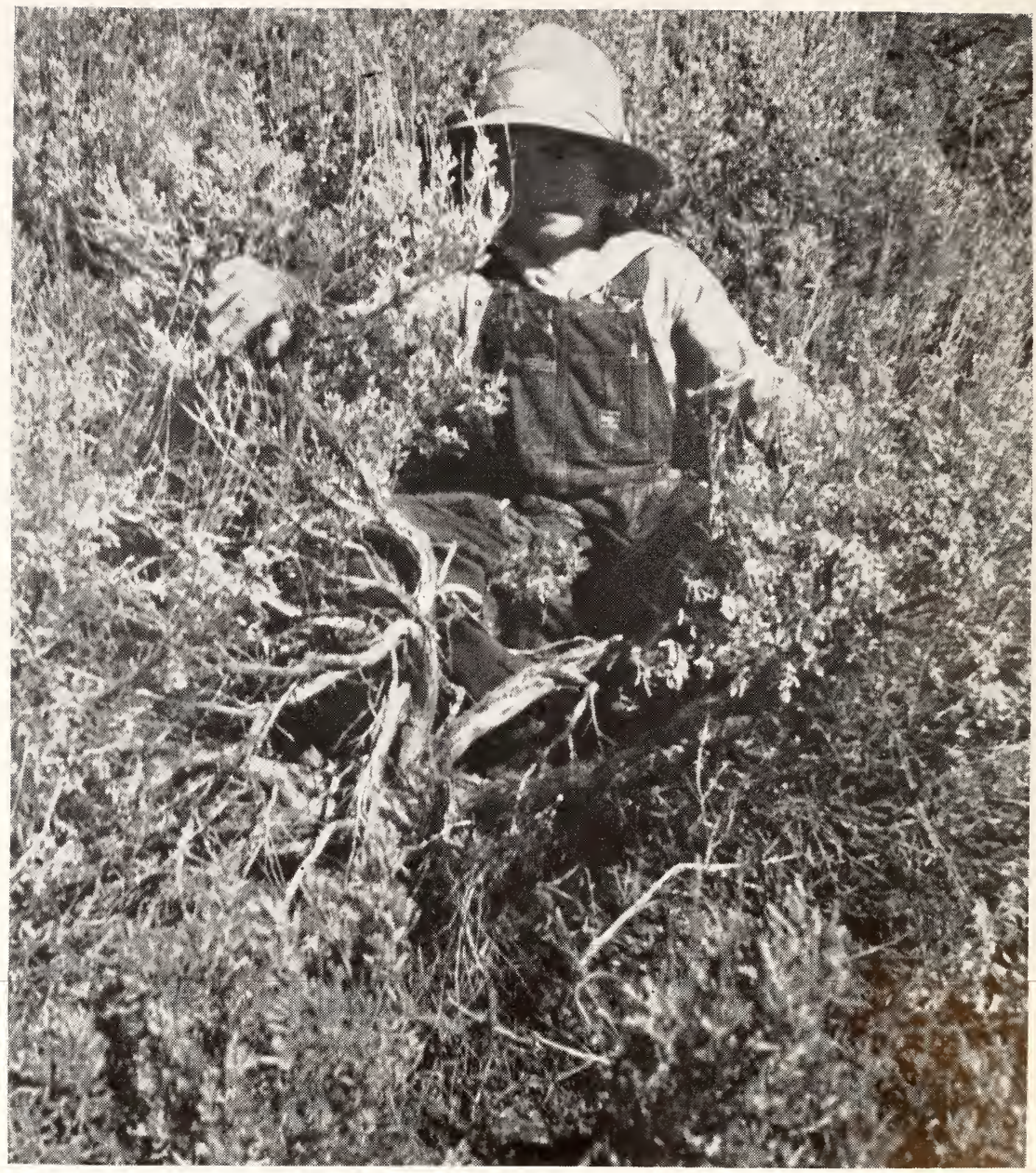

Figure 48.- SAgebrush KILled BY MOUSE GIRDling: PART OF A PATCH OF 600 SQUARE YARDS IN WHICH IT WAS ESTIMATED ONE-FOURTH OF THE SAGE HAD BEEN KILLED.

Across Lamar River from Buffalo Ranch, June 7, 1938. 


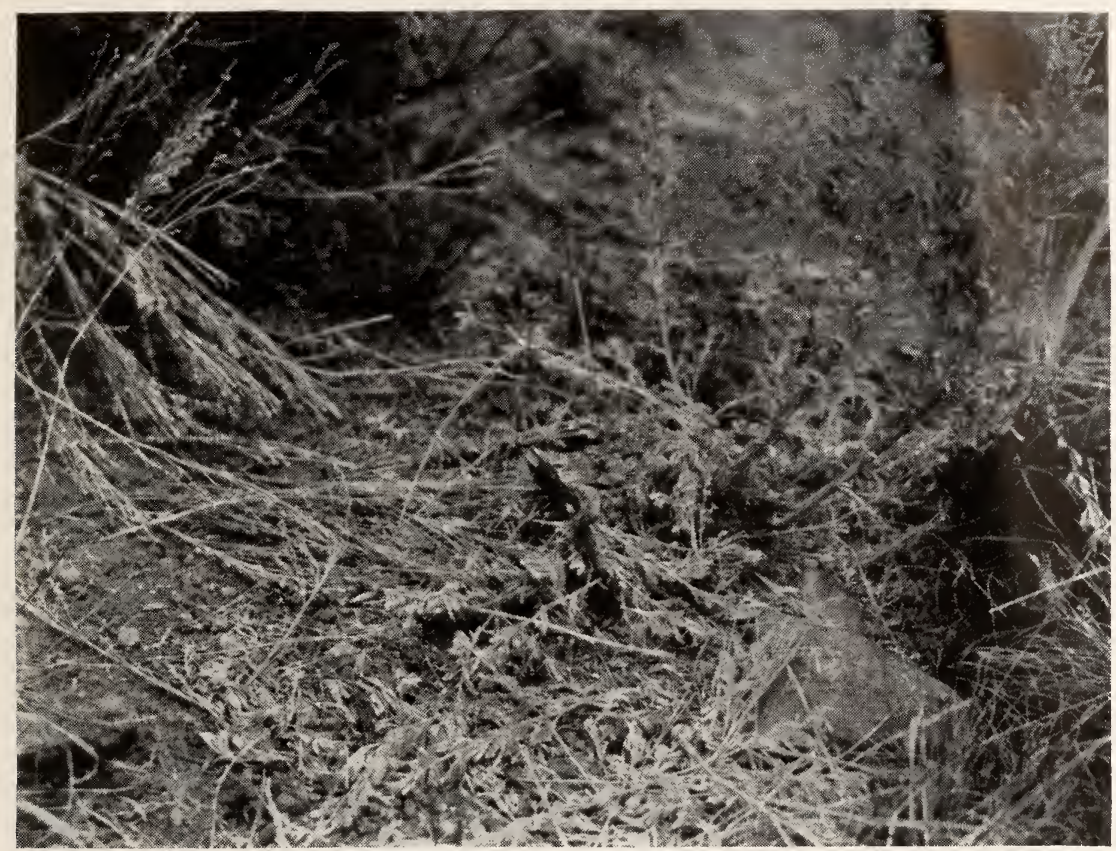

Figure 49. - SAGEBRUSH TRIMMED BY POCKET GOPHERS IN WINTER. MICE AND POCKET GOPHERS ARE THE LEADING ITEMS IN THE COYOTE DIET FOR A LARGE PART OF THE YEAR.

Blacktail Deer Creek, May 15, 1938. 


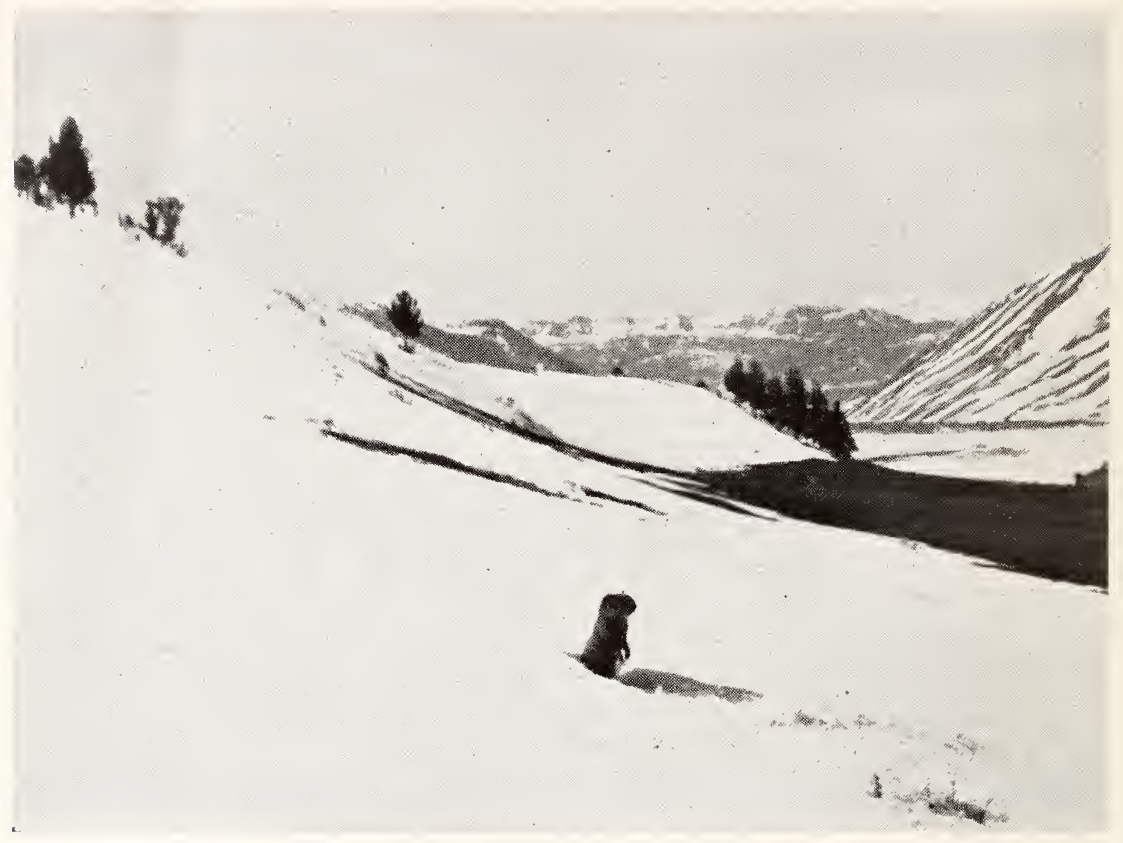

Figure 50.- GROUND SQUIRREL COMING FORTH IN EARLY SPRING. THIS ANIMAL CROSSED 40 YARDS OF SNOW TO FEED AT THE BARE AREA. AT SUGH TIMES GROUND SQUIRRELS ARE ESPECIALLY EXPOSED TO COYOTE ATTACK. Jackson Hole, Wyoming, April 1937. 


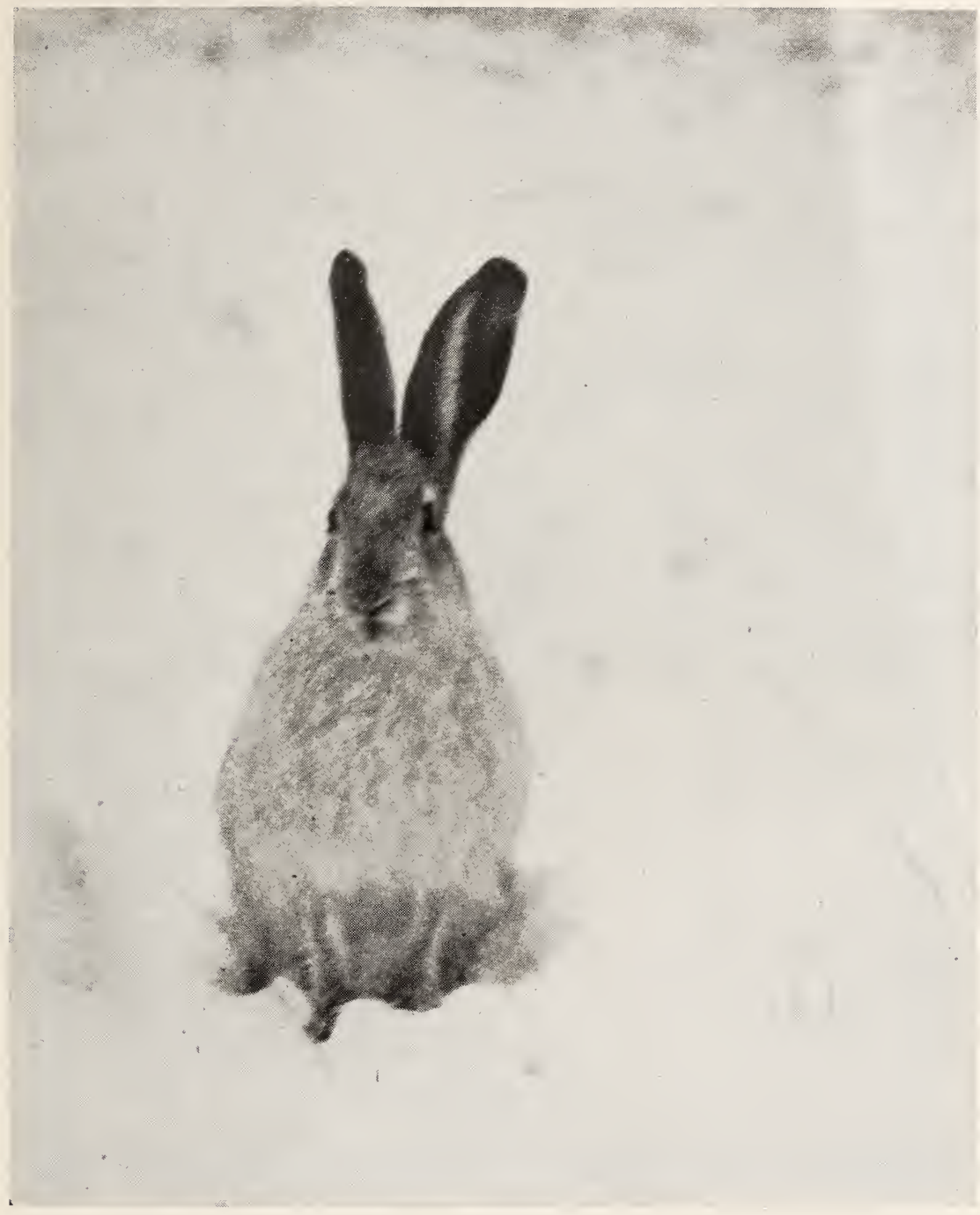

Figure 51.-THE JACKRABBIT IS OFTEN AN IMPORTANT COYOTE FOOD ITEM IN LOCALITIES WHERE IT IS ABUNDANT, BUT IN YEILLOWSTONE IT IS OF MINOR IMPORTANCE. Mammoth 1935. 


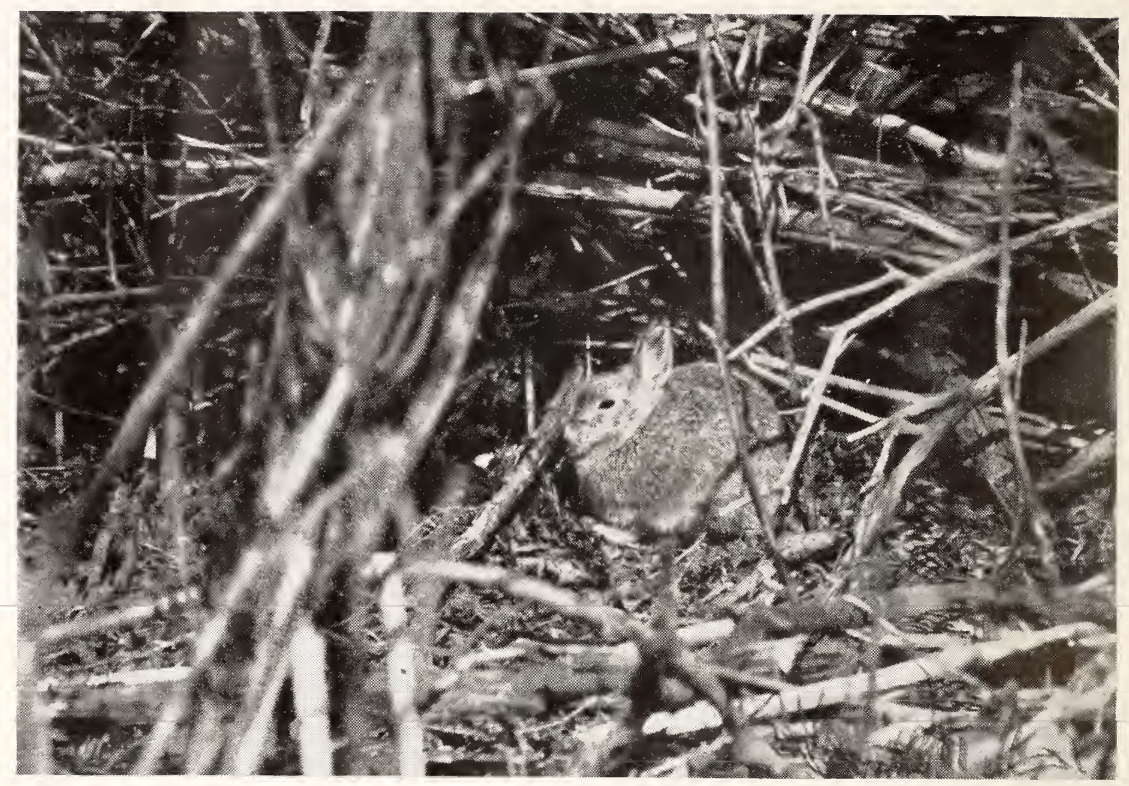

Figure 52. - A COTTONTAIL RABBIT WAS FOUND IN THIS SPOT ON TWO SUCCESSIVE DAYS. SEVERAL COYOTES WERE FEEDING ON AN ELK CARCASS AT THIS TIME ABOUT 10 YARDS AWAY. Gardiner Rizer, April 6, 1938. 


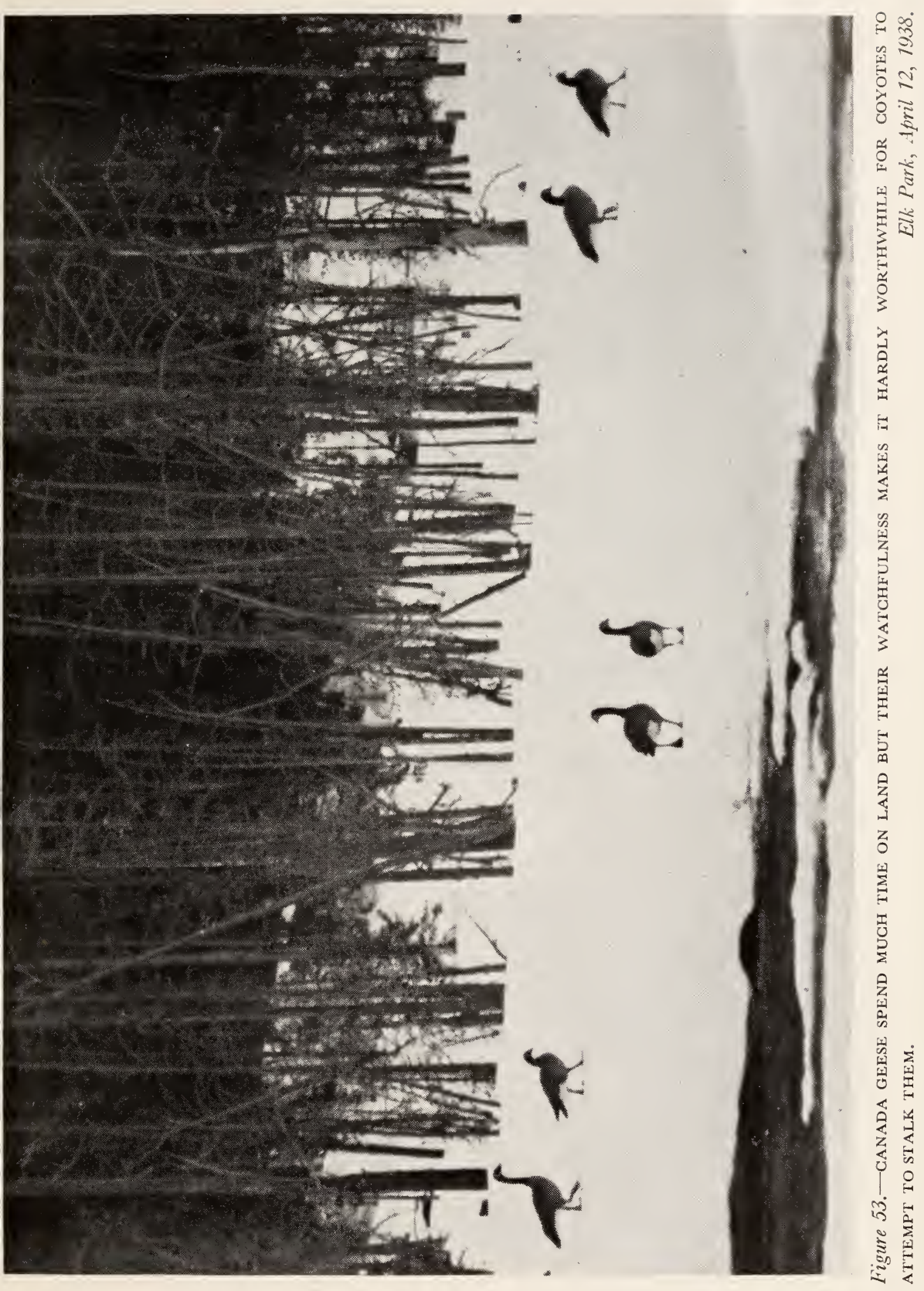




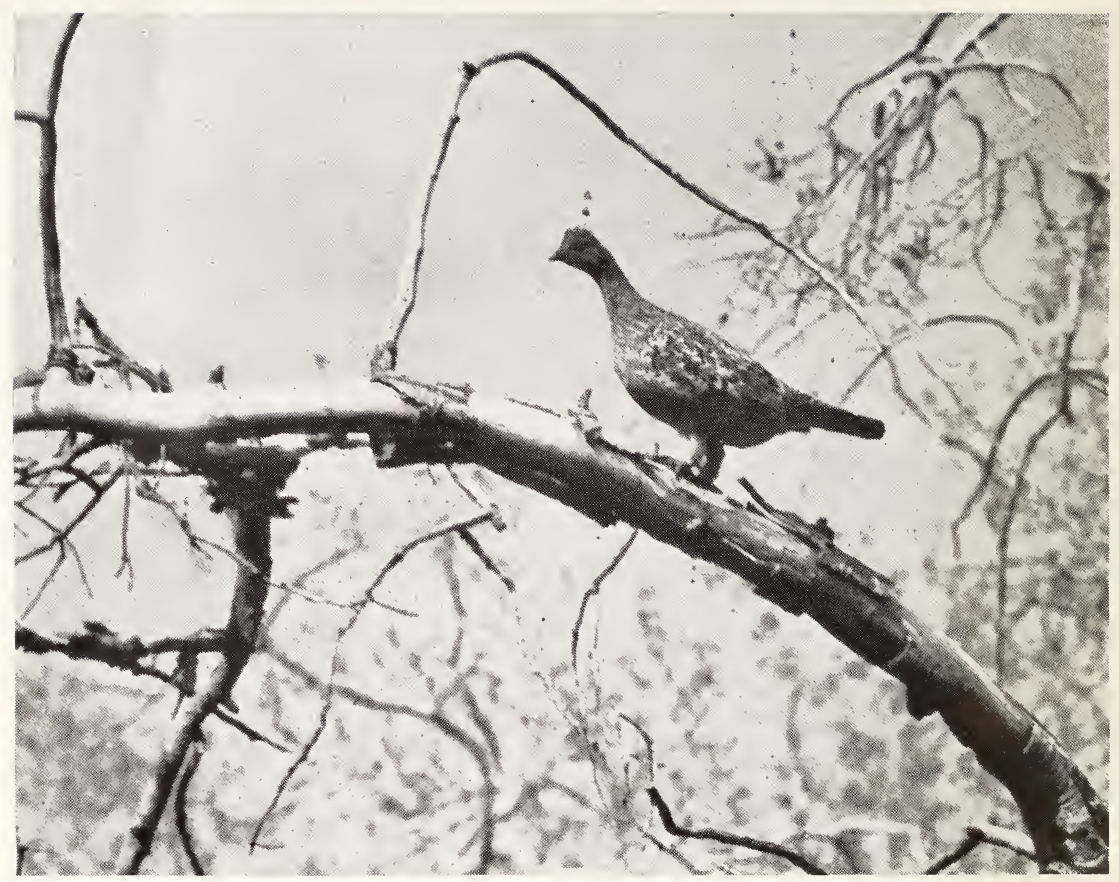

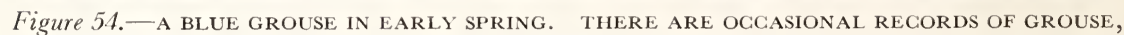
Killed by hitTing Wires, forming Garrion for coyotes. Teton National Forest, April 1936. 


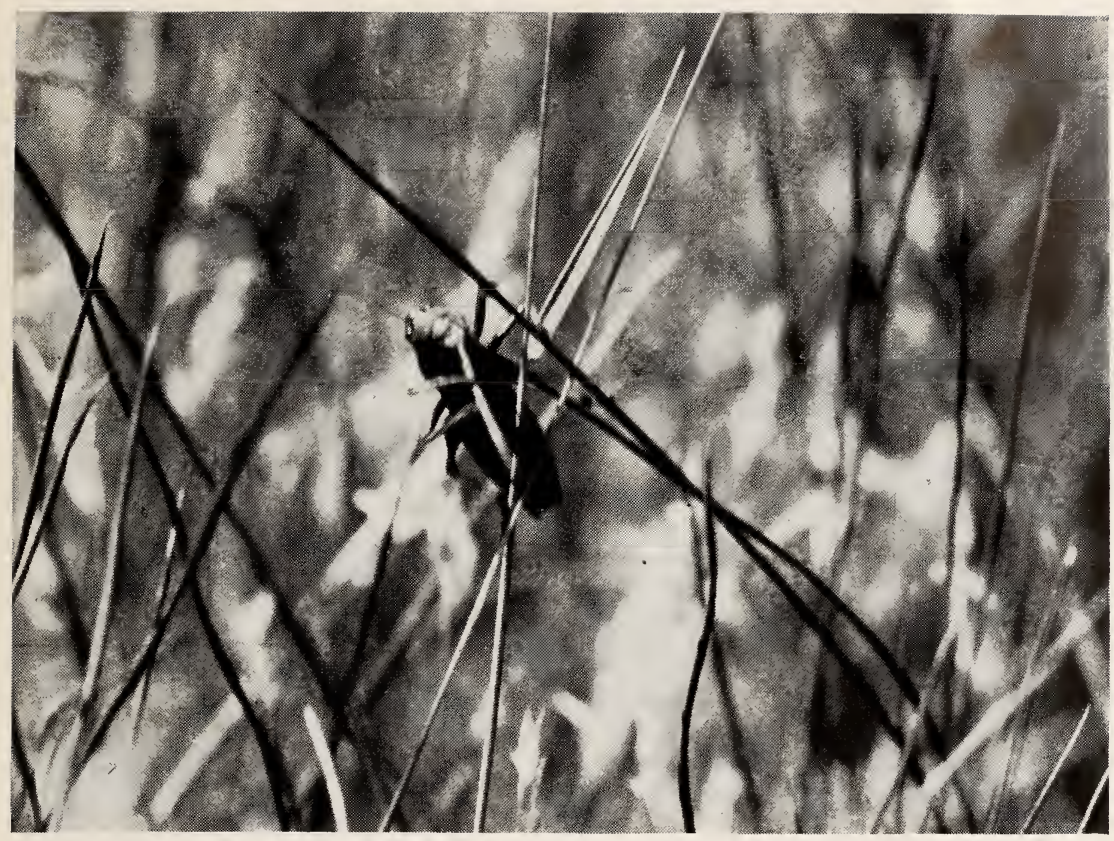

Figure 55.-MORMON CRICKET FEEDING ON RUSH. THESE, AS WELL AS GRASSHOPPERS, ARE RELISHED BY THE COYOTE. Horseshoe, July 6, 1938. 


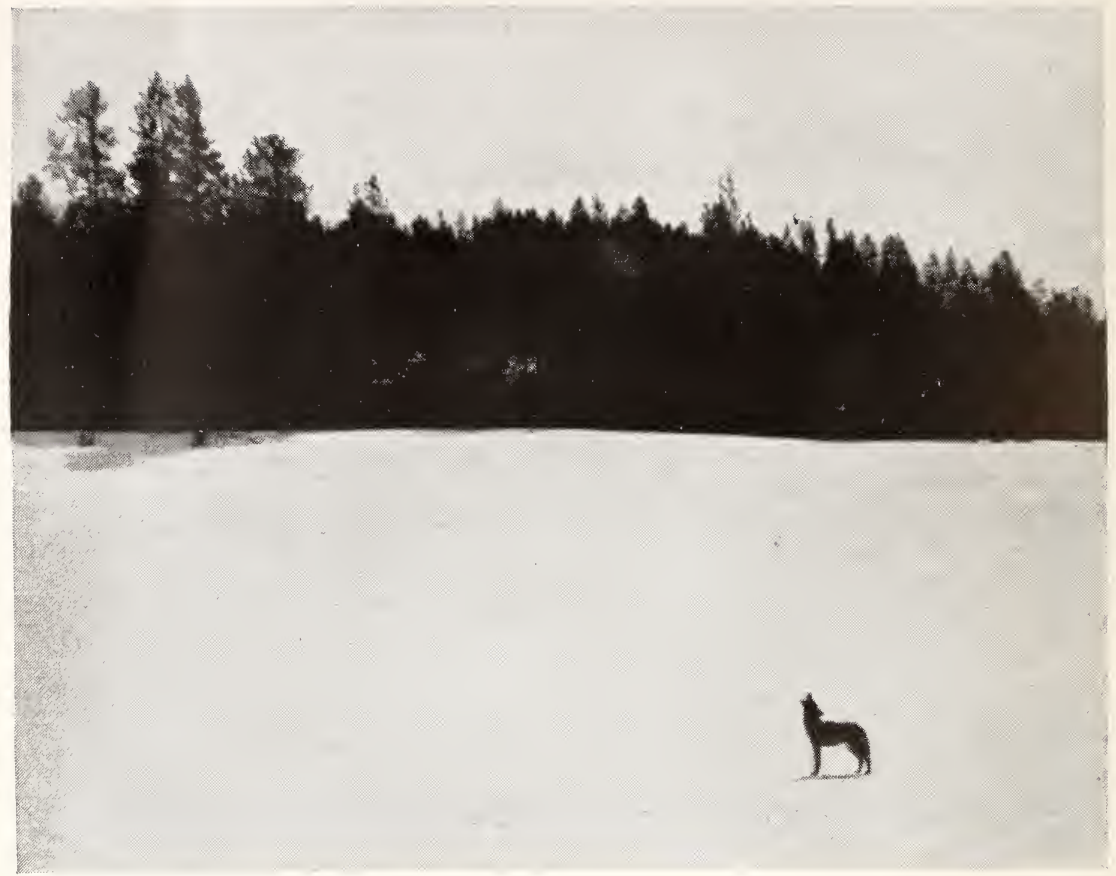

Figure 56.- COYOTE SONG.

Swan Lake Flat, April 14, 1938. 


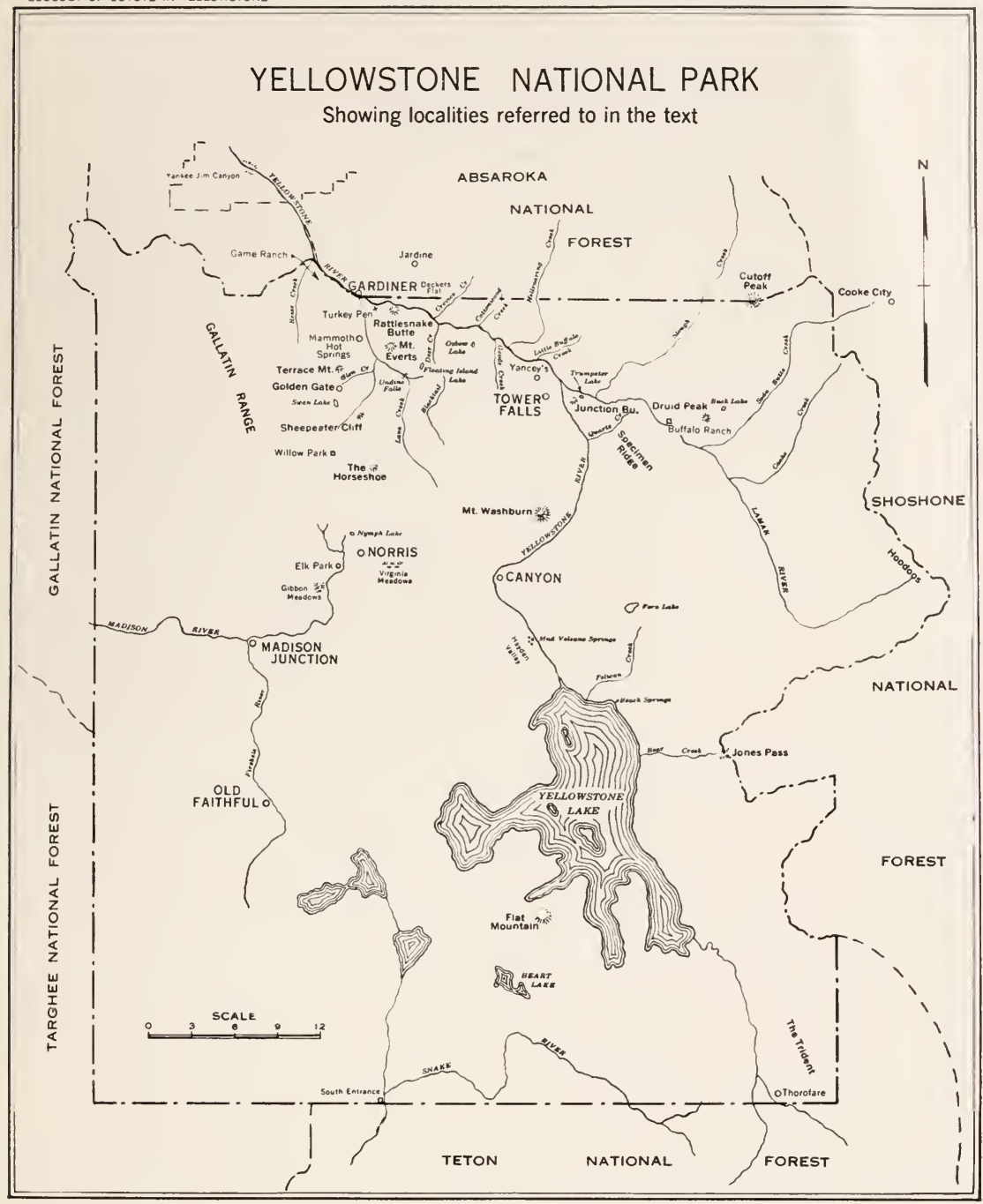





\section{N D E X}

Page

Absaroka National Forest

$1,19,20,46,147$

Anderson, Frank

Anderson, George S

Antelope

9-10,13, 14, 15, 115

Coyote relationships

100-101

Deaths

99-100

Diet .

$87-88,89$

Fawns

$90,91,92,93,94,95$

Fawn survival:

Season 1937

Season 1938

General condition of .

In relation to coyotes

$87-102,147$

Maternal protection

90-94

Relationships of bucks to does and fawns

Spring activities

Status of

Winter range

Arnold, Ben

Arnold, Marguerite L.

Bailey, Vernon .

Bat

Bear.

Black

Beaver

$12,126-127$

Benson, H. C

Bighorn

$10,14,22,89,103-116$

Coyote relationships

113-114

Deaths

106-107

Distribution and numbers

103-104

General concition of

104-106

In relation to coyotes

103-116, 147

Lamb-ewe relationships

Lamb survival

1936 season

1937 season

108-110

1938 season

110-112

Magpie relationships

112-113

Status of .

114-116

Birds, other remains

In relation to coyotes

129-142, 146

Bison .

Bobcat

Botfly, in coyote diet .

Buffalo. 
Behavior of coyotes . ........................ 30-32

Chipmunks................................... 127-128

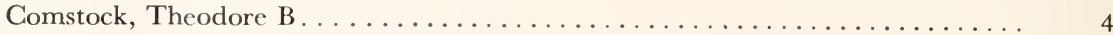

Conclusions. . . . . . . . . . . . . . . . . . . . . . . . . . . 146-148

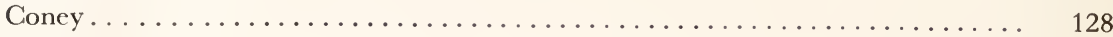

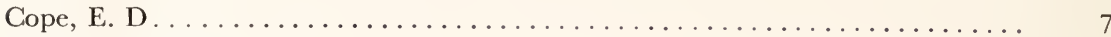

Cottam, Clarence C.................................. 138

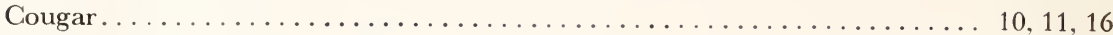

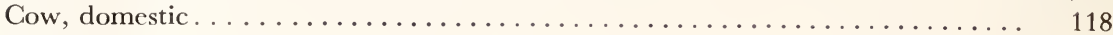

Coyotes:

Antelopes in relation to . . . . . . . . . . . . . . . . . 87-102

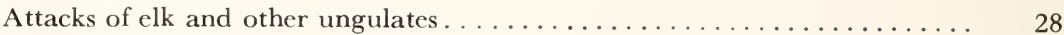

Bighorn relationships . . . . . . . . . . . . . . . . . . . . 113-114

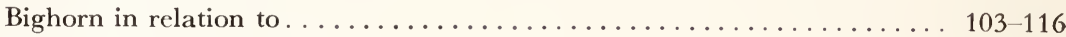

Birds in relation to . . . . . . . . . . . . . . . . . . . . . . . . 129-142

Carcass fragments in diet . . . . . . . . . . . . . . . . . . 118-119

Deer behavior . . . . . . . . . . . . . . . . . . . . 82-84

Diet:

Antlers................................... 119

Bone. . . . . . . . . . . . . . . . . . . . . . . . . 118-119

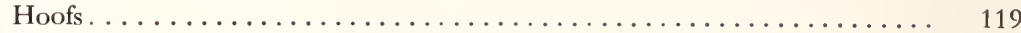

Disease . . . . . . . . . . . . . . . . . . . . 24-28

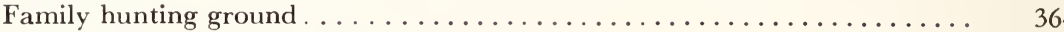

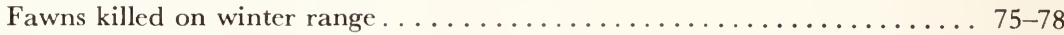

Food ....................... 40-45, 46-51,58-59, 120

Habits. . . . . . . . . . . . . . . . . . . . . . . . 30-39

Method of hunting fawns. . . . . . . . . . . . . . $78-80$

In relation to mule deer $\ldots \ldots \ldots \ldots \ldots \ldots \ldots \ldots \ldots \ldots \ldots \ldots$

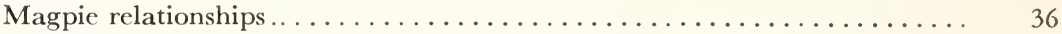

Miscellaneous items of diet . . . . . . . . . . . . . . . . 143-145

Mortality due to porcupine quills . . . . . . . . . . . . . . . . . 28

Mortality and natural controls . . . . . . . . . . . . . . . . . . . . . 20-29

Movements out of park ......................... 18-20

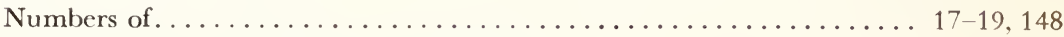

Predation correlated with range conditions . . . . . . . . . . . 80-82

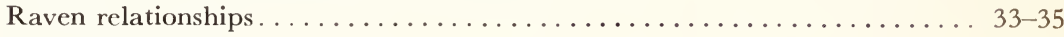

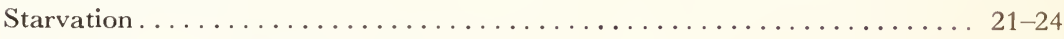

Starvation as a population control ..................... 24

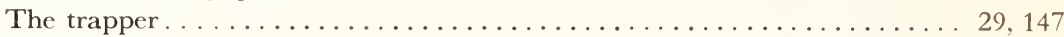

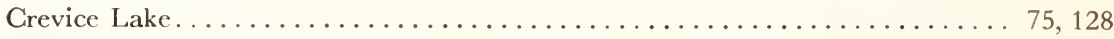

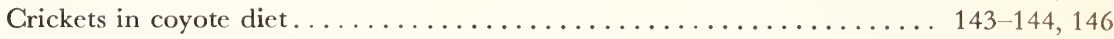

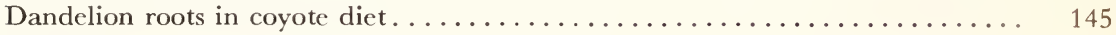

Deaths:

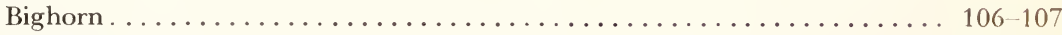

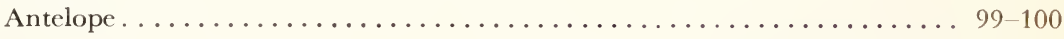

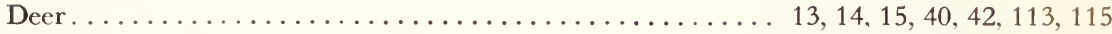

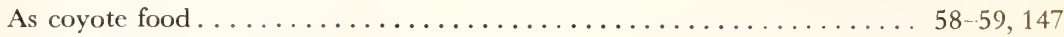

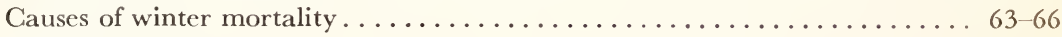

Coyote behavior . . . . . . . . . . . . . . . . . . . . . 82-84

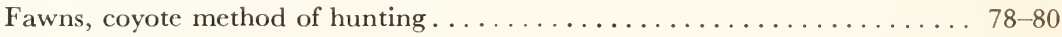

Fawns killed by coyotes on winter range . . . . . . . . . . 75-78 
Deer-Continued.

Fawns, loss of . . . . . . . . . . . .

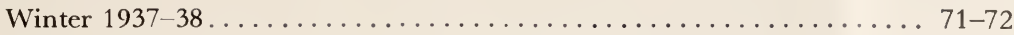

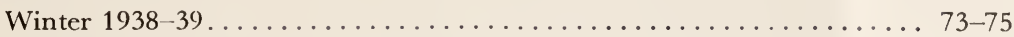

Fawn mortality correlated with winter range . . . . . . . . . . $72-73$

Fawn mortality higher than doe mortality . . . . . . . . . . . 72

Fawn survival ................................. 66-70

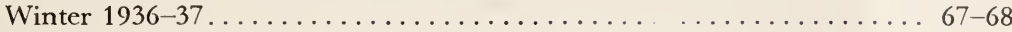

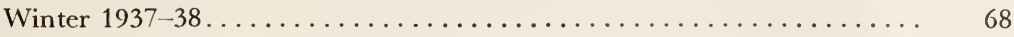

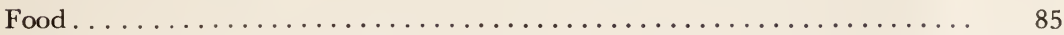

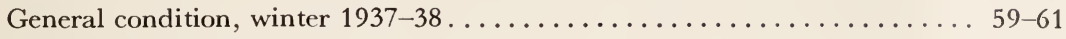

Mortality by months . . . . . . . . . . . . . . . . . . . 62-63

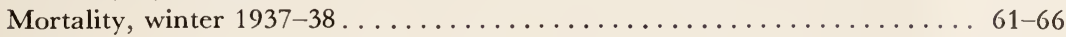

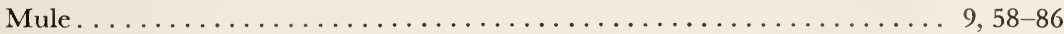

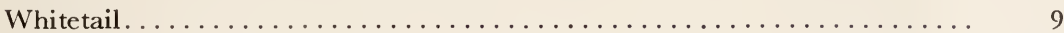

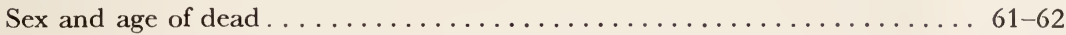

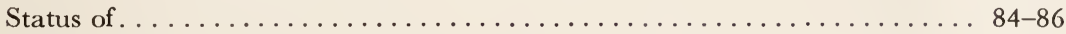

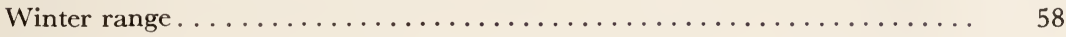

Diet:

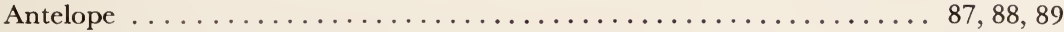

Carcass fragments in coyote . . . . . . . . . . . . . . . . . 118-119

Botfly in coyote diet. . . . . . . . . . . . . . . . . . . . . . 145

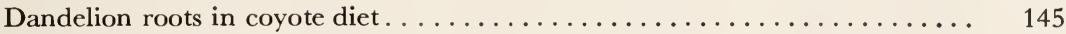

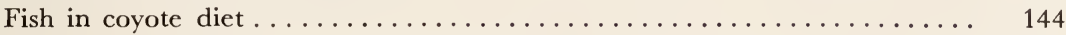

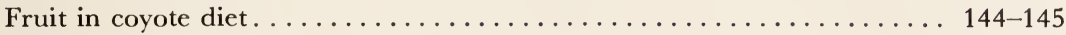

Grass in coyote $\operatorname{diet} \ldots \ldots \ldots \ldots \ldots \ldots \ldots \ldots \ldots \ldots \ldots \ldots \ldots \ldots \ldots \ldots$

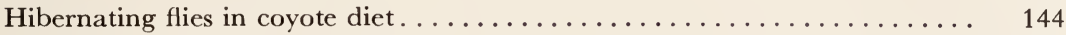

June beetles in coyote diet. . . . . . . . . . . . . . . . . . . . 144

Mushrooms in coyote $\operatorname{diet} \ldots \ldots \ldots \ldots \ldots \ldots \ldots \ldots \ldots \ldots \ldots \ldots \ldots$

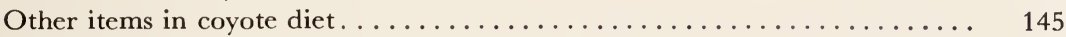

Pine nuts in coyote diet. . . . . . . . . . . . . . . . . . . . 144

Snails in coyote diet. . . . . . . . . . . . . . . . . . . . . 144

Snakes in coyote diet. . . . . . . . . . . . . . . . . . . . 144

Vegetable matter in coyote diet. . . . . . . . . . . . . . . . . 144-145

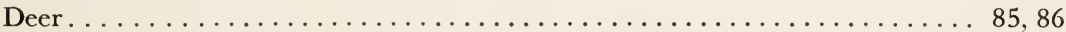

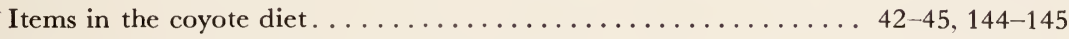

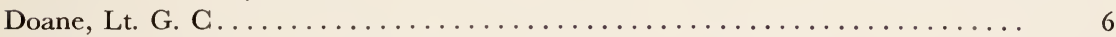

Droppings, coyote, examination of . . . . . . . . . . . . . . . . 40-45, $47,59,87,94,120,122-131,133,135,140,141,143-147$

Ducks . 129-132

American merganser, Barrow's golden-eye, blue-winged teal, gadwall, greenwinged teal, harlequin, mallard

As coyote food

$8,12,13,14,19,20,28,40,42,62,86,89,113,115$

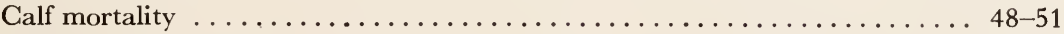

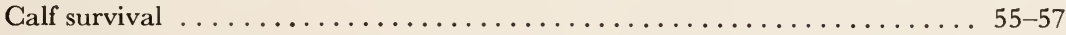

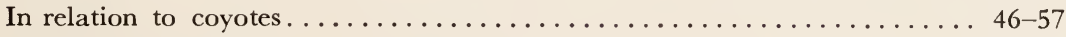

Maternal protection . . . . . . . . . . . . . . . . . . . . $51-55$

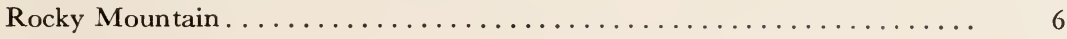

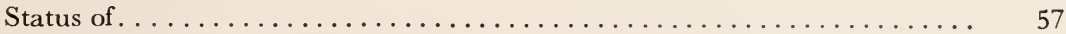

Elliott, Albert E. . . . . . . . . . . . . . . . . . . . . . . 130

Erwin, James B. . . . . . . . . . . . . . . . . . . . . . . . . 14

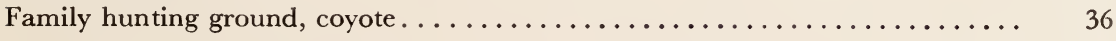


Antelope $90,91,92,93,94,95$

Coyote method of hunting .

. 78-80

Killed by coyotes on winter range

Loss of, winter 1937-38, 1938-39

Mortality correlated with winter range conditions . . . . . . . . . . $72-73$

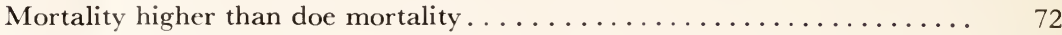

Survival, antelope. . . . . . . . . . . . . . . . . . . . . . . 94-98

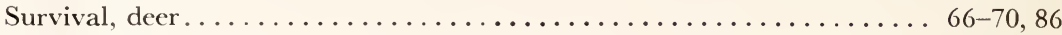

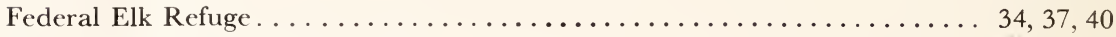

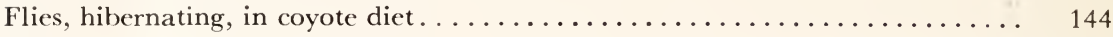

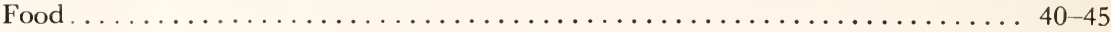

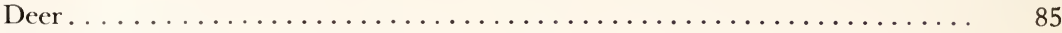

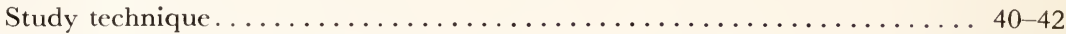

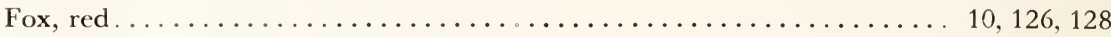

Fruit in coyote diet. . . . . . . . . . . . . . . . . . . . . . 144-145

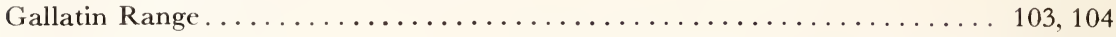

Game Ranch Range..........68, 71, 72, 73, 74, 85, 89, 95, 96, 97, 99, 118, 127

Gammill, Walter. . . . . . . . . . . . . . . . . . . . . . 137

Gardiner........... 17, 18, 19, 20,46, 58, 61, 66, 77, 95, 96, 98, 101, 103, 105

Gardiner River......... 68, 70, 72, 73, 74, 82, 83, 85, 86, 105, 106, 126, 127, 132

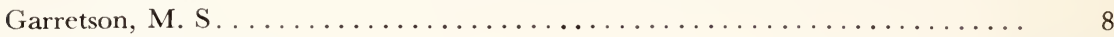

George Reserve, Mich. . . . . . . . . . . . . . . . . . . . . . 126, 128

Gibbon Meadows...................... 36, 40, 123, 128, 131, 143

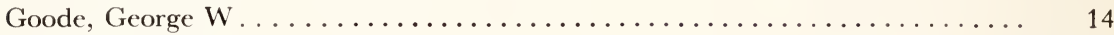

Goose, Canada. . . . . . . . . . . . . . . . . . . . . . . . . . 132-134

Gopher, Pocket. ............................. 122-124, 146

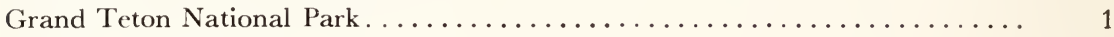

Grass in coyote diet. . . . . . . . . . . . . . . . . . . . . . . . . . 144

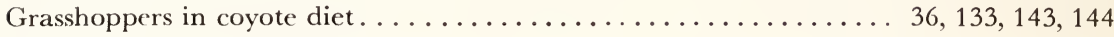

Gray, Mrs. Margaret................................ 23

Greer, J. L. . . . . . . . . . . . . . . . . . . . . . . . . . 87

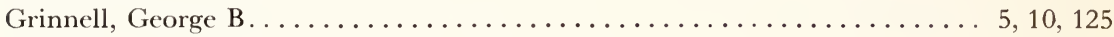

Grouse:

Richardson . . . ........................... 140-141

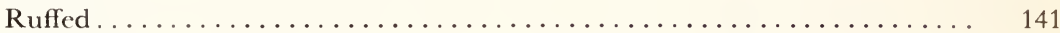

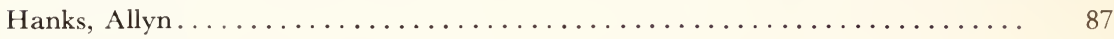

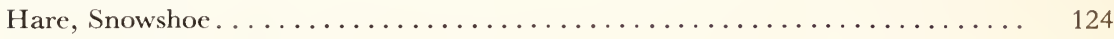

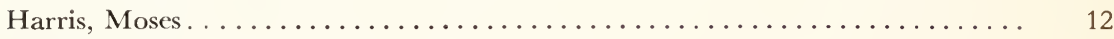

Hayden, F. V . . .............................. 4

Hayden Valley........................ 39, 40, 46, 50, 89, 142

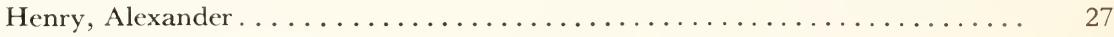

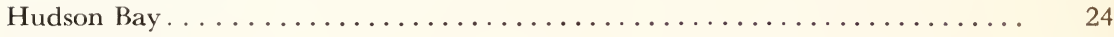

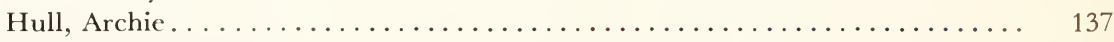

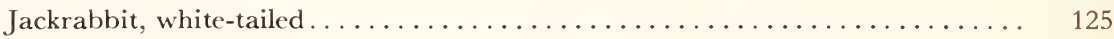

Insects in coyote diet. . . . . . . . . . . . . . . . . . . . 143-144, 146

Jackson Hole, Wyo.... 1, 18, 27, 34, 37, 107, 120, 126, 128, 130, 134, 136, 139, 140, 144

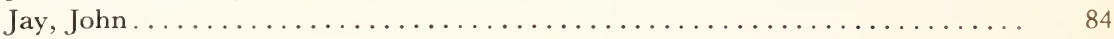

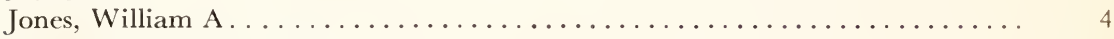

June beetles in coyote diet. . . . . . . . . . . . . . . . . . . . . . . 144

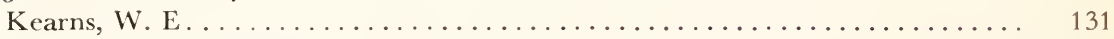

Lamb-ewe relationships. . . . . . . . . . . . . . . . . . . . . . . 112

Lamb survival, 1936, 1937, 1938 seasons . . . . . . . . . . . . . . . . 107-112

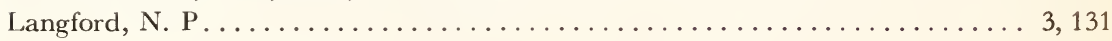


Livingston, Mont

Miscellaneous items of diet, coyote

Mouse:

Deer.

Field

Jumping

Mushrooms in coyote diet.

Necrotic stomatitis, deer.

Oberhansley, Frank R

Otter.

Pierrepont, Edward

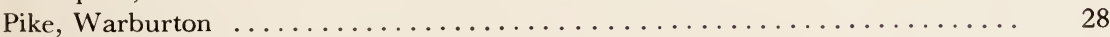

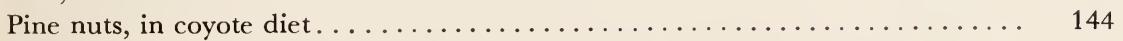

Play, coyote................................... 38

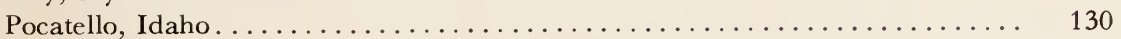

Porcupine . . . . . . . . . . . . . . . . . . . . . . . . . . . 28, 125-126

Potts, Merlin K..................................... 104

Predation:

Coyote correlated with range conditions

Predator control . ................................ 11-16

Predatory mammals, official record of . . . . . . . . . . . . . . . . . 15

Presnall, Clifford C. . . . . . . . ............................ 49

Rabbit, cottontail. ................................ 127

Raven, coyote relationships . . . . . . . . . . . . . . . . . ....... 33-35 
Red Rock Lakes, Moni.

Reese Creek.

$134,135,136,137,138$

Rush, William M

$62,63,68,71,72,73,74,86,87,96,97,98$

Sage Hens

64,99

Sawyer, E. J

Scabies, bighorn

$28,39,47,84$

Sheep, mountain

Shillinger, J. E

13,15

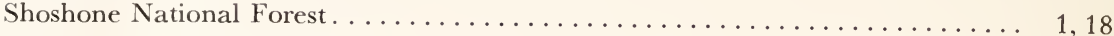

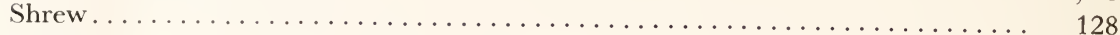

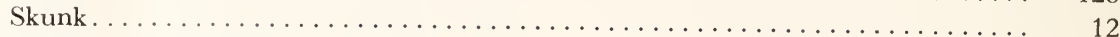

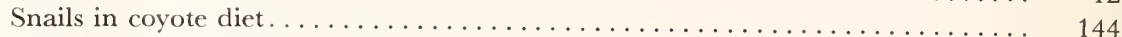

Snakes in coyote diet. . . . . . . . . . . . . . . . . . . . . . . . . . . 144

Sociability, coyotes. .............................. 36-37

Spring activities, antelope ............................. 89-90

Squirrel:

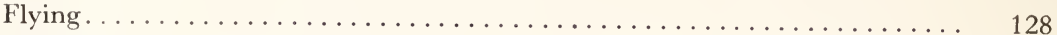

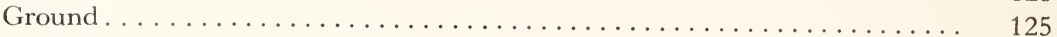

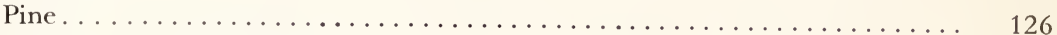

Swan, status of in Yellowstone . . . . . . . . . . . . . . . . . . . . . . . . . . . 134-139

Swan, trumpeter. . . . . . . . . . . . . . . . . . . . . . . 134-139, 147

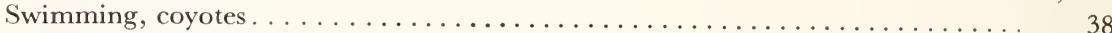

Teton National Forest. . . . . . . . . . . . . . . . . . . . . 56, 124, 126

Tolerance of humans, coyotes . . . . . . . . . . . . . . . . . . . . . . . . . . 38-39

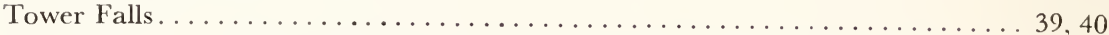
$58,61,67,70,73,74,82,89,93,96,98,103,105,111,113,115,119,132$

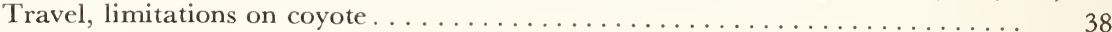

Trumpeter Lake. . . . . . . . . . . . . . . . . . . . . . . . . 135, 137, 138

Vegetable matter in coyote diet. . . . . . . . . . . . . . . . . . . . . 144-145

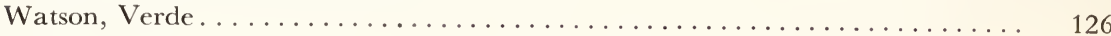

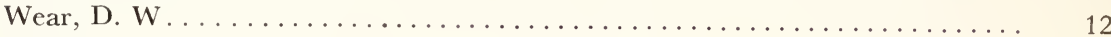

Weasel. ..................................... 128

Welch, Dr. Howard . . . . . . . . . . . . . . . . . . . . . . . . . . 21

Wildlife status, comparison of the primitive and present . . . . . . . . . . . 8 8-10

Wind Cave National Park, S. Dak . . . . . . . . . . . . . . . . . . . . . . . 113

Winter range, deer . . . . . . . . . . . . . . . . . . . . . . . . . . 58

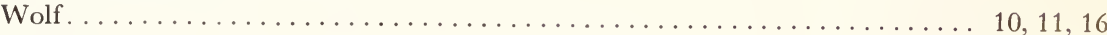

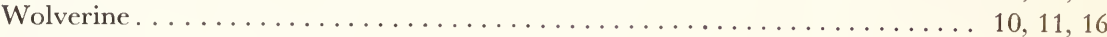

Woodrats......................................... 128

Yellowstone River............662, 63, 64, 67, 68, 69, 70, 71, 72, 73,

$74,75,76,78,81,85,103,105,107,115,116,127,132,133,136$

Young, S. B. M 
$$
\text { . }
$$ 
309 


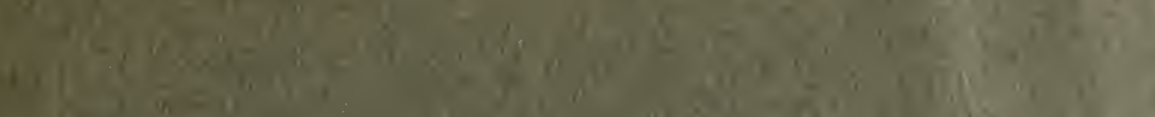

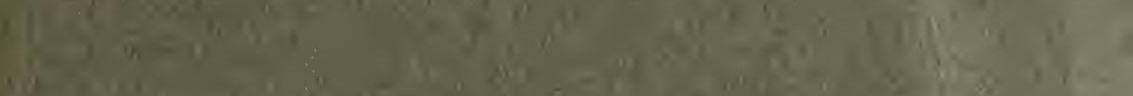

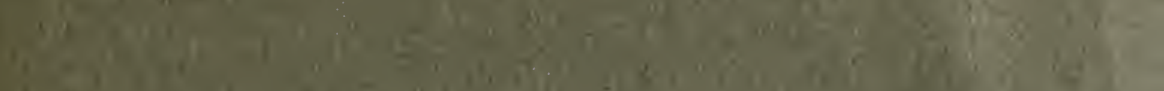

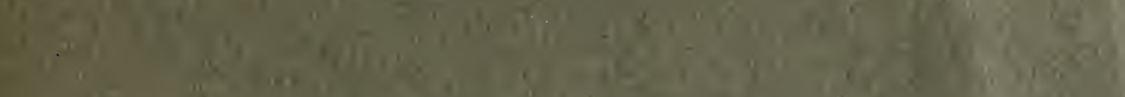

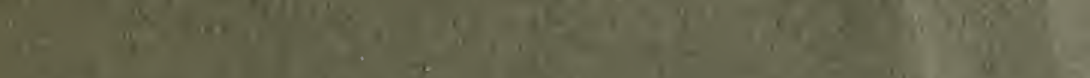

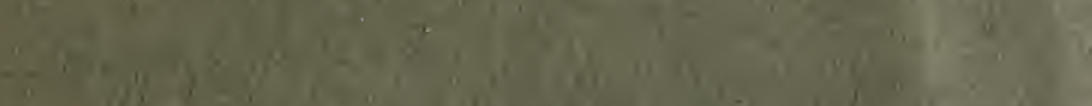

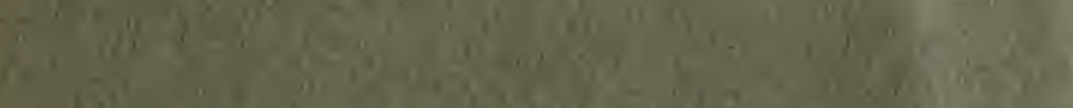

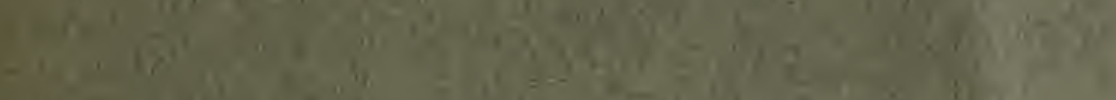

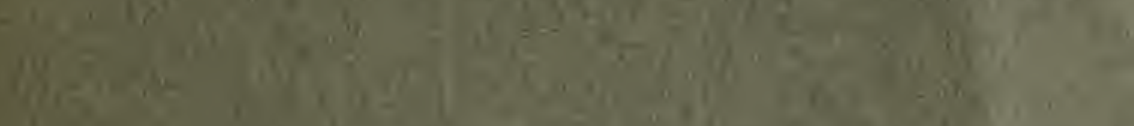
(1)

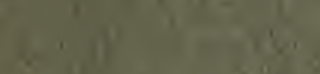

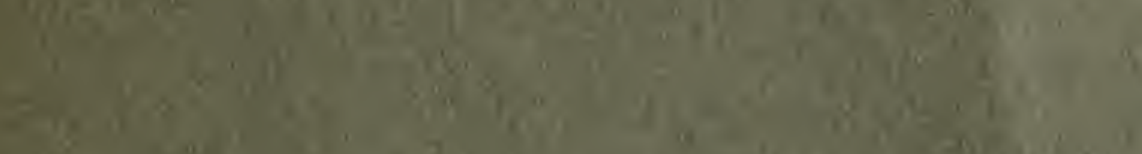

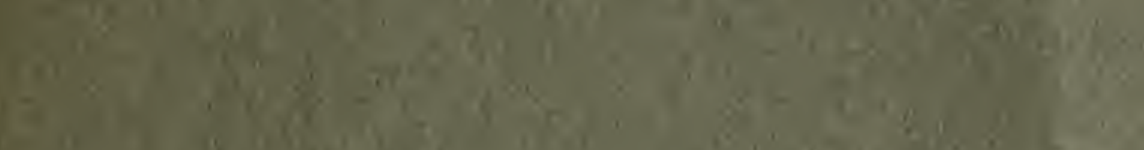

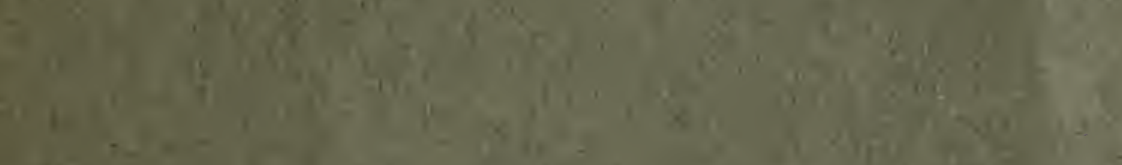

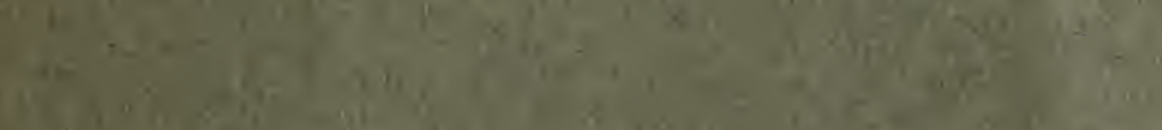
a.

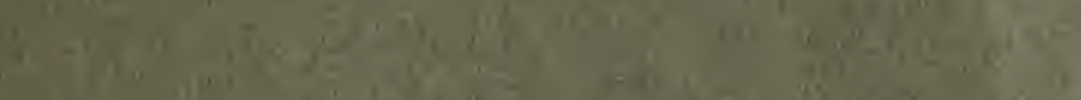

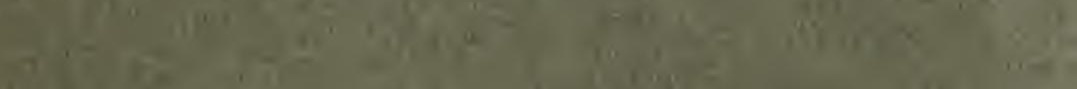

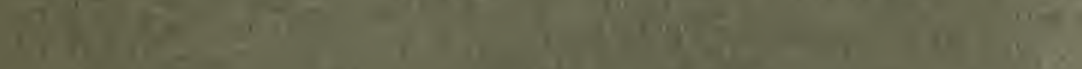
S.

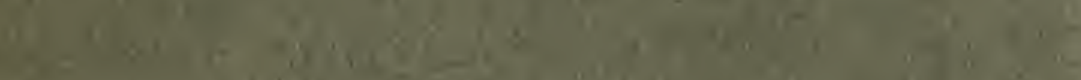

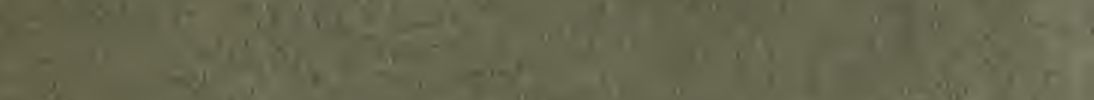

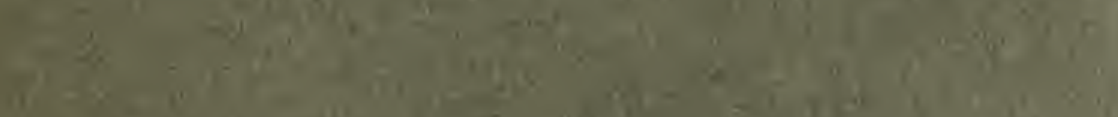

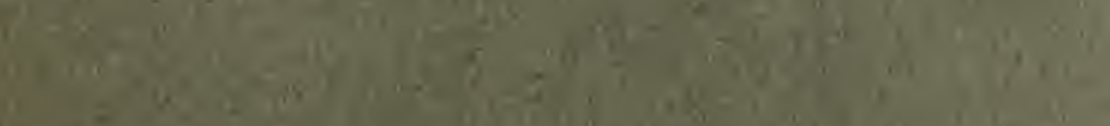

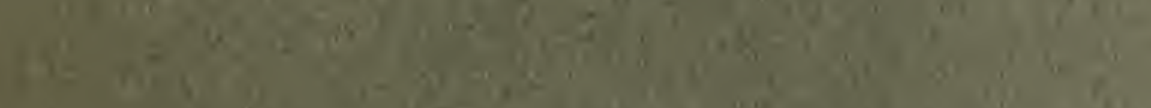

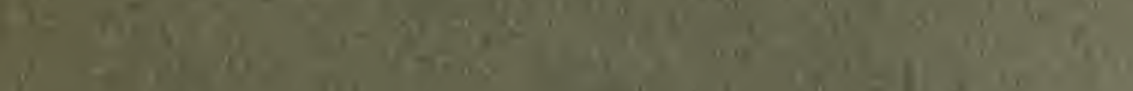

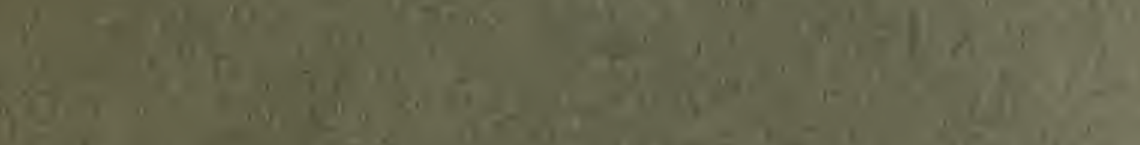

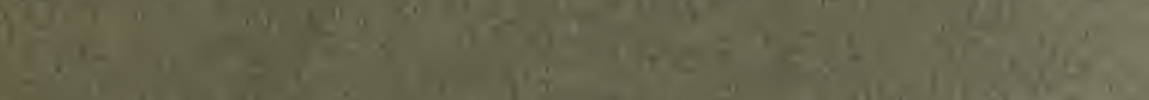

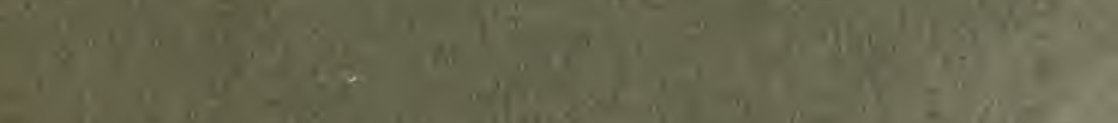

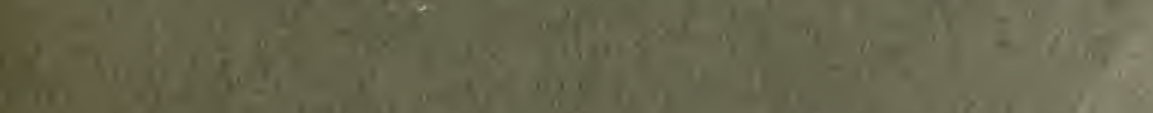
-

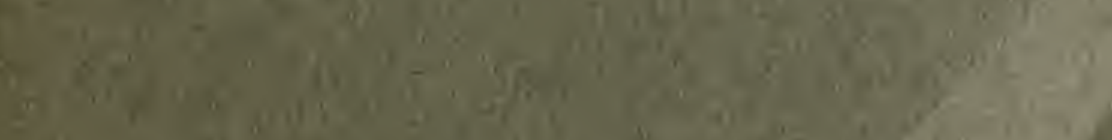

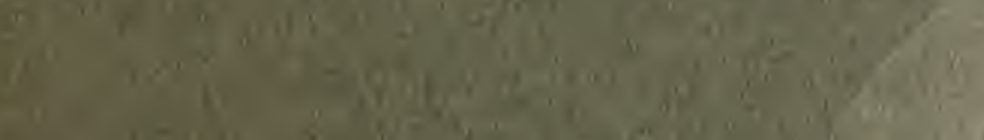

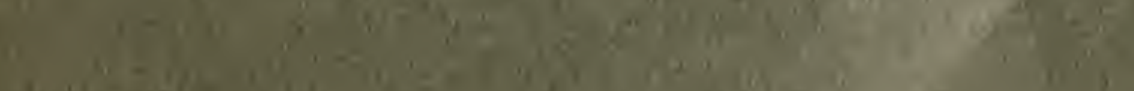

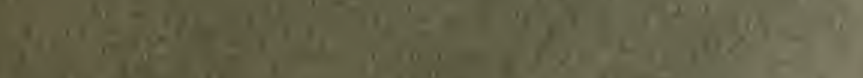


